\title{
On the Fauna and Bottom-Deposits near the Thirty- Fathom Line from the Eddystone Grounds to Start Point.
}

\author{
By \\ E. J. Allen, B.Sc. \\ Director of the Plymouth Laboratory. \\ With Charts I. to XVI.
}

INDEX OF CONTENTS.

SECTION

I. Introduction .

II. The Causes which Influence the Distribution of Life on the Sea-bottom . $\quad 368$

III. The Physical Conditions prevailing on the Grounds investigated . . 374

IV. The Bottom-deposits . . . . . . 377

Determination of the Amount of Carbonate of Lime in the samples of Bottom-deposit, and Description of their Geological Features. By

R. H. Worth . . . . . . . 381

V. Description of the Grounds investigated ․ $\quad$. $\quad . \quad$. 387

VL. The Distribution of Particular Species on the Grounds under investigation . 440

VII. General Considerations-

Tables

1. The Association of Species with one another . . . . 514

2. Geographical Distribution . $\quad . \quad$. 519

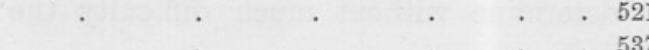

\section{SECTION I.}

INTRODUCTION.

THE investigation described in the present paper was commenced in 1895 , with the aid of a grant of $£ 100$ from the Government Grant Committee of the Royal Society to meet the expenses of boat-hire, and a further grant of $£ 25$ has been made by the Society to assist in the production of the charts by which the paper is illustrated. The object of the investigation has been to gain an accurate knowledge of the distribution of the fauna on the sea-bottom over a continuous area, in order to ascertain and where possible to explain the changes which take place in the animal population when the nature of the bottomdeposit changes. At the same time it was hoped that fresh light would be thrown upon the general question of the distribution of life on the sea-bottom and the principles upon which it depends. It appeared that an investigation of this character gave promise of serving the NEW SERIES,-VOL. v. No. 4. JUNE, 1899. 
double purpose for which the Marine Biological Association was founded, namely, to increase our scientific knowledge of marine animals, and to obtain information having a direct bearing upon problems connected with sea-fisheries. It does not, I think, require any elaborate argument to demonstrate what is brought out clearly in detail in the present report, that the inter-relations between the different animals living in one neighbourhood are so intimate and complex that one cannot hope to understand the natural history of any particular group, such as the fishes, without a knowledge of the whole fauna of which that group forms a part.

Since the principal object of the investigation was to study the relation of the fauna to the bottom-deposit, the area selected for examination was so chosen that the general physical conditions prevailing over the whole of it were uniform, and showed no very marked differences in any feature beyond the changes in the nature of the deposits. The hauls were all made at nearly similar depths, the thirtyfathom line being roughly followed from the Eddystone to Start Point. (See Charts I.-XVI.) Probably the only variable factor which is of any importance at all, in addition to the bottom-deposit, is the amount of disturbance of the bottom water due to the action of waves, which is discussed on p. 375 .

On the western portion of the area the Eddystone Lighthouse, standing as it does upon a reef which rises abruptly with water of thirty fathoms depth all round it, forms a valuable landmark, and enables one to determine without much difficulty the positions of the different stations.

The instrument used in making the collections has been for the most part an ordinary naturalist's dredge, the mouth of which was from $2 \mathrm{ft}$. 6 in. to $3 \mathrm{ft}$. long and 6 to 8 inches deep. On the finer grounds a small otter-trawl and a small beam-trawl ( $27 \mathrm{ft}$. beam) have also been employed. For obtaining actual samples of the bottom-deposits a dredge fitted with a canvas bag inside the ordinary net was used.

About 100 hauls of the dredge or trawl were made altogether, and so far as practicable every species captured was identified and recorded, note being made of its relative abundance, and in the case of fixed species, of the objects to which the specimens were generally attached. It was afterwards found possible to group together many of these hauls, which having been made close to one another showed a similar fauna and bottom-deposit, and these groups have been called grounds. In all eighteen grounds have been recognised.

As already stated, the investigation was commenced in 1895, and it was continued each year till 1898, the hauls having been made at different seasons, but for the most part during the summer, At these 
depths there appears to be little change in the fauna at different times of the year, excepting in the case of the migratory fishes.

In the identification of the species I have received very great assistance from my colleagues, as well as from many naturalists who have from time to time worked in the Laboratory, and without this assistance it would have been impossible to have attempted to give so full an account of the fauna of the grounds as I am now able to do. I would therefore express my great indebtedness to Prof. Weldon, Messrs. W. Garstang, E. W. L. Holt, T. V. Hodgson, E. T. Browne, W. I. Beaumont, T. H. Riches, and T. H. Taylor for the help which has been so readily given. The particular groups in which each naturalist has assisted will be found mentioned in Section VI. It must be understood, however, that the responsibility for the statement that a species occurs upon any particular ground is in all cases my own.

My thanks are also due to Mr. R. H. Worth for the geological examination of the samples of bottom-deposits, and for the determination of the amounts of carbonate of lime which they contain. Mr. Worth's principal contribution will be found at page 381: others are enclosed in square brackets, and are followed by his initials.

With regard to the names adopted for the different species, my one object has been to make my meaning understood as readily as possible. For most of the groups therefore some standard monograph has been made use of, the name of which is stated in each case, and the nomenclature there given has been employed. In a few cases old and wellestablished names have been retained in place of later but less known ones.

It will, I think, be clear to anyone studying the results of this investigation that information of great value would result from a comparison of the faunas of these grounds with those found in similar situations around the British coasts. Although a great deal of dredging has been done, very little information has as yet been published in a form available for making such comparisons, and as will be again pointed out (see p. 377), the accounts of the nature and texture of the bottom-deposit require to be much more definite and detailed than those which have generally been given.

Even when one seeks for knowledge of the true centre of distribution of a species, either of its geographical or of its bathymetric distribution, it is remarkable in how few instances this can be ascertained from the published accounts. If we are ever to obtain an accurate knowledge of the adaptation of species to their environment they must be studied at their centres of distribution, in those localities where they are exceptionally abundant, for it is there that the species is kept true, and it is to the conditions there prevailing that the species is most perfectly 
adapted. So much attention has in the past been devoted to the rarer species occurring in any district that the exact conditions under which the common and prevailing forms exist have often received but little attention. Yet the fact that a species is rare in any locality no doubt in most cases means that it is only imperfectly adapted to the conditions there prevailing, and that if the locality were cut off from communication with the real centre of distribution the species would soon cease to exist in it. Illustrations of this could be almost indefinitely multiplied. One case in point is referred to in some detail on p. 473.

It is clear, therefore, that much yet remains to be done all round our coasts in the way of dredging work. A number of detailed surveys in the different districts and in water of different depths is what is really required. Continuous areas should where possible be examined, samples of the bottom-deposits obtained, and all the physical conditions observed. The nature of the fauna should in each case be described in such a way that the common and characteristic species are clearly indicated and given due prominence, and the inter-relations of the different species pointed out. Special attention should be directed to all spots where any one species is exceptionally plentiful, in order to ascertain as exactly as possible the conditions under which it is best able to flourish.

\section{SeCtion II.}

\section{THE CAUSES WHICH INFLUENCE THE DISTRIBUTION OF LIFE ON THE SEA-BOTTOM.}

In this section I propose to give a brief summary of some of the more important causes influencing the distribution of the animals and plants which live on the sea-bottom, as it will be necessary to constantly bear these causes in mind in considering the nature of the fauna on the various grounds to be described. This summary is based largely on the writings of Forbes, Gwyn Jeffreys, Wyville Thompson, Norman, Berthold, Herdman, M'Intosh, Petersen, and Walther.

The definite distribution of animals and plants in the sea, as on the land, is due to causes some of which are obscure, whilst others, and perhaps the most important ones, are sufficiently obvious. They may, as a matter of convenience, be divided into two classes, the physical causes and the biological causes. The physical causes are the result of those physical conditions which immediately affect the life of the individual members of a species. The biological causes include, in addition to such as are due to the structure and activity of the 
organism itself, all those influences to which a species is subjected in consequence of the existence at the same time of other living organisms. Such influences may be spoken of as the result of the external biological conditions to which the species is subjected. In ultimate analysis, however, the external biological conditions affecting the distribution of a species in any locality are themselves largely, if not entirely, due to physical conditions acting in the same or in neighbouring localities.

Since the assemblage of animals and plants forming the fauna and flora of any particular area is merely a collection of a number of individual species, the causes determining its nature will be the same as those which determine the distribution of species. In the present paper we are more particularly concerned with the distribution of a portion of the bottom fauna and flora of the sea, of those organisms which live in intimate relation with the bottom-deposit and are captured by the use of the naturalist's dredge or of the trawl.

\section{Physical Conditions.}

Those physical conditions, the variations of which influence the life of bottom-living species, are capable of definite statement, and for the most part of accurate measurement. They are-

1. The constitution of the sea-water.

2. The nature of the bottom-deposit.

3. The movements of the water, due to

(a) wave action,

(b) currents,

(c) tides.

4. The temperature of the sea-water.

5. The pressure, varying with the depth of water, to which the organisms are exposed.

6. The amount of light which penetrates to the sea-bottom.

1. The Constitution of the Sea-water. Variations in the constitution of the sea-water of sufficient importance to have any marked effect upon the bottom-living animals and plants are only met with in the neighbourhood of the land. These variations are (1) the addition of fresh-water, indicated by a lowering of density, which is the result of the land-rainfall; (2) the presence of soluble substances derived from the drainage of the land; (3) the presence of solid substances in suspension either brought down directly by the land-water, or stirred up by the action of waves on the coast and in shallow parts of the sea, and (4) in all probability the amount of oxygen and carbonic acid dissolved in the sea-water. 
Of these four variable factors the second, the presence of soluble substances derived from the drainage of the land, has never, so far as I am aware, received any attention, although in many localities, especially in enclosed estuaries, it is probably of considerable importance in influencing the distribution of animal and plant life.

The incursion of fresh-water is a factor which is liable to great variation. At times of exceptional flood the influence of a river will be felt at a much greater distance from shore than at other times. In considering the physical conditions of any particular ground it is necessary to bear this in mind, and to know whether it is or is not subject to such periodic incursions of water of low density at regular or irregular intervals. It is a well-known fact that marine animals are liable to be injured by a sudden change in the density of the water of a much smaller amount than that to which they can quite well become accustomed, provided the change takes place gradually.

2. The Nature of the Bottom-deposit. Since the time of the earliest marine naturalists it has been fully recognised that one of the principal factors in determining the distribution of marine animals and plants is the nature of the bottom-deposit or substratum upon which they live.

The nature of the substratum varies both as to the kind of material of which it is composed and as to the texture of that material. The kind of material forming the bottom-deposit may be either inorganic, when it varies with the geological formation of the particular locality, or it may be organic, consisting of the skeletal remains of marine organisms, in which case it varies according to the fauna of the locality. Deposits composed almost entirely of organic remains have been termed neritic deposits by Herdman. The texture of the bottom-deposit varies from solid rock or large stones to gravel, sand, and the finest mud. Amongst marine animals and plants, especially amongst the former, a great variety of adaptations are found for fixing, for boring, for burrowing, and for locomotion, specially suited to the particular kind of bottom upon which the organism generally lives. In very few cases, however, have the different kinds of bottom-deposit, upon which a particular species can live, been accurately ascertained, and one of the results of such investigations as that detailed in the present report is to obtain additional evidence on such questions.

3. The Movements of the Water. (a) Wave action. The important influence exerted by the action of the waves on animals and plants living between tide-marks, or in water of only a few fathoms depth, has always been recognised by naturalists, and many of the adaptations of structure and habit, by means of which this action is combated, have been pointed out. It was not, however, until the appearance of Hunt's paper (No. 54) on the influence of wave currents that the atten- 
tion of naturalists was directed to the fact that this factor was in all probability of great importance to animals living even at such depths as 30 or 40 fathoms, at any rate in those seas which are subject to large waves and to strong tidal currents. Even since the publication of this suggestive paper the subject does not appear to have received the attention which it deserves. Hunt bases his conclusions not only upon his own observations of objects trawled from a depth of 40 fathoms in the English Channel, but he publishes a letter from Sir George Stokes, in which the subject is treated from a mathematical standpoint, the conclusions being such as to entirely agree with those which had been drawn from observation. Hunt points out in detail some of the adaptations of animals living in shallow water to resist this movement of the waves.*

(b) Currents. From the point of view of the distribution of bottomliving marine organisms currents are important (1) as the bearers of a large and important food-supply; (2) as a means of distribution of the larvæ of many animals and the spores of plants; (3) as influencing in many places the nature of the bottom-deposit; (4) from the alterations which they may produce in the density and temperature of the water, and (5) from their power of sweeping away such organisms as are insufficiently fixed.

(c) Tides. It would be beyond the scope of the present paper to enter into a discussion of the peculiar conditions found within the belt of sea-coast which is alternately exposed to the air and covered by the sea with the ebb and flow of the tide. The highly special character of the fauna and flora due to this cause is well known, and has often been described.

The currents produced in shallow seas, such as those around the English coasts, by the action of the tidal wave, influence the bottomfauna in the same ways as do currents due to other causes. $\dagger$ These have already been sufficiently indicated, but in the case of the tidal current one important difference must be noted. In the great majority of instances the tidal current runs alternately in opposite directions, and it would not therefore be likely to bring such an abundant foodsupply as a steady current progressing at the same rate, nor would it tend to distribute larvæ over a very large area.

This equal alternation of the tidal current is often greatly modified in the immediate neighbourhood of the coast, especially where bays and inlets of the sea abound. In such localities the current may run for a much longer time in one direction than in the other.

* For a further discussion of this subject see pp. 375 and 457 .

+ The strength of the bottom tidal current, as indeed of all bottom currents, in the seas around the British Isles is a subject about which definite information is very much needed. 
4. Temperature of the Sea-water. There seems to be some difference of opinion amongst recent writers as to the extent to which temperature is a determining cause in the distribution of marine species.

The following general principles appear to be beyond dispute.

Change of temperature, having regard both to the amount of the change and to the rapidity with which the change takes place, is of greater importance in its influence upon marine life than the actual degree of temperature, though at the same time the latter must not be considered to be without effect.

For each species there is a maximum rate of change of temperature which the species is able to endure without injury, and this rate of change differs greatly for different species.

Each species is specially adapted to flourish within a particular range of temperature, which differs both in actual degree and in extent of range for different species.

It also seems probable that, provided the change takes place sufficiently slowly, the particular range of temperature to which a species is adapted may alter, and a race of the species may arise adapted to a temperature range different to that of the species in general. Whether or not selection plays a part in the formation of such races it is impossible in the present state of knowledge to say.

5. Pressure. The range of many species in depth is very great, so that it is evident-and the fact has been sufficiently recognised since the time of Forbes and Gwyn Jeffreys-that pressure in itself has little influence on the distribution of marine animals, unless the differences of pressure are very great indeed.

6. The Amount of Light which penetrates to the Sea-bottom. The extent to which light penetrates the sea-water is one of the most important factors in determining the distribution of marine life, since on it depends the existence of the plant life upon which animals ultimately depend for their food supply.

Berthold has shown that different species of marine algæ require different light-intensities in order to flourish at their best. Some grow only where the light is very strong, the majority, however, attain their maximum development in situations which are to some extent shaded, or in which the intensity of the light is modified by the depth of water through which it has to pass.

The amount of light which penetrates the sea-water and becomes available for bringing about the assimilation of plants depends, in the first place, upon the amount of light which strikes the surface of the sea, and will vary therefore with the particular climate and meteorological conditions prevailing in each locality. The depth at which marine algæ will be found will be greater in localities where the sky 
remains clear and the light of the sun intense for long periods, than in those where the opposite conditions prevail. The clearness of the water, which depends upon the amount of solid matter in suspension, will also be a factor of importance.

In addition to the indirect effect of light upon the distribution of animal life in the sea, owing to the dependence of the latter upon plant life, there is also a direct effect, which, however, appears to be of importance only within somewhat wide limits. The distribution of those animals which seek their food chiefly by the aid of sight will evidently be limited by the amount of light which penetrates, whilst the safety of those which serve them as food will be correspondingly increased as the amount of light diminishes.

\section{External Biological Conditions.}

The external biological conditions influencing the distribution of any bottom-living organism (animal or plant), due to the existence at the same time of other living organisms, are often of a complicated nature.

1. One organism may exert an advantageous influence upon another.

(a) By serving as its food-supply;

(b) By serving as a fixed base to which it may attach itself ;

(c) By serving as a movable base, and thus extending the area over which a fixed organism can collect its food-supply;

(d) By bringing supplies of food to the other organism as well as to itself, either by setting up a current, or in some other way;

(e) By affording the other organism means of protection or concealment from its enemies.

2. One organism may exert a disadvantageous influence upon another.

(a) By preying upon it;

(b) By fixing upon it in such a way as to destroy it;

(c) As a competitor for a limited food-supply, or for a limited amount of fixing space.

3. The biological conditions by which the organisms on any particular patch of ground are influenced depend not only upon the organisms living on that ground itself, but also upon the nature and abundance of the organisms living upon neighbouring grounds.

The meaning of the latter statement can perhaps be best explained by supposing that a particular patch of ground could be cleared of all the organisms living upon it, and then allowed to remain until it had acquired a new population. The nature of this new population would depend upon the physical conditions of the ground, upon the nature of the larval animals which were brought to it by the moving water 
above, and upon the wandering animals which entered it from other grounds. The nature of the larval forms would depend upon the nature of the grounds over which the water had previously passed, and it would appear that the supply of larvæ from grounds in the immediate neighbourhood would be much greater than that from those which were more distant. In this connection the tidal current, running alternately in opposite directions, will evidently be an important factor. It will be shown in the present report that in many cases the nature of the fauna at a particular spot is distinctly influenced by the fauna of grounds in the immediate neighbourhood.

The principle just discussed may be extended to the fauna of any particular district, which will be influenced by the nature of the fauna in surrounding districts. The fact, which has long been well known, that the fauna in the western portion of the Channel is composed of a mixture of northern and southern species is, to some extent, a result of the principle enunciated.

\section{SECTION III.}

\section{THE PHYSICAL CONDITIONS PREVAILING ON THE GROUNDS INVESTIGATED.}

THE grounds have been so chosen that, with the exception of changes in the nature of the bottom-deposit, the differences in their physical conditions are probably only slight and not of great importance. Under the present heading those conditions, which are nearly the same for all the grounds, will be described, whilst the nature of the changes which the bottom-deposit undergoes will be reserved for an independent section.

The grounds lie in the immediate neighbourhood of the 30 -fathom line (Charts I. to XVI.), all of them being between the 25- and 35fathom lines. In the neighbourhood of the Eddystone the 30 -fathom line is from eight to nine miles distant from the coast, and within about a mile of the exposed Eddystone rocks. Near Bolt Head and Prawle Point, on the other hand, it approaches to within $1 \frac{1}{4}$ miles of the shore.

The Composition of the Water. The density of the water on all the grounds may be taken, for the purposes of the present inquiry, to be that of normal Atlantic water, any variation from this figure being so small as to be without importance in influencing the distribution of the bottom fauna.

This appears to be the case even for the Bolt Head and Prawle Grounds, which lie close to the entrance of the Salcombe estuary, as is 
shown by the observations made by Mr. H. N. Dickson (No. 21, pp. 166-169) in 1891. Dickson's stations I. and XV. are sufficiently near to be of value.

Station I. Bolt Head N.E. by E. $1 \frac{1}{2}$ miles. June 15th, 1891.

$$
\begin{array}{lll}
\text { Density }\left({ }_{4} \mathrm{~S}_{15 \cdot 56}\right) \text {. } & \text { Surface } & 1.02601 \\
& 19 \text { fathoms } & 1.02599
\end{array}
$$

Station XV. Bolt Head N.N.E. $1 \frac{1}{2}$ miles. June 17th, 1891.

$$
\text { Density }\left({ }_{4} \mathrm{~S}_{15 \cdot 56}\right) \text {. Surface } 1.02598
$$

19 fathoms 1.02602

In November, 1891, and March, 1892, samples were also taken by Dickson at the above Station I., as well as at other stations in various parts of the Channel, and he reports (No. 21, p. 273) that "the examination of these samples has shown that the water over the area under consideration is normal Atlantic water throughout."

No accurate data can be given as to the amount of solid matter in suspension in the water at various times, as no attempts have been made either to determine this directly or to measure the degree of transparency of the water. It is possible, owing to the nearer proximity of the coast in the neighbourhood of Prawle Point, that the water there at the 30 -fathom line may at times be somewhat more muddy than that in the neighbourhood of the Eddystone.

The Movements of the Water. 1. Wave Action. No satisfactory method has yet been devised for measuring directly the amount of wave action at various depths. There is, however, considerable evidence to show that a certain amount makes itself felt on the grounds under consideration, and that although the amount is small it is appreciably different on the different grounds.

That the amount of wave action extending to the bottom is generally slight is shown by the abundance of the hydroids Antennularia antennina and Aglaophenia myriophyllum, which fix themselves in the sand or fine gravel by a felt-work of root-fibres in such a way that they would certainly be torn up by any violent movement of the water, and on the fine sand grounds Cellaria is abundant fixed in a similar way. On the gravel also to the west and south-west of the Eddystone the ascidian Polycarpa varians (Heller) is very plentiful, and is generally attached only to the gravel itself, for nearly all the specimens which come up in the dredge are found to have their bases covered with pieces of gravel to which they are firmly fixed.

The distribution of Alcyonium digitatum (see p. 457), on the other hand, seems to indicate that the amount of movement of the bottom water is appreciably less on the grounds where the depth is greater than 33 fathoms than it is upon those from 28 to 33 fathoms. 
The evidence for considerable wave action is strongest on Grounds XIV. and XVI., immediately to the west of the Eddystone reef, where it is probably increased by the rebound of the Atlantic swells from the rocks. On Ground XVI. (see Charts) the bottom-deposit is a shell gravel, which is remarkably clean and free from silt, ${ }^{*}$ as will be seen from the figures in Table II., p. 525, which shows the texture of the samples taken from the different grounds. There is also on this ground an almost entire absence of such species as fix directly to the bottomdeposit.

The sample of the bottom-deposit on Ground XIV. (haul 85) is unique amongst all the samples obtained, in having the fine sand grains rounded and highly polished (see p. 385), and on this ground the number of hydroids is also very small.

There is evidence (see p. 425) that Ground XIII., which lies southeast of the reef, is more sheltered from wave disturbance than the grounds to the westward of the Eddystone.

2. Currents and Tides. Practically nothing is at present known as to the strength or even as to the prevailing direction of the bottom currents of the Channel. It is well known, however, that the surface currents are especially strong around the various headlands, and it is probable that these will still be felt on the bottom. If this be so the currents on the Bolt Head and Prawle Grounds may be more rapid than those in the neighbourhood of the Eddystone.

Temperature. The Laboratory records of bottom temperatures at depths of about 30 fathoms show a range from $7 \cdot 1^{\circ} \mathrm{C}$. $\left(48^{\circ} \mathrm{F}\right.$, March, 1898$)$ to $13.9^{\circ} \mathrm{C}$. $\left(57 \cdot 1^{\circ} \mathrm{F}\right.$., Nov. 17 th, 1898). The records at this depth are not, however, very numerous, and the above observations probably do not quite represent the maximum and minimum temperatures. The temperature changes very slowly, generally not more than $1^{\circ} \mathrm{C}$. in a month, and the total yearly range may be safely put at about $7^{\circ}$ or $8^{\circ} \mathrm{C}$.

Pressure. The depth of water on all the grounds varies only from 25 to 35 fathoms, which represents a difference of pressure too slight to affect the bottom animals.

Amount of light which penetrates. This is sufficient only for the lowest forms of vegetable life, such as diatoms, coccoliths, etc. None of the branched red or brown sea-weeds are found on any of the grounds.

\footnotetext{
* Wave action in itself would not of course be able to remove silt which had been deposited; it would, however, tend to keep the silt in suspension, so that it would be carried away by the prevailing currents.
} 


\section{Section IV.}

\section{THE BOTTOM-DEPOSITS.}

THE question of the changes in the nature of the fauna which take place in shallow waters with changes in the character of the bottom-deposit is one to which considerable attention has recently been paid. More especially Marion (No. 74) in the Gulf of Marseilles, Petersen (No. 95) in the Kattegat, Herdman (Nos. 40-44) in the Irish Sea, and Pruvot (No. 98) in the Mediterranean and in Brittany have dealt specially with the subject. At the instigation of these naturalists chemical analyses of the bottom-deposits have been made and their geological characters have been described.

In considering the relation between the nature of the bottom-deposit and the fauna living upon it, the factor which appears to be of primary importance is the texture of the deposit rather than its geological character. This is fully recognised by the authors named, and it is a point to which the attention of marine naturalists has always been directed.

The terms rock, stone, gravel, coral or nullipore, shell, sand, fine sand, mud, muddy gravel, muddy sand, etc., have generally been used to express differences in the nature and texture of the deposits. These designations are adopted from navigators, and are the terms used on Admiralty and other charts to express the nature of the material brought up on the tallow placed for the purpose at the end of the ordinary sounding-lead. But a very slight study of the accounts of dredgings given by various authors is sufficient to show that these terms are used in very different senses by different individuals. The term sand especially seems to be employed in a very broad sense to include deposits having a wide range of texture. Several of the other terms are also much confused.

After the present investigation had proceeded for some time it seemed necessary that an attempt should be made to actually measure the texture of the deposits found in different places, so that accurate and consistent descriptions might be given. The readiest method of doing this is to separate the particles of different sizes by means of a series of sieves of standard meshes, and then to determine the percentage of material of each size in the sample. Since my results were obtained I have found that three or four of Petersen's samples were examined in the same way, though, unfortunately, he does not give the numbers of the hauls from which they were obtained, and it is impossible, therefore, to discover the fauna connected with them. 
The method of procedure which has been adopted will now be described.

Obtaining the Sample. In order to get a correct idea of the nature of the deposit it is not sufficient to take a sample of so much of it as happens to come up in the ordinary dredge. Samples obtained in this way have lost much of the finer portions of the deposit, and generally give a very incorrect idea of its nature. The samples, the composition of which is here described, have always been taken with a moderatesized dredge (about $2 \mathrm{ft} .8 \mathrm{in}$. long), ${ }^{*}$ fitted with a bag of stout canvas inside the ordinary net. At the end of a haul of the ordinary dredge it was our custom to steam back a little way over our course and then work this dredge with the canvas bag, leaving it down only for two or three minutes. In this way a good sample of the deposit was obtained, and the haul often yielded interesting species not obtained in the usual way of dredging.

Examination of Samples for Texture. The samples were brought back to the Laboratory, and for their examination a series of sieves made of zinc and with perforated zinc bottoms was employed, through which the samples were washed. The sieves had a diameter of 15 centimetres and six of them were used, the sizes of the (circular) perforations being $15 \mathrm{~mm}$., $5 \mathrm{~mm}$., $2.5 \mathrm{~mm}$., $1.5 \mathrm{~mm}$., $1 \mathrm{~mm}$., and $0.5 \mathrm{~mm} . \dagger$ The material passing through the $0.5 \mathrm{~mm}$. sieve was further subdivided into two parts, one of which was regarded as fine sand and the other as silt. This separation was made by stirring the material up with a considerable quantity of sea-water, allowing it to settle for one minute, and then pouring the water off. The process was generally repeated a second time, the material remaining in suspension being regarded as silt, whilst that which settled in one minute was regarded as fine sand.

In this way eight grades of material were obtained altogether, and it was found that these could conveniently be distinguished by the following nomenclature:-

I. Stones. All inorganic material which will not pass through $15 \mathrm{~mm}$. sieve.

II. Coarse Gravel. Material left on $5 \mathrm{~mm}$. sieve.

III. Medium Gravel ", " $2.5 \mathrm{~mm}$. ,

IV. Fine Gravel " " $1.5 \mathrm{~mm}$. "

V. Coarse Sand " " $1 \mathrm{~mm}$. "

VI. Medium Sand ", " $0.5 \mathrm{~mm}$. "

* The size of the dredge is important, as a smaller and lighter one would probably not dig so deeply into the deposit. A strong net is retained outside the canvas bag in order to take some of the strain when the dredge is brought up.

+ Perforated zinc with holes of these diameters can be obtained from Messrs. J. Staniar \& Co., Manchester Wire Works, Manchester. 
VII. Fine Sand. Material which passes through $0.5 \mathrm{~mm}$. sieve and when stirred up with sea-water settles in one minute.

VIII. Silt. Remains in suspension at the end of one minute.

The designations here adopted seem to agree very well with the ideas generally connected with the respective terms, and it would be a great advantage if these terms could in future be used in the exact senses proposed.

In determining the texture of a sample by the use of a series of sieves it is necessary, in order to obtain constant results, that a considerable quantity of material be examined, especially in the case of coarse and mixed deposits. My practice was to sieve the quantity which was contained in a bottle of about 800 cc. capacity.

After trials of various methods the following was adopted as the readiest and most convenient way of obtaining satisfactory results. The finest sieve was placed in a vessel somewhat larger and deeper than itself, so large in fact that the sieve could be conveniently worked about with the hand. Sea-water was then poured into the surrounding vessel until the sieve, standing in it, was nearly full. Small portions of the sample were placed in the sieve and worked about until all the fine sand and silt were washed out. In the case of very muddy samples the process was repeated in a second quantity of water. The portion remaining on the sieve was washed through the other five sieves successively in a similar way, commencing with that of largest mesh.

The mixture of fine sand and silt was separated by stirring it up well in the sea-water, allowing it to stand for one minute, and then pouring the water off. Where two washing waters had been used, the second, with its contents, was poured on to the first sample of fine sand, the whole stirred up again, left to stand one minute, and the water poured off. The water in which the silt was suspended was allowed to settle for at least twenty-four hours and the clear portion then drawn off. The remainder was passed through a weighed filter paper and the silt collected.

The samples of gravel and sand on the various sieves and of silt on the filter paper were all dried at a low temperature and weighed, the results being expressed as percentages of the total weight. The textures of the various samples examined are shown in Table II., p. 525 . One of the most curious features brought out by this method of examination of the texture of the bottom-deposits is the fact that nearly every sample of the coarser deposits is composed of a mixture of coarse gravel and fine sand or mud, material of intermediate texture being present in small quantity only. Thus sample 84 is a mixture of coarse 
gravel ( $47 \cdot 6$ per cent.) with fine sand $(17 \cdot 7$ per cent.), and a little silt ( 2.8 per cent.), the intermediate grades of gravel and sand being small. Sample 103 is a mixture of gravel with mud, the proportion of silt here rising to 17 per cent., with only 10 per cent. of fine sand, the highest percentage of silt in any sample examined from these grounds.

For comparison with the figures in the table $I$ have given in the last column the texture of a sample of fine, sticky mud from Plymouth Sound, which contains 70 per cent. of fine sand to $24 \cdot 4$ per cent. of silt.

The Organic Constituents of the Bottom-deposits. Mr. Worth reports below on the relative amounts of organic carbonate of lime contained in the different samples. The organic constituents from which this carbonate of lime is derived consist, on the grounds under investigation, almost entirely of the remains of molluses, echinoderms, serpulids, and polyzoa, and there is no example on the whole area of a "nullipore" ground. It is especially noticeable in Grades II. and III. that the shell material is composed very largely of entire small shells of lamellibranchs or of fragments of such small shells, and not of broken pieces of large shells. Many of these shells show the clean circular perforation, such as is produced by the boring gasteropods.

Sponge spicules are abundant in the finer grades.

The Silt. Although constituting only a small percentage of the whole material forming the bottom-deposit on the grounds included in the present investigation, the silt is of great importance from the biological point of view, since many animals living on the grounds obtain their food by passing it through the alimentary canal and extracting such nourishment as it contains. The silt from a freshly taken sample of deposit, when shaken up with sea-water, forms a flocculent precipitate, the greater part of which settles fairly rapidly. On the other hand, when shaken up with fresh-water, a great deal of it remains in suspension for a long time, and the water may have a muddy appearance for several days.

Microscopical examination of the fresh silt shows that a very considerable portion of it is of organic origin, and the analysis and examination of dried samples confirm this ( $c f$. p. 386). Diatoms are very numerous as well as foraminifera (for species recognised see p. 442), and Coccoliths are invariably present in very considerable numbers.

Attention has recently been drawn to the presence of Coccoliths in our coastal waters by Joly and Dixon (No. 57), who found them in the precipitate obtained by treating a quantity of sea-water in a centrifugal apparatus revolving at a high rate of speed. They had, however, been found by Behrens (No. 6) in samples of bottom-deposit from the Baltic as long ago as 1873 . 
Coccoliths can be readily obtained in large numbers by shaking up a small quantity of bottom-deposit with sea-water, pouring off the muddy water, and allowing it to settle. I have found them to be much more numerous in samples taken from below 15 fathoms than in those obtained from the shallow waters of Plymouth Sound, although a few can generally be found in the latter. These organisms must now therefore be regarded as very abundant in the sea, and their importance in the economy of many marine animals must be great, since they furnish a source of food-supply containing carbonate of lime.

\section{Determination of the Amount of Carbonate of Lime in the SAMPLES OF BotTOM-DEPOSIT, AND Description OF THEIR Geological features. By R. H. Worth.}

"1. Average Grade of Sample.-The sands and gravels had already been sieved and graded before their examinations for geological purposes and for the determination of carbonate of lime. It appeared evident, however, that as a ready means of determining the relative texture of a whole sample it would be necessary to compress the information contained in the table which gives the percentage of each grade in each sample (Table II., p. 525).

"The method adopted is founded on the determination of the average grade of the whole sample. The figures I., II., III., etc., having reference to grades left in a sieve of $15 \mathrm{~mm}$., $5 \mathrm{~mm}, 2.5 \mathrm{~mm}$., etc., are purely conventional, but may be conveniently adopted for the purpose of shortly stating the average grade of any sample. The actual method followed was to multiply each percentage in the table by the conventional number attached to its grade, add together all the figures so obtained, and divide by 100 ; the result has been described as the 'average grade' of each sample, and affords a ready means of comparing the texture of any two deposits. Close comparison still of necessity requires a reference to the detail on which this average is based. As an instance of the method the determination of the 'average grade' of sample 83 is appended:-

$$
\begin{aligned}
& \text { I. Stones . . . . . } 0.00 \times 1=0.0 \\
& \text { II. Coarse gravel . . . . } 27.9 \times 2=55 \cdot 8 \\
& \text { III. Medium gravel . . . . } 28.3 \times 3=84.9 \\
& \text { IV. Fine gravel . . . . } 14 \cdot 1 \times 4=56 \cdot 4 \\
& \text { V. Coarse sand . . . } 6.0 \times 5=30.0 \\
& \text { VI. Medium sand . . . . . } 7 \cdot 3 \times 6=43.8 \\
& \text { VII. Fine sand . . . . . } 8.3 \times 7=58 \cdot 1 \\
& \text { VIII. Silt . . . . . . . } 8.2 \times 8=65.6 \\
& 394 \cdot 6 \div 100= \\
& 3.946 \text {, the 'average grade' of sample } 83 \text {. }
\end{aligned}
$$


grades $6 \cdot 3$ and $7 \cdot 0$, the lower numbers corresponding to the coarser and the higher to the finer textures.

"Grade VII.- the 'fine sand'-varies considerably in the different samples. Its coarser forms approximate in some few samples to a sand the individual grains of which are none greatly under $5 \mathrm{~mm}$. in diameter. Its finer forms in some samples have but few grains of these dimensions, as compared with a great number of grains approximating to the 'silt.'

" 2. Carbonate of Lime.--Care was taken to ascertain how far any results of chemical determination might be invalidated by the presence of inorganic carbonate of lime in the rock fragments. The result of inquiry proved that practically no lime existed in the rock fragments which was soluble in cold dilute hydrochloric acid. All carbonate of lime so soluble is in these samples of organic origin.

"In the finer grades below III. carbonate of lime was determined by treating each sample with dilute hydrochloric acid, filtering, neutralising the filtrate with ammonia and again filtering, precipitating the lime with ammonium carbonate $\left[\left(\mathrm{NH}_{4}\right)_{2} \mathrm{CO}_{3}\right]$, filtering, washing precipitate, drying and weighing as carbonate of lime.

"In grades I., II., and III. the shells, shell fragments, etc., were picked out by hand and weighed.

"Tables III. and IV., p. 526, give the results thus obtained.

"A feature of these results is the low percentage of $\mathrm{CaCo}_{3}$ in the fine texture deposits, having an average grade of 6.4 to $7 \cdot 0$. In Table V., p. 528, the samples are arranged in order of their average textures and the total percentage of $\mathrm{CaCo}_{3}$ set opposite each sample.

"The coarse samples are not, perhaps, uniformly high in their percentage of carbonate (94 is a notable exception), nor are the fine samples uniformly low, $89 \mathrm{~B}$ and 109 being the exceptions, but on averages the general figure for the fine textures falls much below that for the coarse. Another noticeable fact is that the percentage of carbonate of lime found in the finer sands of each sample shows a distinct tendency to follow the total amount of carbonate of lime present in the gravel and coarse sand of the same samples (again with the exceptions of $89 \mathrm{~B}$ and 109 , which are evidently detrital matter from adjacent shelly grounds).

"This points to the fact that most of the carbonate of lime in the fine sands is detrital matter from shell fragments, etc., in the gravels and coarse sands, and microscopic examination confirms this.

"The percentage of carbonate of lime in the silts is comparatively low, with the exception of silt 109. It apparently follows no definite rule, beyond a mere tendency to be somewhat higher in silts where the whole sample is rich. There is less variation between different samples in the matter of percentage of carbonate of lime in the silts than in any other feature.

"An attempt might be made to explain the poverty of the silts in carbonate by the fact that once shell fragments are ground sufficiently fine to pass into this grade they present so much surface area in proportion to their solid capacity as to fall an easy prey to the solvent action of sea-water. 
“3. Rock Fragments and Sand Grains.-Grades I., II., and III. were examined and the rock fragments identified. Advantage was taken of the search for foraminifera to examine the sand grains in grades VI. and VII., and the residues from the acid solutions after dissolving out the carbonate of lime have also been examined.

"There are three clearly defined geological areas represented by these samples.

"The first, represented by a single dredging only, occurs at 90 (Ground V.), to the north-east of the Eddystone and south of Rame Head. Here the rock fragments are almost entirely Devonian in character, the gravel consisting of fragments of slate and quartz from veins in slate, closely resembling the rocks of Penlee Point. A little Trias occurs.

"The second area covers the whole of the rest of the samples examined from the Eddystone neighbourhood. This may be called the Triassic area. The prevailing rock fragments are the detritus of Triassic rocks; mottled sandstones, red jaspideous sandstones, micaceous sandstones, and drab sandstones. This must be taken as an indication and not an exhaustive definition of the nature of the rocks. In consequence of the presence of these rocks the bottom-deposits contain a great amount of free crystalline silica and a considerable amount of iron. Associated with the Trias are some Devonian rocks, but the amount of these present is comparatively small, rarely rising above 15 per cent. and never reâching 16 per cent. Fragments of the Eddystone gneiss also occur, but in small quantity except in the immediate neighbourhood of the reef.

"The third area is represented by samples 105 and 106 (Ground XVII.) from the neighbourhood of the Bolt. This may be described as the 'Archean Schist' area. The rock fragments are largely derived from mica and chlorite schists, similar to or the same as those forming the promontory of the Bolts. In 105, II., the Archean schists form 78.75 per cent. of the whole rock fragments, Flint pebbles form 12.74 per cent., and Triassic rocks 8.51 per cent. The Prawle Stony Ground (XVIII.) corresponds geologically to 105 .

"Further south, at the point at which 106 was dredged, the Archean falls to 48.90 per cent. and the Flint rises to 40.44 per cent., apparently indicating the proximity of a cretaceous area. Trias is still present as 10.66 per cent.

"These Archean rocks are referred to in 'The Rocks of South-west Devon,' R. N. Worth, Devonshire Association Transactions, 1887, as well as elsewhere in the same Transactions by other writers.

"Briefly stated the geological results are as follows :-

"It is almost certain that the gneiss and granitoid rocks which constitute the summit of the Eddystone reef are restricted in area of exposure to little more than the summit and a portion of the sloping sides of the reef. It is only at 87 that the gneiss preponderates over all other rock constituents in the gravel, and here in 87 , III., it reaches 74.07 per cent. of the total rock constituents. This is on the immediate western fringe of the reef.

"At 85, a little west of 87 , the gneiss forms 25 per cent. of the rock constituents, and at 103, south-east of the reef, it forms 26 per cent. 


\section{ON THE FAUNA AND BOTTOM-DEPOSITS NEAR THE 30-FM. LINE}

"The presence of the Trias is not surprising. The probable existence of submarine Trias between the Lizard and Plymouth had already been suggested by R. N. Worth, who, in 1886, reported the existence of a submarine Triassic outlier, having its centre about ten miles south-east of the Lizard. (Quart. Jour. Geol. Soc., Aug., 1886.)

"But although not altogether unexpected, this Trias of the Eddystone neighbourhood is now reported for the first time, and deserves more detailed and lengthy description than would be appropriate to the objects of the present investigation. For present purposes it will be sufficient to state that the nearest shore exposures of rocks of similar formation occur at Oddicombe Beach, St. Mary Church, again at a point immediately to the west of the Bolt, and lastly, on either shore of Plymouth Sound, in Cawsand Bay and to the south of Bovisand respectively.

"The presence of the iron of the Trias has apparently had its effect on the foraminifera, for some of the Miliolina especially present an unusually ferruginous appearance.

"Among the Eddystone gravels were found scattered fragments of amorphous silica, insufficient in number or weight to affect numerical results. These were mostly regarded as Triassic before the Bolt examples had been examined. Such an identification was justified by the known existence of veins of calcedony in the submarine Trias off the Lizard. Their absolute identification is still problematic. Not so, however, with the flint gravel from the Bolt district. This, although much affected by the solvent action of the sea-water, is still recognisable as flint, and possibly more exact information may on further examination be derived from some of the apparent fossils which have survived the solvent action of the water. It is interesting to note the extent to which this solution has been carried. The outside of practically every flint pebble has been converted by it into a microscopic honeycomb, and only the larger fragments have any core of unaffected silica remaining. The crystalline quartz grains of the Trias, on the other hand, have resisted the chemical action of the water.

"The sands are interesting as giving evidence of the relative degree to which wave action has affected the sea-bottom. It may seem a truism to suggest that a fine-grade sample may owe its fineness of textures either to the presence of a large quantity of fine sand or to the absence of all but a small proportion of coarser gravel. The two causes are, however, quite distinct, and either may act alone or both in conjunction.

"The dredgings in the Eddystone neighbourhood are not perhaps so many or so scattered as might be desired for this discussion, the objective having been rather zoological than geological. None the less, it is interesting to note the relative positions of the fine textures and the coarse textures. With one exception the fine textures occur at some considerable distance from the reef, while the coarse textures are clustered around the reef or around the Hand Deeps. The exception as to a fine texture occurring near the reef is in the case of dredging $89 \mathrm{~B}$, taken from the centre of the channel between the Hand Deeps and the Eddystone reef. 
"Dredging 85 is remarkable for the manner in which the quartz grains have been rounded and polished, and also for the extremely coarse texture of the 'fine sand,' VII. As has been pointed out, this grade may either have a maximum coarseness, in which all the grains are of such size as to barely pass through the $0.5 \mathrm{~mm}$. mesh, or may approximate to silt. In the present instance the maximum coarseness is closely approximated. (The actual silt only forms 0.6 per cent. of the whole sample.) The greater portion of the sample is almost uniformly distributed between III., IV., V., and VI., a feature which does not recur. The average grade is 4.597 , or almost a mean between IV. and V. The conditions at this point, therefore, are unfavourable to the existence of either coarse gravel or fine sand; of the first, it is suggested, because the strong wave actions breaks up all large particles, of the second, because the same action will not allow small particles to settle. Add to this the rounded and polished quartz grains, grains rounded as they are practically never found on any beach, and almost every individual grain so polished, and the conclusion should apparently be that here is a centre of wave action. And yet it lies below the 30 -fathom line. But at the same time it lies under and to the westward of the Eddystone reef, which, rising above low-water, meets and breaks the south-west Channel seas.

"The sudden check to the great Channel rollers can certainly not be effected without the accompanying creation of intense currents in the neighbouring depths, and these it is that must be looked to as providing the necessary abrading forces. That these forces only operate at intervals may be gathered from the occurrence in this storm-washed sand of fair-sized specimens of Rotalia beccarii and Miliolina seminulum. The more delicate foraminifera are, however, conspicuously absent.

"The sand grains at 87 also show a similar but not equally finished polish. This point, however, lies further to the north of the highest point of the reef. To the north-west of the Eddystone the Hand Deeps also take a share in arresting and converting the surface-wave motion.

"Between the reef and the Hand Deeps the back-wash, reflux currents or arrested and converted wave motion have scooped and maintain a channel, represented by the incurve of the 30 -fathom line on the chart. All around the margin of this area there is evidence of wash, which must result in the formation of a considerable amount of fine detrital matter, and this not being able to settle when formed is constrained to collect in the quieter but still disturbed waters of the centre of the channel and forms the deposit at $89 \mathrm{~B}$, 56.8 per cent. of which is fine sand, a fine texture, but not comparable with, say, 92, which lies well clear of the reef and has 90.9 per cent. of fine sand, or with 102,91 , and 104 , with $85 \cdot 4$ per cent., $82 \cdot 7$ per cent., and $95 \cdot 8$ per cent. of fine sand respectively. It is, however, more nearly comparable with 90 , which lies at the northern extreme of the eastern Eddystone channel and has 688 per cent. of fine sand. Dredging $89 \mathrm{~B}$ also differs from all the other fine texture sands in having a large percentage $(29 \cdot 2$ per cent.) of medium sand.

"The conclusion which apparently follows these considerations is that the 
deposits around the Eddystone reef owe their coarse texture, in part at least, to the intense wave action which prevents the accumulation of the finer particles, in part to the same intenser action which provides additional coarse particles at the expense of the neighbouring submerged rock surfaces.

"The finer deposits elsewhere are in more quiescent localities, with no abrupt changes in the levels of the bottom to deflect the surface waves.

" 105 and 106 (Ground XVII.) are subject to totally different geological and other conditions, and more dredgings from their locality would be necessary to fully appreciate the circumstances affecting them.

"It is to be noted that no rock fragments occur which must have necessarily, or have even probably, been drifted from the neighbouring shores, guarding, however, the case of 105 and 106 , in which it is none the less quite possible and even probable that the Archean schists underlie the gravels in which they occur.

"Three of the samples of silt have been approximately analysed, with the result set out in the following table. The results should be accurate to the nearest 0.25 per cent.

\section{Analysis of Silts.}

Loss on Ignition.

$\begin{array}{lll}83 & 94 & 103\end{array}$

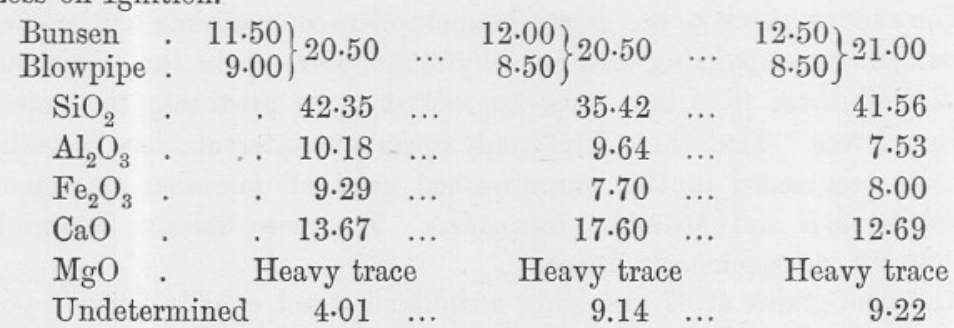

"It is apparent that the $\mathrm{CaO}$ obtained in these analyses is more than can be accounted for by the organic $\mathrm{CaCO}_{3}$, the figures being:

$$
\begin{aligned}
& \mathrm{CaO} \text { in present analysis, } \quad \mathrm{CaO} \text { equivalent to organic }
\end{aligned}
$$

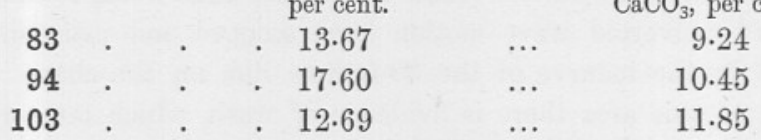

"On the other hand, the loss on ignition before blowpipe after previous ignition over bunsen appears to roughly represent the $\mathrm{CO}_{2}$ in the organic carbonate of lime. Thus:

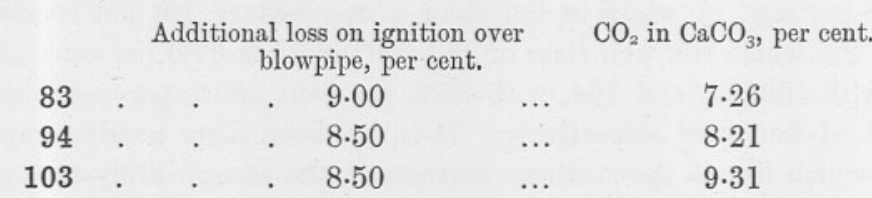

"The loss on ignition has accordingly been given in two figures, of which the figure for loss over bunsen fairly represents the more volatile substances and organic matter. 
"Under the head of 'undetermined' must be classed the alkalies, any slight traces of metallic oxides, and a small residue of $\mathrm{CO}_{2}$ left after ignition.

"All the samples were fairly thoroughly washed before analysis to remove salts derived from sea-water, and were desiccated before ignition."

\section{SeCtion V.}

\section{DESCRIPTION OF THE GROUNDS INVESTIGATED.}

The grounds from the Eddystone to Start Point lying in the neighbourhood of the 30 -fathom line fall naturally into four groups. The grounds around the Eddystone rocks, comprised within a circle of about four miles radius, having the lighthouse for its centre, are for the most part coarse grounds, with bottom-deposits of gravel or broken shell mixed with more or less mud or fine sand. Towards the outer limit of the circle the deposits become more and more sandy in nature. These grounds will be referred to in a general way as the Eddystone Grounds. (See Chart I.) South of Bolt Head the bottom-deposit is broken shell-gravel, and the ground here will be named the Bolt Head Shell-gravel Ground. (Chart I., Ground XVII.) Between the Eddystone Grounds and the Bolt Head Shell-gravel is a stretch of fine sand, the Eddystone Trawling Ground, the inner or northern portion of which will be distinguished as the Inner Eddystone Trawling Ground, the outer or southern portion as the Outer Eddystone Trawling Ground. (Chart I., Grounds I. and II.). Between Prawle Point and the Start is a patch of ground with many stones, the Prawle Stony Ground. (Chart I., Ground XVIII.)

The lists of species living on the various grounds will be arranged according to zoological groups, but in the description of the fauna of each ground, which precedes the list, the species will be grouped according to their general habit, the following kinds being distinguished:-

1. Burrowing species.

2. Fixed and clinging species.

3. Wandering or free species.

Associated species will in all cases be ranged with their hosts, the host being, in the case of fixed and burrowing animals, the one most intimately connected with the bottom-deposit, in the case of wandering species, the one having the greater powers of locomotion. It will be found that the burrowing and fixed species, with their associates, are the most restricted in distribution by the nature of the bottomdeposit, whilst the wandering species may exist upon bottoms of many 
different textures, when the deposit is once sufficiently firm to support their weight. The distribution of the wandering species will therefore depend, under the same conditions of temperature, water-movement, etc., chiefly upon the presence of a suitable food-supply and the absence of enemies.

In considering the geographical distribution of marine animals Forbes introduced the idea of a specific centre, by which he meant the locality, named also the metropolis of the species, where the species flourished in large numbers, and he showed that as one passed away from this locality the species became less and less abundant, until it finally disappeared. In what follows I think I have been able to show that the facts with regard to the local distribution of species are of a very similar kind. Many instances will be given of a species being specially abundant upon one particular patch of ground, where the nature of the bottom-deposit or some other physical condition is specially suited to its requirements, and in almost every case of this kind it will be found that the species is taken in smaller numbers on all the immediately surrounding grounds, even though the general nature of the fauna and of the bottom-deposit of the latter grounds may be very different. In this way the fauna of any particular ground depends not only on the nature of the ground itself, and the physical conditions to which it is subject, but also to a greater or less extent upon the predominant fauna on neighbouring grounds, which in its turn depends upon the physical conditions there existing.

In the descriptions of the grounds, places where a species is especially abundant will be referred to as centres of distribution of the species, and such centres will be spoken of as influencing the fauna of surrounding grounds.

The numbers of the different grounds have been arranged according to the texture and general character of the bottom-deposit. Grounds I. to VIII. are all fine sand grounds, of which I., II., and III. show the fine sand fauna in its most typical forms. Grounds IX. to XIII. are coarse gravels mixed with sand or mud, of which IX. is the most typical. Grounds XIV. and XV. are fine gravel, of which XIV. is typical. Grounds XVI. and XVII. are clean broken-shell gravel, and Ground XVIII. is stony. In order to understand the nature of the fauna on many of the intermediate grounds, it is necessary that acquaintance should be first made with that of the various typical grounds.

For a list of the individual hauls see Table I., p. 521. 


\section{Ground I. The Inner Eddystone Trawling Ground.}

Hauls. 50 (Dr.), , 51 (Dr.), 81 (B.-tr.), 82 (B.-tr.), 92 (O.-tr. and C.-dr.). The approximate limits of this ground are, on the north the 28 -fathom line, south the 33 -fathom line, west the Eddystone Grounds (comprised in a circle of four miles radius, with the lighthouse as centre), and east, a line drawn north and south about nine miles east of the Eddystone. (Chart I., Ground I.)

Bottom-deposit. Fine sand. The texture in haul 92 was found to be :-

$\begin{array}{rllllll}\text { IV. } & \text { Fine Gravel } & \ldots & \ldots & \ldots & 0.2 & \text { per cent. } \\ \text { V. } & \text { Coarse Sand } & \ldots & \ldots & \ldots & 0.8 & \\ \text { VI. } & \text { Medium Sand } & \ldots & \ldots & \ldots & 4.8 & \text { " } \\ \text { VII. } & \text { Fine Sand } & \ldots & \ldots & \ldots & 90.9 & " \\ \text { VIII. } & \text { Silt } \ldots & \ldots & \ldots & \ldots & 3.4 & ,\end{array}$

[92. Average grade of sample, 6.971. Percentage of carbonate of lime in whole sample, $17 \cdot 41$. Highest percentage occurs in IV., which contains 82.43 per cent, but this and V., containing 74.40 per cent., may be passed over as constituting but a small portion of the whole sample. VI. contains 58.00 per cent. A fine-textured deposit owing its low percentage of carbonate of lime to the fact that VII., which forms 90.9 per cent. of whole sample, only contains 14.63 per cent. of $\mathrm{CaCo}_{3}$.

Triassic material is largely present, some Devonian and no Eddystone reef.

Foraminifera are fairly plentiful. The following are the species present in VI. and VII., arranged in order of frequency:-Rotalia beccarii (greatly predominant), Miliolina seminulum, Truncatulina lobatula, Textularia gramen, Bulimina pupoides, Discorbina rosacea, Bolivina punctata, Miliolina bicornis (reticulate variety). In all eight species.-R. H. W.]

Unbroken shells were scarce, with the exception of Cardium echinatum shells.

Burrowing species. Astropecten irregularis, Cardium echinatum, $\dagger$ and Dentalium entale are the common burrowing forms on this ground. Corystes cassivelaunus was present in haul 92 only, where, however, it was plentiful. (Cf. p. 397.)

Fixed species. The fact that few shells are present causes fixed species to be scarce. Cellaria fistulosa and sinuosa are moderately

* Dr. $=$ Dredge. B. -tr. $=$ Beam-trawl. O.-tr. $=$ Otter-trawl. C.-dr. $=$ Dredge fitted with canvas bag.

+ The presence of Cardium echinatum on this ground and in the fine sand of the outer trawling-ground is inferred from the fact that fresh valves, often still joined together, are a constant feature of the hauls, and are the only shells at all plentiful. The species is known ( $c f$ p. 500) to be a sand-dwelling one. 
abundant, fixed in the sand by their root-fibres; Antennularia antennina and ramosa are fairly common, fixed in the sand by "sponge-like masses of interlacing fibres" (Hincks); whilst Aglaophenia myriophyllum, fixed in a similar way, also occurs, though not frequently.

The tubes of the polychæte Thelepus (cincinnatus?) serve as an attachment for the hydroid Sertularella Gayi, which is the commonest and most typical hydroid on the ground, whilst to the base of the hydroid Ascidiella scabra and Sabella pavonina are attached. Sertularella polyzonias, Eudendrium ramosum, Bougainvillia ramosa, Obelia dichotoma, and Clytia Johnstoni also occur attached to other hydroids, or to polychaete tubes. Halecium halecinum and H. Beanii are represented by one or two colonies only in a haul, or are entirely absent, and $H$. halecinum, at any rate, must be regarded as an immigrant from coarser ground.

Stray tubes of Chaetopterus variopedatus were taken in hauls 82 and 92 only, and are also clearly immigrants from neighbouring grounds.

Of the other fixed species Alcyonium digitatum only occurs in moderate quantity, and the colonies, generally attached to Cardium echinatum shells, are small. Epizoanthus incrustatus, which forms a feature of the outer trawling-ground (Ground II.), has never been taken on the inner. The polyzoa Bicellaria ciliata, Scrupocellaria scruposa, and Cellepora avicularis are found attached to hydroids, but, owing to the absence of shells, there are few incrusting polyzoa.

Wandering species. Owing in all probability to the scarcity of fixed and burrowing forms to serve as a food-supply, the number of wandering species is also small.

Pecten opercularis is scarce, and Asterias mbens and A. glacialis, which generally are found feeding on the Pecten on neighbouring grounds, are never present in numbers. There are usually a few Ophiura ciliaris, but Ophiothrix fragilis is only represented by small specimens at the roots of Cellaria or hydroids. Palmipes placenta was taken in one haul only (82).

Eupagurus Bernhardus (with Sagartia parasitica or Hydractinia echinata on the Buccinum undatum shells which they inhabit), Galathea disper'sa and Porcellana longicornis are the only Decapod Crustacea which can be considered common on this ground. There are a few examples only of Stenorhynchus longirostris and Inachus dorsettensis, which live amongst the hydroids, whilst Maia squinado and Eurynome aspera were taken twice.

The fish fauna is characterised by the abundance of Arnoglossus laterna, Zeus faber, Trigla pini, Trigla gurnardus, Callionymus lyra, and Golius Jeffreysi.

From the list of species it will be seen that haul 82 contains several 
stray specimens of species which are typical of coarser grounds than the present. This suggests the presence of such grounds near it, and it is not unlikely that they will be found on the unexplored area between the present ground and the Bolt Head Shell-gravel, Ground XVII. (See Chart I.)

\section{List of Species. Ground I.}

Foraminifera.

Truncatulina lobatula. On Sertularella Gayi and Cellaria. Plentiful.

Porifera.

Cliona celata. Boring Buccinum undatum shell in 92 .

\section{HydrozoA.}

Hydractinia echinata. On shells inhabited by Eupagurus Bernhardus.

Eudendrium ramosum.

Heterocordyle Conybeari. On Buccinum undatum shells.

Bougainvillia ramosa. Occasional large colonies.

Clytia Johnstoni. On other hydroids.

Obelia dichotoma. Fairly common, growing on polychaete tubes and other hydroids.

Campanularia Hincksii.

, verticillata. Not frequent.

Lafoea dumosa, var. robusta. Not frequent.

Lafoea fruticosa. In 81 only.

Cuspidella costata. On hydroids.

Coppinia arcta. On Lafoea dumosa, var. robusta.

Halecium halecinum. Scarce. Small colonies only.

Halecium Beanii. Somewhat more frequent than $H$. halecinum.

Sertularella Gayi. Not in large quantities, but one of the most abundant hydroids on the ground.

Sertularella polyzonias. Not in large quantity.

Diphasia rosacea. In 82 only.

Sertularia argentea. In 81 only.

Hydrallmania falcata. Not frequent.

Antennularia antennina. Plentiful.

" ramosa. Less frequent than A. antennina.

phe myriophyllum. One or two pieces in 82 and 92 only.

Plumularia Catharina. Ordinary form and green variety in 82 only.
ACtinozoA.

Alcyonium digitatum. Not plentiful. Generally on Cardium echinatum shells

Sagartia parasitica. On shell of Buccinum undatum inhabited by Eupagurus Bernhardus. Not common.

\section{Echinodermata.}

Astropecten irregularis. In every haul.

Solaster papposus. One in 92 only.

Palmipes placenta. In 82 only.

Asterias glacialis. $\}$ Few only.

Ophiura ciliaris. Few only.

Ophiothrix fragilis. One or two small ones only, at base of hydroids and Cellaria.

\section{Nemertina.}

Carinella annulata.

Tetrastemma flavidum. ,, dorsale.

Lineus bilineatus.

\section{Polychaeta.}

Lagisca propinqua. , rarispina.

Evarne impar.

Hermadion assimile. One in 92 only recorded.

Acholoe astericola. Commensal with Astropecten irregularis.

Nereis pelagica. Recorded in 50 only.

Chaetopterus variopedatus. One tube in 82 and one in 92 only.

Nicolea venustula. One small one in 92 . Thelepus. Moderately plentiful.

Sabella (pavonina?). Generally at base of Sertularella Gayi.

Dasychone bombyx. Several in 92 .

Hydroides pectinata. Generally on Buccinum undatum shells, inhabited by Eupaguris Bernhardus.

\section{Crustacea.}

Homarus vulgaris. Two specimens in 81 only. 
Eupagurus Bernhardus. In Buccinum undatum shells, generally with Hydractinia echinata or Heterocordyle Conybeari, less frequently with Sagartia parasitica. Shells sometimes covered with Serpulids.

Porcellana longicornis.

Galathea dispersa.

Stenorhynchus longirostris. A few only. Inachus dorsettensis. A few in 92 only.

Maia squinado. One or two specimens in 82 .

Hyas coarctatus. In 50 only.

Eurynome aspera. A few only taken.

Corystes cassivelaunus. Many specimens in 92 ; none in the other hauls.

Atelecyclus heterodon. One or two specimens in 82 only.

Scalpellum vulgare. At base of stalk of hydroids.

Mollusca. Living.

Saxicava rugosa, var. arctica. Small free form attached to shells and hydroids. Scarce. In 92 only.

Pecten opercularis. Small number only of adult. Many small ones on hydroids.

Chiton asellus. In 92 only on Lepratia foliacea.

Dentalium entalis. Buried in sand.

Tritonia plebeia.

Dendronotus arborescens.

Doto fragilis.

,, pinnatifida.

$\int^{\prime}$ On hydroids.

Cratena viridis.

Coryphella Landsburgii.

Lamellidoris oblonga. On Cellaria.

Loligo, sp. One or two small ones.

\section{Shells.}

Cardium echinatum. Recent shells numerous, sometimes covered with Serpulids, or bearing colonies of Alcyonium or hydroids (Sertularella and Halecium). Generally free from incrusting Polyzoa. On one shell Membranipora Dumerilii was growing on the outer side and Hippothoa divaricata on the inner.
Buccinum undatum. Inhabited by Eupagurus Bernhardus.

PolyzoA.

Cellaria sinuosa. ) In considerable fistulosa. quantity.

Scrupocellaria scruposa. Small quantity only.

Bicellaria ciliata. Small quantity only.

Cellepora avicularis. On hydroids.

Membranipora Dumerilii. On outer side of a Cardium echinatum shell in 51.

Hippothoa divaricata. On inner side of Cardium echinatum shell in 51.

Lepralia foliacea. One piece (dead?) in 92 only, on which were fixed Serpulids, Ascidiella scabra, Chiton asellus, and encrusting polyzoa. Schizoporella linearis.

Porella concinna.

Mucronella ventricosa.

In 92 only grow-

Diastopora patina.

Lichenopora hispida.

Pedicellina cernua.

\section{Tunicata.}

Polycarpa varians. Small specimens on a Buccinum shell in 92 only.

Ascidiella scabra, Attached to base of hydroids.

\section{Fishes.}

Arnoglossus laterna (Scaldback). Plentiful.

Gadus minutus. Three specimens in haul 92 only.

Merluccius vulgaris (Hake). One in 92 only.

Capros aper (Cuckoo).

Zeus faber (John Dory). Six specimens in haul 81 .

Trigla pini (Red gurnard). A few in each haul.

Triglagurnardus(Greygurnard). Plentiful. ,, hirundo (Tub gurnard). One in 81 only.

Callionymus lyra (Dragonet). A few specimens.

Gobius Jeffreysi (Jeffreys' Goby). Numerousamongst Cellaria, \&c.

Scyllium canicula (Rough dog). One small one in 81.

Raia clavata (Thornback). One in 81 . 


\section{Ground II. The Outer Eddystone Trawling Ground.}

Hauls. 22 (O.-tr.), 23 (O.-tr.), 24 (O.-tr.), 25 (Dr.), and 104 (B.-tr. and C.-dr.). The outer trawling ground extends southward from the 33 -fathom line (10 miles south of the Plymouth Mewstone), and hauls have been made to about the 35 -fathom line. The fine sand, however, which forms its bottom-deposit extends for a long distance into the Channel. The area examined during the present investigation lies between the Eddystone Grounds on the west and a line similar to that bounding the inner trawling ground on the east.

Bottom-deposit. As will be seen from Table II., this is the finest sand ground examined. The composition in haul 104 was found to be:-

$\begin{array}{rllllll}\text { IV. } & \text { Fine Gravel } & \ldots & \ldots & \ldots & 0 \cdot 1 & \text { per cent. } \\ \text { V. } & \text { Coarse Sand } & \ldots & \ldots & \ldots & 0 \cdot 2 & , \\ \text { VI. } & \text { Medium Sand } & \ldots & \ldots & \ldots & 2 \cdot 1 & , \\ \text { VII. } & \text { Fine Sand } & \ldots & \ldots & \ldots & 95 \cdot 8 & , \\ \text { VIII. } & \text { Silt } \ldots & \ldots & \ldots & \ldots & 1.9 & ,\end{array}$

[104. Average grade of sample, 6.998. Percentage of carbonate of lime in whole sample, $15 \cdot 80$. The following are the species of Foraminifera present in Grades VI. and VII., arranged in order of frequency :Rotalia beccarii, Miliolina seminulum, Truncatulina lobatula, Planorbulina mediterranensis, Discorbina rosacea, Textularia gramen, Miliolina trigonula. R. H. W.].

Unbroken shells were scarce, with the exception of Cardium echinatum shells. The ground is very barren, and all the five hauls made on it yielded comparatively few specimens. The fauna is, however, well characterised, and has many invariable and distinguishing features, which mark it out from all the other grounds.

Burrowing species. Astropecten irregularis, Cardium echinatum, * and Nucula nitida are the commonest species. Corystes cassivelaunus, a characteristic fine sand species, was only represented by one specimen in haul 22. Echinocardium cordatum and Echinocyamus pusillus were present in 104. The absence of Dentalium from the sand in the sample taken at haul 104 is noteworthy.

Fixed species. As on Ground I., these are scarce owing to the scarcity of shells. The absence of species which fix themselves in the sand by a mass of root-fibres is noteworthy, this kind being represented by one colony of Antennularia antennina in haul 25, and by an occasional piece of Cellaria, both species of the latter genus being, however, very

* The evidence for the presence of this species is similar to that for its presence on Ground I., viz., the constant capture of recent shells of the species and of shells of no other kind. 
scarce. I imagine that the scarcity of species of this habit is due to the fineness of the sand, and there are two ways in which this might be detrimental. Either the general nature of the sand might be too loose to afford a satisfactory hold, or the absence of larger particles mixed with the fine sand might prevent the embryos from fixing in their earliest stage. A comparison of the composition of the sand on this ground with that on Ground I. shows that they differ in two ways. There is a smaller percentage of medium and coarse sand on Ground II., but at the same time there is a somewhat smaller proportion of silt. The first of these differences might make it more difficult for the embryos to fix, whilst the second might tend to make the sand particles bind together somewhat less firmly.

Of the other fixed species Sertularella Gayi is not uncommon, fixed generally, as on the inner trawling ground, to the tube of the polychæte Thelepus (cincinnatus?), and the abundance of Sertularia abietina, which is not present on the inner ground nor on the Eddystone Grounds, is a characteristic feature. I have not satisfied myself as to the mode of attachment of this species on the present ground, the specimens examined for this purpose not having afforded evidence on the point. On the Sertularia the creeping variety of Lafoea dumosa and the hydroid Coppinia arcta are plentiful, as well as a species of Foraminifera (Truncatulina lobatula) tubes of Spirorbis and the Polyzoa Cellepora avicularis, Cellepora ramulosa, and Idmonea serpens. Plumularia Catharina is fairly plentiful on the ground, and as will be seen from the list several other hydroids are occasionally taken.

Three other fixed species are characteristic of Ground II., viz., Alcyonium digitatum, large colonies of which are abundant, fixed often to Cardium echinatum shells; Chondractinia digitata, fixed to the same kind of shells; and Epizoanthus incrustatus in its free form (see Haddon, No. 35, p. 638), which is constantly taken.

Ascidiella scabra attached to Sertularella Gayi was not plentiful, whilst a few Ciona intestinalis fixed to shells are recorded. The few shells which are present are generally free from encrusting Polyzoa.

Wandering species. Ophiura ciliaris is present in moderate numbers, but only a few small specimens of Ophiothrix fragilis, clinging to the roots of hydroids, were seen. Asterias rubens and $A$. glacialis were often represented by large specimens. Of Crustaceans Galathea dispersa, Eupagurus Bernhardus, and Anapagurus lcevis were constantly taken, together with occasional specimens of Stenorhynchus longirostris, Inachus dorsettensis, and Eurynome aspera. A few fair-sized Pecten opercularis were obtained in two of the hauls. Fishes were very scarce, the three species represented being Trigla pini, Trigla gurnardus, and Raia clavata, of which only a few specimens were taken. 


\section{List of Species. Ground II.}

\section{Foraminifera.}

Truncatulina lobatula. Abundant on Sertularia abietina.

\section{Ponifera.}

Suberites domuncula. Large pieces on Dentalium shell.

\section{HyprozoA,}

Hydractinia echinata. On shells inhabited by Eupagurus Bernhar. dus. Not plentiful.

Eudendrium ramosum. One colony 4 to 5 inches high in haul 22 .

A fragment of the small variety in 104

Perigonimus repens. Fine colony in 104.

Bougainvillia ramosa. A large colony in 104 only.

Clytia Johnstoni. Common on other hydroids.

Lafoea dumosa. Creeping variety only, on Sertularia abietina.

Coppinia areta. Common on Sertularia abietina.

Sertularella Gayi. Not uncommon.

Sertularella polyzonias.

Sertularia abietina. In considerable quantity. Very characteristic of this ground. Covered with Spirorbis and Truncatulina.

Diphasia attenuata. Small quantity only. Hydrallmania falcata One or two pieces in a haul.

Antennularia antennina. A colony in 25 only.

Plumularia pinnata. Two large, luxuriant colonies with gonophores in 24 only.

Plumularia Catharina. Large colonies moderately plentiful.

\section{ActrnozoA.}

Sagartia parasitica, on shell of Buccinum undatum, inhabited by Eupagurus Bernhardus. Not common.

Chrondractinia digitata. Generally on shells of Cardium echinatum. A few specimens only.

Epizoanthus incrustatus. Moderately common. Not frequent on any of the other grounds described in this report.
Alcyonium digitatum. Large pieces plentiful, often on Cardium echinatum shells, sometimes on shells of Buccinum undatum inhabited by Eupagurus Bernhardus.

\section{ECHINODERMATA.}

Asterias rubens. ¡Both species present. , glacialis. $\int$ Large specimens.

Luidia Sarsi. One large specimen in 24. Astropecten irregularis. Common.

Ophiura ciliaris. Fairly common in 22 and 23 , few or none in other hauls.

Ophiothrix fragilis. One or two small specimens only in each haul.

Echinus acutus. Small specimens only in 23 .

Echinus miliaris. A few small.

Echinocardium cordatum. Two specimens in 104 .

Echinocyamus pusillus. In stomach of Astropecten irregularis.

\section{Nemertina.}

Tetrastemma dorsale.

\section{Polychaeta.}

Lepidonotus squamatus. One in 104 only. Lagisca propinqua.

Laenilla setosissima, One in 104 only.

Acholoe astericola. In ambulacral groove of Astropecten irregularis.

Nereis procera. Several in 104 and 24 .

Chaetopterus variopedatus. One tube in 24 .

Thelepus.

Sabella (pavonina ?). Few only.

Dasychone bombyx.

Hydroides pectinata. On Cardium echinatum and Buccinum undatum shells.

Potamoceros triqueter. Few only.

Spirorbis sp. Abundant on Sertularia abietina.

Crustacea.

Eupagurus Bernhardus. Common in shell of Buccinum undatum.

Anapagurus laevis. Common in Natica shells.

Galathea dispersa. Numerous amongst the hydroids. 
Porcellana longicornis.

Stenorhynchus longirostris. Not frequent. Inachus dorsettensis, Not frequent.

Eurynome aspera. One or two in 22 only. Corystes cassivelaunus. One female specimen in 22.

Ebalia tumefacta. Few in 23 only.

Scalpellum vulgare. Common at base of hydroids.

\section{Mollusca. Living.}

Nucula nitida. Many specimens buried in the sand.

Pecten opercularis. A few adult specimens only, but very many small ones attached to hydroids,

Anomia patelliformis. Attached to Pecten. Ovula patula. On Alcyonium digitatum. Tritonia Hombergii. Small in 23 only.

Galvina tricolor. In 104.

Doto coronata. In 104. Spawning on hydroids.

Hero formosa. In 22.

Loligo sp.

$$
\text { Shells. }
$$

Cyprina islandica. Recent shells.

Cardium echinatum. Recent shells numerous. Typical of this ground.
Nucula nitida.

Pecten opereularis. Few only.

Dentalium entalis.

Aporrhais pes-pelecani. One in 23 only.

Natica nitida. Inhabited by Anapagurus laevis.

Buccinum undatum. Inhabited by Eupagurus Bernhardus.

\section{PoLYzoA.}

Cellaria sinuosa. $\}$ A small quantity only. Cellepora avicularis.

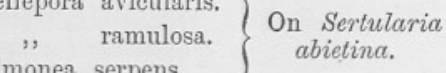

Idmonea serpens.

Membranipora Flemingii on living Pecten opercularis.

\section{Tunicata.}

Ascidiella scabra. A few small specimens attached to hydroids.

Ciona intestinalis. A few only.

A compound Ascidian.

\section{Pisces.}

Trigla pini (Red Gurnard). Few only.

„, gurnardus (Grey Gurnard). Few only.

Raia clavata (Thornback). Two specimens in haul 104.

\section{Ground III. The Outer East Eddystone Sand.}

The position of this ground will be seen on the charts.

Hauls. 57 (B.-tr.), 72 (B.-tr.), 91 (O.-tr. and C.-dr.), 49 (O.-tr.), 53 (Dr.), and 56 (B.-tr.).

Bottom-deposit. Fine sand, which is somewhat coarser than that of Ground I., and less muddy than Ground V., the two adjoining fine sand grounds.

The texture of the sample at haul 91 was :-

$\begin{array}{rllllll}\text { IV. } & \text { Fine Gravel } & \ldots & \ldots & \ldots & 0.5 & \text { per cent. } \\ \text { V. } & \text { Coarse Sand } & \ldots & \ldots & \ldots & 2.5 & \\ \text { VI. } & \text { Medium Sand } & \ldots & \ldots & \ldots & 13 \cdot 2 & \\ \text { VII. } & \text { Fine Sand } & \ldots & \ldots & \ldots & 82 \cdot 7 & \\ \text { VIII. } & \text { Silt } \ldots & \ldots & \ldots & \ldots & 1.1 & \end{array}$

[91. Average grade of sample, 6.814. Percentage of carbonate of lime in whole sample, 14:13. Highest percentage occurs in IV., which contains $64 \cdot 70$ per cent., but this forms so small a portion of the whole sample that V. at 28.8 per cent. should be taken. As in 90 this is a fine-textured deposit with low percentage of carbonate of lime. The rock materials are Triassic and Eddystone reef. In 91 VI. Foraminifera 
are comparatively scarce, only twenty individuals were found in 0.45 grams (seven grains), or 44 per gram. In 91 VII. sixty-seven foraminifera were counted in 0.13 gram (two grains), or 515 per gram. In VI. Rotalia beccarii was present to the almost total exclusion of every other form, while in VII. the individuals of this species practically equalled in number those of all other species added together. Arranged in order of frequency the following is the list of species:-Rotalia beccarii, Miliolina seminulum, Textularia gramen, Truncatulina lobatula, Discorbina rosacea, Bolivina dilatata, Planorbulina mediterranensis. In all, seven species.-R. H. W.]

There are very few shells on this ground.

Burrowing species. As on the inner trawling ground (I.), Astropecten irregularis and Dentalium entalis are abundant. Corystes cassivelaunus, which on the inner trawling ground was taken in haul 92 only, is here abundant in all hauls excepting 53 and 56 . From the position of the various hauls it will therefore be seen that a centre of distribution of this species occurs on the S.E. portion of Ground III. and the N.W. of Ground I. (Chart XIII., $c f$. also p. 492.) There is no evidence of Cardium echinatum on the present ground. Aphrodite aculeata is occasionally taken.

Fixed species. The most obvious distinction between the ground now under consideration and the inner trawling ground (I.), which adjoins it, is the much greater abundance of Cellaria and the much richer hydroid fauna. Of the hydroids which fix themselves in the sand by a felt-work of root-fibres Aglaophenia myriophyllum is invariably taken, and is much commoner than on Ground I., and Antennularia antennina is common also.

Sertularella Gayi is very common, being by far the most plentiful hydroid on the ground, and is generally attached to the tube of Thelepus. It is associated, as on the inner trawling ground, with Sabella (pavonina?) and Ascidiella scabra. The other characteristic hydroids are Sertularella polyzonias, Eudendrium ramosum, Bongainvillia ramosa, Plumularia pinnata, Plumularia Catharina, and occasional specimens of Hydrallmania falcata. Lafoea dumosa, var. robusta, is not uncommon, associated with Coppinia arcta and Dondersia banyulensis. Occasional specimens of Halecium halecinum and Halecium Beanii are the result of the influence of the neighbouring Eddystone gravel grounds, which is also shown by one or two specimens of Chaetopterus. Alcyonium digitatum occurs only as small colonies, and one specimen of Paraphellia expansa was taken in haul 72. Cellaria fistulosa and Cellaria sinuosa are both abundant, and Bicellaria ciliata, Cellepora avicularis, Cellepora ramulosa, Scrupocellaria scruposa are common on hydroids, but incrusting Polyzoa are very scarce.

NEW SERIES. - VOL. v. NO. 4 . 
Wandering species. Asterias rubens and A.glacialis are not numerous, and Pecten opercularis, which is their usual food on these grounds, is also scarce. Ophiura ciliaris occurs in small numbers, and Ophiothrix fragilis is again only represented by small specimens at the roots of hydroids and Cellaria. Palmipes placenta was taken twice (hauls 53 and 57), and one or two specimens of Solaster papposus and Henricia sanguinolenta were seen. Echinus miliaris was the only species of Echinus.

Buccinum undatum was common. Stenorhynchus longirostris and Inachus dorsettensis were abundant amongst the hydroids, and Pandalus brevirostris amongst the Cellaria. Galathea dispersa, Porcellana longicornis, Eurynome aspera, Portunus depurator were also common, together with Eupugurus Bernhardus, associated with Sagartia parasitica or Hydractinia echinata, and Eupagurus Prideauxii, associated as usual with Adamsia palliata.

Fishes were more numerous here than on any other ground upon which the trawl was used. The species most plentiful were Pleuronectes limanda and microcephalus, Trigla pini and gurnardus, Callionymus lyra and Gobius Jeffreysi.

\section{List of Species. Ground III.}

\section{Foraminifera.}

Truncatulina lobatula. Abundant, attached to hydroids, especially to Sertularella Gayi.

Porifrra.

Suberites domuncula. One with Anapagurus laevis in 56 only.

HYDROzOA.

Hydractinia echinata. In 72 only, on shell inhabited by Eupagurus Bernhardus.

Eudendrium ramosum. Plentiful.

, $\quad$ sp. A small species of Eudendrium (not $E$. capillare).

Bougainvillia ramosa. Large colonies.

Clytia Johnstoni. Abundant on hydroids and Cellaria.

Obelia dichotoma. Scarce. On Cellaria.

Campanularia Hincksii. On hydroids. verticillata. In 72 only.

Lafoea dumosa, var. robusta. In quantity, attached to shells.

,, fruticosa Not frequent.

Coppinia areta. Common, on Lafoea dumosa.

Halecium halecinum. Small quantity only.
Halecium Beanii. Less common than H. halecinum.

Sertularella Gayi. In large quantities, generally attached to Thelepus tubes. polyzonias. Less common than $S$. Gayi.

Sertularia argentea. Not frequent.

Hydrallmania falcata. A small quantity only.

Antennularia antennina. Plentiful.

,, ramosa. Not so common as A. antennina.

Aglaophenia myriophyllum. Plentiful. Several pieces in each haul of the trawl. Rooted in the sand.

Plumularia pinnata.

, Catharina. Plentiful.

ActinozoA.

Sagartia parasitica. On Buccinum undatum shell inhabited by Eupagurus Bernhardus. Not frequent.

Adamsia palliata. On shells inhabited by Eupagurus Prideauxii. Not frequent.

Alcyonium digitatum. Generally only small colonies on Pecten opercularis. 


\section{Echinodermata.}

Cucumaria lactea. Not abundant.

Astropecten irregularis. Numerous,

Palmipes placenta. One or two specimens in 53 and 57 only.

Solaster papposus. One or two in 72 only.

Henricia sanguinolenta. One or two in 72 only.

Asterias glacialis. A Always present, but ,, rubens. $\}$ not in large numbers.

Ophiura ciliaris. Several in 91 . Few or none in the other hauls.

Ophiothrix fragilis. A few small ones, generally at the roots of Cellaria.

Echinus miliaris. A few.

\section{Nemertina.}

None recorded.

\section{Polychaeta.}

Aphrodite aculeata. Three in 91 and one in 72 only.

Lepidonotus squamatus. One in 91 only. Lagisca propinqua. Not numerous.

Harmothoe imbricata. One in 91 only.

Hyalinoecia tubicola. One in 72 only.

Nereis fucata. In 57 and 91.

, procera. Several in 91.

Nephthys Hombergii. One in 91.

Chatopterus variopedatus. One or two

Nicolea venustula, in a haul only.

Thelepus. Many specimens.

Sabella (pavonina?). At base of Sertularella Gayi.

Dasychone bombyx. Numerous.

Serpula vermicularis.

Hydroides pectinata.

\section{Crustacea.}

Pandalus brevirostris. Many, living amongst the Cellaria and hydroids.

Eupagurus Bernhardus. Numerous in Buccinum undatum shells.

, Prideauxii. Not so frequent as E. Bernhardus. Shells covered with Adamsia palliata.

Anapagurus laevis. In 56 only, living in Suberites domuncula.

Porcellana longicornis. Abundant.

Galathea dispersa. Abundant.

Stenorhynchus longirostris. Abundant amongst hydroids and Cellaria.

Inachus dorsettensis. Abundant amongst hydroids and Cellaria.
Maia squinado. One in 56 only.

Eurynome aspera. A few only.

Cancer pagurus, In 56 only.

Portunus depurator. Absent in 72 and 91. Numbers taken in the remaining hauls.

Corystes cassivelaunus. Numerous in 49, 91, 72, and 57. Absent in 53 and 56 .

Scalpellum vulgare. Abundant at base of stalk of hydroids, especially of Antennularia antennina.

Mollusca. Living.

Pecten opercularis. Many in 49; comparatively few large ones in remaining hauls. Young specimens attached to hydroids numerous.

Anomia ephippium. On Pecten opercularis and on Buccinum undatum shells inhabited by Eupagurus Bernhardus.

Dentalium entalis. Numerous in the sand.

Buccinum undatum. Common.

Cypraea europaea. One or two in a haul,

Proneomenia aglaopheniae. Occasional specimens coiled on the stem of Aglaophenia myriophyllum.

Dondersia banyulensis. Occasional specimens on Lafoea dumosa, var, robusta.

Doto coronata. $\left.\begin{array}{l}\text { Doto coronata. } \\ \text { Archidoris tuberculata. }\end{array}\right\}$

Lamellidoris oblonga. On Cellaria.

$$
\text { Shells. }
$$

Buccinum undatum. Inhabited by Eupagurns Bernhardus.

Dentalium entalis.

[No Pecten or other common shells.]

$$
\text { Polyzoa. }
$$

$\left.\begin{array}{c}\text { Cellaria sinuosa. } \\ \text { fistulosa. }\end{array}\right\}$ In large quantity.

Scrupocellaria scruposa. Plentiful.

Bugula flabellata. Not generally plentiful.

Bugula avicularia. In 56 only.

Cellepora avicularis. Plentiful on

, ramulosa. $\}$ hydroids.

Idmonea serpens. Plentiful on hydroids. Alcyonidium gelatinosum. A little only. 
Cylindroecium dilatatum.
Pedicellina cernua. On hydroids.

Membranipora Dumerilii. On Buccinum shell in 53 only.

Microporella ciliata. , On Buccinum Mucronella ventricosa. $\quad$ shell in 53 Schizoporella auriculata. only.

Tunicata.

Ascidiella scabra. Numerous at base of Cellaria and hydroids, especially of Sertularella Gayi.

Botryllus, $s p$. Common on hydroids and Cellaria.

A compound Ascidian common on Cellaria. Fishes.

Pleuronectes platessa (Plaice). Not numerous,

Pleuronectes limanda $(D a b)$. Plentiful.

,, microcephalus (Lemon Dab). Plentiful.
Solea lutea. One in 56 only.

Arnoglossus laterna (Scaldback). Several specimens.

Capros aper (Cuckoo). Generally one or two specimens.

Zeus faber (John Dory). One or two in each haul.

Trigla pini (Red Gurnard). Plentiful.

, gurnardus (Grey Gurnard). Plentiful.

,, lineata (Parrot Gurnard). Two in 72 only.

Lophius piscatorius (Angler). One or two only.

Callionymus lyra (Dragonet). Plentiful.

Gobius Jeffreysi (Jeffreys' Goby). Plentiful amongst Cellaria, \&c.

Crystallogobius Nilssoni. Recorded in 91 only.

Scyllium canicula (Rough Dog). One small one in 91 only.

Raia, sp. A few small specimens.

\section{Ground IV. The Inner East Eddystone Sand.}

Two to three miles east of the Eddystone.

Hauls. 34 (O.-tr.), 39 (O.-tr.), 40 (Fine mosquito net), 77 (B.-tr).

The four hauls taken between two and three miles east of the Eddystone show a fauna in most respects similar to that of the fine sand of Ground III. (the Outer East Sand), but there are several important additional features, which indicate a coarser ground. No sample of the bottom-deposit was taken here. It is not unlikely that the hauls were made on two kinds of ground, first on fine sand similar to that of Ground III, and as the Eddystone was approached on a coarser deposit.

Shells are numerous, the common ones being Pecten opercularis, $P$. maximus, Tapes virginea, and Cardium echinatum.

Burrowing species. There are important differences in the burrowing species on this ground and on Ground III. Astropecten irreyularis is much less abundant here, and Corystes cassivelaunus is entirely absent. Atelecyclus heterodon was taken in haul 34, and Cardium norvegicum in both 34 and 39 . These differences all indicate an approach to the coarser Eddystone grounds.

Fixed species. The hydroid fauna is practically identical with that of the preceding ground, excepting that Halecium halecinum and H. Beanii are much more abundant, and Chaetopterus, to the tubes of which these species are often fixed, is also somewhat more plentiful. Cellaria is still plentiful.

The Ascidians and branched Polyzoa are identical with those of 
Ground III.; but incrusting Polyzoa, which were scarce on the latter ground, now become abundant with the increase in the number of shells.

Wandering species. All the important species on Ground III. are present, but in addition Ground IV. has the following:-Porania pulvillus (one in haul 39), Ophiura albida (one in 77), Ophiactis Balli (seen in 40 only), Echinus acutus and esculentus, Hyas coarctatus (in 39 only), Portunus pusillus* (in 39 only), Turritella communis (in 39 only), Pecten maximus, many Pecten opercularis, and with them an increase in the number of Asterias glacialis and A. mbens. The greater abundance of shells has already been noticed. All these features indicate an approach to the coarser Eddystone grounds.

The fish fauna is much less numerous than on Ground III., but the species present are all taken on that ground also.

\section{List of Species. Ground IV.}

Foraminifera.

Truncatulina lobatula. On hydroids, ete.

\section{Porifera.}

Cliona celata. Boring shells, especially Pecten and Lutraria.

HyDROZOA.

Hydractinia echinata, On shell inhabited by Eupagurus Bern-

Eudendrium ramosum. hardus. In 34 only.

, capillare. In 77.

, sp. Small species, not capil. lare.

Clytia Johnstoni. Plentiful.

Campanularia Hincksii. On Halecium and other hydroids.

Lafoea dumosa, var. robusta. Abundant. , fruticosa. In 77 only.

Halecium halecinum. Fairly abundant, growing on shells and on Chaetopterus tubes.

Halecium Beanii. Less abundant than H. halecinum.

Sertularella Gayi. Abundant, generally on polychaete tubes.

Sertularella polyzonias. Less frequent than S. Gayi. Generally on shells.

Sertularia argentea. Scarce. In 40 only. Hydrallmania falcata. A few colonies in each haul.
Antennularia antennina. Not very abun dant.

Aglaophenia myriophyllum. Abundant, fixed in the sand.

Plumularia pinnata. In 34 only.

,, setacea. In 34 and 77.

, Catharina. In 34 only.

\section{ActinozoA.}

Sagartia parasitica. On shells of Buccinum undatum, inhabited by Eupagurus Bernhardus. Not frequent.

Adamsia palliata. On shells inhabited by Eupagurus Prideauxii. Not frequent.

Alcyonium digitatum. Small colonies only, often on living Pecten opercularis.

Sarcodictyon catenata. Red variety. In 39 only.

Echinodermata.

Astropecten irregularis. Very few specimens.

Porania pulvillus. One specimen in 39 only.

Solaster papposus. Common in 77 , not frequent in other hauls.

Henricia sanguinolenta, One or two specimens in each haul.

Asterias glacialis. ) Common generally, , rubens. $\}$ only small ones in 77 .

* Portunus depurator and P. pusillus have been included under the head of wandering species on account of their marked adaptation for swimming. At the same time both species do sometimes burrow, although to what extent has never been determined. 
Ophiura ciliaris. Very few (none in 77). , albida. One small specimen in 77 .

Ophiothrix fragilis. A few small specimens at roots of Cellaria only.

Ophiactis Balli. Seen in 40 only.

Echinus acutus. Two specimens in 34 only.

, miliaris. Few only.

, esculentus. Several in 34 , not numerous in other hauls.

\section{Nemertina.}

Carinella annulata.

Amphiporus pulcher.

Lineus bilineatus.

Micrura fasciolata.

\section{Polychaeta.}

Aphrodite aculeata. One in 77 only.

Lagisca propinqua. In 39 only.

Hyalinoecia tubicola. Several in each haul.

Nereis pelagica. One in 34 only.

Chatopterus variopedatus. One or two specimens in 40 and in 77 .

Thelepus. Abundant.

Sabella. At base of Sertularella Gayi.

Dasychone bombyx. Not numerous.

Serpula vermicularis. Few only recorded in 77 .

Crustacea.

Pandalus brevirostris. Numerous amongst the Cellaria and hydroids.

Eupagurus Bernhardus. In Buccinum undatum shells. Not numerous.

Eupagurus Prideauxii. With Adamsia palliata. Not numerous.

Anapagurus laevis. In 39 only.

Poreellana longicornis. Abundant.

Galathea dispersa. Abundant.

Stenorhynchus Abundant amongst longirostris. $\left\{\begin{array}{r}\text { hydroids and Cel- } \\ \text { hyder. }\end{array}\right.$

Inachus dorsettensis. I laria.

Hyas coarctatus. A few in 39 only.

Eurynome aspera. In 39 only.

Portunus depurator. Abundant except in 77 .

Portunus pusillus. In 39 only.

Atelecyclus heterodon. One or two in 34 only.

Scalpellum vulgare. Frequent at base of hydroids, especially $A n$. tennularia and Halecium.
Mollusca. Living.

Saxicava rugosa, var. arctica. Attached to shells.

Cardium norvegicum. Two or three specimens in 34 and 39. None in 77.

Modiola modiolus. At roots of hydroids, \&c. Small only.

Pecten maximus. Few or none.

,, opercularis. Numerous full-grown specimens and many young on hydroids.

Turritella communis. In 39 only.

Buccinum undatum. Common.

Cypraea europaea. Not very frequent.

Dondersia banyulensis. On Lafoea dumosa, var. robusta.

Lamellidoris oblonga. On Cellaria.

\section{Shells.}

Solen ensis. Not numerous.

Solecurtus candidus. Two in 36 only.

Tapes virginea. Common.

Artemis exoleta.

Cyprina islandica.

Cardium norvegicum.

Pinna pectinata. One or two only.

Pecten maximus. Numerous.

,, opercularis. Numerous.

Dentalium entalis.

Trochus granulatus. Inhabited by Eupagurus Prideauxii.

Buccinum undatum. Inhabited by Eupagurus Bernhardus.

PolyzoA.

$\left.\begin{array}{r}\text { Cellaria sinuosa. } \\ \text { fistulosa. }\end{array}\right\}$ In masses.

,, Johnstoni. Small quantity.

Scrupocellaria scruposa.

Bugula flabellata. In 34 only.

Cellepora avicularis.

$$
, \text { ramulosa. }
$$

Idmonea serpens.

( On hydroids, nu-

Incrusting forms very numerous on shells. For list see Table VI., p. 534.

\section{Tunicata.}

Ascidiella venosa. Few in 39 only.

"scabra. Numerous at base of Sertularella Gayi and of Cellaria.

Compound Ascidian on Cellaria.

Pisces.

Pleuronectes microcephalus (Lemon Dab). One in 77 only.

Solea variegata (Thickback). In 39 . 
Arnoglossus laterna (Scaldback). In 34 only.

Zeus faber (John Dory). One in 77 only. Trigla gurnardus (Grey Gurnard). One in 77 only.

, lineata (Parrot Gurnard). Five specimens in 77 .
Trigla hirundo (Tub Gurnard). One in 77 only.

Callionymus lyra (Dragonet). A few only. Gobius Jeffreysi (Jeffreys' Goby). Many amongst Cellaria, etc.

Rhina squatina (Monk). One small one in 77 only.

\section{Ground V.}

Four miles N.E. $\frac{1}{4}$ N. of Eddystone.

Haul 90 (otter-trawl).

It has been necessary to consider this haul separately from Ground III., as both the bottom-deposit and the fauna show several important differences.

Bottom-deposit. The sand has the following texture:-

$\begin{array}{rllllll}\text { II. } & \text { Coarse Gravel .. } & \ldots & \ldots & 2 \cdot 7 & \text { per cent. } \\ \text { III. } & \text { Medium Gravel } & \ldots & \ldots & 2 \cdot 3 & \\ \text { IV. } & \text { Fine Gravel } & \ldots & \ldots & \ldots & 2 \cdot 4 & " \\ \text { V. } & \text { Coarse Sand } & \ldots & \ldots & \ldots & 3 \cdot 2 & , \\ \text { VI. } & \text { Medium Sand } & \ldots & \ldots & \ldots & 13 \cdot 7 & " \\ \text { VII. } & \text { Fine Sand } & \ldots & \ldots & \ldots & 68 \cdot 8 & " \\ \text { VIII. } & \text { Silt } \ldots & \ldots & \ldots & \ldots & 6 \cdot 8 & \end{array}$

The sand is therefore at the same time coarser and more muddy than that of Ground III.

[90. Average grade of sample, 65561. Percentage of carbonate of lime in whole sample, 22.91. Highest percentage occurs in IV., which contains 57.50 per cent. This is one of the fine-textured deposits, in which VII. constitutes more than 50 per cent. of the whole, and shows the low percentage of carbonate of lime which characterises these fine-texture sands among the present series of samples.

Geologically 90 is parted from all the other samples by a very wide distinction indeed. Roundly speaking, 80 per cent. of the identifiable rock materials are Devonian and only 20 per cent. Triassic. No Eddystone reef material is present. No other sample presents more than 15 per cent. of Devonian rock.

In 90 VI. Foraminifera are comparatively scarce, in 90 VII. they are numerous, 104 individuals were counted in $0 \cdot 13$ grams (2 grains), or 800 per gram. The following species are present, arrangement as before:-Rotalia beccarii, Miliolina seminulum, Lagena orbignyana, Bolivina dilatata, Textularia gramen, Discorbina rosacea, Truncatulina lobatula. In all, seven species.-R. H. W.]

There are few unbroken shells.

Burrowing species. The abundance of Aphrodite aculeata forms a 
characteristic feature of the fauna. The only other burrowing species captured were Astropecten irregularis (one only), Corystes cassivelaunus (one only), Gonoplax angulata (one only, see p. 495).

Fixed species. The hydroid fauna is practically identical with that of Ground III., excepting that Halecium halecinum is entirely absent, and only a small quantity of $H$. Beanii was taken. There was only a little Cellaria, and branched Polyzoa were scarce.

Wandering species. The most characteristic feature is the abundance of Palmipes placenta. In other respects the wandering species are similar to those found on Ground III., excepting that Solaster papposus and Anapagurus laevis were plentiful, whilst Pandalus brevirostris and Buccinum undatum were not taken.

\section{List of Species. Ground V.}

\section{HydrozoA.}

Hydractinia echinata. On shell inhabited by Eupagurus Bernhardus.

Eudendrium ramosum. Very small colony, probably young ramosum, on a piece of leather.

Bougainvillia ramosa. Two good pieces.

Clytia Johnstoni. On Bougainvillia. Common.

Obelia dichotoma. A little.

Lafoea dumosa, var. robusta. Plentiful.

Coppinia arcta. Common on Lafoea dumosa.

Halecium Beanii. Small quantity only.

Sertularella Gayi. A moderate quantity. , polyzonias. Not so plentiful as S. Gayi.

Hydrallmania falcata. A little only.

Antennularia antennina.

Aglaophenia myriophyllum.

Plumularia Catharina. Small quantity on a bit of old leather.

\section{ActinozoA.}

Sagartia parasitica. On Buccinum undatum shell inhabited by Eupagurus Bernhardus.

Adamsia palliata. With Eupagurus Prideauxii.

Alcyonium digitatum. One piece on Chaetopterus tube and one on Pecten opercularis shell.

\section{EChinodermata.}

Astropecten irregularis. One only.

Palmipes placenta. Plentiful. Five specimens.

Solaster papposus. Plentiful.
Asterias glacialis. 4 or 5 specimens. ,, rubens. Many.

Ophiura ciliaris. One.

\section{Polychaeta.}

Aphrodite aculeata. A number of specimens, probably 6 or 8 .

Chaetopterus variopedatus. Piece of tube only.

Sabella (pavonina ?).

Hydroides pectinata. Few.

\section{Crustacea.}

Eupagurus Bernhardus. In Buccinum undatum shell, with Sagartia parasitica.

, $\quad$ Prideauxii, with Adamsia palliata.

Anapagurus laevis. Plentiful.

Porcellana longicornis. Plentiful.

Galathea dispersa. Plentiful.

Stenorhynchus longirostris. Plentiful.

Inachus dorsettensis. Plentiful.

Corystes cassivelaunus. One only (male).

Gonoplax angulata. One only (male).

\section{Mollusca. Living.}

Pecten opercularis. Very few.

Shells.

Pecten opercularis. Few.

\section{PolyzoA.}

$\left.\begin{array}{cc}\text { Cellaria sinuosa. } \\ \text {, fistulosa. }\end{array}\right\}$ A little only of each.

Cellepora avicularia. , On Hydrallmania $, ramulosa. $\}$ falcata.

Pedicellina cernua. On Bougainvillia ramosa.

Schizoporella auriculata. On piece of old leather. 
TUNICATA.

Ascidiella scabra. Two or three young specimens on Inachus dorsettensis.

Fishes.

Trigla pini (Red Gurnard). Two specimens.
Trigla lineata (Parrot Gurnard). Two specimens.

Lophius piscatorius (Angler). One specimen.

Raia clavata (Thornback). One specimen. ,, blanda (Blonde). One specimen.

Ground VI. The South Eddystone Fine Sand.

Hauls. 101 (Dr.) and 102 (Dr. and C.-dr.).

The fauna at hauls 101 and 102 was practically the same, and resembles most nearly that found on Ground III. (the Outer East Sand). In one or two points, however, it resembles also that of the fine sand of Ground II. (the Outer Trawling Ground).

Bottom-deposit. Fine sand. The texture is as follows:-

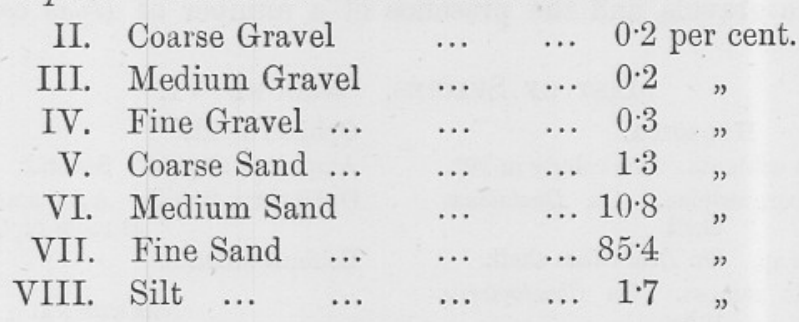

This resembles somewhat closely the sand of haul 91 (Ground III.). (Cf. Table II., p. 525.)

[102. Average grade of sample, 6.849. Percentage of carbonate of lime in whole sample, $14 \cdot 86$. Highest percentage occurs in II., which contains 41.38 per cent., but this grade only represents 0.2 per cent. of whole sample. In 102 VII., which is 85.4 per cent. of whole sample, the percentage of $\mathrm{CaCo}_{3}$ is 13.00 . This is another fine-texture sand. No Eddystone reef material occurs in either 102 II. or 102 III. The latter grade consists, as regarding rock material, of 85 per cent. Trias and 15 per cent. Devonian. 0.13 grams (two grains) of 102 VII. contained 48 Foraminifera, or 369 per gram. The species of Foraminifera present in 102 VI. and VII. are given below in order of frequency:- Rotalia beccarii, Truncatulina lobatula, Miliolina seminulum, Discorbina rosacea, Spiroloculina planulata, Lagena orbignyana, Bulimina pupoides. In all, seven species.-R. H. W.]

Unbroken shells are fairly common.

Burrowing species. Astropecten irregularis is represented by one specimen in 102 only. Dentalium entalis is common, and fresh shells of Cardium echinatum are abundant. Several specimens of Atelecyclus heterodon were also taken.

Fixed species. Cellaria is abundant, and the hydroid fauna is practically the same as that on the sand of Grounds III. and IV., 
excepting that Halecium halecinum is more abundant, corresponding to a considerable abundance of Chaetopterus variopedatus, upon the tubes of which it is generally growing. The tubes of the latter species were generally attached to shells on this ground. Halecium halecinum and Chaetopterus show the influence of the neighbouring coarser Eddystone grounds.

Two other noteworthy fixed species are Chondractinia digitata, fixed to Cardium echinatum shells, and large colonies of Alcyonium digitatum, ${ }^{*}$ which are numerous. In both these features the ground resembles the fine sand of the Outer Trawling Ground (II.), which adjoins it.

Wandering species. Here again the species are practically the same as on Grounds III. and IV., the exceptional features being the presence of several specimens of Ebalia tuberosa, a species abundant on the Eddystone gravels, and the presence of a number of Hyas coarctatus. $†$

\section{List of Species. Ground VI.}

HYDROZOA.

Hydractinia echinata. One colony in 101.

Tubiclava cornucopiae. On Dentalium shell.

Perigonimus sp. On Dentalium shell.

Bougainvillia ramosa. On Chaetopterus tube.

Lafoea dumosa, var. robusta.

Campanularia verticillata. One or two colonies.

Halecium halecinum. Plentiful.

Sertularella Gayi. Plentiful.

Hydrallmania falcata. One piece only in 101.

$\left.\begin{array}{c}\text { Antennularia antennina. } \\ , \text { ramosa. }\end{array}\right\}$ Plentiful.

Aglaophenia myriophyllum. One piece only, with Scalpellum vulgare on it.

Plumularia pinnata.

", Catharina. On Chaetopterus tube.

ActinozoA.

Adamsia palliata. With Eupagurus Prideauxii.

Chondractinia digitata. On Cardium echinatum shells. Two or three specimens only.

Alcyonium digitatum. In quantity; large colonies.

ECHiNodermata.

Astropecten irregularis. One only, in 102.

Asterias glacialis. $, rubens. $\}$ Several of each.

Ophiura ciliaris. A few only.

* Cf. p. 457 .
Ophiura albida.

Amphiura elegans. Several.

Ophiothrix fragilis. A few small ones only at roots of Cellaria.

Echinus miliaris.

\section{Nemertina.}

Carinella annulata.

Tetrastemma dorsale.

Lineus bilineatus.

\section{Polychaeta.}

Lagisca propinqua. Two specimens only. Nereis procera. Five or six specimens.

Typosyllis alternosetosa. Several specimens.

Polydora caeca. Several specimens.

Chaetopterus variopedatus. Fairly abundant.

Nicolea venustula. One in 101 only.

Thelepus. Many.

Sabella.

Sabellaria spinulosa. Several.

Dasychone bombyx. Four specimens.

Serpula vermicularis. Tubes only.

Hydroides pectinata. Several.

Potamoceros triqueter. Tubes only.

\section{Crustacea.}

Eupagurus Bernhardus. A few in Buccinum undatum shells.

, Prideauxii. Not plentiful. With Adamsia palliata.

Anapagurus laevis. In shell of Tornatella fasciata, and in Turritella communis shell.

† Cf. p. 490. 
Porcellana longicornis. Plentiful.

Galathea dispersa. Plentiful.

Stenorhynchus longirostris. Dressed with hydroids, etc. (Plumularia pinnata).

Inachus dorsettensis. Dressed with barnacles, compound ascidians, sponges, and Scrupocellaria.

Hyas coarctatus. A few females, breeding, dressed with barnacles, compound ascidians, Ascidiella scabra, Scrupocellaria, and Bicellaria.

Eurynome aspera. In 101 only, one or two specimens.

Portunus depurator. Several. Females with eggs.

, pusillus. Few.

Atelecyclus heterodon. Several.

Ebalia tuberosa. Few only.

Balanus. On Hyas coarctatus.

Scalpellum vulgare. On Aglaophenia myriophyllum.

\section{Mollusca. Living.}

Pecten tigrinus. One specimen in 101. , opercularis. A few only.

Chiton asellus.

Dentalium entalis. A few.

Buccinum undatum.
Doto fragilis.

,, coronata.

", pinnatifida.

Archidoris tuberculata.

Triopa claviger.

Polycera quadrilineata.

\section{Shells.}

Psammobia ferroensis. One or two only.

Tapes virginea. Plentiful.

Cyprina islandica. A few.

Cardium echinatum. Shells numerous.

Nucula nucleus.

Pinna pectinata. One or two only.

Pecten maximus.

, opercularis. Many.

Dentalium entalis.

\section{Polyzoa.}

Cellaria sinuosa. fistulosa. $\}$ In quantity.

Scrupocellaria scruposa.

Bicellaria ciliata. On Hyas coarctatus and on Sertularella Gayi.

Bugula avicularia. On Sertularella Gayi. Cellepora ramulosa. In quantity on hydroids.

\section{TUNicata.}

Ascidiella scabra. Fairly common.

Compound Ascidian on Sertularella Gayi.

\section{Ground VII. The South Eddystone Intermediate Sand.}

Hauls. 75 (Dr.), 76 (Dr.), 70 (Dr.), 71 (Dr.), 54 (Dr.), 69 (Dr.), 38 (Dr.), 80 (Dr.), 79 (Dr.), 100 (Dr.), 32 (Dr.), 109 (Dr. and C.-dr.).

The hauls combined under the present heading vary somewhat individually, but the prevailing features are the same, and indicate a predominant sand fauna mixed with a considerable number of species characteristic of the gravel grounds which lie immediately to the north, especially Ground XIV.

Bottom-deposit. This is probably fine sand over the whole ground, though the more northerly hauls may have been taken partly on gravel and partly on fine sand. Gravel was noted at the time in haul 76.

A sample with the canvas bag taken at haul 109 had the following texture :-

$\begin{array}{rllllll}\text { III. } & \text { Medium Gravel } & \ldots & \ldots & \ldots & 0.01 & \text { per cent. } \\ \text { IV. } & \text { Fine Gravel } & \ldots & \ldots & \ldots & 0 \cdot 2 & , \\ \text { V. } & \text { Coarse Sand } & \ldots & \ldots & \ldots & 1 \cdot 2 & " \\ \text { VI. } & \text { Medium Sand } & \ldots & \ldots & \ldots & 24 \cdot 0 & " \\ \text { VII. } & \text { Fine Sand } & \ldots & \ldots & \ldots & 72 \cdot 7 & " \\ \text { VIII. } & \text { Silt } \quad \ldots & \ldots & \ldots & \ldots & 1 \cdot 9 & "\end{array}$


[109. Average grade of sample, 6.749. Percentage of carbonate of lime in whole sample, $30 \cdot 15$.

The following are the species of Foraminifera in grades VI. and VII. in order of frequency :-Rotalia beccarii, Miliolina seminulum, Textularia gramen, Truncatulina lobatula, Discorbina rosacea, Textularia agglutinans, Miliolina bicornis, Lagena sulcata, Bolivina dilatata.-R. H. W.]

Shells were plentiful in all the hauls, and in hauls $32,75,79$, and 100 a number of stones were obtained.

Fauna. The ground as a whole is barren, and in no haul were many specimens taken, with the exception of haul 100 .

Burrowing species. A few Astropecten irregularis were present, but the species was not at all common. Dentalium entalis was present in the sample of sand, and several bivalve molluses were taken in individual hauls, as will be seen from the list of the fauna.

Fixed species. Of species which usually fix themselves in fine sand the following occur on this ground: Antennularia antennina and ramosa, Aglaophenia myriophyllum, and Cellaria fistulosa and sinuosa, the two latter in considerable abundance. The other representatives of the fixed fauna include species which are typical of the gravels to the north and also those typical of the fine sand to the south. Of the former are Polycarpa varians and Chaetopterus variopedatus, with Halecium halecinum, H. Beanii and Plumularia Catharina; of the latter Sertularella Gayi, Bougainvillia ramosa, and Ascidiella scabra.

Wandering species. These are not abundant, and are of kinds found both on the gravel and on the fine sand grounds. A noteworthy feature, characteristic of the ground, is the presence in almost every haul of Palmipes placenta.

\section{List of Species. Ground VII.}

Foraminifera.

Truncatulina lobatula. On Cellaria and hydroids.

\section{Porifera.}

Suberites domuncula. Fairly common, inhabited by Eupagurus cuanensis.

Cliona celata. Common, boring shells.

\section{HydrozoA.}

Hydractinia echinata. In 76 only, on shell inhabited by Eupagurus Bernhardus.

Eudendrium ramosum. Fairly plentiful.

, capillare. Scarce.

,, sp. Scarce.

Bougainvillia ramosa. Not uncommon.

Clytia Johnstoni. Common, on hydroids, ete.
Obelia dichotoma. In 32 only.

Campanularia Hincksii. Common, on hydroids and shells.

Lafoea dumosa, var. robusta. Frequent. Creeping variety also abundant on hydroids and Cellaria.

Calycella fastigiata. Recorded in 75 only. Halecium halecinum. Plentiful on Chaetopterus tubes and on shells.

, Beanii. Not so plentiful as H. halecinum.

" labrosum. Recorded in 75 only.

Sertularella Gayi. Generally moderately plentiful. In hauls 69 , 71 , and 109 small pieces only.

,$\quad$ polyzonias. Scarce.

Sertularia argentea. In 79 and 32 only. Not abundant. 
Hydrallmania falcata. Frequent, but not abundant in any haul.

Antennularia antennina. Frequent.

$$
\text { ,, ramosa. In } 109 \text { only. }
$$

Aglaophenia myriophyllum. In five hauls, not abundant.

Plumularia pinnata. Common.

,, setacea. In 32 only.

, Catharina. In 100 and 109 only, abundant on Chaetopterus tubes.

\section{ActinozoA.}

Sagartia parasitica. On Buccinum undatum shell inhabited by Eupagurus Bernhardus. One specimen in 75 only.

Adamsia palliata. On shells inhabited by Eupagurus Prideauxii. Not numerous.

Paraphellia expansa. One in 109 only.

Caryophyllia Smithii. Not frequent.

Alcyonium digitatum. Generally small colonies only. In 100 larger colonies on stones.

Sarcodictyon catenata. In 100 only, where it was present in large quantities on stones.

\section{Echinodermata.}

Cucumaria pentactes. In 100 only, attached to stones.

, lactea. In 79 only.

Astropecten irregularis. One or two in 69,79 , and 109 only.

Palmipes placenta. Frequent, but only one or two in each haul.

Solaster papposus. Not numerous.

Henricia sanguinolenta. One or two in 71 and 75 only.

Asterias glacialis. Frequent but not numerous.

„, rubens. Not numerous.

Ophiura ciliaris. Few only.

, albida. Few only.

Ophiactis Balli. Generally present.

Ophiothrix fragilis. Not generally plentiful. Most numerous in 76 and 109.

Amphiura filiformis. One in 109.

Echinus acutus. One in 54 only.

," miliaris. Common.

, esculentus. Not abundant.

Echinocyamus pusillus. Recorded in 75 and 109 only.

Spatangus purpureus. In 38 only, caught on the tangles attached to the dredge.
Nemertina.

Carinella superba.

Lineus bilineatus.

Micrura purpurea.

Cerebratulus fuscus.

\section{Polychaeta.}

Lepidonotus squamatus. In two hauls only.

Lagisca propinqua. Not uncommon.

", rarispina. Two specimens recorded in 70 only.

Polynoe scolopendrina. In 54 only.

Harmothoë imbricata. Recorded in 54 only.

Evarne impar. One or two in 54 and 70 only.

Hyalinoecia tubicola. Not frequent.

Arabella geniculata. One in 100 only recorded.

Nereis procera. Occasional specimens. Several in 100 .

Eulalia viridis. Recorded in 54 only.

Chaetopterus variopedatus. Constantly present, but not in large numbers.

Pectinaria auricoma. Occasional specimens.

Polymnia nebulosa. One in 100 only.

Nicolea venustula. Recorded in 54 only.

Thelepus. Abundant.

Amphitrite gracilis. Recorded in 32 only.

Terebellid tubes.

Sabella (pavonina?).

Filograna implexa. Attached to shells. Frequent.

Dasychone bombyx. Abundant.

Protula tubularia. A few only.

Serpula vermicularis. Attached to shells, ete.

Hydroides pectinata.

Potamoceros triqueter.

\section{Crustacea.}

Pandalus brevirostris. Few only amongst Cellaria.

Eupagurus Bernhardus. Not frequent. As usual in Buccinum undatum shells.

Prideauxii. Shells covered by Adamsia palliata. Not frequent.

, cuanensis. Not frequent. Covered with Suberites domuncula.

Anapagurus laevis. Not frequent.

Porcellana longicornis.

Galathea dispersa. Frequent. 
Stenorhynchus longirostris. Frequent, but not abundant in any one haul.

Inachus dorsettensis. Frequent, but not abundant in any one haul.

Eurynome aspera. Frequent, but only two or three in a haul.

Cancer pagurus. One in 75 .

Portunus pusillus. In 38 only.

Atelecyclus heterodon. In 38 and 100 only. Not numerous.

Ebalia tuberosa. In 38 only.

Balanus crenatus. On Pecten opercularis. Scalpellum vulgare. Attached to Halecium and Antennularia.

\section{Mollusca. Living.}

Saxicava rugosa, var. aretica. Not frequent. Attached to shells and base of hydroids. Pandora obtusa. One specimen in 75
only.

Venus verrucosa. One in 76 only.

, casina. One in 79 only.

, ovata. In 76 only.

Circe minima. In 76 only.

Cardium echinatum. One in 75 only.

, norvegicum. One or two in 79 and 100 only.

Kellia suborbicularis. In 80 only.

Modiola modiolus.

Nucula nucleus. One or two in 76 only.

, nitida. One in sample of sand of 109.

Lima Loscombii. In 75 only.

Pecten tigrinus. One or two in 38 and 80 only.

,, maximus. Generally several specimens.

, opercularis. Generally not a large number; most abundant in 54 .

Anomia ephippium. , Generally on Pec,, patelliformis. I ten opercularis.

Chiton asellus. On shells and stones.

Dentalium entalis. In sample of sand from 109

Emarginula reticulata.

Lamellaria perspicua. In 75,80 , and 109.

Buccinum undatum. Generally present.

Cypraea europaea. In 75 only.

Proneomenia aglaopheniae. In 100 and 109 on stem of Aglao. phenia myriophyllum.
Doto fragilis.

,, pinnatifida.

,, coronata.

Doris maculata. One specimen in 100 .

Lamellidoris oblonga. On Cellaria.

$$
\text { Shells. }
$$

Lyonsia norvegica. In 76 only.

Solecurtus candidus. In 100 only.

Psammobia ferroensis. In 75 and 80 only.

Lutraria elliptica.

Tapes virginea. Frequent.

Artemis exoleta.

Cyprina islandica.

Cardium echinatum. Frequent.

,, norvegicum. Frequent.

Pectunculus glycimeris. A few small only.

Pinna pectinata. Few only.

Pecten tigrinus.

" maximus. Numerous.

,, opercularis. Numerous.

Dentalium entalis.

Turritella communis. Few.

Aporrhais pes-pelecani. Few.

Fusus islandicus. One in 80 only.

\section{PolyzoA.}

Cellaria sinuosa. Plentiful.

, fistulosa. Plentiful.

Bicellaria ciliata. Frequent, attached to Cellaria and hydroids.

Scrupocellaria scruposa. Abundant on shells and at base of hydroids, etc.

Bugula avicularia. Few only.

Cellepora avicularis. On hydroids. Common.

, ramulosa. On hydroids. Common.

Crisea eburnea. Not frequent.

Pedicellina cernua. In 100 only.

Alcyonidium gelatinosum. In 100 only, on stones.

Incrusting Polyzoa numerous, For list see Table VI., p. 534.

\section{Tunicata.}

Molgula simplex. On Chaetopterus tube in 100 .

Polycarpa varians. Numerous.

Ascidiella seabra. Few only.

Ciona intestinalis. Few only.

Corella larvaeformis. On Cellaria in 75 and 109.

\section{Fishes,}

Lepadogaster bimaculatus. Single specimens in several hauls. 


\section{Ground VIII.}

Eddystone S.E. $\frac{1}{2}$ S., about one mile distant.

Haul 48, (Dr.) with 89 B (?) C-dr.

Haul 48 resembles in all the characteristic features of its fauna the hauls made on the fine sand of Ground VII., and it is therefore necessary to separate it from Ground XIV., which adjoins it on the southern side. As in the case of Ground VII. the fauna is clearly very much influenced by that of XIV., but the abundance of Cellaria, the nature of the hydroid fauna, the presence of Palmipes placenta, all point to a fine sand deposit. It is not unlikely that the dredge passed over more than one kind of bottom-deposit.

That a fine sand deposit does exist in this neighbourhood was shown by a sample taken with the canvas dredge at the conclusion of haul 89 . The latter haul (Ground X., see p. 417) was composed almost entirely of Ophiothrix fragilis, but when at the end of it the canvas dredge was used, it came up full of fine sand, and with no specimens of the ophiurid. This sample has been numbered $89 \mathrm{~B}$. That the ophiurid ground had been passed when it was obtained I have no doubt, as in all cases where the canvas dredge has been used on grounds where Ophiothrix was very abundant, both on the Eddystone grounds and in other localities, a very large number of specimens of the species came up with the sample of deposit, and the latter was always muddy gravel.

The composition of the sample $89 \mathrm{~B}$ is therefore given here:-

$\begin{array}{rllllll}\text { II. } & \text { Coarse Gravel } & \ldots & \ldots & \ldots & 1 \cdot 3 & \text { per cent. } \\ \text { III. } & \text { Medium Gravel } & \ldots & \ldots & \ldots & 1 \cdot 5 & \\ \text { IV. } & \text { Fine Gravel } & \ldots & \ldots & \ldots & 2 \cdot 8 & " \\ \text { V. } & \text { Coarse Sand } & \ldots & \ldots & \ldots & 6 \cdot 3 & " \\ \text { VI. } & \text { Medium Sand } & \ldots & \ldots & \ldots & 29 \cdot 2 & " \\ \text { VII. } & \text { Fine Sand ... } & \ldots & \ldots & \ldots & 56 \cdot 8 & " \\ \text { VIII. } & \text { Silt } \quad \ldots & \ldots & \ldots & \ldots & 2 \cdot 0 & \end{array}$

[89B. Average grade of sample, 6.386. Percentage of carbonate of lime in whole sample, 48.61 . Highest percentage occurs in VI., which contains $62 \cdot 73$. This is one of the fine-texture deposits, in which the percentage of grade VII. to whole sample rises above 50 per cent.

In $89 \mathrm{~B}$ VI. Foraminifera were numerous, thirty-eight individuals being counted in $0 \cdot 16$ grams ( $2 \frac{1}{2}$ grains), or 237 per gram. In $89 \mathrm{~B}$ VII. Foraminifera were very numerous. The following are the species found, in order of frequency:-Rotalia beccarii, Miliolina seminulum, Truncatulina lobatula, Textularia gramen, Textularia agglutinans, Discorbina rosacea, Planorbulina mediterranensis, Lagena sulcata, Miliolina trigonula, Miliolina bicornis. In all, ten species.-R. H. W.]

No shells were present in the sample. 


\section{List of Species. Ground VIII.}

HYDROZOA.

Campanularia Hincksii.

Lafoea dumosa.

Halecium halecinum.

Sertularella Gayi.

Sertularia argentea. A few young colonies. Antennularia antennina.

Aglaophenia myriophyllum. Fairly common.

\section{ActinozoA.}

Alcyonium digitatum. One or two pieces only.

\section{Echinodermata.}

Palmipes placenta.

Henricia sanguinolenta. One or two only. Asterias glacialis. One or two. , rubens. One only.

Ophiura ciliaris. Many.

$$
\text { , albida. One. }
$$

Ophiocoma nigra. A moderate number.

Ophiothrix fragilis. A moderate number.

Echinus esculentus.

Spatangus purpureus.

\section{Polychaeta.}

Hyalinoecia tubicola.

Chaetopterus variopedatus. Few only.

Pectinaria auricoma. One or two only.

Thelepus.

Protula tubularia. Few only.

\section{Crustacea.}

Eupagurus Prideauxii.

Anapagurus laevis.

Porcellana longicornis.

Galathea dispersa.

Stenorhynchus longirostris.

Inachus dorsettensis.

Eurynome aspera.
Portunus depurator.

,, pusillus.

Ebalia tumefacta.

,, tuberosa.

\section{Mollusca. Living.}

Pecten maximus.

,, opercularis. A few adults. Young on hydroids common.

Aporrhais pes-pelecani. One living specimen.

Ovula patula. One or two only.

Proneomenia aglaopheniae. On Aglaophenia myriophyllum.

\section{Shells.}

Eulima. With Anapagurus laevis.

Lutraria elliptica.

Cardium echinatum. ,, norvegicum.

Pecten opercularis.

Dentalium entalis.

\section{PolyzoA.}

Cellaria sinuosa. In quantity.

Bugula avicularia.

,, flabellata.

Scrupocellaria scruposa. In quantity on Terebellid tubes.

Bicellaria ciliata. On Sertularella Gayi.

Cellepora avicularis.

," ramulosa. ( Common on

Idmonea serpens. I hydroids.

Alcyonidium gelatinosum. A large piece.

Pedicellina cernua.

Lichenopora hispida. IOn Pecten oper-

Mucronella ventricosa. $\}$ cutaris shell.

Tunicata.

Ascidiella scabra.

\section{Ground IX. The West Eddystone Coarse Gravel.}

Hauls. 93 (Dr.) and 94 (C.-dr.).

These two hauls show the fauna of the West Eddystone coarse gravels in its most typical form, without admixture of the fine sand fauna, and the description of the ground will therefore be given in some detail. 
Bottom-deposit. A mixture of coarse gravel with fine sand. The texture is shown by the percentage composition as follows:-

$\left.\begin{array}{rlrrrr}\text { I. } & \text { Stones .. } & \ldots & \ldots & 0.9 & \text { per cent. } \\ \text { II. } & \text { Coarse Gravel } & \ldots & \ldots & 44.4 & \\ \text { III. } & \text { Medium Gravel... } & \ldots & 14 \cdot 0 & \\ \text { IV. } & \text { Fine Gravel } & \ldots & \ldots & 10 \cdot 2 & ,\end{array}\right\} 69.5$ per cent.

[94. Average grade of sample, 3.66. Percentage of carbonate of lime in whole sample, $17 \cdot 71$. Percentage in each grade except I., which may be neglected, uniformly low; highest in VI. at $29 \cdot 14$ per cent. In 94 II. 75 per cent. by weight of the gravel is Triassic, 9 per cent. derived from the Eddystone reef, 16 per cent. is Devonian. In 94 III. 69 per cent. Triassic, 18 per cent. Eddystone reef, 13 per cent. Devonian. Some amorphous silica, probably flint and cretaceous, is present in this and many other samples, and is referred to elsewhere. (p. 384.) Foraminifera are fairly numerous in VII. and numerous in VI. The following species are present, following order of frequency:Rotalia beccarii, Truncatulina lobatula, Discorbina rosacea, Miliolina seminulum, Planorbulina mediterranensis, Textularia gramen, Bulimina pupoides, Lagena striata, Spiroloculina planulata, Miliolina bicornis, Lagena apiculata. In all, eleven species.-R. H. W.]

Shells were very numerous on this ground. (See list, p. 416.) The fauna is varied and abundant, the nature of the ground offering great advantages, especially to fixed species.

Burrowing species. Ebalia tumefacta and Ebalia tuberosa* were very numerous, as well as small specimens of Atelecyclus heterodon. The other burrowing animals were one small specimen of Astropecten irregularis and one specimen of Cardium norvegicum.

Fixed species. Hydroids which root themselves directly in the bottom-deposit are represented by one or two specimens of Antennularia antennina only, and Cellaria is also practically absent, one small piece of $C$. fistulosa only having been obtained.

One of the chief characteristics of the ground, and one which has a marked influence on its general fauna, is the presence of large numbers of Chactopterus variopedatus. The large, leathery tubes of these worms are found either attached to shells, joined together into masses of considerable size, or, less frequently, apparently living freely

* Mr. Garstang tells me that he has observed the burrowing of Ebalia in gravel in the Laboratory. They do not burrow deeply, but remain with the front part of the carapace just above the surface.

NEW SERIES,-VOL. V. NO. 4. 
buried in the gravel. The tubes form excellent fixing places for other species of animals, more especially for the hydroid Halecium halecinum, which is exceedingly abundant and characteristic of this ground. Plumularia Catharina, P. pinnata, and Halecium Beanii are also commonly found attached to the tubes of the same worm.

Only one or two small pieces of Sertularella Gayi, which was the abundant hydroid on the fine sand, were taken here. Another characteristic species is the ascidian Polycarpa varians, which is very numerous, and seems to be attached directly to the gravel, since pieces of gravel and shell are generally fixed all over its base when it comes up in the dredge.

Caryophyllia Smithii is abundant on shells, especially on Pecten shells, associated with the barnacle Pyrgoma anglicum. Alcyonium digitatum is found only in the form of small colonies on living Pecten opercularis. One specimen of Paraphellia expansa was obtained.

Amongst other fixed species Anomia ephippium, A. patelliformis, Scrupocellaria scruposa are common attached to the Chactopterus tubes or to shells, Bicellaria ciliata on Halecium, and incrusting polyzoa on shells.

Wandering species. Pecten opercularis is numerous, and with it Asterias rubens and Asterias glacialis. Pecten maximus is also common, and is a characteristic species of these coarse gravel grounds, though by no means so numerous as $P$. opercularis. Ophiothrix fragilis, of which only a few small specimens at the roots of hydroids and Cellaria were seen on the fine sand, is here very numerous. Ophiura ciliaris is present in considerable numbers, but is by no means so plentiful as O. fragilis. Ophiura albida, which was never taken on the fine sand, is common, as well as Ophiactis Balli, a small species which hides away in crevices amongst shells and Chaetopterus tubes. Echinus acutus and esculentus are both taken.

The hermit crabs Eupagurus Bernardus and E. Prideauxii are plentiful, the former associated with Hydractinia echinata, the latter with Adamsia palliata. Anapagurus laevis is very abundant, so much so that it becomes one of the peculiar features of the ground. Inachus dorsettensis is plentiful, covered with sponges, \&c. Stenorhynchus longirostris is less abundant. Eurynome aspera was represented by several specimens. Porcellana longicornis and Galathea dispersa are exceptionally numerous. The polychaete fauna is abundant and varied, the abundance of Hyalinoecia tubicola and the presence of Hermione hystrix being characteristic of the coarse deposit.

Living specimens of Turritella communis, a species only represented by single specimens on other grounds, were here numerous. Buccinum undatum was present, and single specimens of Lima Loscombii and 
Trochus granulatus were seen. The small sucker, Lepadogaster bimaculatus, was the only fish taken.

\section{List of Species. Ground IX.}

Foraminifera.

Truncatulina lobatula. On hydroids.

Porifera.

Cliona celata. Boring shells of Pecten maximus and Pecten opercularis.

HYDrozoA.

Hydractinia echinata. On shell inhabited by hermit crab.

Eudendrium ramosum. Small colony, growing on Ascidiella scabra.

Campanularia Hincksii. Large variety, growing on Pecten opercularis shell.

Halecium halecinum. Very plentiful on tubes of Chaetopterus and on shells, especially Pecten maximus.

Halecium Beanii. Several pieces.

Sertularella Gayi. One or two pieces only. Hydrallmania falcata. A little only, growing on Cyprina Islandica shell.

Antennularia ramosa. One or two pieces only.

Plumularia pinnata, On Chaetopterus tubes, fairly plentiful.

, $\quad$ setacea. Small variety, with gonophores.

" Catharina. On Chaetopterus tubes, common, both ordinary and green variety.

ACTINOZOA.

Caryophyllia Smithii. Common on old shells of Pecten maximus.

Adamsia palliata. With Eupagurus Prideauxii.

Paraphellia expansa. One specimen.

Alcyonium digitatum. Small colonies on Pecten opercularis only.

\section{ECHINODERMata.}

Astropecten irregularis. One small specimen.

Solaster papposus. One only.

Asterias glacialis. $\}$ Plentiful.

, rubens. Many.

,, albida. Many.

Ophiactis Balli. Plentiful.

Ophiocoma nigra. One large one and one small one only seen.
Ophiothrix fragilis. Plentiful.

Echinus acutus. Two specimens.

, miliaris. A few.

, esculentus. Two specimens.

Carinella superba.

Nemertina.

Micrura fasciolata.

", purpurea.

Tetrastemma (? flavidum).

\section{Polychaeta.}

Hermione hystrix. One specimen.

Lepidonotus squamatus. Very many specimens.

Lagisca propinqua. Very many.

Halosydna gelatinosa. One only.

Hyalinoecia tubicola. Many.

Chaetopterus variopedatus. Very abundant, attached to shells and to gravel.

Polymnia nebulosa. Three specimens.

Thelepus. Very abundant.

Terebellid tubes.

Sabella (pavonina?).

Filograna implexa. Small pieces on Pecten opercularis shells.

Dasychone bombyx. Abundant.

Serpula vermicularis. Fairly plentiful, attached to shells.

Hydroides pectinata.

Potamoceros triqueter.

\section{Crustacea.}

Pandalus brevirostris. Few only.

Eupagurus Bernhardus. Several in Buccinum undatum shell.

, Prideauxii. With Adamsia palliata. In Trochus granulatus shell.

Anapagurus laevis. Common in the following shells, Turritella communis, Natica nitida, Mangeliagracilis, and Nassa incrassata.

Porcellana longicornis. Plentiful.

Galathea dispersa. Plentiful.

Stenorhynchus longirostris. Common. Less plentiful than
Inachus.

Inachus dorsettensis. Common.

Eurynome aspera. A number of specimens.

Portunus̀ pusillus. One or two. 
Atelecyclus heterodon. Many small specimens.

$\left.\begin{array}{c}\text { Ebalia tumefacta. } \\ \text {,y tuberosa. }\end{array}\right\}$ Very numerous.

Balanus, $s p$. Common on shells.

Scalpellum vulgare. Attached to base of Halecium halecinum.

Pyrgoma anglicum. Associated with Caryophyllia Smithii.

\section{Moludsca. Living.}

Saxicava rugosa, var. aretica. On Pecten maximus shell.

Cardium norvegicum. One living only.

Modiola modiolus. Small, on Pecten opercularis shells.

Lima Loscombii. One living.

Pecten maximus. Many.

,, opercularis. Many.

Anomia ephippium. (Many small ones ,, patelliformis. $\}$ on shells.

Chiton asellus. On Pecten shells.

Pileopsis hungaricus. One specimen.

Trochus granulatus. One living.

Turritella communis. Many.

Buccinum undatum. Several specimens and spawn.

Doto fragilis. Abundant on Halecium halecinum. Shells.

Lutraria elliptica.

Tapes virginea. Many.

Venus verrucosa. Few.

, ovata. Many.

Cyprina islandica. A few only.

Cardium norvegicum. Numerous.

Pinna pectinata. One or two only.
Pecten tigrinus. Few.

" maximus. Plentiful.

, opercularis. Plentiful.

Trochus granulatus. Inhabited by Eupagurus Prideauxii and covered with Adamsia palliata.

Turritella communis. Numerous, many inhabited by Anapagurus laevis.

Aporrhais pes-pelecani. One shell.

Natica nitida, Shells inhabited by Anapagurus laevis.

Nassa incrassata. Shells inhabited by Anapagurus laevis.

Mangelia gracilis. Shells inhabited by Anapagurus laevis.

Trophon muricatus. One shell.

\section{PolyzoA.}

Cellaria fistulosa. One piece only.

Scrupocellaria scruposa. In quantity on shells, on Chaetopterus tubes, and on Polycarpa varians.

Bicellaria ciliata. On Halecium Beanii.

Incrusting forms fairly common on shells. For list see Table VI., p. 534.

\section{TUnicata.}

Polycarpa varians. Many, attached to shells or to gravel.

Ascidiella scabra. At base of stem of Antennularia antennina and Sertularella Gayi.

Botryllus, $s p$.

Fishes.

Lepadogaster bimaculatus. One or two only.

\section{Ground X. The OpHIothrix FrAGILIS Ground.}

Hauls. 42 (Dr.), 55 (Dr.), 89 (Dr.), 95 (Dr.), and 96 (C.-dr.).

This ground lies to the west and north-west of the Eddystone, between the medium gravel of Ground XIV. and the coarse gravel of Grounds IX. and XI.

Bottom-deposit. Coarse gravel and muddy sand. The texture of the sample at haul 96 was :-

\begin{tabular}{|c|c|c|c|c|c|}
\hline II. & Coarse Gravel & & ... & $\ldots 35 \cdot 3$ & er cent \\
\hline III. & Medium Gravel & & $\ldots$ & ... $14: 3$ & , \\
\hline IV. & Fine Gravel & .. & $\ldots$ & $9 \cdot 1$ & " \\
\hline V. & Coarse Sand & . & $\ldots$ & $8 \cdot 9$ & " \\
\hline VI. & Medium Sand & .. & $\ldots$ & $\ldots 16 \cdot 3$ & " \\
\hline VII. & Fine Sand & . & ... & $\ldots 12 \cdot 1$ & $"$ \\
\hline VIII. & Silt $\quad$. & & $\ldots$ & $\ldots \quad 3 \cdot 9$ & ", \\
\hline
\end{tabular}


[96. Average grade of sample, 4.081. Percentage of carbonate of lime in whole sample, 33.18. Highest percentage occurs in IV., which contains 60.08 per cent. In 94 II. the gravel consists of Trias, 77 per cent.; Eddystone reef, 13 per cent.; Devonian, 10 per cent. In 94 III. the proportions are, Trias, 69 per cent.; Eddystone reef, 18 per cent.; Devonian, 13 per cent. In 96 VII. Foraminifera are numerous. The following species occur in VI. and VII., following order of frequency :Rotalia beccarii, Textularia gramen, Miliolina seminulum, Truncatulina lobatula, Spiroloculina planulata, Lagena sulcata, Textularia agglutinans, Biloculina ringens, Miliolina bicornis, Polymorphina lactea, Discorbina rosacea. In all, eleven species.-R. H. W.]

Shells were numerous. For list see p. 418.

The fauna of this ground is characterised by the very great abundance of Ophiothrix fragilis, which occurs almost to the exclusion of every other species. The dredge comes up nearly full of these ophiurids. In haul 89 the only other living species taken was Ophiocoma nigra, of which there were a few large specimens. In the remaining hauls a few specimens of other species were obtained, but generally not more than one or two in each. These species, as will be seen from the following list, consist of immigrants from the grounds on either side, that is, from the medium gravel of Ground XIV. and from the coarse gravel of Ground IX. Ground X. may be regarded as a great centre of distribution of Ophiothrix fragilis, from which it extends on all sides on to the surrounding grounds (Chart VIII.). The ophiurids were found to be feeding on the fine silt, of which there is a somewhat high percentage in the bottom-deposit.

\section{List of Species. Ground X.}

\section{A. Haul 89.}

Echinodermata.

Ophiothrix fragilis. Dredge half full. Ophiocoma nigra. A few, large.

B. Hauls $42,55,95$.

(B). HydrozoA.

Eudendrium, sp. Small sp. not E.capillare, in 55 only, growing on Hydrallmania, which was fixed to a stone.

Campanularia Hincksii.

Lafoea dumosa, var. robusta. In 55 only. Halecium halecinum. Not plentiful. Most abundant in 55 .

Halecium Beanii. Not plentiful.

Sertularella Gayi. Not plentiful. Largest quantity in 55 .

Hydrallmania falcata. In 55 only, growing on a stone.
Mollusca. Shells.

Pecten opercularis, A few only.
Antennularia antemnina. Not plentiful. ramosa. One piece in 42
only.

Aglaophenia tubulifera. In 55 only, growingon Polycarpavarians.

Plumularia Catharina. Green variety in 55 only.

(B). ActinozoA.

Alcyonium digitatum. Young colonies on Pecten opercularis. One or two only.

Sareodictyon catenata. A small quantity in 95 only. 
Caryophyllia Smithii. Fairly plentiful on shells.

Adamsia palliata. With Eupagurus Prideauxii in 42 only.

\section{(B). Echinodermata.}

Porania pulvillus. One specimen in 42 only.

Solaster papposus. A few small.

Asterias glacialis.
rubens. One or two only.

Ophiura ciliaris. One or two specimens in each haul.

Ophiactis Balli, Few.

Ophiocoma nigra. One in 42 , one small one in 95 .

Ophiothrix fragilis. In very large numbers.

Echinus acutus, One in 42 only.

," miliaris.

" esculentus. In 55 . One small one in 42 .

Spatangus purpureus. One or two in each haul.

(B). Nemertina.

Drepanophorus rubrostriatus. In 55 only.

(B). Polychaeta.

Hermione hystrix. One in 42 only.

Lepidonotus squamatus. One in 95 only.

Lagisea propinqua. One in 95 only.

Hyalinoecia tubicola. One in 95 only.

Chaetopterus variopedatus. A few specimens in each haul.

Pectinaria auricoma. One in 42 only.

Nicolea venustula. In 55 only.

Terebellid tubes.

Sabella (pavonina ?). One or two in 95 .

Dasychone bombyx. In 55 only.

Protula tubularia. Few only.

Serpula vermicularis. Few only.

Hydroides pectinata. Few only.

\section{(B). Crustacea.}

Eupagurus Bernhardus. One or two in 95 only.

, Prideauxii. One or two in 42 only.

Porcellana longicornis.

Galathea dispersa. In 55 only.

Stenorhynchus longirostris. In 55 only (the haul in which hydroids were plentiful).

Portunus pusillus. Not numerous.

Atelecyclus heterodon. Two or three in a haul.

Ebalia tumefacta. Few only. None , tuberosa. $\}$ in 55 .
Balanus crenatus. On Pecten opercularis. Scalpellum vulgare. On Halecium halecinum in 55 only.

(B). Mollusca. Living.

Astarte sulcata. Plentiful in 95 only.

Cardium norvegicum. In 42 only.

Kellia suborbicularis. In 42 only, in fine mud in bivalve molluse shells.

Pecten maximus. A few in each haul. , operenlaris. Few only.

Anomia ephippium. (Chiefly on Pecten , patelliformis. $\}$ opercularis.

Chiton asellus.

Pileopsis hungaricus. On Pecten opercularis in 95 .

Emarginula reticulata. One or two only. Aporrhais pes-pelecani. One in 55 only. Buccinum undatum. Few only.

Dondersia banyulensis. On Lafoea dumosa, var. robusta in 55 only.

Shells.

Lutraria elliptica.

Tapes virginea.

Venus ovata.

Astarte sulcata.

Cardium echinatum. One in 42 only. ,, norvegicum.

Pinna pectinata. One in 42 only.

Lima Loseombii.

Pecten tigrinus.

", maximus.

, opercularis. Numerous.

Dentalium entalis.

Aporrhais pes-pelecani. One in 42 only.

\section{(B). PolyzoA.}

Cellaria sinuosa. ) Scarce. Most plentiful , fistulosa. $\}^{\text {in } 55 .}$

Scrupocellaria scruposa. $\left.\begin{array}{c}\text { Bugula avicularia. } \\ \text { flabellata. }\end{array}\right\}$ In 55 only.

Cellepora ramulosa. , On hydroids in 55 Pedicellina cernua. $\}$ only.

Incrusting polyzoa only moderately plentiful. For list see Table VI.

$$
\text { (B). Tunicata. }
$$

Polycarpa varians. Several specimens in a haul.

(B). Fishes.

Lepadogaster bimaculatus. Single specimens in a haul. 


\section{Ground XI. The North-West Eddystone Coarse Gravel.}

Hauls. 8 (Dr.), 9 (Dr.), 46 (Dr.), 47 (Dr.), 84 (Dr. and C.-dr.).

This ground lies just to the eastward of the Hand Deeps, and at a distance of two to three miles from the Eddystone. The dredgings were generally commenced on the line passing through the old and new Eddystone Lighthouses.

Bottom-deposit. Coarse gravel mixed with fine sand.

The texture, as indicated by percentage composition, is as follows, in the sample taken at haul $84:-$

\begin{tabular}{|c|c|c|c|c|}
\hline II. & Coarse Gravel & & .. & ... 47.6 per \\
\hline III. & Medium Gravel & $\ldots$ & $\ldots$ & $\ldots 14.5$ \\
\hline IV. & Fine Gravel & ... & $\ldots$ & ... $7 \cdot 5$ \\
\hline V. & Coarse Sand & $\ldots$ & $\ldots$ & $4 \cdot 0$ \\
\hline VI. & Medium Sand & $\ldots$ & $\ldots$ & $\ldots \quad 5 \cdot 9$ \\
\hline VII. & Fine Sand & $\cdots$ & $\ldots$ & $\ldots 17 \cdot 7$ \\
\hline VIII. & Silt $\quad \ldots$ & $\ldots$ & $\ldots$ & .. $2 \cdot 8$ \\
\hline
\end{tabular}

[84. Average grade of sample, 3.704. Percentage of carbonate of lime in whole sample, 34.66. Highest percentage occurs in IV., which contains 64.90 . In 84 VI. Foraminifera are not numerous. Twenty-one were counted in 0.45 grams (seven grains) of this grade, or 46 per gram. In 84 VII. Foraminifera are not numerous. In these grades the following foraminifera were found, arranged in order of frequency:-Truncatulina lobatula, Textularia gramen, Rotalia beccarii, Planorbulina mediterranensis, Discorbina rosacea, Miliolina bicornis, Bolivina dilatata, Miliolina seminulum, Bulimina pupoides, Lagena orbignyana, Nodosaria sp., Polymorphina lactea. In all, twelve species.-R. H. W.]

Shells are plentiful. For list see p. 422.

The principal difference of texture between this sample and that of Ground IX., which seems to be of importance, is the larger percentage of sand and silt in the present case, 18 per cent. and 3 per cent. respectively, as against 16 per cent. and 1 per cent. on Ground IX.

As will be seen by comparing the two faunas, the great difference between them is the presence or greater abundance on the present ground (XI.) of species typical of the fine sand grounds, which species are scarce or absent on Ground IX. Since the general nature of the fauna of the two grounds (IX. and XI.) is very similar, I shall assume in the following account of Ground XI. that the reader is acquainted with the nature of the fauna of Ground IX., which is the typical coarse gravel fauna, and shall confine myself to pointing out the differences between the two grounds. This method of treatment 
should bring out clearly the fact that fine sand species are more abundant on Ground XI. than on the typieal Gravel Ground IX.

Burrowing species. Ebalia tumefacta and Ebalia tuberosa are decidedly less numerous in XI. than in IX. Atelecyclus heterodon, of which small specimens are numerous in IX., is not abundant in XI. Cardium norvegicum, which was represented by one specimen in IX., was not taken in XI. Dentalium entalis, which was absent in IX., was present in one haul (47) in XI.

Fixed species. The only species common on the typical Coarse Gravel IX., which is scarce in XI., is Polycarpa varians, of which one or two specimens were taken in haul 47 only. On the other hand:-

Sertularella Gayi is much more common on XI. than it is on IX.

Antennularia antennina. Common on XI., is scarce on IX. " ramosa. " XI. " $\quad$ IX. IX.

Aglaophenia myriophyllum. Occasionally taken on XI., is absent on

Ascidiella scabra is more common on XI. than it is on IX.

Cellaria sinuosa

Cellaria fistulosa $\}$ are much more common on XI. than on IX.

Proneomenia aglaopheniae was found on XI., clinging to the stalk of Aglaophenia myriophyllum.

Wandering species. Pecten opercularis and Pecten maximus, which are common on the typical Gravel Ground IX., are scarce or absent on XI., and with them Asterias mubens and A. glacialis become scarce. The following species also, which are common on IX., are scarce or absent on XI. :-Ophiura albida, Eupagurus Bernhardus, Eupagurus Prideauxii, Anapagurus laevis, and Turritella communis.

\section{List of Species. Ground XI.}

\section{HydrozoA.}

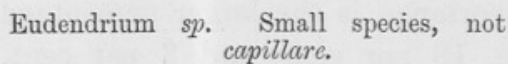
Bougainvillia ramosa. One piece in 84 only.

Clytia Johnstoni. Plentiful on hydroids and shells.

Lafoea dumosa. Creeping form only.

, fruticosa. Plentiful in 84 only.

Halecium halecinum. Plentiful, growing on Chaetopterus tubes and on shells, especially Pocten maximus shells.

, Beanii. Plentiful, growing on Chaetopterus tubes and on shells, especially Pecten maximus shells.
Sertularella Gayi. Plentiful, attached to polychaete tubes (especially Chaetopterus), or less frequently to shells. Not so common as Halecium.

Sertularella polyzonias. Less common than S. Gayi.

Antennularia antennina. Common, fixed in the sand by felt-work of fibres, or attached to Chactopterus tubes.

ramosa. Less common than A. antennina. Often fixed to Chaetopterus tubes.

Aglaophenia myriophyllum. Generally abundant, fixed in the sand by felt-work of fibres. 
Plumularia pinnata. On stems of Halecium or other hydroids.

, setacea. In 84 only, growing on stem of Antennularia antennina.

, Catharina. Plentiful, generally growing on Chaetopterus tubes.

\section{ActinozoA.}

Adamsia palliata. One specimen in 8 only, surrounding a Trochus gramulatus shell.

Paraphellia expansa. Three or four specimens covered with sand.

Caryophyllia Smithii. Attached to shells, often Pecten maximus shells.

Alcyonium digitatum. One or two small colonies only in each haul.

\section{Echinodermata.}

Astropecten irregularis. In 47 only.

Palmipes placenta. Two or three specimens in 8 and 9.

Solaster papposus. Small specimens (1 to 2 in. diam.) only.

Asterias glacialis. Not numerous.

", rubens. Generally not numerous, but several large ones in 84 .

Ophiura ciliaris. Abundant.

Ophiactis Balli. Generally present, hiding in crevices of shells, Chaetopterus tubes, \&c.

Ophiocoma nigra. Large specimens fairly plentiful in 47. Absent in other hauls.

Ophiothrix fragilis. Abundant.

Echinus acutus. One or two generally present.

,, miliaris. Numerous.

, esculentus. Not numerous.

\section{Nemertina.}

Eupolia curta. One specimen in 47 only.

\section{Polychaeta.}

Lepidonotus squamatus. Not numerous. Lagisca propinqua. One in 9 only.

Hyalinoecia tubicola. Several in each haul.

Nereis pelagica. Few in 8 only.

Chaetopterus variopedatus. Plentiful in all hauls.

Thelepus. Plentiful.

Terebellid tubes.

Sabella (pavonina?).

Sabellaria spinulosa. One in 8 only.

Hydroides pectinata.
Potamoceros triqueter.

Eurylepta cornuta.

Phascolion strombi.

Crustacea.

Eupagurus Bernhardus. One full-sized one in 84 and one small one in 9 .

, cuanensis. Not plentiful.

Anapagurus laevis. In 9 only.

Porcellana longicomis. Common.

Galathea dispersa. Common.

Stenorhynchus longirostris. Not plentiful.

Inachus dorsettensis. Not plentiful.

Eurynome aspera. One or two generally taken.

Portunus pusillus. Often numerous.

Atelecyclus heterodon. One in 47, one small one in 84 .

Ebalia tumefacta. Two or three generally " tuberosa. $\}$ present in each haul. , Cranchii.

Balanus crenatus. On Pecten opercularis. Scalpellum vulgare. On stem of Halecium and Antennularia.

Pyrgoma anglicum.

Phthisica marina.

Erichthonius abditus. Forming tubes on stem of Sertularella Gayi.

A Caprellid. On Antennularia. Mollusca. Living.

Saxicava rugosa, var. arctica. Numerous, attached to shells, roots of hydroids, \&c.

Venus fasciata. One specimen in 9 only. Kellia suborbicularis. Living in the mud inside empty bivalve molluse shells.

Modiola modiolus.

Lima Loseombii. In 46 only.

Pecten tigrinus. One in 47 only.

,, maximus. One or two generally taken.

" opereularis. Few adults. Small ones attached to hydroids numerous.

Anomia ephippium.

Dentalium entalis. In 47 only.

Pileopsis hungaricus. Attached to shells.

Emarginula reticulata. Common on shells. ,$\quad$ rosea. In 8 only.

Trochus granulatus. One in 9 only.

Eulima polita. One large specimen in 84 . Natica nitida. In 46 only.

Lamellaria perspicua. 
Buccinum undatum. Generally two or three specimens.

Proneomenia aglaopheniae. Occasionally found, on stem of Aglaophenia myriophyllum.

Scaphander lignarius.

Doto fragilis. On Halecium halecinum.

\section{Shells.}

Lyonsia norvegica. One or two only.

Solen ensis. One or two only.

Tellina donacina. Few only.

Tapes virginea. Numerous.

Artemis exoleta. Numerous.

Cardium echinatum. Few only.

$$
\text { , norvegicum. }
$$

Lima Loscombii. Many in 46 only.

Pecten maximus. Fairly numerous.

, opercularis. Abundant. (Few in

Dentalium entalis.
Trochus granulatus. One in 8 , with Adamsia palliata.

Turritella communis. Few.

\section{Polyzoa.}

Cellaria sinuosa. $\}$ fistulosa. Not in large quantity. " ficellaria ciliata. Fixed to hydroids, \&c.

Scrupocellaria scruposa. Fixed to the base of hydroids and to shells. Plentiful.

$\left.\begin{array}{c}\text { Cellepora avicularis. } \\ \text { " ramulosa. }\end{array}\right\} \begin{array}{r}\text { Attached to hy- } \\ \text { droids. }\end{array}$

Idmonea serpens.

Incrusting species not very numerous. For list see Table VI., p. 534.

TUNicata.

Molgula oculata. In 47 only. ,, sp. In 46.

Polycarpa varians. One or two large in 47 only.

Ascidiella venosa. Few.

, scabra. Few only.

Edge of Hand Deeps.

Ground XII.

Haul 83 (Dr. and C-dr.).

Bottom-deposit. Medium gravel mixed with some mud. Texture :-

II. Coarse Gravel $\quad \ldots \quad \ldots \quad \ldots 27 \cdot 9$ per cent.

III. Medium Gravel $\ldots . \quad \ldots \quad \ldots 28 \cdot 3 \quad$ ”

IV. Fine Gravel $\quad \ldots \quad \ldots \quad \ldots 14 \cdot 1$,

$\begin{array}{lllllll}\text { V. Coarse Sand } & \ldots & \ldots & \ldots & 6.0 & \end{array}$

VI. Medium Sand $\quad \ldots \quad \ldots \quad \ldots \quad \ldots \quad 7 \cdot 3 \quad$,

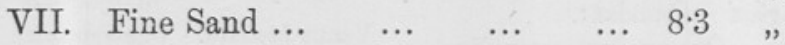

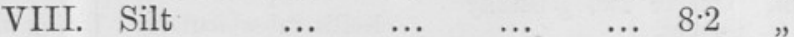

[83. Average grade of sample, 3.946. Percentage of carbonate of lime in whole sample, $40 \cdot 74$. Highest percentage occurs in V., which contains $62 \cdot 29$. In II. over 90 per cent. by weight of the rock constituents are Triassic, and only about 8 per cent. derived from the Eddystone reef. In III. over 70 per cent. by weight of the rock constituents are Triassic, over 18 per cent. derived from the Eddystone reef, and about 10 per cent. are Devonian. In 83 VI. Foraminifera are particularly abundant, as also in $83 \mathrm{VII}$. In these grades the following species occur, arranged in order of frequency:-Truncatulina lobatula, Miliolina seminulum, Spiroloculina planulata, Rotalia beccarii, Discorbina rosacea, Textularia gramen, Textularia agglutinans, Miliolina bicornis, Lagena orbignyana, Planorbulina mediterranensis, Bolivina dilatata, Spirillina vivipara, Biloculina ringens, Bulimina pupoides. In all, fourteen species.- $\mathrm{R}$. H. W.] 
Shells are plentiful.

The fauna of this haul was comparatively poor both in number of species and in number of specimens. It will be seen that the species taken consist in about equal numbers of those typical of the fine sand, as found on Grounds I. and III., and of those typical of the coarse gravel, as found on Ground IX. haul.

Burrowing species. There was no burrowing species recorded in the

Fixed species. Of species fixing by masses of root-fibres to the bottom-deposit, Antennularia antennina was abundant, and Antennularia ramosa and Aglaophenia myriophyllum, the latter bearing Proneomenia aglaopheniae, were present in smaller quantity. Cellaria was represented only by one fragment of $C$. fistulosa. There was a moderate number only of Chaetopterus variopedatus and a small quantity of Halecium halecinum. Sertularella Gayi was plentiful fixed as on the fine sand grounds to the tubes of Thelepus (cincinatus?). A few other hydroids were present, as will be seen from the list. One specimen of Ascidiella scabra was found, attached to the base of Antennularia antennina. There were few incrusting Polyzoa. One specimen of Lepadogaster bimaculatus was taken.

Wandering species. Ophiura ciliaris and Ophiothrix fragilis were both numerous, but only one specimen of Asterias glacialis and of Echinus esculentus was taken. Single specimens of Eupagurus Bernhardus, Eurynome aspera, Pecten maximus, and Buccinum undatum were found, and a few half-grown Pecten opercularis.

\section{List of Species. Ground XII.}

\section{HydROZOA.}

Eudendrium ramosum. Fairly plentiful. , sp. Small species, not $E$. capillare.

Bougainvillia ramosa. Small variety in quantity.

Campanularia Hincksii. On Cellaria fistulosa.

Halecium halecinum. Small quantity only.

Sertularella Gayi. Plentiful.

,, polyzonias. Moderatequantity. Antennularia antennina. Plentiful.

", ramosa. One or two pieces only.

Aglaophenia myriophyllum. One or two pieces only.

Plumularia pinnata. Small quantity.

[Antennularia antennina and ramosa were much more plentiful in this haul than in 84 on Ground XI. In 84 Halecium halecinum was much more common.]
Echinodermata.

Asterias glacialis. One large specimen.

Ophiura ciliaris. Eight or ten specimens. Ophiactis Balli. One in an empty Chaetopterus tube.

Ophiocoma nigra. One small one only. Ophiothrix fragilis. Very many.

Echinus esculentus. One.

\section{Polychaeta.}

Chaetopterus variopedatus. Few only.

Pectinaria auricoma. One only.

Thelepus.

Dasychone bombyx. Several.

\section{Crustacea.}

Eupagurus Bernhardus. One in Buccinum undatum shell.

Eurynome aspera. One.

Scalpellum vulgare. On Halecium halecinum. 
Erichthonius abditus, Forming tubes on Sertularella Gayi.

Mollusoa. Living.

Modiola modiolus. Small specimens only.

Pecten maximus. One only.

", opercularis. A few half-grown ones.

Anomia ephippium. Small, abundant on Chatopterus tubes.

Buccinum undatum. One.

Proneomenia aglaopheniae. On Aglao phenia myriophyllum.

Doto fragilis. On Halecium halecinum.

$$
\text { Shells. }
$$

Lutraria elliptica.

Cyprina islandica.

Cardium echinatum.

" norvegicum. Small shells only.

Pecten maximus. One.
Pecten opercularis. Many.

Buccinum undatum. With Eupagurus Bernhardus.

\author{
PolyzoA.
}

Cellaria fistulosa. One small piece only.

Idmonea serpens.

Cellepora avicularis.

Few incrusting Polyzoa. Shells mostly clean.

On $P$. opercularis shells :-

Schizoporella linearis.

Porella concinna.

Schizoporella auriculata.

Rhynchopora bispinosa.

Tunicata.

Ascidiella scabra. One at root of Antennularia antennina.

Piscess.

Lepadogaster bimaculatus. One.

\section{Ground XIII.}

One mile south-east of the Eddystone.

Haul 103 (Dr.).

Bottom-deposit. The bottom-deposit consists of a mixture of shellgravel of medium texture, with a considerable quantity of mud. This is shown by the following figures expressing the composition of the sample :-

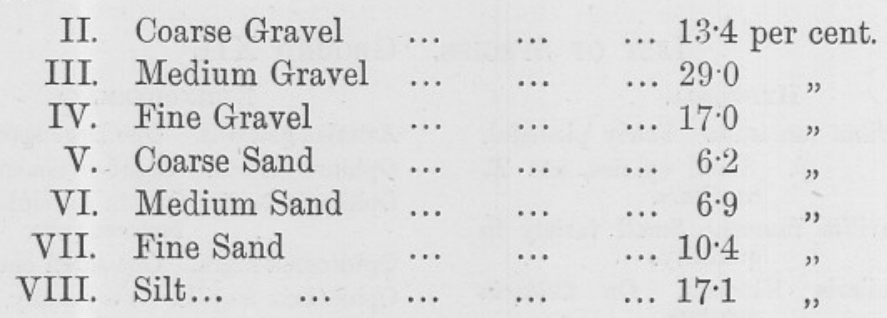

[103. Average grade of sample, 4.638. Percentage of carbonate of lime in whole sample, $61 \cdot 18$. Highest percentage occurs in III., which contains 90.50 per cent. This grade, which constitutes 29 per cent. of the whole sample, is the predominant grade in the sample. The rock constituents in 103 II. are proportioned as follows:-Trias, 79 per cent.; Eddystone reef, 17 per cent.; Devonian, 4 per cent.; while 103 III. contains little or no Devonian, but Trias and Eddystone reef materials in the proportion of 74 per cent. and 26 per cent. 0.13 grams (two grains) of 103 VII. contained 203 foraminifera, or 1562 per gram, a large number as compared with nearly every other sample, 
except perhaps 89B. The following species of foraminifera occur in 103 VI. and VII., arranged in order of frequency :-Truncatulina lobatula, Rotalia beccarii, Textularia gramen, Miliolina seminulum, Bulimina pupoides, Discorbina rosacea, Lagena orbignyana, Bolivina dilatata, Polymorphina lactea, Miliolina trigonula, Textularia agglutinans, Spirillina vivipara, Globigerina bulloides. In all, fourteen species-the largest number of distinct species found in any of the samples.R. H. W.]

Shells are numerous. For list see p. 426.

It is possible that the accumulation of silt at this place may be due to its being somewhat sheltered from the south-westerly swells by the Eddystone reef, which runs out in a southerly direction. Rocky ground was found due south of the lighthouse, at a distance of one mile (hauls 31 and 78. See Chart I.).

Fauna. The fauna has many points in common with that of the gravel and fine sand grounds to the west of the Eddystone (e.g., Ground IX.). Chaetopterus, for instance, is very plentiful and with it Halecium halecinum and Plumularia Catharina. Ophiothrix fragilis is also very abundant, and the Echinoderm and Crustacean faunas are similar to those of Ground IX. There are, however, some marked points of difference between the two grounds. Pecten opercularis, which was plentiful on Ground IX., is scarce on XIII., and with it Asterias rubens and $A$. glacialis are scarce. Many full-sized specimens of Atelecyclus heterodon were taken on Ground XIII., which may be regarded as a centre of distribution for this species, whilst on Ground IX. the specimens, though numerous, were all small.* On the other hand, Turritella communis, of which living specimens were numerous on IX, was not taken on XIII., and Polycarpa varians, the abundance of which was one of the features of IX., was represented by a few small specimens only in XIII. Hyalinoecia tubicola, as on Ground IX., was plentiful.

Species typical of the fine sand grounds were absent or represented only by stray specimens.

The presence of several fair-sized pieces of Alcyonium digitatum, of which only very small colonies were taken growing on $P$. opercularis on Ground IX., is noteworthy, and, like the large quantity of silt in the bottom-deposit, may be due to the more sheltered position of the ground. (Cf. p. 376.) The masses of Filograna implexa also were much larger here than on any other ground examined.

* Haul 93 (Ground IX.) was made on March 3rd, 1898, and haul 103 (Ground XIII.) on May 26th, 1898. The difference in size between the specimens on the two grounds was probably greater than would be accounted for by growth between the two dates, though in the absence of direct evidence the point is somewhat uncertain. 


\section{List of Species. Ground XIII.}

\section{HyDrozoA.}

Lafoea dumosa, var. robusta. Plentiful. Halecium halecinum. Plentiful.

Sertularella Gayi. Scarce.

Hydrallmania falcata. A little.

Antennularia antennina.

Aglaophenia myriophyllum.

Plumularia pinnata.

$$
\text { , Catharina. }
$$

ActinozoA.

Caryophyllia Smithii. On shells.

Alcyonium digitatum. Several pieces.

Sarcodictyon catenata. A little on shells.

Adamsia palliata. Few only, with Eupagurus Prideauxii.

\section{ECHINODERMATA.}

Thyone fusus. One large specimen.

Solaster papposus. One.

Asterias rubens. One.

Ophiura ciliaris. One.

," albida. Several.

Ophiactis Balli. Plentiful in crevices amongst Chaetopterus tubes.

Ophiothrix fragilis. Many.

Echinus miliaris.

, esculentus. One only.

Echinocyamus pusillus.

Amphiporus pulcher.

\section{Nemertina}

Micrura purpurea.

, fasciolata.

\section{Polychaeta}

Lepidonotus squamatus. Two specimens. Lagisca propinqua. Five specimens.

Hyalinoecia tubicola. Several.

Lumbriconereis, small. One only.

Chaetopterus variopedatus. Very numerous.

Polymnia nebulosa. One large specimen.

Polycirrus aurantiacus. Two specimens.

Filograna implexa. Considerable quantity.

Dasychone bombyx. Three large specimens.

Serpula vermicularis.

Hydroides pectinata.

\section{Crustacea.}

Eupagurus Prideauxii. Few only. , cuanensis. In Aporrhais pespelecani shell.

Porcellana longicornis,
Galathea dispersa. Plentiful.

Stenorhynchus longirostris.

Inachus dorsettensis. Dressed with sponges, Compound Ascidians, Anomia, and small Serpulids.

Eurynome aspera. Few only.

Portunus depurator.

Atelecyclus heterodon. Numerous.

Ebalia tuberosa.

\section{Mollusca, Living.}

Saxicava rugosa, var. arctica.

Astarte suleata. One living.

Nucula nucleus. One living.

Pecten tigrinus. One living.

Pecten maximus.

, opercularis. A few only.

Anomia ephippium. Large specimens. ,, patelliformis.

Trochus granulatus. One living.

Eulima polita. One large living specimen.

Buccinum undatum. One small one.

Cypraea europaea.

Doto fragilis. On Halecium halecinum.

$$
\text { Shells. }
$$

Lyonsia norvegica. One.

Tapes virginea.

Venus ovata.

Cardium echinatum.

$$
\text { ", norvegicum. }
$$

Nucula nucleus.

Pectunculus glycimeris. One small shell.

Pecten maximus. Numerous. , opercularis.

Aporrhais pes-pelecani. Shell inhabited by Eupagurus cuanensis. PolyzoA.

$\left.\begin{array}{c}\text { Cellaria sinuosa. } \\ \text {, fistulosa. }\end{array}\right\}$ A little only.

Scrupocellaria scruposa,

Many incrusting forms on shells.

\section{Tunicata.}

Ascidiella scabra. Few only.

Polycarpa varians. A few small.

Styelopsis grossularia. Squat variety plentiful on Pecten shells.

Compound ascidian on Sertularella Gayi.

Pisces.

Lepadogaster bimaculatus. One. 
Ground XIV. The West Eddystone Fine Gravel.

Hauls. 73 (O.-tr.), 74 (Dr.), 35 (Dr.), 36 (O.-tr.), 88 (Dr.), 41 (Dr.), 85 (C.-dr. and Dr.), 58 (Dr.), 59 (Dr.).

Bottom-deposit. Fine gravel. A sample with the canvas dredge was taken only at haul 85, and had the following texture :-

$\begin{array}{rllllll}\text { II. } & \text { Coarse Gravel } & \ldots & \ldots & \ldots & 4 \cdot 1 & \text { per cent. } \\ \text { III. } & \text { Medium Gravel } & \ldots & \ldots & \ldots & 17 \cdot 5 & , \\ \text { IV. } & \text { Fine Gravel } & \ldots & \ldots & \ldots & 28 \cdot 1 & , \\ \text { V. } & \text { Coarse Sand } & \ldots & \ldots & \ldots & 21 \cdot 0 & , \\ \text { VI. } & \text { Medium Sand } & \ldots & \ldots & \ldots & 23 \cdot 4 & , \\ \text { VII. } & \text { Fine Sand ... } & \ldots & \ldots & \ldots & 5 \cdot 2 & , \\ \text { VIII. } & \text { Silt } \quad \ldots & \ldots & \ldots & \ldots & 0 \cdot 6 & \end{array}$

[85. Average grade of sample, 4.597. Percentage of carbonate of lime in whole sample, 27.87. Highest percentage occurs in II., which contains 56.00 per cent., but this grade is only present in small proportion, and III. at 39.50 per cent. is more reliable. Practically speaking in grades II. and III. 66 per cent. by weight of the rock fragments are Triassic, 28 per cent. derived from the Eddystone reef, and 6 per cent. apparently Devonian. A great feature in this sample is the evidence of long-continued and somewhat violent wave action, presented by the beautifully rounded and polished form of the quartz grains and other constituents of the gravels and sands, especially in the finer grades. This will be found referred to at greater length elsewhere (pp. 376 and 385). Foraminifera are not numerous, the smaller varieties are absent, and Milioline forms largely predominate. The following species were found in VI. and VII., and have been arranged in order of frequency :Miliolina seminulum, Rotalia beccarii, Textularia gramen, Textularia agglutinans, Miliolina bicornis, Discorbina rosacea, Biloculina ringens. In all, seven species.-R. H. W.]

Shells were numerous (for list see p. 430). The material of the gravel in the above sample was largely inorganic, but in some of the other hauls, where no samples were taken with the canvas dredge, there were indications of the deposit containing a much larger quantity of broken shell, more nearly approaching that of Ground XVI. (Haul 87.)

Burrowing species. The most characteristic burrowing animals on this ground are Spatangus purpureus, Cardium norvegicum, and Drepanophorus rubrostriatus.

Fixed species. Very few hydroids are present, the most common forms being Halecium halecinum and Halecium Beanii fixed to the tubes of Chaetopterus, which is moderately plentiful, but not nearly so 
numerous as on the typical coarse gravel and sand of Ground IX. The scarcity of hydroids may be due to the disturbance of the deposit by periodic wave action, the existence of which, as pointed out above, is also shown by the rounded and polished quartz grains. One of the characteristic features of the fauna is the presence of large specimens of Polycarpa varians attached to the gravel. Caryophyllia Smithii is plentiful on shells and Sarcodictyon catenata is also not uncommon. There are few branched polyzoa, but incrusting forms on shells are numerous.

Wandering species. The presence of Porania pulvillus in considerable numbers, and of Luidia Sarsi in small numbers, must be regarded as characteristic. Ophiothrix fragilis is plentiful, but Ophiura ciliaris, though generally present, is never numerous. Echinus esculentus and E. acutus are not uncommon. Pecten opercularis was very numerous in some hauls, but scarce in others, the abundance of A. glacialis and $A$. rubens varying with that of the mollusc. Two or three specimens of Pecten maximus were present in each haul, and must be considered as one of the characteristic features of the ground. Crustaceans were not numerous; the species represented were those typical both of the fine sand and of the coarse gravel.

Considering the fauna of this ground as a whole, one may regard it as composed of four elements, viz. (1), a fauna of its own, represented by an abundance of Polycarpa varians, Porania pulvillus, Pecten opercularis, Cardium norvegicum, Echinus esculentus, and E. acutus; (2) many species found on the coarse gravel grounds, e.g., Ophiothrix fragilis (abundant), Chaetopterus variopedatus and its associates, Ebalia tumefacta and tuberosa; (3) species characteristic of the clean shell gravel of the neighbouring Ground XVI., e.g., Spatangus purpureus, Sarcodictyon catenata; (4) a few immigrants from the fine sand grounds, e.g., Sertularella Gayi (scarce), Astropecten irregularis (an occasional small specimen only), Ophiura ciliaris, and Ascidiella scabra.

\section{List of Species. Ground XIV.} Porifera.

Suberites domuncula.

Cliona celata. Common, boring shells.

HydrozoA.

Hydractinia echinata. In 73 only.

Clytia Johnstoni. On hydroids in 73 .

Campanularia Hincksii. On hydroids and on shells.

Lafoea dumosa, var. robusta. Recorded in 58 only.

Halecium halecinum. Fairly abundant on Chactopterus tubes and on shells.
Halecium Beanii. Small quantity in 59 only.

, labrosum. One colony in 73 .

Sertularella Gayi. Small quantity only.

$$
\begin{array}{r}
\begin{array}{r}
\text { polyzonias. Small quantity } \\
\text { only. }
\end{array} \\
\text {, }
\end{array}
$$

Sertularia argentea. A little in 35 only.

Hydrallmania falcata. A few colonies only.

Antennularia antennina. A few colonies only.

" ramosa. A few colonies only. 
Plumularia pinnata. In 35 only. , Catharina. Green variety in 58 only.

\section{ActinozoA.}

Adamsia palliata. On shell inhabited by Eupagurus Prideauxii in 73 only.

Caryophyllia Smithii. Plentiful on shells. Alcyonium digitatum. A few small colonies only, chiefly on Pecten opercularis.

Sarcodictyon catenata. Good colonies on shells in 41 and 58 , in latter case on Lutraria elliptica shell.

\section{Echinodermata.}

Astropecten irregularis. One or two specimens, generally small, in a haul. One or two large specimens in 58.

Luidia Sarsi. One specimen in each of the hauls 73 and 36 (Otter-trawl).

Porania pulvillus. Plentiful in 73 and 36 .

Solaster papposus. Few specimens, generally small.

Henricia sanguinolenta. One specimen in 36 and in 88 .

Asterias glacialis. Generally plentiful. Some very large specimens.

,, rubens. Comparatively few. Much less numerous than A. glacialis.

Ophiura ciliaris. One or two specimens in each haul.

,, albida. Not numerous.

Ophiactis Balli. Fairly numerous amongst Chaetopterus tubes, \&c.

Ophiocoma nigra. Few or none.

Ophiothrix fragilis. Numerous.

Echinus acutus. Present in 36, 73, and 74 .

", miliaris. Generally present.

", esculentus. Present in 73, 36, and 41 ; abundant in 36 only.

Echinocyamus pusillus. In 74 .

Spatangus purpureus. A few generally taken, except in 73 and 36 , which were hauls of the Otter-trawl.

Carinella superba.

\section{Nemertina.}

Drepanophorus rubrostriatus. In 73,58 , and 85 .

Tetrastemma flavidum.

$$
\text { ,, candidum. }
$$

Lineus bilineatus.

$$
\text { NEW SERIES. - VOL. V. NO. } 4 .
$$

Micrura purpurea.

, fasciolata.

Polychaeta.

Lepidonotus squamatus. Few only.

Evarne impar. One in 41 only.

Eunice Harassi. One in 88 only.

Lumbriconereis. Large species.

$$
\text { ,, Small , }
$$

Chaetopterus variopedatus. Numerous, attached to shells.

Polymnia nebulosa. One in 88 .

Thelepus. One only recorded.

Terebellid tubes. Very plentiful.

Filograna implexa. Common on Pecten opercularis shells.

Protula tubularia. Few only.

Serpula vermicularis. Fairly plentiful.

Hydroides pectinata. Fairly plentiful,

Phascolion strombi.

\section{Crustacea.}

Eupagurus Bernhardus. A few only in Buccinum undatum shells.

, $\quad$ Prideauxii. In 73 only, with Adamsia palliata.

,, cuanensis. One in 85 only.

Porcellana longicornis.

Galathea dispersa.

Stenorhynchus longirostris. Not numerous.

Inachus dorsettensis. Not numerous.

Eurynome aspera. In 73 only.

Portunus depurator. In 36 and 88 only.

Ebalia tumefacta. In 88 only. One or two specimens.

, tuberosa. One or two specimens in 35 and 85 only.

Balanus crenatus.

Scalpellum vulgare. On stem of hydroids.

\section{Mollusca. Living.}

Tapes virginea. One each in 88 and 41 only.

Astarte sulcata. One or two specimens in 73 only.

Cardium norvegicum. In 58, 85, and 88 .

Montacuta substriata. On spines of Spatangus purpureus.

Kellia suborbicularis. In 88 only.

Modiola modiolus.

,, barbata.

Lima Loscombii. In 35 and 41 only.

Pecten maximus. A few specimens generally present.

,, opercularis. Many in 73 and 36 . Few in other hauls. 
Anomia ephippium. Generally on Pec,, patelliformis. $\}$ ten opercularis.

Chiton asellus. Frequent on shells.

Pileopsis hungaricus.

Emarginula reticulata.

Trochus zizyphinus. In 35 only. Small variety.

Buccinum undatum. Few or none.

Cypraea europaea. In 73 only.

Tritonia plebeia.

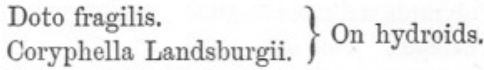

Solen ensis. Few.

$$
\text { Shells. }
$$

Psammobia ferroensis. One small one in 74.

Lutraria elliptica. Common.

Tapes virginea. Very common.

Venus striatula.

, fasciata.

Artemis exoleta.

Cyprina islandica.

Astarte sulcata.

Cardium echinatum. Few only. , norvegicum. Abundant.

Nucula nucleus.

Pectunculus glycimeris.
Pinna pectinata. One in 73 only.

Lima Loscombii. Frequent.

Pecten tigrinus. Not numerous. , maximus. Abundant. ,, opercularis. Abundant.

Dentalium entalis. Not abundant. Turritella communis. Not abundant. Scalaria Turtonis. One in 73 only. Buccinum undatum. In 73 only.

PolyzoA.

Cellaria fistulosa. Very little.

Scrupocellaria scruposa. In 85 only at roots of Antennularia.

Bugula avicularia. One piece in 85 .

Cellepora avicularis.
Crisea eburnea. On hydroid stems.

Crisea eburnea. see Table VI., p. 534.

\section{Tunicata.}

Styelopsis grossularia. Small flat variety common on shells, especially Pecten maximus shells.

Polycarpa varians. Abundant.

Ascidiella scabra. Not numerous.

Ciona intestinalis. In 73 only.

\section{Ground XV. East Eddystone Fine Gravel.}

Hauls. 33 (Dr.) and 97 (Dr. and C.-dr.).

Two hauls lying from one to two miles east and south-east of the Eddystone have a similar fauna, and have been united as Ground XV.

Bottom-deposit. Fine gravel.

The texture of a sample taken at 97 is as follows:-

$\begin{array}{rllllll}\text { II. } & \text { Coarse Gravel } & \ldots & \ldots & \ldots & 13.4 & \text { per cent. } \\ \text { III. } & \text { Medium Gravel } & \ldots & \ldots & \ldots & 20.5 & \\ \text { IV. } & \text { Fine Gravel } & \ldots & \ldots & \ldots & 18 \cdot 2 & , \\ \text { V. } & \text { Coarse Sand } & \ldots & \ldots & \ldots & 16.0 & " \\ \text { VI. } & \text { Medium Sand } & \ldots & \ldots & \ldots & 19 \cdot 7 & , \\ \text { VII. } & \text { Fine Sand ... } & \ldots & \ldots & \ldots & 9 \cdot 0 & , \\ \text { VIII. } & \text { Silt } \quad \ldots & \ldots & \ldots & \ldots & 3.1 & ,\end{array}$

[97. Average grade of sample, $4 \cdot 471$. Percentage of carbonate of lime in whole sample, $46 \cdot 68$. Highest percentage in V., which contains $77 \cdot 70$ per cent. In 97 II. the gravel consists of Trias, 91 per cent.; Eddystone reef, 7 per cent.; Devonian, 2 per cent. In 97 III. the proportions are Trias, 75 per cent.; Eddystone reef, 17 per cent.; Devonian, 8 per cent. Sixty foraminifera were counted in 0.13 grams 
( 2 grains) by weight, of 97 VII. 461 per gram. The following list of species of foraminifera in $97 \mathrm{VI}$. and VII. is arranged as before:Miliolina seminulum, Rotalia beccarii, Textularia gramen, Truncatulina lobatula, Discorbina rosacea, Miliolina trigonula, Lagena sulcata, Biloculina depressa, Miliolina bicornis, Lagena orbignyana, Spirillina vivipara, Bulimina pupoides. In all, twelve species.-R. H. W.]

Unbroken shells were not numerous.

Fauna. As will be seen from the list, the ground is very barren. The fauna shows no distinct characteristic species of its own, and seems to be made up of stray individuals from the various grounds in the neighbourhood, the sand, the gravel, and the broken shell faunas being represented.

\section{List of Species. Ground XV.}

\section{Porifera.}

Cliona celata. Boring shells.

\section{HYDROZOA.}

Eudendrium, sp. Small species with male and female gonophores on Halecium Beanii in 33 .

Clytia Johnstoni. In 97 .

Lafoea dumosa, var. robusta. In 97 .

Trichydra pudica. In 97 on Halecium and on Pecten shell.

Halecium halecinum. A little in both. , Beanii. A little in both.

Sertularella Gayi. A small quantity in each.

Hydrallmania faleata. In 97 only.

$\left.\begin{array}{c}\text { Antennularia antennina. } \\ \text { ramosa. }\end{array}\right\}$ A little only. ramosa. $\}$ A little only.

Aglaophenia myriophyllum. In 33 only.

Plumularia Catharina. Growing in Halecium.

ActinozoA.

Caryophyllia Smithii. Several specimens on shells in 97 .

Alcyonium digitatum. Very small colony on stem of Halecium Beanii in 33.

Sarcodictyon catenata. In 97 only, on shells.

EOHINODERMata.

Astropecten irregularis. One in 97 only. Echinocardium cordatum. One in 97 only.

\section{Polychaeta.}

Chaetopterus variopedatus. One small piece of tube in 97 .

Terebellid tubes.
Hydroides pectinata.

\section{Crustacea,}

Galathea dispersa.

Stenorhynchus longirostris. In 33 only.

Inachus dorsettensis. In 33 only.

Atelecyclus heterodon. One in 97 only.

Scalpellum vulgare. At base of hydroids.

A caprellid on Antennularia antennina.

Mollusda. Living.

Pectunculus glycimeris. A few small.

Pecten opercularis. Small ones only.

Anomia patelliformis. On Pecten maximus

Chiton asellus. shells.

Shells.

Tapes virginea.

Pectunculus glycimeris. Small only.

Lima Loscombii.

Pecten maximus.

,, opercularis.

\section{PolyzoA.}

Shells mostly clean,

On P. maximus shell:Lichenopora hispida.

Mucronella ventricosa.

On Terebellid tube:-

Cellepora avicularis.

Tunicata.

Forbesella tesselata. In 97 .

Cephalochorda.

Amphioxus lanceolatus. In 97 . 
Ground XVI. The West Eddystone Clean Shell Gravel.

Hauls. 86 (Dr.), 87 (Dr. and C.-dr.), 10 (Dr.), 13 (Dr.), 14 (Dr.), 98 (Dr.), and 99 (Dr.).

Immediately bordering the rocky ground of the reef, north, west, and south of the Eddystone, at a distance of from half to one mile from the lighthouse, is a strip of clean shell gravel upon which the fauna is very scanty, though at the same time very characteristic.

Bottom-deposit. Clean shell gravel.

A sample taken at haul 87 had the following texture :-

$\begin{array}{rllllll}\text { II. } & \text { Coarse Gravel } & \ldots & \ldots & \ldots & 17 \cdot 3 & \text { per cent. } \\ \text { III. } & \text { Medium Gravel } & \ldots & \ldots & \ldots & 31 \cdot 7 & , \\ \text { IV. } & \text { Fine Gravel } & \ldots & \ldots & \ldots & 19 \cdot 3 & , \\ \text { V. } & \text { Coarse Sand } & \ldots & \ldots & \ldots & 10 \cdot 5 & , \\ \text { VI. } & \text { Medium Sand } & \ldots & \ldots & \ldots & 14 \cdot 9 & , \\ \text { VII. } & \text { Fine Sand ... } & \ldots & \ldots & \ldots & 5 \cdot 2 & , \\ \text { VIII. } & \text { Silt } \quad \ldots & \ldots & \ldots & \ldots & 1 \cdot 1 & \end{array}$

[87. Average grade of sample, 4.151. Percentage of carbonate of lime in whole sample, $72 \cdot 25$. Highest percentage occurs in IV., which contains 79.60 per cent. This deposit lying on the northern boundary of the Eddystone reef, just below the 30 -fathom line, is the one and only sample in which Eddystone reef materials predominate over the other rock constituents. In grade II. no rock fragments but those derived from the reef are present, while in grade III. Eddystone material stands at 74 per cent. and Trias at 26 per cent. Foraminifera are numerous; in VII. 81 individuals were counted in 0.13 grams (2 grains), or 623 per gram. The Miliolina greatly predominate. The following species were found in VI. and VII., arranged as before in order of frequency:-Miliolina seminulum, Rotalia beccarii, Textularia gramen, Truncatulina lobatula, Miliolina bicornis, Miliolina trigonula, Spiroloculina planulata, Lagena orbignyana, Spirillina vivipara, Discorbina rosacea. In all, ten species.-R. H. W.]

Large unbroken shells were not numerous.

Haul 99 was partly on rocky ground.

Burrowing species. The most characteristic species are Spatangus purpureus, Echinocyamus pusillus, Eupolia curta, Amphioxus lanceolatus, and Glycera convoluta. Several bivalve molluscs not taken on other grounds were found here (see p. 433). Occasional specimens of Polygordius were obtained, and Terebellid tubes were numerous.

Fixed species. These were very scarce. Lafoea dumosa, var. robusta, was the hydroid most frequently taken, other species being represented by occasional small pieces only. Sarcodictyon catenata attached to 
shells was common, and one of the characteristic species of the ground. Molgula oculata occurs fixed in the gravel. Polyzoa were not numerous.

Wandering species. The only species taken in numbers were Echinus miliaris, Amphiura elegans (peculiar to this ground), and Porcellana longicornis. Occasional specimens of the following species not commonly distributed on the other grounds around the Eddystone are noteworthy:-Plumularia frutescens, Cucumaria lactea, Holothuria nigra, Lima Loscombii, Aporrhais pes-pelecani (living), and Aegirus punctilucens.

\section{List of Species. Ground XVI.}

\section{HydrozoA.}

Lafoea dumosa, var. robusta. Frequent, but in small pieces.

Halecium halecinum. Little or none.

Sertularella Gayi. Little or none.

Diphasia rosacea. $\quad$ tamarisca. $\}$ In 99 only.

Sertularia argentea. Growing on Diphasia tamarisca.

Hydrallmania falcata. A little in 99 only. Antennularia ramosa. Little or none. Aglaophenia tubulifera. In 99 only. Plumularia Catharina. In 99 only. ,, frutescens. A large colony on Pecten opercularis shell in 10 only.

\section{ActinozoA.}

Caryophyllia Smithii. Many in 10. Few or none in other hauls.

Alcyonium digitatum. Several pieces in 99 broken from rock. None in other hauls.

Sarcodictyon catenata. Frequent.

Echinodermata.

Cucumaria lactea. Two specimens in 99 only.

Holothuria nigra. In 10 and 99. Two or three specimens.

Astropecten irregularis. One in 87 only.

Solaster papposus. Small. In 10 only.

Amphiura elegans. Numerous in 10 and 14.

Ophiactis Balli. Occasional specimens only.

Ophiocoma nigra. Small. In 10 only.

Ophiothrix fragilis. Small. In 10 only.

Echinus miliaris. Plentiful.

, esculentus. Three specimens in 99 only.

Echinocyamus pusillus. Generally present. Spatangus purpureus. One or two in each haul.
Nemertina.

Carinella annulata.

Tetrastemma candidum.

Eupolia curta.

Micrura purpurea. , fasciolata.

Cerebratulus fuscus.

\section{Polychaeta.}

Polygordius, sp. Occasional specimens.

Harmothoë imbricata. One in 87.

Lumbriconereis. Large. One in 98.

Ehlersia cornuta. One in 87.

Glycera convoluta.

Terebellid tubes. Numerous.

Dasychone bombyx. One in 87 .

Protula tubularia. Occasional specimens.

Hydroides pectinata. Occasional specimens.

\section{Crustacea.}

Eupagurus cuanensis. Infested with Sacculina. In Dentalium shell. One in 10 only.

Porcellana longicornis.

Galathea dispersa. In 13 only.

Portunus pusillus. In 10 only.

Ebalia tumefacta. In 10 and 13.

Balanus crenatus. On Pecten opercularis. Pyrgoma anglicum. With Caryophyllia Smithii.

Mollusca. Living.

Psammobia costulata, Turton. One living specimen in 10.

Tellina crassa. In 87 and 99 only.

Tapes virginea. One in 87 only.

Venus fasciata. In 13 only.

Artemis exoleta. Two living specimens in 99 only.

Cardium norvegicum. In 87 only. 
Montacuta substriata. On Spatangus purpureus.

Lima Loscombii. Fairly plentiful in 10.

Pecten tigrinus. In 13 only.

, maximus. One or two in 13 and 14 .

, opercularis. Few, mostly small specimens.

Chiton asellus. In 13 only.

Emarginula reticulata. Few.

A porrhais pes-pelecani. In 87 only.

Aegirus punctilucens. One specimen in 10 only. This was very pale in colour, and no green specks were to be seen. Small specimen.

Tellina crassa. Shells.

Lutraria elliptica.

Tapes virginea. Numerous.

Artemis exoleta. Numerous, especially

Astarte sulcata.

Cardium norvegicum. Numerous.
Pectunculus glycimeris. Small only.

Lima Loscombii.

Pecten maximus.

, opercularis.

Dentalium entalis.

Aporrhais pes-pelecani.

PolyzoA.

Cellepora ramulosa. In 99 only.

Crisea ramosa. In 13 only.

Idmonea serpens. In 13 only.

Incrusting polyzoa not very numerous, though a good many species are represented. For list see Table VI., p. 534.

Tunicata.

Ascidiella scabra, A few in 87 only.

Molgula oculata. A few only.

Botryllus, sp.

Cerphalochorda.

Amphioxus lanceolatus. A small specimen in 87 .

Ground XVII. The Bolt Head Shell Gravel.

Hauls 1, 6, 7, 21, 43, 44, 61, 62, 68, 105, 106, 107. 27, 28. 20, 60 (all hauls of Dredge. Canvas-dredge at 105 and 106).

The position of this ground, which lies south of Bolt Head, will be seen from the charts. The hauls enumerated above have been combined as one ground, though further investigation would probably lead to a division into at least three. This is indicated in the enumeration of the hauls by the separation of 27 and 28 and of 20 and 60 from the other numbers. The two deepest hauls (27 and 28), and the two to the westward of Bolt Head (20 and 60), show several differences from the typical shell-gravel hauls.

Bottom-deposit. Clean shell gravel.

Samples taken at 105 and 106 have the following texture :-

I. Stone and Broken Shells

105.

106.

(above $15 \mathrm{~mm}$.) $\quad \ldots \quad \ldots \quad 1.4$ per cent. $\quad 0 \cdot 7$ per cent.

II. Coarse Gravel ... $\quad \ldots \quad \ldots 23 \cdot 1 \quad$ \# $\quad 33.8 \quad$ ”

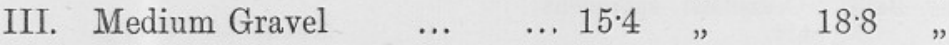

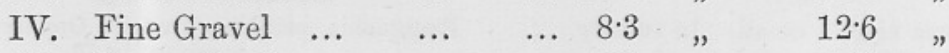

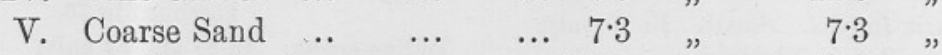

VI. Medium Sand ... $\quad \ldots \quad \ldots \quad 25 \cdot 7 \quad$ " $\quad 19 \cdot 9 \quad$ "

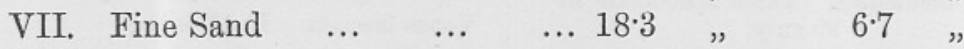

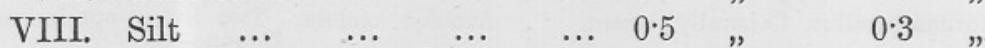

[105. Average grade of sample, 4.498. Percentage of carbonate of 
lime in whole sample, $47 \cdot 26$. Highest percentage occurs in V., which contains 75 per cent. Geologically there is a wide separation between samples 105 and 106 and the other samples taken from the westward. A large percentage of the rock fragments in 105 and 106 is derived from Archean rocks similar to those which constitute the Bolt promontory. Trias is present, but flint, which has suffered considerable surface decay, is also a prominent constituent. The rock fragments in 105 II. are divisible as follows:-Archean (chiefly mica schists), 78.75 per cent.; Flint, 12.74 per cent.; Trias, 8.51 per cent. In 105 VII. 43 foraminifera were found in 0.19 grams (3 grains), or 226 per gram. Rotalia beccarii and Miliolina seminulum greatly predominated; the complete list of species from 105 VI. and VII. being: Rotalia beccarii, Miliolina seminulum, Textularia gramen, Truncatulina lobatula. In all, four species.

[106. Average grade of sample, $3 \cdot 803$. Percentage of carbonate of lime in whole sample, $52 \cdot 77$. Highest percentage occurs in IV., which contains 78.75 per cent. The rock constituents of this gravel are similar to those of 105 , but the proportions are different, the Archean rocks are not so well represented, while flint is much more frequent. The proportions in 106 II. are: Archean, 48.90 per cent.; Flint, 40.44 per cent.; Trias, 10.66 per cent. Fifty-eight foraminifera were counted in 0.26 grams (4 grains) of 106 VII., or 223 per gram. Again, as in 105, Rotalia beccarii and Miliolina seminulum greatly predominate. The species found in 106 VI. and VII. are as follows, arranged in order of frequency:-Rotalia beccarii, Miliolina seminulum, Truncatulina lobatula, Bulimina pupoides, Miliolina bicornis, Textularia gramen, Textularia agglutinans, Discorbina rosacea. In all, eight species.R. H. W.]

Shells were numerous in all hauls, for list see p. 438. In haul 20 stones were taken.

As on the clean broken shell to the west of the Eddystone (XVI.), to which ground the present one has many points of resemblance, the fauna is comparatively poor, especially in the number of fixed species, for the shells present, although numerous, are generally almost clean.

Burrowing species. The typical burrowing species are Spatangus purpureus, Pectunculus glycimeris (abundant), Echinocyamus pusillus, Polygordius, sp., Eupolia curta, and a few Amphioxus lanceolatus.

Fixed species. In the most typical hauls Sarcodictyon catenata, a few encrusting polyzoa, an occasional specimen of Caryophyllia Smithii, with perhaps one or two stray colonies of some hydroid, are all the fixed species constantly met with. In haul 107 the hydroid Campanularia flexuosa was fairly abundant on empty Pectunculus glycimeris shells, and in the same haul and in haul 105 Tubiclava cornucopiae was 
abundant on living specimens of the same mollusc and of Venus fasciata. The deepest hauls (27 and 28) are characterised by large colonies of Alcyonium digitatum, as well as by the hydroids Sertularia abietina and Thuiaria articulata.

Wandering species. As on the Eddystone shell gravel these are not numerous, the only forms generally common being Echinus miliaris, Porcellana longicornis, and a few Ebalia. Occasional specimens of many other species are found, as will be seen from the list below. The presence of several specimens of Fusus islandicus in hauls 105 and 107 is noteworthy, as this is the only locality in the neighbourhood where the species has been found. Asterias glacialis was present only in haul 60 (the most westerly haul on the ground), and has never been taken at any point to the eastward of this ( $c f$. p. 466$)$.

\section{List of Species. Ground XVII.}

ForaminIFERA.

Truncatulina lobatula. On hydroids.

\section{Porifera.}

Cliona celata. Boring shells.

\section{HydrozoA.}

Tubiclava cornucopiae. In 105 and 107 , on living Pectunculus glycimeris and Venus fasciata.

Eudendrium rameum. One colony in each of the hauls 106 and 107 only. In 106 on piece of old Chactopterus tube, in 107 on Pecten opercularis shell.

, capillare. Occasional specimens on other hydroids.

, sp. A small species, not E. capillare. Not uncommon.

Clytia Johnstoni. On other hydroids.

Campanularia Hincksii. On other hydroids. , verticillata. One colony in 28 and one in 60.

,, flexuosa. Common on Pectunculusglycimerisshells in haul 107.

Lafoea dumosa. Recorded in 21 only.

Calycella syringa.

Halecium halecinum. Occasional specimens only. Most plentiful in 60 .

,, Beanii. Very rare.

Diphasia attenuata. In 21 only.

, tamarisca. Young colonies in 28 only.
Sertularia abietina. Common in deepest hauls $(7,27,28)$. Occasional pieces only in remaining ones.

argentea. Occasional specimens frequent.

Hydrallmania falcata. One or two colonies in each haul.

Thuiaria articulata. In the two deepest hauls, 27 and 28 only.

Antennularia antennina. Not common. ,$\quad$ ramosa. In 21 only.

Plumularia pinnata. In 43 and 61 only. Scarce.

Scyphistoma. In 107, on inner side of Pecten opercularis shell.

\section{ActinozoA.}

Alcyonium digitatum. Occasional small colonies only, except in hauls 27 and 28 , the two deepest dredgings on the ground.

Sarcodictyon catenata. Red variety not uncommon on shells.

Caryophyllia Smithii. Occasional specimens on shells. Not frequent.

Epizoanthus incrustatus. Rare. Hauls 21 and 27 only.

Adamsia palliata. Occasional specimens with Eupagurus Prideauxii.

Echinodermata.

Cucumaria lactea. In 20 only, where stones were present.

Solaster papposus. Occasional specimens only. 
Asterias glacialis. In haul 60 only (the most westerly haul).

, rubens. Present in hauls 43,44 , $60,61,62,68$. Two small ones in 107.

Ophiura ciliaris. One or two in 28 and 60 only.

, albida. Occasional specimens.

," affinis. One in 28 only.

Amphiura elegans. Occasional specimens.

Ophiactis Balli. Not frequent. Occasional specimens only.

Ophiocoma nigra. Not frequent. Occasional specimens only.

Ophiothrix fragilis. Not frequent. Occasional specimens only.

Echinus acutus. Not frequent. Occasional specimens only. Several in haul 60 .

, miliaris. Frequent and abundant.

, esculentus. Single specimens in many hauls.

Echinocyamus pusillus. Not uncommon. Spatangus purpureus Generally a number of specimens.

Echinocardium pennatifidum. One in haul 7 only.

\section{Nemertina.}

Eupolia curta. Rare.

Micrura fasciolata.

\section{Polyohaeta.}

Polygordius, $s p$. Plentiful.

Lepidonotus squamatus. Several specimens.

Lagisca propinqua. One recorded in 68 only.

Nereis pelagica. Few.

Amblyosyllis specabilis. Recorded in 27 only.

Glycera, sp. Milk-white in colour.

Chaetopterus variopedatus. Occasional specimens only. Most numerous in 7 .

Pectinaria auricoma. Single specimens frequent.

Amphitrite gracilis. Recorded in 28 only.

Terebellid tubes. Numerous

Sabellaria spinulosa. Recorded in 43 and 27 only.

Protula tubularia. Recorded in 28 only.

Serpula vermicularis. Occasional specimens only, attached to shells.

Hydroides pectinata.
Crustacea.

Eupagurus Bernhardus. Occasional specimens, generally in Buccinum undatum shell. In hauls 106 and 107 in Fusus islandicus. Never with Sagartia parasitica.

, Prideauxii. In 68 and 27 only. In Trochus shell.

, cuanensis. In 28 only.

Anapagurus laevis, In 27 only.

Porcellana longicornis. Plentiful.

Galathea dispersa. Generally not numerous.

Stenorhynchus longirostris. Present in hauls 27,28 , and 60 only.

Inachus dorsettensis. Present in hauls $68,27,28$, and 60 only.

Hyas coarctatus. Not uncommon.

Eurynome aspera. In hauls 6, 27, and 44 only.

Portunus pusillus. Occasional specimens only.

Corystes cassivelaunus. In 27 only.

Atelecyclus heterodon. In 27 and 28 only.

Ebalia tumefacta.

, tuberosa. One or two generally

$, Cranchii. $\}$ in a haul.

Balanus crenatus.

Scalpellum vulgare. Seldom.

Pyrgoma anglicum. With Caryophyllia Smithii.

Ampelisca spinipes.

Gammaropsis erythrophthalmium.

\section{Mollusca. Living.}

Saxicava arctica. Single specimens frequent.

Lyonsia norvegica. One in haul 7.

Venus fasciata. In hauls 6,68 , and 107 . Single specimens.

Astarte sulcata. One in 106 .

Montacuta substriata. With Spatangus purpureus.

Modiola, sp. Small. Occasional.

Arca tetragona. Small. Occasional.

Pectunculus glycimeris. Common, and characteristic of the ground.

Lima Loscombii. In 27 only.

Pecten tigrinus. Single specimens in 21 and 107 only.

" opercularis. Very few or none. Most common in 60.

Anomia ephippium. Frequent. 
Chiton asellus. Common.

Dentalium entalis. In 7,28 , and 20 .

Pileopsis hungaricus. One specimen in 106 and 107 only.

Emarginula reticulata. In 21 and 27 only.

Trochus zizyphinus. One small in 27 only. ,, granulatus. One in 27 only.

Lamellaria perspicua. One in 28 only.

Nassa incrassata. In 20 only.

Buccinum undatum. Not uncommon.

Fusus islandicus. Four or five in 105 and one in 107.

Cypraea europaea. In 27 only.

Tritonia Hombergi. In 27 and 28 only. Dendronotus arborescens. In 28 only.

Doto coronata. In 28 only.

\section{Shells.}

Solen ensis. Few.

Solecurtus candidus. In 20 and 28 ; single valves.

Tellina crassa. One in 105.

Lutraria elliptica. Frequent.

Tapes virginea. Not frequent.

Venus fasciata. Not frequent.

, ovata. Common.

Artemis exoleta. One in 105.

Astarte sulcata. One in 106 only.

Cardium norvegicum. Not frequent.
Pectunculus glycimeris. Numerous.

Pecten maximus. Very few. ,, opercularis. Numerous.

Trochus granulatus. Occasional.

Aporrhais pes-pelecani. In 27 only.

Natica nitida. In 27 only.

Fusus islandicus. In 105 and 107, not uncommon.

Ostrea edulis. Occasional shells.

Polyzoa.

Branched forms almost absent. Incrusting forms numerous. See Table VI.

\section{TUNICATA.}

Styelopsis grossularia. Small, squat variety on shells.

Ascidiella scabra. One or two in 20 and 107 only.

Ciona intestinalis. Frequent, but not numerous. Attached to shells.

Ascidia depressa. A few specimens, attached to shells.

, mentula. One in haul 1 only.

Cephalochorda.

Amphioxus lanceolatus. One in 28 only.

Pisces.

Lepadogaster bimaculatus. One in 106 only.

\section{Ground XVIII. The Prawle Stony Ground.}

Hauls. 2 (O.-tr.), 3 (O.-tr.), 4 (Dr.), 45 (Dr.), 66 (Dr.), 65 (Dr.), 64 (Dr.), 63 (Dr.), 29 (Dr.), 30 (Dr.).

This ground again could probably, with further investigation, be subdivided. The hauls all lie to the eastward of a line passing north and south through Prawle Point, and are characterised by the presence of stones, often of considerable size. The ground is very rough and dredging upon it difficult. No samples of the bottom-deposit were taken with the canvas bag.

Burrowing species. Spatangus purpureus, Echinocyamus pusillus, and occasional specimens of Ebalia were the forms most frequently taken. The boring molluse Pholadidea papyracea was common in the Trias rock of haul 4. Atelecyclus heterodon was taken once, and an occasional burrowing bivalve mollusc was found.

Fixed species. It is, however, by its fixed species that the fauna of this stony ground is specially characterised. The following species, which were absent from the other grounds, or at most only very occasionally met with, were present here, generally attached to stones:Corynactis viridis, Gorgonia verrucosa, Garveia nutans, Tubularia indivisa, 
Diphasia rosacea, Hydrallmania falcata (abundant), Sertularia argentea, and Thuiarix articulata. The presence of large colonies of Alcyonium digitatum may also be noted (see p. 457), as well as the abundance of Sertularia abietina (see p. 453), and Caryophyllia Smithii with the associated barnacle Pyrgoma anglicum.

$W$ andering species. Characteristic of the stony ground are Cucumaria lactea and Ophiocoma nigra. Other species plentiful are Ophiactis Balli, Echinus miliaris, Porcellana longicornis, and Galuthea dispersa, whilst occasional specimens of many forms common on sand and gravel grounds are taken.

\section{List of Species. Ground XVIII.}

\section{Porifera.}

Cliona celata. Boring shells.

\section{HYDROZOA.}

Eudendrium, sp. Small species, not E. capillare, common.

Garveia nutans. In haul 29, on large stone.

Tubularia indivisa. In hanl 29 , on large stone.

Clytia Johnstoni. Common.

Obelia dichotoma. Occasional only.

Campanularia Hincksii. On shells and hydroids.

Campanularia verticillata. In 45 only.

Lovenella clausa. Recorded in 29 only.

Opereularella lacerta. In 29 only.

Lafoea dumosa. Common on other hy. droids. Also var. robuste on shells, \&c.

Calycella syringa. Recorded in 45 only.

Halecium Beanii. A little in haul 4 only. Diphasia rosacea. In 4 and 29.

Sertularia abietina. Common, especially in the deepest hauls.

, argentea. Frequent, but not very abundant.

Hydrallmania falcata. Present in nearly every haul, and often abundant. Attached to stones or sometimes to shells.

Thuiaria articulata. Several pieces in 45 and 63 .

Antennularia antennina. Not frequent. ramosa. Not frequent.

Aglaophenia myriophyllum. In 29 only. Plumularia pinnata. Not common. , setacea. Not common.

Echinodermata.

Cucumaria lactea. One or two in 30 only.
Solaster papposus. Occasional specimens only.

Asterias rubens. Occasional specimens only.

Ophiura albida. One in haul 4.

Ophiactis Balli. Moderately plentiful.

Ophiocoma nigra. In four hauls. Numerous in 30 and 63 . Present in 45 and 66 .

Ophiothrix fragilis. Occasional specimens only.

Echinus miliaris. Frequent,

" esculentus. Occasional small specimens.

Echinocyamus pusillus. In 4 and 45 only. Spatangus purpureus. In 29,45 , and 63 , one or two specimens.

\section{ActinozoA.}

Alcyonium digitatum. Large colonies common, especially in hauls $3,4,45$, and 66 .

Sarcodictyon catenata. In 4 and 63 only, on shells.

Gorgonia verrucosa. In 3 only. Probably growing on rock,

Caryophyllia Smithii. Frequent and plentiful, on stones and shells. With Pyrgoma anglicum.

Corynactis vividis. In 29 and 30, on large stones.

\section{Nemertina.}

Carinella superba.

Micrura purpurea.

$$
, \text { fasciolata. }
$$

Lineus marinus.

Phascolion strombi.

\section{Gephyrea.}

\section{Polychaeta,}

Lepidonotus squamatus. One each in 29 and 45 . 
Eunoe nodosa. One in 45.

Evarne impar. One in 29.

Chaetopterus variopedatus. One or two in 45 and 63 only.

Pectinaria auricoma. Occasional specimens only.

Serpula vermicularis. Recorded in 3 only. Hydroides pectinata. Few only.

\section{Crustacea.}

Eupagurus Bernhardus. Scarce. In haul 45 and 63 only.

Anapagurus laevis. In 3, 4, and 29 only.

Porcellana longicornis. Common.

Galathea dispersa. Common.

Stenorhynchus longirostris. One or two in haul 3 only.

Inachus dorsettensis. One or two in hauls 4 and 45 only.

Hyas coarctatus. Frequent.

Eurynome aspera. Many in 4. Occasional in other hauls.

Pilumnus hirtellus. One in haul 3 only.

Portunus pusillus. In 4 and 45 only.

Atelecyclus heterodon. One or two in 45 only.

Ebalia tumefacta.

, tuberosa. $\}$ Occasional specimens

,, Cranchii.

Ampelisca spinipes.

Melita obtusata. In 29.

Pyrgoma anglicum. Associated with Caryophyllia Smithii.

\section{Mollusca. Living.}

Pholas parva. One specimen in Trias rock. Haul 4.

Pholadidea papyracea. Many in Trias rock. Haul 4.

Saxicava aretica. One or two in 29 only.

Tapes virginea, One small one in 29.

Venus fasciata. In haul 45 only.

Kellia suborbicularis. In haul 30 only.

Modiola, sp. Small, in 30.
Arca tetragona, Occasional small specimens.

Pectunculus glycimeris. One small one in haul 29.

Pecten tigrinus. One in haul 4.

, maximus. One small one in haul 4.

," opercularis. A few in haul 4 only.

Chiton asellus. Common.

,, discrepans. Two in haul 4 only.

Emarginula reticulata. Frequent.

Trochus zizyphinus. Occasional small specimens.

Nassa incrassata. In 45 only.

Buccinum undatum. In 45 only.

Ovula patula. In haul 4.

Doto coronata. In 29 only.

Polycera quadrilineata. In 3 only.

Coryphella Landsburgii. In 30 only.

Shells.

Lutraria elliptica. In 4 only.

Tapes virginea. In 45 only.

Venus fasciata. In 45 only.

Cardium norvegicum. In 45 only.

Pectunculus glycimeris. In 45 and 63 only.

Lima Loscombii. In 4 only.

Pecten tigrinus. In 45 only.

, opercularis. A few generally present.

Murex erinaceus. In 45 only.

Fusus islandicus. In 45 only.

\section{PolyzoA.}

Cellaria sinuosa.

$\left.\begin{array}{l}\text {, fistulosa. } \\ \begin{array}{l}\text { Serupocellaria scruposa. } \\ \text { Bicellaria ciliata. }\end{array}\end{array}\right\}$ In 29 only, a

Bugula turbinata. In 4 and 66 .

Incrusting forms numerous. See Table VI., p. 534.

Tunicata.

Ciona intestinalis. In 63 only.

Ascidia depressa. In 29 only.

\section{SeCtion VI.}

\section{THE DISTRIBUTION OF PARTICULAR SPECIES ON THE GROUNDS UNDER INVESTIGATION.}

In this section the distribution of the individual species of the more important groups on the grounds from the Eddystone to Start is discussed, and the relation of this distribution to changes in the nature of the bottom-deposit pointed out. Notes are also given on some habits of the species which appear likely to influence their distribution. 
In the case of many of the species the geographical and bathymetric distribution is noted, and this is followed by an account of the kinds of deposit upon which the species has been obtained by other observers in different localities. In considering the latter records it must be constantly borne in mind that the terms made use of up to the present time (sand, gravel, mud, etc.) have not been employed in the strict and definite sense which has been given to them in the present paper, and there has been much obvious confusion in their use.

There is, in particular, one source of error which has probably operated very frequently, and by which I was myself several times misled until actual samples of the deposits were obtained with the canvas dredge. Dead shells of bivalve molluses are frequently taken with the two valves united and closed, which, on being opened, are found to be filled with fine mud or muddy sand. No doubt this has often been supposed to indicate that the deposit is mud or fine muddy sand. Such, however, is by no means the case, as shells so filled may be taken on all grounds where a certain proportion of mud is mixed with coarser material, and I have found them particularly numerous on the coarse muddy or sandy gravels. It is very probable that this circumstance has led to many animals being recorded as living on mud, when in reality the bottom-deposit from which they were taken was a muddy gravel or coarse sand.

The explanation of the fact that the shells are filled with mud appears to be that when the bottom is disturbed, either by wave action or by the movements of animals, the mud in the deposit is stirred up, and the muddy water, entering the shells by a narrow aperture, deposits its solid particles, which gradually accumulate inside the shells.

In addition to the error which has probably been made in describing as mud the deposit on grounds where such shells have been dredged, the term sand has clearly been used in a very general sense to include much coarser deposits than those included in the present paper under that head.

\section{FORAMINIFERA.}

[Nomenclature:-Brady, No. 13.]

Truncatulina lobatula. This species is abundant on all hydroid grounds, whether the prevailing species is Sertularella Gayi, Halecium halecinum, or Sertularia abietina, and on the grounds where Cellaria is plentiful. It is found clinging in numbers to the stems of the zoophytes.

Foraminifera were also found in large numbers in the dried samples of the bottom-deposit. The skeletons, many of which doubtless 
contained living protoplasm when captured, were picked out from weighed quantities of the samples and mounted by $\mathrm{Mr}$. Worth, the species being afterwards identified by Mr. Worth and myself working together.

[Although numerically well represented, the Foraminifera do not appreciably affect the percentage of carbonate of lime in the sample. Thus, although 103 VII. with 203 foraminifera in 0.13 grams has the high percentage of $40 \cdot 15$, this is due to the abnormal amount of shell in the coarser grades of the sample; for 83 VII. has an even higher percentage of 47.83 of carbonate of lime with only 93 foraminifera to 0.13 grams, and other similar examples might be instanced.

This is not surprising when it is remembered that it would take to cover 13 sq. cms. about 5500 grains of sand of the largest size that could pass a half-millimetre mesh, while the actual number of grains present in such an area from most of the fine sands would probably be from 16,000 to 20,000 . The numerical proportion of 200 foraminifera would thus be small, and their chambered structure, as compared with the solidity of the sand grains, would render their proportionate weight even smaller.

Foraminifera are found in the medium sands (Grade VI.), the fine sands (Grade VII.), and the silts (Grade VIII.). They are more numerous in VII. than in VI., and more numerous in VI, than in VIII. Only the Foraminifera from Grades VI. and VII. have been thoroughly examined. These have been recorded in Section V., under the headings of the different grounds.

The silts contain numerous foraminifera of small species and small specimens of foraminifera of large species. As a result of floating them from the silts it was found that many species sparingly represented in either grades VI. or VII. were all present in almost every sample of silt, as well as species entirely absent from grades VI. and VII.

Among the species sparingly represented in VI. and VII., but frequent in the silts, are Globigerina bulloides (very frequent), Bulimina. pupoides, Lagena striata, Bolivina dilatata, Polymorphina lactea, and Spirillina vivipara.

The species present in the silts but not found in VI. and VII. are Cristellaria crepidula, Nodosaria scalaris, Nodosaria laevigata, Nodosaria communis, Bolivina punctata, Haplophagmium canariensis, and Lagena lagenoides.

In some few cases a census was taken of the number of Foraminifera to be found in 13 centigrammes by weight of fine sand, spread out to cover 13 sq. cm. in such manner as to present a single layer of sand 
grains lying as nearly as possible side by side without overlap. The figures were as follows:-

102 VII., 13 c. grms. by weight, 48 foraminifera.

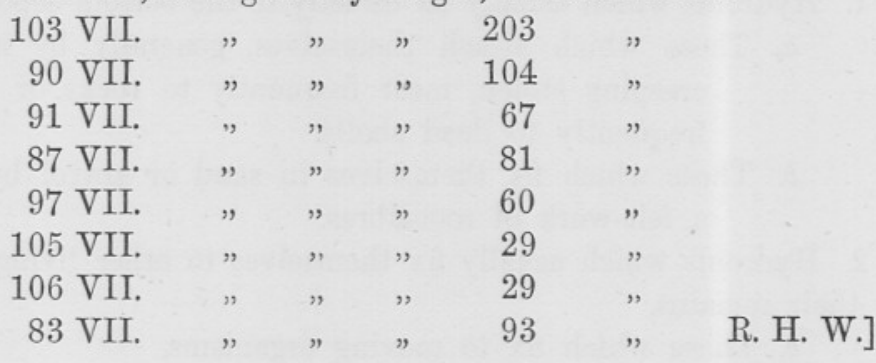

\section{PORIFERA.}

The only two species of sponges of which satisfactory records were kept are Suberites domuncula and Cliona celata. The sponge fauna was nowhere numerous on the grounds; but in addition to the above, two or three other unidentified species were occasionally taken.

Suberites domuncula was met with, forming the dwelling of the hermit crab Eupagurus cuanensis.

Cliona celata. The importance of this species is very great, for, boring as it does in molluse shells of all kinds, it is the chief agent which brings about their disintegration, and prevents their continued accumulation on the sea-floor. On all the coarse grounds in the neighbourhood of the Eddystone there are few shells, with the exception of those which are obviously quite recently dead, which have not been attacked to a greater or less extent by Cliona, and a large number are reduced to what is little more than a framework held together by the sponge.

\section{HYDROZOA.}

[Nomenclature:-Hincks, British Hydroid Zoophytes.]

In this group I have received much assistance from my friend Mr. E. T. Browne, the specimens in a number of hauls having been identified by him. For geographical distribution I have relied largely on Hartlaub (No. 38).

The influence of the bottom-deposit on the distribution of hydroids. The Hydrozoa being all fixed organisms, the nature of the bottomdeposit has in most cases, either directly or indirectly, a very great influence on their distribution, and in an area such as that examined during the present investigation, where the remaining physical conditions to which the grounds are subjected are practically the same for all, this influence can be very largely traced.

Considered from the point of view of their modes of attachment, 
and of the nature of the objects to which they fix, several kinds of hydroids may be distinguished, namely :-

1. Hydroids which usually fix directly to the bottom-deposit.

$a$. Those which attach themselves, generally by means of a creeping stolon, most frequently to rocks or stones, less frequently to dead shells.

b. Those which fix themselves in sand or gravel by means of a felt-work of root-fibres.

2. Hydroids which usually fix themselves to other living organisms or their remains.

c. Those which fix to moving organisms.

d. Those which fix to stationary organisms or remains of organisms.

It must not, of course, be supposed that any species of hydroid is entirely confined to one only of these manners of fixing, but it will be found that for each species there is one (or in some cases possibly two) of these ways of attachment to which its structure is specially adapted, and that in the great majority of instances, more particularly where the species is exceptionally abundant, it will be fixed in this way.

a. Hydroids attaching themselves to rocks or stones. The nature of the rock is of importance in this connection, though the amount of evidence at present available on this point is not sufficient to render profitable a detailed discussion of the matter.

Of the hydroids considered in the present paper, those most typical of this class are Garveia nutans, Tubularia indivisa, ${ }^{*}$ Aglaophenia tubulifera, and Hydrallmania falcata, the latter species being most frequently attached to stones or gravel. Such hydroids are plentiful on rocky or stony grounds.

b. Hydroids fixing themselves in sand or gravel by a felt-work of root-fibres. Examples of this class are Aglaophenia myriophyllum, Antennularia antennina, and Antennularia ramosa. The texture of the bottom-deposit is a most important factor in determining the distribution of such forms, as will be seen especially by referring to the account of the distribution of Aglaophenia myriophyllum. Antennularia antennina and $A$. ramosa are perhaps not such good representatives of the class as the species first mentioned, since they are also rather frequently found attached to shells, especially in shallow water.

c. Hydroids which fix to moving organisms. Hydractinia echinata, Heterocordyle Conybeari, Perigonimus repens represent this class. The habit has evidently been acquired by the hydroid by reason of the advantages in the matter of food-supply offered by the constant movement of the host.

$$
\text { * } C f \text {. p. } 448 .
$$


The distribution of such species depends upon that of suitable hosts, and since the hosts are all wandering animals, the nature of the bottom-deposit, when it is once sufficiently firm to support them, has little direct effect on their distribution.

d. Hydroids which generally fix themselves to stationary living organisms or remains of organisms. We may to some extent distinguish between those which most frequently fix (1) to dead shells of molluscs,* (2) to sea-weeds, (3) to other zoophytes, (4) to the membranous or leathery tubes of polychaetes, (5) to living lamellibranch molluses. Typical examples of (1) are Eudendrium rameum and ramosum, Campanularia verticillata (?), and Lafoea dumosa, var. robusta; of (2) Sertularia pumila and Obelia geniculata; of (3) Eudendrium capillare, Coppinia arcta, Halecium tenellum; of (4) Halecium halecinum, Sertularella Gayi, Lar sabellarum; of (5) Tubiclava cornucopiae. The distribution of these forms depends almost entirely upon the distribution of their hosts, which are themselves fixed organisms generally directly attached to the bottom, whose distribution therefore is largely influenced by the nature of the bottom-deposit.

Tubiclava cornucopiae (Table VI., p. 529). This species was abundant on the Bolt Head Shell Gravel (Ground XVII). In haul 105, in which Pectunculus glycimeris was abundant, nearly every living specimen of that mollusc had Tubiclava growing in considerable quantity on the posterior margin of the shell. In haul 107 on the same ground Tubiclava cornucopiae was growing on the posterior end of living Venus fasciata.

The hydroid was also present on the fine sand south of the Eddystone (Ground VI., haul 102), growing on the posterior end of the shell of Dentalium entalis.

Distribution. Geographical. Shetland (Norman, No. 90); Northumberland (Alder); Plymouth (Garstang, No. 27, p. 334; No. 28, p. 212).

Depth. 15 fathoms (Garstang) to 80-100 fathoms (Norman).

Habitat. Norman found his specimens growing on Astarte sulcata and Dentalium entalis. In every instance the molluse was living and the hydroid was on the posterior extremity of the shell, where, as Norman says, "it would receive the benefit of the aqueous currents caused by the mollusc, which, while providing for its own necessities, thus unwittingly performed the kindly office of feeding its hungry neighbour." Alder's specimens were also found on the posterior end of Dentalium entalis.

Garstang found the species upon Aporrhais pes-petecani shells inhabited by Phascolion strombi, and subsequently also on shells of Turritella inhabited by the same Gephyrean. These specimens were obtained in 15-25 fathoms, south of the Plymouth Mewstone. The species is still frequently taken in this locality on a bottom of clean shell gravel.

Speaking of Pectunculus glycimeris, Gwyn Jeffreys (No. 55, p. 168) says, "The anterior side of the shell, while the animal is alive, is frequently fringed with the tubes of a

* Those hydroids which fix on shells are less clearly marked as a separate class, probably since a dead shell offers conditions very similar both to those of stones and of other living organisms.

NEW SERIES. - VOL. V. NO. 4. 


\section{ON THE FAUNA AND BOTTOM-DEPOSITS NEAR THE 30-FM. LINE}

Hydroid polype (one of the Tubulariidae), which seems to take advantage of the strong gyratory current produced by the mollusc for its own food-seeking purpose." It is probable that the reference is to the present species, though in my specimens the hydroid was always on the posterior end of the shell.

Hydractinia echinata (Table VI., p. 529). Generally on Buccinum undatum shells occupied by Eupagurus Bernhardus, occasionally (haul 93) on shell occupied by E. Prideauxii. The presence of Hydractinia appears to be rather more frequent on the fine sand than on the coarser grounds.

Distribution. Geographical. Greenland, Iceland, North Sea, British coasts, Normandy and Brittany, and North America (Agassiz). [Fide Hincks, No. 46, and Hartlaub, No. 38.]

Depth. Low-water to 90 fathoms.

Habitat. On Buccinum undatum, Fusus corneus, Turritella communis, Nassa reticulata, Littorina, Natica, Trochus zizyphinus (Hincks). On Mytilus edulis and on stones (Hartlaub).

Eudendrium rameum (Chart III.). Specimens of $E$. rameum were obtained only on the Bolt Head Shell Gravel, in hauls 106 and 107 (Ground XVII.). In 106 a fine colony was growing on an old fragment of the leathery tube of Chaetopterus, and in 107 another fine colony was found on a shell of Pecten opercularis.

Distribution. Geographical. West Greenland, Kara Sea, Norway, Baltic, North Sea, British Seas, Mediterranean, and Kerguelen (Challenger). [Fide Hartlaub, No. 38.]

Depth. 5-105 fathoms (Challenger, No. 3).

Habitat. On shells, stones, etc. (Hincks, No. 46).

Eudendrium ramosum (Chart III.). Generally growing on shells or on other hydroids. The species is far more frequent and abundant on sandy grounds than on the gravels. It was most numerous on Grounds I., III., IV., VII., and XII.

Distribution. Geographical. Greenland, Norway, North Sea, British Seas, Mediterranean (Hartlaub, No. 38).

Depth. Low-water to 542 fathoms (Porcupine, Allman, No. 4).

Habitat. On shells and on Laminaria roots (Hincks, No. 46; Hartlaub, No. 38).

Eudendrium capillare and E. sp. (Table VI., p. 529). The true Eudendrium capillare was met with on several grounds, generally growing on other hydroids, sometimes on worm tubes or shells. A small Eudendrium of a rather more robust character was also frequently taken in similar situations, but there is some doubt as to whether this is a distinct species.

Distribution. Geographical. Norway, Baltic, North Sea, British coasts (Hartlaub, No. 38).

Depth. 4 to 30 fathoms (E. J. A.).

Habitat. On Antennularia ramosa, Delesseria sanguinea, on Salicornaria farciminoides (=Cellaria fistulosa) (fide Hincks).

Perigonimus repens (Table VI.). A good colony of this hydroid was found growing on the claw of Eupagurus Bernhardus, in haul 104, on the fine sand of Ground II. The species was not found on any other ground. 
Distribution. Geographical. Norway, Baltic, Kattegat, North Sea, British Coasts, Mediterranean (Hartlaub, No. 38).

Depth. Shallow water to 33 fathoms (E. J. A.).

Habitat. On Sertularians and on the Spider Crab (Wright). On Dentalium entalis, Fusus antiquus, Turritella communis, and on stones (fide Hincks, No. 46). On Mya arenaria, on mussel shells, frequent on Nucula nucleus (Hartlaub). On Turritella, Chiton, Leda, Nucula, and Dentalium (Levinsen, No. 66). Growing on legs of a crab and on Turritella shells at Plymouth (Bourne, No. 12). It is also frequently taken at Plymouth on Nassa reticulata. Perigonimus repens is clearly a species which fixes itself most frequently to living crustaceans and molluses.

Garveia nutans. On the Prawle Stony Ground only, in haul 29 (depth, 30 fathoms), growing on Tubularia indivisa, which was itself fixed to a large stone.

Distribution. Geographical. Scottish Coasts, Shetland, Morecambe Bay (Hincks, No. 46, and Allman, No. 2); Hilbre Island, Mouth of Dee; Plymouth (Garstang).

Depth. Between tide-marks (Allman) to 30 fathoms (E. J. A.).

Habitat. On rocks, zoophytes, and sea-weeds (Allman).

Heterocordyle Conybeari. On the fine sand of Ground I., in haul 51 only, fixed to shell of Buccinum undatum inhabited by Eupagurus Bernhardus.

Distribution. Geographical. Glengariff Harbour, co. Cork, Oban (Allman and Hincks).

Depth. Near low-water mark (Hincks) to 30 fathoms (E. T. B.).

Habitat. On univalve shells tenanted by Hermit Crabs (Allman). On Buccinum (Hincks). Mr. E. T. Browne has found the species abundant in Plymouth Sound on the shells of living Nassa reticulata. Heterocordyle Conybeari is clearly a species which fixes itself to living and freely-moving animals.

Bougainvillia ramosa (Chart III). As will be seen from the Chart, in the area described in this report, this species is practically confined to the fine sand grounds, on which it is frequently met with, though not in large quantities. The only exception to this was in haul 84, on Ground XI., where the bottom-deposit is coarse gravel mixed with fine sand, and in this haul only one piece was seen. It was generally found growing on polychaete tubes or on other hydroids.

Distribution. Geographical. Baltic, North Sea, British Coasts.

Depth. Low-water (Allman, No. 2) to 26 fathoms (Hartlaub, No. 38), 35 fathoms (E. J. A.).

Habitat. On shells and stones and on other zoophytes (Hincks). On Virgularia mirabilis (Dalyell). Allman records it on rocks near low-water. On Hyas aranea (Apstein). Hartlaub found it at Heligoland, in $8 \frac{1}{2}$ fathoms, on sandy ground, with many Ascidians. By the Pommerania expedition it was dredged on ground described as muddy, in 26 fathoms (Schulze, No. 105).

Tubularia indivisa (Table VI., p. 529) was taken only on the Prawle Stony Ground (XVIII.), where it was growing on a large stone.

Distribution. Geographical. Alaska, Greenland, North Cape, White Sea, Norway, Baltic, North Sea (rare at Heligoland), British Coasts, Bay of Biscay (fide Allman, No. 2, and Hartlaub, No. 38), Mediterranean (Pruvot, No. 98).

Depth. Low-water to 55 fathoms.

Habitat. Tubularia indivisa is most frequently found on rocky and stony ground. It is often taken on floating objects, such as buoys, 
hulks, etc. It also, however, is not unfrequently met with, according to various authors, on fine sandy or muddy ground. Hincks (No. 46) quotes Thomas as saying that "on the oozy bottom which lies outside a line drawn between Flamborough Head and the Staples" it grows to a very large size. According to the same author Forbes found it in Rothesay Bay, flourishing, as it seemed, "upright, on a muddy ground, like a flower, fixed by the tapering root-like termination of its horny case." Schulze (No. 105) records it in a number of the Pommerania hauls, from bottoms of sand and shell at depths from 23 to 50 fathoms. The entire absence of the species from all the sand and gravel grounds examined during the present investigation is therefore noteworthy. Indeed, I know of no such locality in this neighbourhood where the species lives.

Clytia Johnstoni (Table VI.). Abundant on all grounds where other hydroids or Cellaria are common. It appears to grow less frequently upon Halecium halecinum and Beanii than on Sertularians and Hydrallmania.

Distribution. Geographical. Norway to the Mediterranean, Baltic, Greenland, Alaska, east coast of North America (fide Hartlaub, No. 38).

Depth. To 50 fathoms (?).

Habitat. On algae and hydroids.

Obelia dichotoma (Table VI.). This species has been met with on fine sand grounds in the neighbourhood of the Eddystone, and occasionally on the Bolt Head Shell Gravel and the Prawle Stony Ground. It was found growing on Pecten opercularis shells, on other hydroids (Hydrallmania, Bougainvillia, Sertularia argentea), and on Cellaria.

Distribution. Geographical. Norway, Baltic, British Seas to Mediterranean (fide Hartlaub, No. 38).

Depth. 6-29 fathoms.

Habitat. On shells, algae, and other zoophytes.

Obelia longissima was only found in haul 80 on Ground VII., south of the Eddystone.

Distribution. Geographical. Cireumpolar, Norway to British and Belgian Coasts (fide Hartlaub, No. 38).

Depth. To 20 fathoms (Hartlaub).

Campanularia Hinclesii is generally distributed on the grounds examined, growing sometimes on shells, sometimes on Cellaria, and probably less frequently on hydroids.

Distribution. Geographical. British Coasts (Hincks, No. 46).

Depth. 10 or 20 fathoms to deep water (Hincks).

Habitat. On zoophytes, etc.

Campanularia verticillata (Table VI.). Occasional specimens were taken on the fine sand grounds, I., III., and VI., in the neighbourhood of the Eddystone. A fine colony was taken growing on a stone in haul 45 on the Prawle Stony Ground (XVIII.), and it was also met with in hauls 28 and 60 on the Bolt Head Shell Gravel. 
Distribution. Geographical. Kara Sea, White Sea, North Cape, Norway, Baltic, North Sea, British Coasts to Mediterranean; Greenland, Labrador, Nova Scotia, Massachusetts (fide Hartlaub, No. 38).

Depth. To 300 fathoms (Sars, fide Allman, No. 2).

Habitat. On shells and other hydroids (Hincks, No. 46, Schulze, No. 105).

Campanularia flexuosa. A hydroid was very abundant in haul 107 on the Bolt Head Shell Gravel (XVII.), growing on dead shells of Pectunculus glycimeris. The specimens were without gonophores, but were identified independently by Mr. Browne and myself as C. flexuosa. C. flexuosa was not taken in any. other haul.

Distribution. Hincks (No. 46) says it is confined to the littoral region, and is extremely common on all parts of our coasts. Mediterranean (Carus, No. 14).

Lovenella clausa. Growing on Tubularia indivisa, in haul 29, on the Prawle Stony Ground (XVIII.).

Distribution. On stones in Torbay, 10 fathoms (Hincks). On Fuci from stony ground off the coast of Sweden (Lovén). Taken once at Heligoland (Hartlaub).

Opercularella lacerta. Growing on Tubularia indivisa, in haul 29, on the Prawle Stony Ground (XVIII.).

Distribution. Between tide-marks and in moderate depths not uncommon. British Coasts and Belgium (fide Hincks).

Lafoea dumosa. The creeping variety of $L$. dumosa* was present on practically all grounds, growing on shells and on other hydroids when the latter were present. The branched variety (var. robusta) was frequently met with, especially upon fine sand grounds, attached to shells or polychaete tubes. The Neomenian Dondersia banyulensis was often found associated with this variety.

Distribution. Geographical. White Sea, North Cape, eastern side of Atlantic to Mediterranean (Pruvot, No. 98), Greenland, Alaska, Labrador and western side of Atlantic, West Indies, Chili (fide Hincks, No. 46, and Hartlaub, No. 38).

Depth. To 450 fathoms (Challenger, Allman, No. 3).

Lafoea fruticosa. This species was taken occasionally on different fine sand grounds (I., III., IV., VII.), and a fine colony was also found in haul 84 on the coarse gravel and fine sand north-west of the Eddystone (Ground XI.).

Distribution. Geographical. North Cape, Iceland, Norway, British Seas (fide Hincks), Strait of Magellan (Challenger, Allman, No. 3).

Depth. To 100 fathoms (Iceland, Hincks).

Habitat. On shells and zoophytes.

Calycella syringa. This was recognised occasionally on the Bolt Head Shell Gravel and on the Prawle Stony Ground, growing on Pecten opercularis shells, on Sertularia abietina, and on Hydrallmania falcata.

Distribution. Geographical. White Sea, Iceland, Greenland, Alaska, North Sea, British Coasts, north coast of France (fide Hartlaub, No. 38; and Hincks, No. 46), Mediterranean (Carus, No. 14).

* What we have regarded as the creeping form of $L$. dumosa has probably often been the form recorded by other authors as Filellum serpens, but we have not felt able to distinguish between the two. We have often compared the Plymouth Lafoea with Hincks' figures of Filellum serpens, but up to the present have not seen anything like Filellum as figured. 


\section{Depth. To 42 fathoms (Hartlaub).}

Habitat. On other zoophytes and sea-weeds, very common (Hincks).

Calycella fastigiata. This was recognised in haul 75 (Ground VII.).

Distribution. Scotland, Cornwall (Norman, No. 90 ; Hincks, No. 46), North Sea (Schulze, No. 105). Growing on other hydroids. To 81 fathoms (Porcupine, Allman, No. 4).

Cuspidella costata. Recognised in haul 81 on the fine sand ground (I.). Distribution. Whitby, Yorkshire. On Syncoryne eximia (Hincks).

Trichydra pudica. This species was found by Mr. Browne growing on Halecium halecinum and on a Pecten opercularis shell in haul 97 (Ground XV., fine gravel).

Distribution. Found by Wright in the Firth of Forth, on a small shell. There are no other records (Hincks, No. 46).

Coppinia arcta (Table VI.). Abundant on the fine sand grounds, especially on Lafoea dumosa (var. robusta) and on Sertularia abietina. Whenever special attention has been paid to the point, I have always found the creeping variety of Lafoea dumosa growing on the branch of Sertularia abietina upon which the Coppinia was found. As the gonothecæ of Lafoea dumosa are quite unknown, the constant association of Coppinia arcta with it naturally suggests the idea that the latter might be the reproductive stage of Lafoea.*

Distribution. Geographical. Circumpolar (Norman), Norway, British Seas, Pas-deCalais (fide Hartlaub, No. 38).

Depth. To 50 fathoms (Schulze).

Habitat. Growing on Sertularia abietina and on Hydrallmania falcata (Hincks). Hartlaub also found it on these two hydroids, generally associated with Filellum serpens. Schulze (Pommerania, No. 105) records it on Hydrallmania falcata.

Halecium halecinum (Chart II.). The distribution of this hydroid is both interesting and significant. The species is very abundant on the grounds to the westward of the Eddystone, but is scarce or entirely absent on the remaining grounds. The abundance of Halecium is specially characteristic on the mixed coarse gravel and fine sand of Grounds IX. and XI., on the finer gravel of Ground XIV., and on the coarse sand of Ground VII. As will be seen from the chart, the species extends from these grounds on to those which immediately surround them, in what appears to be diminishing quantity according to the distance from the centre of abundance. Thus on the fine sand of Ground VI. it is fairly abundant, on the coarse sand of Ground IV. it is still met with in some quantity, on the fine sand of Ground III. it is scarce, whilst on the fine sand of Ground I. it is represented by two colonies only, one in haul 92 and one in haul 82 . On the fine gravel of Ground XII., again, the species is present, but in much

* Since the above was in type C. C. Nutting's paper on "Hydroids from Alaska and Puget Sound" (Proceed. U.S. Nat. Museum, vol. xxi.) has come to hand, in which it is maintained that Coppinia arcta is in reality the gonosome of Lafoea, a view which appears to have been definitely held by Levinsen in 1893. (Meduser, Ctenophorer, og Hydroider fra Grönlands Vestkyst, Copenhagen, 1893.) 
smaller quantity than on the neighbouring coarse gravel of Ground XI. Ground X., as Chart II. shows, is surrounded by grounds on which H. halecinum is abundant. As has been already explained (p. 416), this ground is occupied almost exclusively by Ophiothrix fragilis, but occasional specimens of $H$. halecinum were taken upon it in some hauls. A single specimen of the hydroid occurred in haul 10 on the clean shell gravel of Ground IX., close to the Eddystone rocks, a ground upon which hydroids were practically absent. It was occasionally taken on the Bolt Head Shell Gravel, but never on the Prawle Stony Ground.

On the grounds where the species was most abundant the specimens of Halecium halecinum were in by far the greater number of instances fixed to the leathery tubes of Chaetopterus, the distribution of which, as will be seen by comparing Chart II. with Chart X., is practically identical with that of the hydroid we are considering. But in addition to the Chaetopterus tubes the hydroid was also found, though much less frequently, attached to shells or (in haul 100 only) to stones. The shells of Tapes virginea and Pecten opercularis were the most common ones used by the hydroid, but exceptionally fine colonies were sometimes found attached to the flat upper valve of living Pecten maximus. This latter molluse was generally present on the Halecium grounds, but only a comparatively small proportion of the specimens had colonies of the hydroid growing upon them.

Undoubtedly the presence of Chaetopterus in numbers, by offering a suitable fixing place for the hydroid, is an important factor in determining the abundance of Halecium halecinum upon the grounds where it is found in quantity. At the same time it is not the only cause, since Chaetopterus is obtained in numbers on a ground some four miles south-west of Rame Head, where Halecium halecinum is by no means plentiful.

Distribution. Geographical. North Cape, Norway, Baltic, Kattegat, North Sea, British and French Coasts, Mediterranean, Massachusetts Bay (fide Hartlaub, No. 38).

Depth. 12-50 fathoms (Sars, fide Hartlaub).

Habitat. On shells, stones, ete., in both shallow and deep water, but more usually the latter (Hincks). Schulze (No. 105) states that in the Pommerania dredgings the species was found on bivalve shells, worm tubes, etc. It was taken six times on stony ground or sand with stones, four times on sand and shell, and twice on mud.

Halecium Beanii (Table VI., p. 529) was met with on all the grounds upon which $H$. halecinum was found, although it was by no means so abundant as the latter species on the grounds to the westward of the Eddystone. It was found, so far as I remember, for I have no definite records on the point, more frequently upon shells than on Chaetopterus tubes, differing in this respect from $H$. halecinum.

Distribution. Geographical. British Seas; Azores (450 fathoms, Challenger, Allman, No. 3), south-east coast of Australia (150 fathoms, ditto); Mediterranean (Carus, No. 14). 


\section{Depth. To 150 fathoms.}

Habitat. On shells, etc., and very often parasitic on other zoophytes, from moderate depths to deep water (Hincks, No. 46). The Pommerania took it on a bottom of sand, and on sand, shell, and small stones (Schulze, No. 105).

Halecium labrosum was identified by Mr. E. T. Browne, in hauls 73 and 75 , on Grounds XIV. and VII., west and south-west of the Eddystone.

Distribution. Geographical. North Sea, Scotland, Shetlands (fide Hartlaub, No. 38). Very common at Heligoland, especially on Phallusia (Ascidiella) virginea. Allman (No. 2) states that this is a northern form, confined to the north coasts of the British Isles. Mediterranean (Carus, No. 14).

Halecium tenellum was recognised only in haul 29 on the Prawle Stony Ground, growing on the stem of Tubularia indivisa. In haul 77 on Ground IV. a fragment of a small Halecium, which was probably this species, was seen growing on Cellaria.

Distribution, ETc. Salcombe Bay, Devon, on Salicornaria farciminoides (=Cellaria fistulosa); Filey (T. H.); Northumberland, on Tubularia indivisa and Sertularia abietina, from deep water (J. A.) [Hincks, No. 46].

Sertularella Gayi (Chart II.). In contradistinction to Halecium halecinum this species is specially abundant on the fine sand grounds, where it forms one of the most characteristic features of the fauna. It is most abundant on the fine sand grounds III. and IV. to the eastward of the Eddystone, and on Grounds VI. and VII. to the south. It is present in quantity also on the fine sand of the inner and outer trawling ground (I. and II.). On the coarser grounds to the westward of the Eddystone, it is still moderately plentiful on the coarse gravel mixed with fine sand of Grounds XI. and XII. It is scarce on the remaining grounds in the neighbourhood of the Eddystone (one or two colonies at most in a haul and absent in many hauls), and has never been taken on the Bolt Head Shell Gravel (XVII.) or the Prawle Stony Ground (XVIII.).

On the grounds upon. which it is abundant Sertularella Gayi is most frequently attached to the membranous tubes of Thelepus. It is also found less frequently attached to shells.

A group of animals of the following kind, in which $S$. Gayi plays an important part, is exceedingly frequent on the grounds where this hydroid is abundant:- The tube of the polychaete Thelepus serves as a base from which the hydroid Sertularella Gayi springs. Attached to the lower portion of the stem of the hydroid are the Ascidian Ascidiella scabra and the Polychaete Sabella (pavonina?), as well as the barnacle Scalpellum vulgare. Attached also to the stem of the Sertularella will probably be some of the smaller creeping hydroids, especially Clytia Johnstoni, together with a number of foraminifera belonging to the species Truncatulina lobatula. 
Distribution. Geographical. British Seas and coast of Normandy (Hincks), New Zealand (Allman, No. 2).

Depth. To 374 fathoms (Allman, No. 4, Porcupine).

Sertularella polyzonias (Table VI., p. 530). In the earlier hauls I did not distinguish between $S$. Gayi and S. polyzonias, until the difference between the two forms was pointed out to me by Mr. Browne. The distribution of $S$. polyzonias is practically identical on the Eddystone Grounds with that of $S$. Gayi, though it is much less frequently met with, generally not more than two or three pieces being found amongst a large mass of $S$. Gayi.

Distriburion. Geographical. Kara Sea, Norway, Kattegat, Baltic, North Sea (not frequent at Heligoland), British Coasts, Madeira, Mediterranean, Alaska, Greenland, east coast of United States, Florida, Australia and New Zealand, Chili, South Africa (fide Hartlaub, No. 38 ; Allman, No. 2, p. 160 ; and Hincks, No. 46).

Depth. To 374 fathoms (Allman, No. 4, Porcupine).

Habitat. On shells, sea-weeds, etc. (Hincks).

Diphasia rosacea (Table VI.). Only occasionally met with, in hauls 82 and 99 on the Eddystone Grounds, 4 and 29 on the Prawle Stony Ground.

Distribution. Geographical. Faröe, British Coasts, North France, Massachusetts Bay (fide Hartlaub, No. 38).

Depth. Tide-marks to 50 fathoms (Hincks, No. 46).

Habitat. On other zoophytes (chiefly) and on shells. Hartlaub found it on Tubulario indivisa and on Sertularia cupressina. Schulze (No. 105) records it three times in the Pommerania dredgings on sand and shell. Packard found it very abundant on gravelly bottom, in 50 fathoms, in Straits of Belle Isle.

Diphasia attenuata. In hauls 23 and 24 on the fine sand of the outer trawling ground (II.), and in haul 21 on the Bolt Head Shell Gravel. Never plentiful.

Distribution. British Coasts, generally on other zoophytes (Hincks, No. 46); Australia (von Lendenfelt and Hincks), South Africa (Allman, No. 2).

The Pommerania took it twice on sand and shell, once on small stones.

Diphasia tamarisca. In haul 99 south of the Eddystone, and in haul 28 on the Bolt Head Shell Gravel. Small colonies only.

Distribution. British Coasts, Bay of Biscay, Grand Manan, Massachusetts Bay (Hincks), Mediterranean (Carus, No. 14). On shells and stones from deep water. The Pommerania took it once on sand, shell, and small stones in 30 fathoms (Schulze, No. 105).

Sertularia abietina (Chart II.). This species is characteristic of the fine sand of the outer trawling ground (Ground II.), where it is taken in quantity. It is not present on the fine sand of the inner trawling ground (Ground I.), nor on any of the grounds in the neighbourhood of the Eddystone. It is frequently taken on the Bolt Head Shell Gravel and on the Prawle Stony Ground, being abundant in some of the deeper hauls (especially hauls 7, 28, 4, and 45).

In haul 28 it was growing largely on Pecten opercularis shells, but I unfortunately have no notes on its attachments in other hauls. 
Distribution. Geographical. Kara Sea, White Sea, North Cape, Norway, Baltic, North Sea, British Coasts, Bay of Biscay, Mediterranean. Iceland, Greenland, Labrador, Newfoundland (fide Hincks, No. 46, and Hartlaub, No. 38). South Africa (Allman, No. 2, p. 158).

Depth. 5-75 fathoms (Allman, No. 4, Porcupine).

Habitat. On shells, stones, etc., from deep water (Hincks). Attached to living molluses (M'Intosh, St. Andrews). Schulze (No. 105) records it from the Pommerania dredgings nine times on hard or coarse ground, twice on mud or sand in 30 and 50 fathoms.

Sertularia argentea (Table VI.). This species was not unfrequently met with on both coarse and fine grounds, though never in quantity. It was growing on Pecten opercularis shells, on stones, and on other hydroids (Diphasia tamarisca).

Distribution. Geographical. North Cape, Kattegat (Levinsen, No. 66), British and French Coasts, Adriatic, Greenland, Labrador, east coast of United States, South Africa (fide Hincks, No. 46).

Depth. 8-50 fathoms.

Habitat. On shells, stones, etc., chiefly from deep water.

Hydrallmania falcata (Chart III.) was abundant on the Prawle Stony Ground (XVIII.) and moderately plentiful on the Bolt Head Shell Gravel (XVII.). On most of the fine sand grounds and coarse grounds in the neighbourhood of the Eddystone occasional specimens were taken, but on none of these was it at all abundant.

The hydroid was generally attached to stones, occasionally to shells. I have never seen this species attached to polychaete tubes.

Distribution. Geographical. White Sea, Norway, Baltic, North Sea, British Coasts, Gulf of St. Lawrence, east coast of United States, South Africa (fide Hincks, No. 46, and Hartlaub, No. 38).

Depth. 12-542 fathoms (Porcupine, Allman, No. 4).

Habitat. On shells and stones in the coralline zone (Hincks). On dead shells (Cyprina islandica, Ostrea edulis) in Kattegat (Levinsen, No, 66). Schulze (No. 105) records Hydrallmania in the Pommerania dredgings four times on coarse bottom (with small stones), eight times on sand and shell, and once on mud.

Thuiaria articulata (Chart IV.). Several colonies in hauls 27 and 28 on the Bolt Head Shell Gravel (XVII.), and several in hauls 45 and 63 on the Prawle Stony Ground (XVIII.) The species was never met with on the Eddystone Grounds. Attached to stones or shells.

Distribution. Geographical. British Seas (Hincks, No. 46), Mediterranean (Carus, No. 14).

Depth. To 632 fathoms (Porcupine, Allman, No. 4).

Habitat. On stones and shells from deep water (Hincks). Schulze (No. 105) records it once only in the Pommerania dredgings on a bottom of sand, shell, and small stones.

Antennularia antennina (Chart IV.). This is typically a sand species, possessing at the base of the stalk a felt-work of root-fibres, by means of which it fixes itself in the sand. It is, however, not unfrequently also found attached to shells. It is most abundant on the fine sand grounds, I., II., V., and VI., and on Ground XII., where the bottom is medium gravel mixed with muddy sand. It is rare on the very fine sand of the outer trawling ground (II.), not very plentiful 
on the fine gravel of Ground XIV., the coarse gravel mixed with sand of Ground XI., and on Ground VII. It is only occasionally met with on Grounds X., XIII., XV., and on the Bolt Head Shell Gravel (XVII.) and Prawle Stony Ground (XVIII.).

On the whole the species, in the area examined, seems to flourish best in the coarser sand grounds, being scarce on gravels and stony ground, and also on very fine sand.

Distribution. Geographical. British Coasts, Belgium, Bay of Biscay (fide Hincks, No. 46), Mediterranean (Pruvot, No. 98), western side of North Sea (Pommerania). Not recorded at Heligoland (Hartlaub, No. 38), nor in Kattegat (Levinsen, No. 66).

Habitat. Commonly on a sandy bottom (Hincks). Schulze (No. 105) records it three times in the Pommerania dredgings on coarse ground, three times on sand and shell.

Antennularia ramosa (Chart IV.). Generally on the same grounds as $A$. antennina, but never so abundant. It was most numerous on Grounds VI. and XII. This species also fixes in the sand by a felt-work of root-fibres.

Distribution. British Coasts, South Africa (fide Hincks, No. 46), North Sea, 12-50 fathoms (Schulze, No. 105). In the Pommerania dredgings it was recorded on sand, on sand and shell, and on small stones.

Aglaophenia myriophyllum (Chart II.). Like Antennularia antennina and ramosa this species fixes itself in the sand by a felt-work of fine root-fibres. It confines itself much more entirely to this mode of attachment than Antennularia, and I have never found it growing on shells, stones, or polychaete tubes. Probably in consequence of this, A. myriophyllum is much more restricted in its distribution. On the Eddystone Grounds it was most common on the fine sand of Ground III., north-east and east of the rocks. It was constantly present on the adjoining sand (Ground IV.), and also on the coarse gravels mixed with fine sand or mud of Grounds XI., XII., and XIII. It was rare or absent on the remaining gravel and sand grounds in the neighbourhood of the Eddystone. On the fine sand of the inner and outer trawling grounds (I. and II.) it was only present in one haul, viz., haul 82.* It was absent on the Bolt Head Shell Gravel (XVII.), and was only once met with (in haul 29) on the Prawle Stony Ground (XVIII.).

Distribution. Geographical. British Coasts, Mediterranean, Gulf of St. Lawrence, Massachusetts Bay (fide Hincks, No. 46).

Depth. Chiefly from deep water (Hincks). 364 fathoms (Allman, Porcupine, No. 4).

Aglaophenia tubulifera. This species has only been taken twice; once fixed to a specimen of the Ascidian Polycarpa varians, in haul 55 (Ground X.), and once in haul 99 (Ground XVI., probably on a stone).

Distribution. Geographical. British Seas, South Africa (fide Hincks, No. 46).

Depth. In moderately deep water (Hincks).

Habitat. On sea-weeds, zoophytes, shells, etc.

* It will be noticed that this haul is exceptional also in the presence of Halecium halecinum and of fragments of Chaetopterus tubes. There is probably some coarse ground near it, the influence of which is being felt ( $c f$. p. 391). 
Plumularia pinnata. This species is very generally distributed, but less frequently met with on the fine sand grounds than on the gravels to the westward of the Eddystone. It is usually attached on these gravels to Chaetopterus tubes or to other hydroids. It was met with occasionally only on the Bolt Head Shell Gravel (XVII.) and on the Prawle Stony Ground (XVIII.).

Distribution. Geographical. Norway, Baltic, Kattegat (common), North Sea (rare at Heligoland), British Seas (Hartlaub, No. 38 ; Levinsen, No. 66 ; Hincks, No. 46), Mediterranean (?) (Carus, No. 14).

Depth. To 50 fathoms (Schulze, No 105, Pommerania).

Habitat. On shells, stones, sea-weeds, etc. (Hincks). This species seems to be less restricted by the nature of the material to which it readily fixes than some other hydroids.

Plumularia setacea. Less common on the Eddystone Grounds than $P$. pinnata. Especially scarce on fine sand grounds. Generally growing on other hydroids or on polychaete tubes. Taken several times on the Prawle Stony Ground (XVIII.).

Distribution. Geographical. Mediterranean, French Coast, British Seas. More plentiful at Heligoland than $P$. pinnata (fide Hartlaub, No. 38).

Depth. Littoral to 106 fathoms.

Habitat. On weed, zoophytes, rock, etc. (Hincks). On Ciona intestinalis (Sars, fide Hincks, No. 46), on Laminaria (Van. Ben. fide Hincks; Hartlaub), on Halichondria panicea (Bourne, No. 12).

Plumularia Catharina (Chart IV.). This is the most abundant species of Plumularia on the Eddystone Grounds, and it is present both on the fine sand grounds and on the gravels. On the fine sand grounds it is generally growing on other hydroids. On the gravels to the west of the Eddystone it is often very abundant on Chaetopterus tubes, generally in the form of the green variety described by Hincks, in which the erect stem is wanting. In this form it is quite a characteristic feature of the grounds where Chaetopterus abounds. In haul 90 (Ground V.), which is a fine sand ground, one colony only of this variety was taken, and it was growing on a piece of old leather. This is significant in view of the two facts that there were plenty of Pecten shells on this ground, to which one would at first sight have supposed that the species could attach itself, and that the species is abundant on other grounds in the immediate neighbourhood, fixed to the leathery tube of Chaetopterus.

Amongst the hydroids to which the ordinary form of the species has been found attached I have noted Hydrallmania falcata and Halecium halecinum. The species was never taken on the Bolt or Prawle Grounds.

Distribution. Geographical. British Coasts (Hincks, No. 46), Heligoland (Leuckart), between Cuba and Florida (Allman, No. 2), North Sea (Schulze, No. 105).

Depth. To 50 fathoms (Schulze).

Habitat. On shells, corallines, and especially the tests of Ascidians from deep water, shells of Pinna; stemless variety on Sertularella Gayi (Hincks). The Pommerania generally dredged the species on sandy ground. 
Plumularia frutescens. A very fine specimen in haul 10 (Ground XVI.), 5-6 inches high, growing on a Pecten maximus shell.

Distributron. Geographical. British Coasts, Algoa Bay (Krauss) [fide Hincks, No. 46]; Mediterranean (fide Carus, No. 14).

Depth. 5-34 fathoms (Schulze, No. 105, Pommerania).

Habitat. On stones and shells in deep water (Hincks). The Pommerania took the species twice, on shells and stones (34 fathoms) and on stony ground (5-10 fathoms).

\section{ActinOzoA.}

[Nomenclature:-Gosse, No. 30 ; or Haddon, No. 35.]

Alcyonium digitatum. The relative distribution of Alcyonium on the grounds examined is indicated in Chart I. Large colonies are abundant on the fine sand of the outer trawling ground (Ground II.), where they are generally fixed to Cardium echinatum shells, and also on the fine sand of Ground VI., south of the Eddystone, where they are attached to shells of various kinds. Large colonies are also abundant in the two deepest hauls on the Bolt Head Shell Gravel (hauls 27 and 28), and in the deeper hauls on the Prawle Stony Ground (hauls 4, 45, 66). On the other grounds near the Eddystone, and in the remaining hauls on the Bolt and Prawle Grounds, young colonies are frequently met with growing on living Pecten opercularis or on shells of different kinds, but they seldom, if ever, attain any considerable size.

It will be seen from the chart that all the grounds indicated above, upon which large colonies are taken, lie at depths of 34 and 35 fms., and are in fact the deepest portions of the area investigated. Other situations in which Alcyonium flourishes in the neighbourhood of Plymouth show that depth in itself can only indirectly influence its distribution, and that the species can also adapt itself to a variety of conditions of density, temperature, etc., without injury. For instance, very fine colonies are often found growing a few feet only below low-water mark, on the iron pillars supporting the Promenade Pier within the Sound. Colonies of moderate size are also found, exposed at low water, on the Eddystone rocks, attached to the overhanging ledge beneath the remains of the old lighthouse, on the more sheltered side of the rock.

Two of the most important factors which determine the local distribution of the species would appear to be (1) the presence of suitable objects upon which it can fix, and (2) the absence of movements of the water strong enough to break the colony from its base or to overturn the object to which it is attached. Since the species can fix to rocks, to stones, or to shells, the first of these conditions is fulfilled upon all the grounds examined in the present investigation, for suitable shells at least are everywhere found, so that the second becomes of the more 
practical importance. A large colony of Alcyonium when fully expanded offers a very considerable surface to any movement of the water, and when such a colony is attached to a shell of the size of Pecten opercularis or Cardium echinatum (which are the shells to which the small colonies are generally attached on the grounds under investigation) a very slight movement will be sufficient to overturn it. At a depth of 30 to 35 fms. we are probably approaching the limit at which wave action is seriously felt on the sea-bottom in this portion of the Channel.* This diminution of wave action certainly seems a reasonable explanation of the facts observed in the distribution of Alcyonium, namely, that at depths less than 34 or 35 fms., although small colonies growing on shells are common, large colonies are seldom found attached to such objects, but large colonies do exist, at any rate in sheltered situations, fixed to rocks or solid structures: at depths greater than 34 or $35 \mathrm{fms}$., on the other hand, large colonies are plentiful attached to shells.

Distribution. Geographical. Bergen and Hardanger Fjords (Norman fide Hickson, No. 45, p. 352); Kattegat (Levinsen, No. 66) ; North Sea (Schulze, No. 105; Hartlaub, No. 38). British Coasts; Brittany (Pruvot, No. 98); Bay of Biscay (Caudan, No. 61).

Depth. Low-water to 312-383 fathoms (Caudan).

Sarcodictyon catenata (Chart I.). The red variety is found growing, sometimes in considerable quantity, on old shells (chiefly old and worn shells of Lutraria elliptica and Pecten opercularis), and is generally most numerous on clean shell gravel, though by no means confined to such ground. It was most regularly taken on the shell gravel west of the Eddystone (Ground XVI. and some hauls of XIV.). On Ground VII., south of the Eddystone, it was present in one haul only (haul 100), where it was very abundant, growing on a flat piece of red Trias stone. It was occasionally taken on Grounds X., XIII., XV., and IV. (haul 39 only), in the neighbourhood of the Eddystone, and was not unfrequent on the Bolt Head Shell Gravel and on the Prawle Stony Ground.

The species was not taken on the fine sand grounds, I., II., III., V., VI., and VIII.

Distribution. Shetland (Norman, No. 90); west coast of Scotland and Irish Sea (Herdman, No. 40, p. 319, and No. 41, Vol. IX.); Brittany and Mediterranean (Pruvot, No. 98).

On nullipore ground, on sand and shell, on shell sand and small gravel, on shells, stones, and echinoderm spines, and on stones and mud. 10-40 fathoms (Herdman, No. 41).

Gorgonia verrucosa (red variety, G. Cavolini, v. Koch) was taken only in haul 3, on the Prawle Stony Ground (XVIII.). The trawl had here been over a patch of rocky ground, and came up very much torn. The species is always obtained on rocky ground in this neighbourhood.

\footnotetext{
* See page 375 , ante.
} 
Distribution. Gorgonia verrucosa occurs in the Mediterranean (v. Koch, No. 59; Pruvot, No. 98; Marion, No. 74), on the coast of Brittany (Pruvot), and on the southwest coast of England. Johnston (British Zoophytes, No. 56) records it, on the authority of Dr. Walker and of Sowerby, from Scotland. There is a British Museum specimen said to be collected by Forbes in the Shetlands (Cat. Brit. Rad. Animals, p. 56). Herdman and Leslie (No. 43) think that the species does not occur in the fresh condition in the Firth of Forth, although dead pieces have been occasionally seen there. Gorgonia verrucosa is therefore clearly a southern species which is seldom met with in any locality north of the English Channel.

In the Mediterranean von Koch seems to have always found this species of Gorgonia attached to stones.

Caryophyllia Smithii (Chart I.) is found attached to shells and to stones on the gravel grounds in the neighbourhood of the Eddystone, on the Bolt Head Shell Gravel, and on the Prawle Stony Ground. On the Eddystone Gravels it is very commonly attached to old Pecten maximus shells. The barnacle, Pyrgoma anglicum, is generally associated with it.

The species is entirely absent from the fine sand grounds.

Distribution. Geographical. Shetlands (abundant, Norman, No. 90); west of Scotland (Hoyle, No. 52); south-west of Ireland (Haddon, No. 34); Devon and Cornwall ; Brittany (Lacaze Duthier, No. 63); Azores (?) (Challenger, Moseley, No 89).

Leslie and Herdman (No. 43) do not record the species from the Firth of Forth. The Pommerania (Schulze, No. 105) found the dead skeleton only on the south coast of Norway, so that it appears to be absent from the North Sea. According to Lacaze Duthier (No. 63) the Mediterranean form, C. clavus, is a distinct species, and C. Smithii is not found in that sea.

Depth. 0-450 fathoms (Challenger, No. 89).

Habitat. On rocks, stones, and shells.

Epizoanthus incrustatus (Chart I.) was generally present on the outer trawling ground (II.), of which it is a characteristic species. It was taken twice (hauls 27 and 21) on the Bolt Head Shell Gravel. It was not present on the other grounds.

Distribution. Geographical. There is still considerable confusion as to the synonymy of this species. According to Haddon (No, 35) E. incrustatus (Düb. and Kor.) occurs on the east and west coasts of the North Atlantic, as far south as the English Channel and the Massachusetts coast. $E$. arenaceus (Delle Chiaje) he regards as a distinct species confined to the Mediterranean.

According to the same authority the species ranges in depth from shallow water to 906 fathoms.

Epizoanthus incrustatus occurs growing on shells, which are sometimes, but not always, inhabited by hermit crabs [Anapagurus laevis (Norman), Eupagurus excavatus (Haddon); Eupagurus meticulosus (Bourne, No. 11)].

Sagartia parasitica (Chart XII.) was always found associated with Eupagurus Bernhardus, but it is a curious fact that it was only taken on fine sand grounds (I., II., III., IV., V., and VII.), whilst the specimens of the hermit crab, which were not unfrequently taken on the gravels, were always without the anemone. I would not, however, suggest that this is at all a general rule.

Distribution. Geographical. A southern form, extending from the Mediterranean to the southern shores of the British Isles. Brittany (Pruvot, No. 98); southern part of 
North Sea (Pommerania, No. 105); Red Sea (Gosse, No. 30). The species is not recorded from the Irish Sea (Herdman), nor from the Shetland Isles (Norman).

Habitat. Generally on shells inhabited by Eupagurus Bernhardus.

Adamsia palliata (Table VI.) occurs on both sand and gravel grounds in the neighbourhood of the Eddystone. It has never been dredged on the Bolt Head or Prawle Grounds. The anemone was always found associated with Eupagurus Prideauxii.

Distribution. Geographical. A. palliata extends further north than $A$. parasitica. It is found in the Shetlands, on the west coast of Scotland, in the Irish Sea, south coast of Ireland (Gosse, No. 30); Brittany (Pruvot, No. 98); Mediterranean (Andres, No. 5).

Paraphellia expansa. Three or four specimens of this species have been obtained on the coarse gravel mixed with fine sand to the westward of the Eddystone (Grounds IX. and XI.). When taken, the anemones were not attached to anything, and appear to have been living buried in the sand.

Distribution. Paraphellia expansa was first obtained by Haddon (No. 35) on the south-west coast of Ireland, and has since been recorded by Herdman (No. 40) in the Irish Sea. Holt (No. 48) and Haddon (No. 34) record it at depths of 14-40 fathoms on the Irish coast.

Chondractinia digitata was obtained on two grounds only, namely, the outer trawling ground (II.) and the fine sand ground south of the Eddystone (VI.). These are the two deepest fine sand grounds examined. In all cases the anemone was growing on Cardium echinatum shells, fixed to the smooth inner side of the shell.

Distribution. Geographical. Finmark (fide Levinsen, No. 66); North Sea (Gosse, No. 30) ; Kattegat (Levinsen) ; Shetlands (Norman, No. 90) ; Cornish coast (Gosse); Bay of Biscay (Roule, No. 100, Caudan).

Depth. Deep water (Gosse). 98 fathoms (Roule).

Habitat. On shells of living Buccinum and Tritonium (Lütken). On Fusus islandicus, $F$. berniciensis, F. norvegicus, Buccinopsis Dalei, other common Fusi, and Buccinum undatum (Norman, No. 90). On Fusus antiquus in the Kattegat (Levinsen).

Corynactis viridis. Found in hauls 29 and 30 only on the Prawle Stony Ground (XVIII.), growing on large stones.

Distribution. Geographical. South-west coasts of England, of Scotland, and of Ireland (Gosse, No. 30) ; Shetlands (Norman, No. 90); Irish Sea (Herdman, No. 40); Brittany (Pruvot, No. 98); Mediterranean (fide Carus, No. 14).

Depth. Shore to 100 fathoms (Peach, fide Norman).

Habitat. On rocks and stones.

\section{ECHiNodermata.}

[Nomenclature:-F. Jeffrey Bell, Catalogue of British Echinoderms, British Museum.]

Holothuria nigra (Chart VI.) was taken in two hauls only (Nos. 10 and 99), both on the clean shell gravel immediately adjoining and west of the Eddystone rocks (Ground XVI.). Two or three specimens were dredged in each haul. 
The species is found in abundance, in a very similar situation, by the side of the ledge of rock running westward from the Plymouth Mewstone. Near this ledge the bottom-deposit is clean shell gravel, and $H$. nigra is generally obtained by working a dredge or trawl over this gravel, keeping parallel to the ledge and close to it. We have found no other locality in the neighbourhood where any but very occasional specimens are taken.

A possible explanation of these facts is that the animal is really a rock-haunting species, but that owing to the tenacity with which it is able to cling it escapes capture on rocky ground by any of the methods of collecting ordinarily used. If this be the case the specimens taken on the shell gravel, as described above, must be regarded as immigrants from the neighbouring rocks.

Habits. In confinement Holothuria nigra shows its climbing habit by spending a great deal of its time clinging to the sides of the tank in which it is placed.

The nature of its food is indicated by the fact that when captured the intestine is filled with fine sand and silt containing diatoms and organic remains.

The habit of this species of using the sticky thread secreted by the Cuvierian organs as a means of defence is well known.

Distribution. Geographical. Norman (No. 92) records the species from Plymouth, South Cornwall, south-west of Ireland, Naples ( $=$ H. Poli), Lesina (= H. catanensis), and Bay of Biscay. Bell (No. 7) records specimens from the west of Ireland, from Cornwall, and from Plymouth. Holt (No. 48, p. 280), Herdman (No. 40, Vol. V., p. 201), and Gamble (No. 26) all took $H$. nigra on the west coast of Ireland.

Depth. Herdman found the species between tide-marks, at Inishbofin, on the coast of Connemara, and Gamble in a similar situation at Valencia. The greatest recorded depth for the species is 30 fathoms (Bell, No. 7). In the Plymouth district it is taken in from 16 to 30 fathoms.

Bottom-deposit. Herdman's specimen was taken under a ledge of seaweed-covered rocks on the shore. Holt trawled specimens in 16 to 13 fathoms from a bottom described as sand and rock.

Astropecten irregularis (Chart. VIII.). The distribution of this species on the Eddystone to Start Grounds is shown in Chart VIII. The species in this neighbourhood is a typical representative of a fine sandy bottom. It was found in greatest abundance on the clean sand (Ground III.) 3-4 miles E.N.E. of the Eddystone, where the proportion of silt was small (see Table II., p. 525). It was also constantly taken, though in somewhat smaller numbers, on the outer and inner trawling grounds (Grounds I. and II.), where the sand is finer and contains a larger percentage of silt (see Table II.).

But the species is not entirely confined to the fine sand. As will be seen from the chart, it is present, though rare, on the gravel and brokenshell grounds around the Eddystone (IX., XI., XIII., XIV., and XVI.), one or two specimens being taken occasionally on each of these grounds, though by no means in every haul. On the sand immediately outside these gravels (IV., VI., and VII.) the species is also rare.

On the Bolt Shell Gravel (XVII.) and on the Prawle Stony Ground (XVIII.) Astropecten has never been taken.

NEW SERIES, - VOL. v. No. 4 . 
The presence of Astropecten on the gravel and broken-shell grounds around the Eddystone would appear to be a good illustration of the way in which the fauna of a particular ground may be influenced by the fauna of surrounding grounds ( $c f$. p. 388). It will be seen from the chart that these gravels occupy a comparatively small area, which is almost entirely surrounded by grounds on which the bottomdeposit is composed of fine sand, which is the true home of the species. The few specimens taken on the gravel would therefore appear to be rather of the nature of immigrants from these surrounding grounds.

The Polynoid Acholoe astericola is almost invariably found associated with this species, living in its ambulacral groove.

Habits. Astropecten irregularis is specially adapted both for progressing rapidly over the surface of the sand and for burrowing beneath it. The conical pointed tube-feet are the organs by means of which both these movements are accomplished. From observation of the species in the aquarium it appears that a great part of its life is spent beneath the surface of the sand. The process of burrowing, which is executed by the rapid movement of the tube-feet, has the appearance of a vertical sinking in the sand. The species remains at rest for long periods, with the central portion of its disc raised in a tall conical protuberance, the apex of which projects above the surface of the sand. The formation of a similar protuberance was described by Cuénot (No. 17 , p. 385 , and No. 18, p. 55) in the two Mediterranean species, Astropecten spinulosus and squamatus $[=A$. jonstoni (Delle Chiaje)]. Sladen (No. 106) describes such prominences on the disc of several species of Astropecten taken by the Challenger, and the same author has described a similar but much more elongated and non-retractile prominence as a family character of the Porcellanasteridae.

The food of Astropecten irregularis, as of other species of the genus, consists largely of bivalve and Gasteropod molluses, but small Echinoderms and Crustaceans are also eaten. I have myself found in the stomach of one specimen (haul 104) Echinocyamus pusillus, a fragment of Hippolyte sp. (?), and Natica nitida.

Forbes (No. 22) states that he has found Venus cassina in the stomach of this species, and that Ball found in one specimen nine Natica Alderi and a Turritella terebra ( $=T$. communis).

Distribution. Geographical. A. irregularis has a northern distribution. It occurs off the coast of Norway, in the Kattegat, on all British Coasts, and off the west coast of France (Ludwig, No. 70, p. 15, note 1). It does not occur in the Mediterranean, the statements that it is found there made by several authors resting on a record of Marion's, which Ludwig (l. c., p. 47 and p. 49, note) has shown to be based on a mistaken identification of the species $A$. pentacanthus, var. serratus. Studer (No. 108) states that $A$. irregularis was taken in the Gulf of Guinea in 59 fathoms. There is no other record, so far as I am aware, which confirms such a southerly extension of the species.

Depth. The species has a very considerable range of depth. Möbius and Bütschli (No. 
88) record it once from 6 fathoms (east of Skagen), and Petersen (No. 95) found it frequently in the Kattegat at depths of 10 fathoms and beyond. He found it once (sta. 226) at a depth of $6 \frac{1}{2}$ fathoms, and again at $8 \frac{1}{2}$ (sta. 274), both localities being in the same region as that from which Möbius and Bütschli's specimens were obtained. In the North Sea and more open seas around the British Islands the records (Bell, No. 7 ; Möbius and Buitschli, No. 88; Meissner u. Collin, No. 76) seem to indicate that the species does not flourish in such shallow water as this, there being few less than 20 fathoms, the reason being, in all probability, that the amount of wave-disturbance is too great. At depths below 20 fathoms it is abundant in many localities, up to 500 or even 1000 fathoms (Green and Bell, No. 33 ; Sladen, No. 106).

Bottom-deposit. Forbes (No. 22) states that he always took Astropecten irregularis on sandy ground. From the Pommerania expedition (No. 88) it is most frequently recorded from a sandy bottom, occasionally from muddy sand. In the Kattegat (Petersen, No. 95) it is generally distributed upon sand and muddy sand, but is not found on the mud. Meissner and Collin (No. 76) appear to have found it in the North Sea in greatest numbers upon mud and muddy sand, in smaller numbers upon sand. Haddon (No. 34) took the species in the south-west of Ireland, on mud in 47 fathoms, and on coarse sand in 35-40 fathoms. The haul of the trawl at 1000 fathoms off the south-west coast of Ireland, in which Astropecten irregularis ( fide Bell) was captured by Green, was made upon Globigerina-ooze, the trawl being full of this material when it arrived at the surface (No. 33). Koehler (No. 61, Caudan expedition) obtained a number of specimens from a haul on mud. From these records it is clear that the species is abundant only on fine ground, though the exact meaning attached to the terms sand and mud by the different authors is too uncertain to make it possible to define accurately the kinds of deposit in which it is most numerous.

Luidia Sarsi (Chart VII.). Three specimens of this species only have been taken, one on the fine sand of the outer trawling ground (Ground II., haul 24), and two on the fine gravel west of the Eddystone (Ground XIV., hauls 36 and 73).

Food. Petersen (No. 95) found Luidia Sarsi in the Kattegat feeding upon ophiurids, the remains of these animals being taken from their stomachs. Ludwig (No. 70) is unable to give any definite information as to the food of $L$. Sarsi, but has brought together the observations which are known on the food of the allied form $L$. ciliaris, from the stomach of which the following species have been taken:-Natica sp. (by Ball), Spatangus purpureus (by Couch), Ophioglypha and Echinocyamus pusillus (by Ludwig). Cuénot (No. 18) states that at Roscoff the star-fish attacks the bait on hooks set for dog-fish.

Distribution. Geographical. East Atlantic, from Norway (Throndhjemfjord) to Cape Verde Islands, and Mediterranean (vide Ludwig, No. 70).

Depth (vide Ludwig, p. 98). From 5 fathoms to 706 fathoms in the Mediterranean. On Atlantic Coasts the greatest recorded depth is 374 fathoms (Bell, No. 7, Porcupine Exp., Sta. 46).

Bottom-deposit. Ludwig (l.c.) states that the species prefers a muddy or sandy bottom, but that it is also found on coarser ground. L. ciliaris, on the other hand, is generally taken on hard ground ( $l$. c., p. 449). In the Kattegat Petersen (No. 95) found the species at a number of stations, generally on the mixed sand and mud deposits, occasionally on the mud. Koehler (No.61) took it in the Bay of Biscay (Caudan expedition) on gravel and sand, on gravel, and on mud.

Porania pulvillus (Chart VII.) was taken in considerable numbers (six or seven specimens in one haul of the otter-trawl) on the fine gravel to the west of the Eddystone (Ground XIV., hauls 36 and 73), one specimen was taken on the adjoining Ground X. (haul 42), and one on Ground IV. (haul 39).

Habits. No indication of a burrowing habit in this species has been observed, nor is it given to climbing when in confinement. 


\section{ON THE FAUNA AND BOTTOM-DEPOSITS NEAR THE 30-FM, LINE}

Distribution. Geographical. Off the coasts of Scandinavia and Britain (Sladen, No. 106), off the west coast of France (Perrier, No. 94, and Koehler, No. 61).

Porania pulvillus is not mentioned by Möbius and Butschli (No. 88), or by Meissner and Collin (No. 76) in the North Sea, nor by Petersen (No. 95) in the Kattegat, and it does not appear to exist in these localities, its place being taken by Hippasterias phrygiana. It does not occur in the Mediterranean (Ludwig, No. 70).

Depth. Herdman (No. 40, Vol. VIII., p. 19 ; Vol. IX., pp. 33 and 34) records specimens from 15 fathoms, 18 fathoms, and 20 fathoms, off the coast of the Isle of Man, and the species seems to be taken at all depths greater than this to 106 fathoms (Porcupine Expedition, Sladen, No. 106):

Bottom-deposit. Herdman gives the following records as to the nature of the bottomdeposit on which this species was taken off the coast of the Isle of Man :-On sandy mud, 33 fathoms (Brissopsis lyrifer, a typical mud-dwelling species was taken at the same time) [No. 40, Vol. VIII., p, 18]; on broken shell and small gravel, 15 fathoms, (Vol. VIII., p. 19); on "reamy" bottom [i.e., sand and mud (?)], 20 fathoms (Vol. IX., p. 33); on dead shell, sand and shell, and echinoderm spines, 18 fathoms (p. 34); on stones and mud, 19 fathoms (p. 37); on sand, gravel, and shells, 34 fathoms (Vol. X., p. 39). The Prince of Monaco (No. 94) took the species at four stations off the west coast of France on fine sand (74-98 fathoms). The distribution of Porania pulvillus appears therefore not to depend directly upon the nature of the bottom-deposit.

Palmipes placenta (Chart VII.). Palmipes was taken in largest numbers on Ground V. (haul 90). This is a fine sand ground (see Table II. and compare with samples 91 and 92 ) containing a considerable admixture of medium sand, together with some coarse sand and gravel. It has, on the other hand, a somewhat high percentage of silt $(7 \%)$. In the haul of the otter-trawl made on this ground some ten very, fine specimens were taken. The species was also very constantly taken on the sand ground south-west of the Eddystone (Ground VII.), though only one or two specimens were found in each haul of the dredge. It occurred in two hauls on the coarse gravel and sand north-west of the Eddystone (Ground XI., hauls 8 and 9), and single specimens were taken on the sand grounds VIII., III., and I. (haul 82).

Distribution. Geographical. Palmipes placenta has a distinctly southern distribution. It occurs all over the Mediterranean, on the west coast of France, in the English Channel, all around the Irish Coasts, and on the west coasts of England and Scotland as far north as the Shetlands. Rare on the east coast of Scotland and on the coast of Belgium. Entirely absent from other portions of the North Sea and from the Kattegat (vide Ludwig, No. 70 , p. 265).

Depth. In Mediterranean generally from 10-55 fathoms, occasionally 220 or 330 fathoms (vide Ludwig, p. 266). On British Coasts, from shallow water (seldom less than 10-15 fathoms) to 70 fathoms (Bourne, No. 11) and 100 fathoms (Sladen, No. 106).

Bottom-deposit. Ludwig ( $l$. c., p. 266) has brought together the records under this head. He shows that the species prefers hard ground to mud, and that it occurs both on gravel and on sand mixed with mud. Perrier (No. 94) gives a number of records of the species from fine sand in the Bay of Biscay.

Solaster papposus (Table VI.). This species was not generally abundant on any of the grounds. It was most numerous on Ground V. (haul 90), where the bottom was not very fine sand. There were also several specimens in haul 77 (Ground IV.). Single specimens were 
taken on many other grounds, both where the deposit was gravel and where it was fine sand.

Habits. Solaster papposus creeps on hard ground. Its food consists chiefly of molluses, which appear to be generally digested outside the body by the everted stomach. Forbes (No. 22, p. 114) states that it frequents oyster and scallop banks, and that Thompson found Cypraea and T'urbo crassicor in its stomach.

Distribution. Geographical. A northern species, found in the Aretic Ocean and on both sides of the North Atlantic, as far south as Massachusetts and the French Coasts (fide Bell, No. 7).

Depth. From shore (Forbes) to 640 fathoms (Bell).

Bottom-deposit. In the Baltic Möbius (No. 86, p. 103) records S. papposus from a bottom of stones and sand. In the North Sea Möbius and Bütschli (No. 88) record it from stony ground and from mud; Meissner and Collin (No. 76) from rocky ground and from sand and mud. In the Kattegat Petersen (No. 95) also found it on sand and mud and on rocky ground. Perrier (No. 94) records it off the coast of Newfoundland on pebbles (cailloux) at a depth of 82 fathoms. As in the case of many wandering echinoderms, the distribution of $S$. papposus does not appear to depend directly on the nature of the bottom-deposit, but rather on the presence of a suitable food-supply.

Henricia sanguinolenta (Chart VII.). The species is nowhere common on the grounds described in this report, generally not more than one, never more than two specimens having been found in one haul, and on each grôund it has only been taken in one or two hauls out of the total of those made. The only points which seem to be suggested by its distribution here are that it avoids both the fine sand and the coarse gravel, occurring generally on those grounds which are intermediate in texture. It may be important also that the deposit contains little silt on those grounds upon which the species has been found. It was taken once only on the Prawle Stony Ground.

Habits. H. sanguinolenta does not burrow. The fact that its tube-feet are provided with large suckers would at first sight appear to indicate that it is a climbing species and specially adapted to hard and rocky ground. This conclusion is supported by observation of its behaviour in aquaria, and Forbes (No. 22) states that on the east coast he generally found it among rocks at low-water. On the other hand, the species is also found living upon clay (sandy, blue, and Biloculina) and on blue mud, at depths down to 1350 fathoms (Sladen, No. 106, p. 541).

Distribution. Geographical. Both sides of the North Atlantic, Arctic Ocean, North Sea (Bell, No. 7; Sladen, No. 106). Not present in Mediterranean (Ludwig, No. 70).

Depth. Low-water (Forbes) to 1350 fathoms (Challenger, No. 106).

Bottom-deposit. Forbes (No. 22) and M'Intosh, among rocks at low-water. Möbius and Bütschli (No. 88, p. 148), on stony ground, on grey calcareous mud, on blue mud with some sand, and on coarse gravel. Möbius (No. 86), in the Baltic, 15-17 fathoms, stones, sand, and sea-weed. Petersen (No. 95), in Kattegat rare, on mixed deposits, chiefly in southern part. Herdman (No. 41, p. 319), Isle of Man, 15-25 fathoms, nullipore ground. Chadwick (No. 16), on the beach at Beaumaris, among roots of Laminaria. Holt (No. 48), on soft mud, corals, and weed, on coral and mud, on mud, sand, and stones, and on sand. Sladen (No. 106), on blue mud (1350 fathoms), on rock, on gravel and stones. Perrier (No. 94), on pebbles (cailloux) and on muddy sand. It appears, therefore, that the distribution of $H$. sanguinolenta does not depend directly, to any great degree, upon the nature of the bottom, but is probably influenced chiefly by the food-supply. As to the nature of this food-supply I am unable to give any information."

Asterias mubens (Chart VI.). This species has been taken on almost all the grounds, though it is very much more numerous on some than 
on others. Its distribution depends almost entirely upon the distribution of Pecten opercularis, as will be seen clearly from the tables. Owing to its gregarious habits $P$. opercularis is very much more abundant in some hauls made upon a particular ground than in others, and a study of the records of the individual hauls brings out the connection between the star-fish and the mollusc even more clearly than the summarised results given in Table VI.

Habits. A. rubens creeps on the surface of the sea-bottom, and appears to be almost independent of the nature of the bottom-deposit. It feeds very largely upon molluses (Forbes, No. 22, p. 87), and on the grounds described in this paper almost entirely upon Pecten opercularis. I have directly observed the remains of $P$. opercularis in the mouth of the star-fish. An account of the method adopted by this and allied species in opening various kinds of molluses has been given by Schiemenz (No. 104).

Distribution. Geographical. Bell (No. 7) gives "Eastern side of North Atlantic (Senegal to Finmark), Japanese Seas. Presence in Arctic Ocean uncertain, in Mediterranean very doubtful." Ludwig (No 70) does not include A. rubens amongst Mediterranean species. It is generally distributed in the Kattegat (Petersen) and Baltic (Möbius).

Depth. 0-110 fathoms (Bell); to 337 fathoms (Möbius and Bütschli, No. 88).

Bottom-deposit. The species is recorded on grounds of every texture, from rocky ground to mud.

Asterias glacialis (Chart VI.). The distribution of A. glacialis on the Eddystone grounds is almost exactly the same as that of $A$. rubens, and, like that species, it is always most abundant in those places where Pecten opercularis is found in numbers. It is noteworthy, however, that $A$. glacialis was never taken in the hauls south of Bolt Head nor on the Prawle Point Ground. The most easterly station was haul 60 (three miles south-west of Bolt Tail). The importance of this point will be apparent when the geographical distribution of the species is discussed.

Habits. A. glacialis is similar in its habits to $A$. rubens, and, like that species, lives largely upon molluses. It is perhaps rather more given to climbing than $A$. rubens. In addition to molluses, $A$. glacialis feeds upon almost any animal which it can capture, as well as upon dead fish, etc. (Ludwig, No. 70). Cuénot (No. 18) found a specimen feeding upon Portunus puber, and in the aquarium at Plymouth a specimen was found eating Polybius Henslowii.

Distribution. Geographical. The distribution of Asterias glacialis is discussed in detail by Ludwig (No. 70, p. 393). It is a southern species, common in the Mediterranean, and extending along the eastern shores of the Atlantic from Cape Verde Islands to Norway as far north as the coast of Finmark. Ludwig is doubtful as to whether the species really extends to Arctic Seas. A point of great interest in its distribution is its absence from the eastern portion of the English Channel, and from the southern and eastern part of the North Sea. "In the North Sea it is not known either on the east coast of England nor on the east coast of Scotland (Norman, 1865); it is also absent from the Belgian, Dutch, and German Coast, and the neighbouring islands. It is found, however, in the north-east part of the North Sea (Meissner and Collin) and between Scotland and Norway (Möbius and Bütschli). From there 
it extends into the Skager Rak as far as the Swedish Coast (Düben and Koren, M. Sars, Möbius), but is absent from the Kattegat and from the Baltic" (Ludwig, No. 70, p. 393). According to the same author the species is not found in the English Channel east of a line drawn from Plymouth to Cherbourg.

As was pointed out above, during the course of the present investigation $A$. glacialis was never once taken in the hauls south of Bolt Head nor in those made between Prawle and Start Points (in a total of 24 hauls), although it was quite common in the neighbourhood of the Eddystone. The most easterly station at which it was found was haul 60, three miles south-west of Bolt Tail. The depth was here 23-25 fathoms, and the bottom fine sand. Large specimens of Asterias glacialis are noted in my records as fairly plentiful, as were also Asterias rubens, Solaster papposus, and Echinus esculentus, and the haul was evidently made upon or close to a Pecten bed, as the presence of $P$. opercularis is recorded, and the shells of this species were taken in quantity.

It would almost seem, therefore, that there is a sharp line of demarcation in the distribution of Asterias glacialis in the neighbourhood of Bolt Head. Although it is true that Pecten opercularis was never abundant in any of the 24 hauls to the eastward of this line, it was present in several places, together with Asterias rubens, and there is no apparent reason why $A$. glacialis should not have been present as well. Indeed, one would rather have expected to find it on a ground such as the Prawle Stony Ground.*

Depth. 0 to 66 fathoms (Bell, No. 7) to 98 fathoms (Ludwig).

Bottom-deposit. A.glacialis is generally found on rocky and stony ground, but occurs also on sand. It is not, however, found upon mud (Ludwig).

Since on the grounds in the neighbourhood of the Eddystone both Asterias glacialis and Asterias rubens live side by side, under practically identical conditions, the following comparison of the general distribution of the two species, so far as at present known, is of interest:-

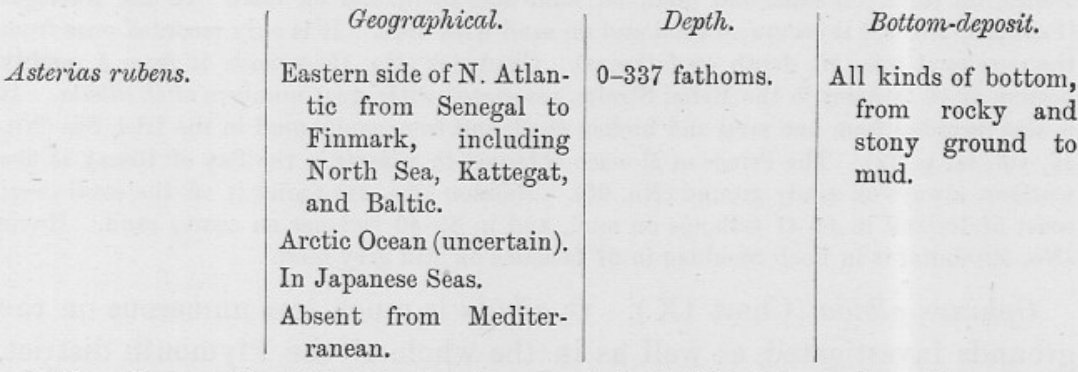

* My colleague, Mr. Holt, who has done a good deal of dredging and trawling in Start Bay and Teignmouth Bay, tells me that the most easterly record he has of A. glacialis is of a few specimens four miles S.W. by W. of Bolt Head. 


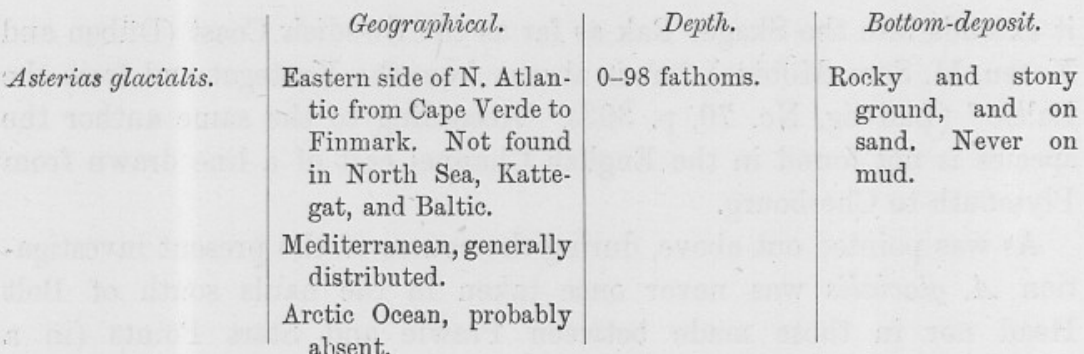

Ophiura ciliaris (Chart VIII.). This species has been taken on all the grounds, with the exception of the Prawle Stony Ground (XVIII.) and the fine gravel ground (XV.) It was taken in greatest numbers in the hauls on the gravel and sand, north-west and west of the Eddystone (Grounds IX., XI., XII.), and was moderately abundant also on the fine sand of the trawling ground (I. and II.). On the other grounds one or two specimens only were taken in a haul.

Habits. Ophiura ciliaris is not a burrowing species, but is capable of moving with considerable rapidity over the surface of the sand or gravel. Hence its distribution does not depend so directly upon the texture of the bottom-deposit, as in the case of burrowing forms, when once the deposit is sufficiently firm to prevent it sinking, but is probably determined by the presence of a suitable food-supply. The only record I have found of the food of this species is one by the naturalists of the Pommerania expedition. Möbius (No. 88) states that Prof. Metzger took from the stomach of a specimen dredged in 9 fathoms a Nephthys coeca, which was still alive. In a specimen which I examined from haul 93 I found the remains of a small crustacean.

Distribution. Geographical. Möbius and Bütschli (No. 88) give Norway, Kattegat, Great Britain, France, Mediterranean, and Madeira. A comparison of the distribution of this species with that of 0 . albida is made on p. 469, where the latter species is discussed.

Depth. Lyman (No. 71) gives the range 5 to 100 fathoms. In the Kattegat Petersen (No. 95) records it once (sta. 180) at $2 \frac{1}{2}$ fathoms, once (sta. 47) at 3 fathoms, once at 6 fathoms (sta. 132), and it is common in many parts at greater depths to 70 fathoms (sta. 58). Hoyle (No. 52) records the species from 100 fathoms, off St. Kilda, and Koehler (No. 60, Monaco dredgings) from 136 fathoms in the Bay of Biscay.

Bottom-deposit. Forbes (No. 22) states that this species does not confine itself so much to sandy ground as 0 . albida. Möbius and Bütschli (No. 88) record it in the North Sea most frequently from fine grey sand, once only from blue mud with some sand. Meissner and Collin (No. 76) in the southern part of the North Sea found it on coarse sand with fine stones, on sand, on sand and mud, on sand and shell, and on mud. In the Kattegat (Petersen, No. 95) it occurs on sand and on sand with mud. It is only recorded once from the pure mud (sta. 46, depth 49 fathoms). Chadwick (No. 15) records it from a muddy bottom at 10 fathoms in the Menai Straits, associated with great numbers of 0 . albida. It is also recorded from fine sand and broken shell, and from sandy mud in the Irish Sea (No. 40, vol. ix. p. 32). The Prince of Monaco obtained 0 . ciliaris in the Bay of Biscay at five stations, always on sandy ground (No. 60). Haddon (No. 34) found it off the south-west coast of Ireland in 44-47 fathoms on mud, and in 35-40 fathoms on coarse sand. Hoyle (No. 52) found it in Loch Sheildag in 67 fathoms on stiff grey mud.

Ophiura albida (Chart IX.). O. albida is much less numerous on the grounds investigated, as well as in the whole of the Plymouth district, than 0 . ciliaris, and its distribution is much more restricted. The only ground upon which it was found at all plentifully was the coarse gravel 
and fine sand ground (Ground IX.) to the west of the Eddystone. One or two specimens were generally taken on the fine gravel ground (XIV.) between the ground last mentioned and the Eddystone rocks, and several specimens were present on the gravel and mud ground (XIII.) south-east of the rocks. Single specimens were also met with on Grounds VIII., VI., and IV., as well as on the Bolt and Prawle Grounds. On the typical fine sand grounds (I., II., III., and V.) it was never met with, nor was it ever taken on the gravel and sand grounds north-west of the Eddystone (XI. and XII.), its absence being specially noteworthy in this case on account of the very close similarity in the composition of the bottom-deposits, as shown by the figures in Table II. (p. 525), of Ground XI.with that of Ground IX., upon which the species was numerous.

Habits. I know of no difference in the habits of this species and those of $O$. ciliaris, with the exception of the fact stated by Forbes (No. 22, p. 28), that it is less active in confinement than that species. Möbius (No. 88, p. 143) observed this species coil its arms around a living Nereis diversicolor and draw it into its mouth.

Distribution. Geographical. Möbius and Bütschli (No. 88) give Norway, Kattegat, W. Baltic, British Seas, Faröe, W. France, and Mediterranean. Bell (No. 7) adds to these the Arctic Ocean. Carus (No. 14) gives the Azores as one of the localities of the species, and the same locality is mentioned by Greeff (No. 32). On the whole, therefore, the range of 0 . albida appears to be about the same as that of 0 . ciliaris, with the exception of the northerly extension of the former to the Aretic Ocean. Forhes (No. 22) states that 0 . albida is more common than O. ciliaris in British Seas, and this certainly seems to be the case in the Irish Sea and in the North Sea. In the neighbourhood of Plymouth, as already explained, quite the reverse is true, 0 . albida being one of the rarer ophiurids, and very much restricted in distribution. Had 0 . albida been a distinctly northern form and $O$. ciliaris a southern one, it might have been supposed that the two species overlapped in this district, and that the southern form had almost but not completely replaced the northern one. The general distributions of the two species already given, however, makes such an explanation impossible. In this connection Forbes' statement, confirmed by Leslie and Herdman (No. 43), that $O$. ciliaris is common at the mouth of the Firth of Forth, whilst it becomes scarce and is replaced by 0 . albida further up, is of interest.

Depth. Lyman (No. 71) gives the range from 5-250 fathoms, showing that the species goes lower than 0 . ciliaris, a fact which may be correlated with its extension to the Arctic Ocean, and due to its adaptation to a lower temperature.

Bottom-deposit. Forbes (No. 22) states that 0 . albida frequents oyster-beds and sandy places, and that it is more confined to the sand than 0 . ciliaris. Möbius and Bütschli (No. 88) record it in the North Sea generally from mud or sand, occasionally from gravel. They state definitely that it is a mud-dweller (p. 146, note under Ophiocoma nigra). Meissner and Collin (No. 76) record it also generally from fine sand or mud, occasionally from coarser ground. In the Kattegat Petersen (No. 95) took the species frequently on sand and muddy sand, seldom on the pure mud. For the Irish Sea Chadwick (No. 15) records it as plentiful with 0 . ciliaris on a muddy bottom at 10 fathoms in the Menai Straits. He also mentions it off Port Erin on gravel and stones, and south of Isle of Man (10-20 fathoms) on nullipore and gravel. Haddon (No. 34) found it off south-west coast of Ireland, with 0 . ciliaris, in 44-47 fathoms on mud. Hoyle (No. 52), on the other hand, on the west coast of Scotland, took it in 34 fathoms with a number of smooth, rounded pebbles, Ebalia tuherosa - a species invariably found on a coarse ground-being present in the same haul. It would thus seem that O. albida is found upon almost, if not quite, as extensive a variety of bottom-deposits as 0 . ciliaris, and its peculiar distribution in the Plymouth district, where it is never taken on the fine sand and is confined to coarse ground, is the more difficult of explanation. 


\section{Ophiura affinis. One specimen only on the Bolt Head Shell Gravel} Ground (XVII., haul 28).

Habits. With reference to the animals of this species Hodge (No. 47) remarks upon

"their excessively lively movements and the wonderful pliability of the rays."

Distribution. Geographical. East and west coasts of North Atlantic and Mediterranean (vide Lyman, No. 71; Hoyle, No. 51 ; and Bell, No. 7).

Depth. 10-192 fathoms (Lyman and Bell), 267 and 294 fathoms (Möbius and Bütschli, No. 88).

Bottom-deposit. Möbius and Bütschli (Pommerania), on mud at 267 and-106 fathoms, on saud, on muddy sand, on sand and shell with small stones. Petersen (No. 95) found it in the Kattegat chiefly on sand and on sand and mud. Meissner and Collin (No. 76), on sand and mud, on coarse sand and stones, on mud and stones, on sand and shell, on mud, on fine dark sand, etc. It is evident that the species, like 0 . ciliaris and 0 . albida, lives on a great variety of grounds.

Ophiactis Balli (Chart IX.). This species is confined to the gravel and stony grounds. It is found hidden away in crevices between masses of Chaetopterus tubes, and in similar places. It is entirely absent from the sandy bottoms.

Habits. I can only confirm the statement of Norman (quoted by Bell, No. 7), viz., " it lives on hard ground, in deep water, and has a peculiar habit, delighting to nestle in hollows and crevices of stones, squeezing its disk and twisting its arms so as to conform to all the irregularities of the surface to which it attaches itself."

Distributios. Geographical. Scandinavian and British Coasts (Hoyle, No. 51), Bay of Biscay (Koehler, Nos. 60 and 61).

Depth. The deepest record is 240 fathoms (Hoyle, No. 50).

Bottom-deposit. Sand and gravel (Hoyle, No. 50), hard ground (Norman). Koehler records it from the Monaco dredgings from 50-100 fathoms on coarse ground, and once from the Caudan on coral (Lophohelia) from 200-270 fathoms.

Ophiocoma nigra (Chart VIII.). The only ground amongst those investigated where $O$. nigra is at all common is the Prawle Stony Ground (XVIII). On the gravel north-west of the Eddystone a few specimens were taken in one haul only (No. 47), on Ground IX. Occasional specimens were found on the gravels west of the Eddystone (IX., X., XII., XIV., XVI.) and on the Bolt Head Shell Gravel (Ground XVII.). The species is entirely absent from the fine sand grounds.

Habits. Möbius and Bütschli (No. 88, p. 146) state that 0 . nigra is fond of climbing up the vertical walls of a vessel in which it is living, from which they conclude that the species climbs rocks. A similar habit of the species has often been noticed in the tanks in the Plymouth Laboratory. The authors mentioned record 0 . nigra from five of the stations dredged by the Pommerania, at four of which it was abundant, and the ground is described as stony, at one it was searce, and the ground was white, granular sand rich in Foraminifera. As will be seen below, it is in such stony places that the species is generally numerous. It would seem, therefore, that its general habit is to climb about amongst stones. Petersen (No. 95, p. 47) states that the stomachs of his specimens were filled with mud (Bundmateriale), containing vegetable remains.

Distribution. Geographical. Ophiocoma nigra is a northern species. It is found on all British Coasts, in Norway, Kattegat (rare, Petersen, No. 95), and Barent's Sea (fide Hoyle, No. 51). I have seen no record of it from more southern waters.

Depth. The greatest depth recorded is 87 fathoms (Hoyle, No. 50, p. 714).

Bottom-deposit. Möbius and Bütschli record 0 . nigra from stony places. Petersen found the species at five stations only in the Kattegat on gravel and stony grounds, stones being recorded from four of the stations. Hoyle's record from 87 fathoms was from a bottom of 
sand and shells, and the species was associated with large numbers of Ophiopholis aculeata and Ophiothrix fragitis. Herdman (No. 40, vol, viii, pp. 17 and 20) records it in the Irish Sea, once from shell sand and small gravel and twice from stony ground. In the summer of 1896 I obtained this species in exceptionally large numbers off the mouth of Fowey Harbour, a number of large stones being dredged at the same time.

Ophiothrix fragilis. The distribution of this species on the grounds investigated is shown on Chart VIII. It occurs in by far the greatest numbers on the coarse gravel grounds north-west and west of the Eddystone. It has already been pointed out in the description of Ground $\mathrm{X}$. that 0 . fragilis occurs upon it in very large numbers, so much so that in some hauls (e.g., 89 and 95) the dredge came up half full of specimens of the species, to the almost entire exclusion of any other form. The species is also very abundant on the mixed gravel and fine sand deposits to the north-west and west of this ground (IX., XI., $\mathrm{XII}$.), as well as on the finer gravel between the latter grounds and the Eddystone (XIV.). It is also abundant on the mixed gravel and mud (XIII.) south-east of the Eddystone, a ground the fauna of which in many ways resembles that of the typical coarse gravel of Ground IX. On the fine sand grounds, on the other hand (I., II., III., etc.), Ophiothrix fragilis is very scarce, being generally only represented by a few small specimens, which cling about the roots of Cellaria or hydroids.

Habits. This is a creeping species which does not burrow. On the shore at low-water it is often found hidden under stones, and it is often seen elinging to stones, shells, and other solid objects brought up with the dredge. On those grounds where the species is found crowded together in large numbers, such as Ground X., the stomachs of the specimens examined have always been found to be filled with fine mud or silt, which, as explained on page 380 , is full of organic matter of various kinds. In shallower water the species has been observed to feed on compound ascidians and other similar organisms. On an old bottle recently dredged in the Cattewater, covered with a compound ascidian (Didemnid), there were a number of specimens of 0 . fragilis obviously feeding upon the ascidian. I do not think that actively moving animals, such as Polychaetes and Crustaceans, upon which $O_{I}$ hiura feeds (see above, pp. 468 and 469), are captured by 0 . fragilis.

Petersen (No. 95) found in stomachs of this species Diatoms, Peridinidae, Polychaete setae, vegetable cells, etc., together with fine sand grains, which evidently means that they were feeding on the fine silt, as they do in this neighbourhood. The Polychaete setae would probably be from the faeces of some other animal.

Distribution. Geographical. Norway to Mediterranean (Möbius and Bütschli, Lyman, Bell).

Depth. Bell (No. 7) records a specimen from 767 fathoms and Hoyle (No. 50) one from 516 fathoms. Hence the species, according to our present knowledge, has a somewhat wide range, viz., from the shore to 767 fathoms. It must, however, be noted that both Bell and Hoyle mention the difficulty of distinguishing this species from the deep-water form O. Luetkeni, Wyv. Thoms.

Botiom-deposit. Forbes (No. 22) mentions Ophiothrix fragilis as being fond of rocky places, but rare in sandy localities. Möbius and Buitschli (No. 88) found it on stony ground in the fjords of Norway, on sand and gravel, and on muddy sand in the North Sea. Meissner and Collin (No. 76) found it very plentiful on mud and sand, on mud, and on fine sand with sandy mud and stones. (The last ground would probably be similar to the Eddystone Ground X, on which the species is so plentiful.) In the Kattegat Petersen (No. 95) found $O$ fragilis chiefly on the mixed sand and mud. It was practically absent 
from the pure sand and from the pure mud. Chadwick (No. 15) records the species in great numbers off the southern shores of the Isle of Man in 10-20 fathoms on a bottom chiefly of nullipore and gravel.

Although these records are somewhat uncertain, owing to the difficulty of interpreting the exact meanings attached by the authors to the terms employed, they appear on the whole to indicate that when the species is found in very large numbers the bottom-deposit is a mixture of coarse gravel or sand with mud, similar to that upon which it is abundant in the neighbourhood of the Eddystone.

Echinus esculentus (Chart V.). Although present on most of the coarser grounds this species was nowhere very numerous, being represented by one or two specimens in a haul of the dredge and five or six in a haul of the otter-trawl. It was taken on all the gravel and shell grounds lying to the westward of the Eddystone, on Grounds IV. and XIII. to the eastward, and on the Bolt Head and Prawle Grounds. It is absent from all the fine sand grounds.

Habits. This is a wandering species, able to travel best upon hard ground. It is gregarious, large numbers being often found together. Its food is very various, and in confinement it will devour almost any dead animal matter. Specimens from moderate depths have the intestine filled with fine sand and silt, which is so common a form of food for Echinoderms. Professor MacBride informs me that in the estuary of the Clyde he has found the species on the shore, and that it there feeds upon red and brown sea-weeds. * In the Plymouth district it always occurs, so far as I am aware, at depths greater than 18 or 20 fathoms, where such sea-weeds do not grow. It is probable that the difference of distribution in the two districts is due to the very much greater effect of wave action in the neighbourhood of Plymouth than in the sheltered waters of the Clyde. Petersen (No. 95) found in the stomach of one specimen remains of Annelids, Barnacles, Polyzoa, Echinus spines, Ostracods, Algae and Hydroids, together with sand.

Distribution. Geographical. Eastern side of North Atlantic, North Sea, Mediterranean, Port Natal, and John Adam's Bank (Brazil) (fide Bell, No. 7).

Depth. From shore (Forbes) to 110 fathoms (Bell).

Botiom-deposit. Möbius and Bütschli (No. 88) record Echinus esculentus from stony and rocky ground (5-30 fathoms). Meissner and Collin (No. 76) give one record only, from a coarse bottom (Riffgrund). Petersen obtained it from rocky ground and from sand and mud. Chadwick (No. 15) records it from between tide-marks.

Echinus acutus (Chart V.). Like $E$. esculentus this species was never numerous, and its distribution coincided closely with that of the allied form. On the following grounds, however, upon which $E$. esculentus was taken, no specimens of $E$. acutus were obtained, viz., XVI., XII., XIII., and XVIII. On Ground VII. only one specimen was taken, in haul 54, and it was also represented in one haul only (34), on Ground IV. On Ground XVII. several specimens were obtained in haul 60 . It was entirely absent from the sand. On the whole the species was most numerous on deposits made up of a mixture of gravel and muddy sand.

Distribution. Geographical. Atlantic from Norway and Halifax to Ascension, North Sea, Mediterranean, off Kermadec Island (fide Agassiz, No. 1, and Bell, No. 7).

Depth. To 1350 fathoms [Agassiz]. There is no evidence that the species is ever found between tide-marks. From Koehler's records (Caudan, No. 61) it is clear that this is one of the commonest Echinoids at depths of from 80 to 400 fathoms in the Bay of Biscay.

* Compare M'Intosh, Marine Invertebrates and Fishes of St. Andrews, p. 95. 
Bottom-deposit. Möbius and Bütschli (No. 88) record E. acutus on stones and mud (0-50 fathoms) and on sand and shell (48-50 fathoms), and Agassiz (Challenger) on coral bottom (425 fathoms), on rock (630 fathoms), and on mud (1350 fathoms). Bell (No. 8) records the species from 55 fathoms, 110 fathoms, and 500 fathoms from Green's Trawling Cruise. 500 fathoms is apparently Green's Station VII. (No. 33), where the trawl brought up "one large boulder weighing about $100 \mathrm{lbs}$, and several smaller ones, subangular and resembling those of the Boulder Clay." Koehler gives a number of records from both Monaco (No. 60) and Caudan (No. 61) dredgings in the Bay of Biscay, the species being taken on rock and gravel, on coral, on sand and muddy sand, and several times on mud ( $80-400$ fathoms).

A question of some interest is raised by the distribution of the two species Echinus esculentus and Echinus acutus in the Plymouth district, which forms a good instance of a phenomenon very frequently met with. We here find two species of very similar structure, yet at the same time showing perfectly definite and constant difference in structure, living side by side upon the same grounds under what seem to be the same conditions, and having apparently exactly similar habits. The one species (in this case Echinus esculentus) is very numerous, whilst the other is much less so. The questions are often asked, how have these differences of structure been brought about and what purpose do they serve? Does the slight difference of structure in the less numerous species correspond to some slight difference of habit? or if this is not the case, how does it come to pass that the one species, being apparently less successfully adapted to the prevailing conditions than its more numerous competitor, survives at all?

In the present case it is, I think, possible to give a satisfactory answer to these questions, based on a consideration of the distribution of the two species.

From the records given above it is clear that Echinus esculentus is essentially a shallow-water species, which may be found on the shore or down to depths of 100 fathoms. It is most numerous in the laminarian and coralline zones. Echinus acutus, on the other hand, is essentially a deep-water species extending to a depth of over 1000 fathoms, and apparently most numerous from 50 to 500 fathoms. If we compare the essential differences of structure we see that each species is specially adapted to the conditions prevailing where it is most numerous, or as we may express it, the conditions prevailing at its centre of distribution. These differences of structure depend chiefly on the fact that whilst Echinus acutus is protected by a comparatively small number of very long spines, $E$. esculentus carries a large number of short and stout ones, the latter condition being obviously more advantageous in shallow water, where wave action is often violent, whilst it is not difficult to imagine that the former, viz., a few very long spines, is of greater value in deep water, where there is never any disturbance. Each species must be regarded, therefore, as being specially adapted to the conditions prevailing at its own centre of distribution, and it is at that centre ("centre of 
creation" of the older writers) that the characters of the species are kept true. In a case like the present, where the centres of distribution of two species of similar habit but slightly different structure are contiguous and the two areas quite continuous, there will be an intermediate region occupied by the two species in about equal numbers, whilst a few specimens of one species may extend quite to the centre of distribution of the other and be found living side by side with their now better adapted rivals. They survive because they are in continuous contact with, and are constantly recruited from, their own centre of distribution, where the characters of the species are kept true. Echinus acutus is found living in small numbers side by side with the numerous Echinus esculentus in the Plymouth district, because that district is sufficiently near to a deep-sea area where Echinus acutus is abundant, and to the conditions of which it is specially adapted. Should this communication in any way be cut off, the species would, in all probability, die out in the district.

Echinus miliaris. Chart V. Present upon practically all grounds. It appeared to be relatively most abundant on Grounds XVI. and XVII., both of which are clean shell gravel. On sandy grounds the species is generally found clinging to shells, hydroids, etc.

Habits. A wandering species inhabiting all kinds of grounds. On fine sand generally found attached to hydroids, shells, etc. It has a curious habit of attaching to itself, by means of its tube-feet, bits of shell, small stones, sea-weed, etc., in such a way that it becomes practically hidden by these objects. It lives on food of almost any kind, animal and vegetable, and does great damage on oyster-banks. A small specimen of this species was kept alive in the Laboratory in a shallow dish of sea-water for many months, being fed upon pieces of red seaweed, which it would eat in large quantities.

Distribution. Geographical. Northwards to Iceland and southwards to the Mediterranean, North Sea (fide Bell, No. 7), Kattegat (Petersen, No. 95), Baltic (Möbius, No. 86). Depth. From shore to 50 fathoms (Möbius and Bütschli, No. 88).

Bottom-deposit. Forbes (No. 22) records E. miliaris as common on oyster-beds and scallop-banks. Möbius and Bütschli found it on stony ground, on shelly ground, on sand, and on mud; Meissner and Collin (No. 76) generally on coarse ground, occasionally on sand and sandy mud.

It is evident that the nature of the bottom-deposit in itself is of no great importance to this species.

Echinocyamus pusillus. On account of the small size of Echinocyamus, much importance cannot be attached to the results of the dredgings as furnishing a knowledge of its distribution. It seems to be found most frequently upon coarse ground, especially upon clean shell gravel (e.g., Grounds XVI. and XVII.). 
Distuibution. Geographical. Both sides of North Atlantic, Norway, Iceland, Mediterranean, Azores, Florida, Caribbean Islands, North Brazil (A. Agassiz, No. 1).

Depth. Between tide-marks (Forbes, No. 22) to 805 fathoms (A. Agassiz, No. 1).

Bottom-deposit. Möbius and Bütschli (No. 88) record Echinocyamus pusillus from stony ground, from shell and sand, and from sand and mud. Meissner and Collin (No. 76) found it at a great number of stations, and apparently upon all kinds of bottom from rough ground to mud. Petersen (No. 95) in the Kattegat took it generally on sand, occasionally on the mixed ground (sand and mud). He found plant remains, diatoms, and foraminifera in the stomach. Herdman (No, 40) records it from nullipore bottom and from shell sand. It thus appears that the species can live under a great variety of conditions as regards the nature of the bottom-deposit.

Spatangus purpureus. Chart V. This, being a burrowing species, is much more restricted in its distribution by the texture of the bottomdeposit than those urchins, such as Echinus esculentus, which have a wandering habit. On the grounds examined during the present investigation it is almost entirely confined to clean shell gravel and fine clean gravel. It was most abundant and the specimens were largest on the shell gravel ground south of Bolt Head (Ground XVII.). Next to this ground it was most numerous on the clean shell gravel west of the Eddystone (Ground XVI.) and on the fine gravel just outside this (Ground XIV.), on both of which grounds it was frequently taken. Occasional specimens were found on Grounds VII., VIII., and X., the grounds immediately adjoining the two last-mentioned, and also on the Prawle Stony Ground (XVIII., hauls 45, 63, and 29). The species was never taken on the fine sand nor on the coarse gravel. The bivalve molluse, Montacuta substriata, was generally found attached to the spines of Spatangus.

Habits. The way in which Spatangus burrows by means of its short, flat bristles was described by Osler in 1826 (Phil. Trans. Roy. Soc., 1826, p. 347). The animal is able to sink almost vertically in the gravel in which it lives, and when half buried, at any rate, can progress forwards through the gravel, leaving a deep furrow behind it. The intestine is generally found to be filled with fine sand and silt ( $f f$. Möbius and Bütschli, Petersen).

Distribution. Geographical. East side of the Atlantic from the Azores to Iceland, North Sea, Mediterranean, Bermuda (fide Bell, No. 7).

Depth. $5-530$ fathoms (fide Bell).

Bottom-deposit. Forbes (No, 22) found S. purpureus abundant on scallop-banks off the Isle of Man, generally on the cleanest part of the bank amongst the seallops. Möbius and Bütschli (No. 88) record it on fine sand, on shell and small stones, on coarse gravel, and on sand; frequent only on the fine sand. Meissner and Collin (No. 76) give seven records, all from coarse ground, viz., on coarse sand and gravel, on shell and small stones, on shell, on stones and coarse sand, on shell and stones, and on coarse sand and stones. Petersen (No. 95) found it in the Kattegat at eight stations, at six of which the bottom-deposit was coarse sand or gravel. Once he records it from $15 \frac{1}{2}$ fathoms on sand with a little mud (sta. 437), and once from 70 fathoms on mud and fine sand (sta. 58). Haddon (No. 34) found it on coarse sand at the mouth of Bantry Bay. Bourne (No. 11) on fine sand in 200 fathoms. From the Liverpool district (No. 41, p. 137 ; No. 40, Vol. VIII., p. 20 ; Vol. IX., pp. 34 and 37) it is noted on muddy gravel near Beaumaris, on shells, stones, and echinoderm spines, on dead shells, shell sand, and echinoderm spines, and on "reamy" bottom. 
From the above records it. is clear that Spatangus purpureus lives most frequently in gravel and shell gravel, or in coarse sand, though it is not possible to judge from the great variety in the nomenclature used by the various authors exactly what texture it is intended to indicate. There seems no doubt, on the other hand, that the species may, under certain circumstances, be taken on fine sand and mud, and it will be important to notice in future what exactly are the conditions under which this occurs. Especially it should be discovered, if possible, whether such muddy or sandy grounds adjoin a coarse ground upon which the species is abundant.

Echinocardium cordatum. Chart V. Occasional specimens only of this species have been taken, which may to some extent be due to the fact that the trawl and not the dredge was generally used on fine sand grounds. As the species can bury deeply in the sand, it would not be likely to be captured in this way.

Single specimens were, however, found on the inner and outer fine sand trawling grounds (I. and II., hauls 51 and 104), on Ground VII., haul 76 (sand), and on Ground XV., haul 97 (fine gravel). All the specimens were of a dull white colour, and not bright yellow like those generally taken between tide-marks.

Habits. The habits of this species are similar to those of Spatangus purpureus, excepting that it burrows in fine sand, and judging from the situations in which it is found between tide-marks, burrows to greater depths.

Distribution. Geographical. Both sides of the Atlantic from Norway to Spain and S. Carolina to Bahia. North Sea, Mediterranean (fide Bell, No. 7).

Depth. $\quad 0-85$ fathoms (Bell, Agassiz, No. 1).

Bottom-deposit. Forbes states that the species abounds in sandy bays, and after storms great numbers are cast on shore. All the authors (Möbius and Bütschli, Meissner and Collin, Herdman, Petersen) record the species from fine sand and muddy sand only, to which it is rigidly confined.

The three heart urchins, Spatangus purpureus, Echinocardium cordatum, and Brissopsis lyrifera, form a good example of the fact that burrowing species are very much restricted by the texture of the deposit in which they dwell. Brissopsis lyrifera is as rigidly confined to mud as Echinocardium cordatum is to fine sand, whilst Spatangus purpureus is almost invariably found upon deposits of coarser texture. This was recognised by Forbes when he proposed for the three genera the English names Bank-Urchin, Mud-Urchin, and Sand-Urchin (No. 22, p. 183).

\section{Polychaeta.}

[Nomenclature:-Generally that of Saint-Joseph (Nos. 101 and 102).]

The Polychaetes of the earlier hauls were identified by Mr. T. V. Hodgson, those of the later ones by Professor Weldon. The responsi- 
bility for the statement that a species occurs upon a particular ground is in all cases my own. Owing to the fact that I was only acquainted with a few of the more common forms at the time when the dredgings were in progress, the information as to the relative abundance of each on the different grounds is less definite and reliable than that given for other groups. Several species are represented by one or two specimens only, but it is probable that if the material had been examined on board the boat at the time it was dredged by someone with a knowledge of them, other specimens would have been found. In all such cases it may, however, be taken for granted that the worm was nowhere abundant.

For geographical distribution I have relied largely on the lists given by Saint-Joseph (Nos. 102 and 103) and by Michaelsen (No. 79).

Polygordius $s p$. (Chart X.). An undetermined species of Polygordius was abundant on the clean shell gravel of the Bolt Head Ground (XVII.), where it formed a characteristic feature of the fauna. The same species was also found in much smaller numbers on the clean shell gravel immediately to the west of the Eddystone reef (XVI.).

Euphrosyne foliosa. Obtained once only on the fine gravel of Ground XIV., west of the Eddystone, in haul 85.

Distribution. Geographical. A southern species. Mediterranean, west of France, English Channel (Saint-Joseph, No. 102), Channel Islands to Shetland, especially on west of Great Britain and Ireland (M'Intosh, No. 84). Apparently not in the North Sea, where the northern species, $E$. borealis, Oerst., takes its place.

Depth. To 344 fathoms (Pola expedition, fide Saint-Joseph).

Aphrodite aculeata (Chart X.). This species was most abundant on the fine sand of Ground V., to the north of the Eddystone, where seven specimens were obtained in one haul of the otter-trawl. One or two specimens were taken on the neighbouring fine sand grounds III. and IV., but the species was never found elsewhere.

Habits. Aphrodite buries itself in the sand, but probably not to any considerable depth. " In confinement it is seen travelling rapidly at the surface of the sand, leaving deep furrows behind it.

Distribution. Geographical. Iceland, United States (Verrill), Faröe, Norway, British Coasts, Mediterranean, Red Sea (fide Michaelsen, No. 79, and Saint-Joseph, No. 102).

Depth. Shore (Saint-Joseph) to 530 fathoms (Knight Errant), 257 fathoms and 690 fathoms (Porcupine, M'Intosh, No. 82).

Bottom-deposit. All the authors record the species from sandy or muddy ground, never from gravel or coarse ground (Möbius, No. 87; Hansen, No. 36; Michaelsen, No. 79; Haddon, No. 34 ; Hornell, No. 49).

Hermione hystrix. Single specimens were obtained on the coarse gravel of Grounds IX. and X., in hauls 93 and 42 only. The species in the Plymouth district is generally met with on coarse grounds, and has never been found to be abundant.

NEW SERIES.-VOL. v. No. 4. 


\section{ON THE FAUNA AND BOTTOM-DEPOSITS NEAR THE 30-FM. LINE}

Distribution. Geographical. Pas-de-Calais, North Sea, Channel, Atlantic, Mediterranean (Saint-Joseph, No. 102). The Challenger obtained two small specimens at Cape Verde Islands (M'Intosh, No. 85) Irish Sea (Hornell, No. 49). Hermione hystrix is a distinctly southern species. Claparède and Marion and Bobretzky (No. 73) state that it is extremely abundant in the Mediterranean. According to Malmgren (No. 72) and Michaelsen (No. 79), the corresponding northern species appears to be Laetmonice filicornis, Kinberg.

Depth. Occasionally on the shore under stones in the Mediterranean (Marion and Bobretzky) ; 40-80 fathoms (Porcupine, off Algiers, M'Intosh, No. 82).

Bottom-deposit. Hornell states that in the Irish Sea this species is found on shell débris, gravel, etc., never on purely sandy or muddy deposits, which agrees with the distribution found in the Plymouth district. Marion and Bobretzky say that in the Gulf of Marseilles it is especially abundant on zostera beds.

Lepidonotus squamatus (Table VI.) is found occasionally upon grounds of all kinds, but is more numerous on the gravels to the westward of the Eddystone than elsewhere. On Ground IX. (haul 93) it was very abundant.

Distribution. A northern species. Coast of Virginia (Verrill), Iceland, Faröe, Norway, England, north-west France (fide Michaelsen, No. 79). The Challenger dredged one small specimen at the Azores in 450 fathoms, on a bottom of volcanic mud, which M'Intosh (No. 85 ) refers to this species. The Porcupine (No. 82) obtained Lepidonotus squamatus on a stony and muddy bottom at 30-40 fathoms off Dingle Bay. Hornell (No. 49) found it most abundant in the Irish Sea in 18 to 20 fathoms.

Eunoe nodosa (Table VI.). One specimen taken in haul 45 on the Prawle Stony Ground (XVIII.) was identified by Prof. Weldon.

Distribution. East of North America, Greenland, Iceland, Spitzbergen, Nova Zembla, Kara Sea, Siberia, Norway, Shetland, England, north-west of France, English Channel ( fide Michaelsen, No. 79).

Lagisca propinqua (Table VI.) is an abundant species, taken both on the fine sand and on the gravel grounds.

Distribution. L. propinqua has a wide range both in its geographical and bathymetric distribution. It is found on the United States Coasts, Faröe, Shetland, south-east of Scotland, and at Madeira (fide Michaelsen, No. 79). It was obtained by the Knight Errant in the Faröe Channel, at a depth of 515 fathoms, on a bottom of ooze (No. 85). The Caudan took it at three stations in the Bay of Biscay, on coral and mud and on mud, at depths from 355 to 930 fathoms (Roule, No. 101). Hornell found it constant and abundant in the Liverpool district, beneath stones and in rock cavities from mid-tide to 57 fathoms (No. 49).

Lagisca rarispina (Table VI.) was identified by Prof. Weldon in haul 92 on the fine sand Ground I., and in haul 70 on the fine sand Ground VII.

Distribution. An Arctic species. East of North America, Greenland, Iceland, Siberia, Nova Zembla, Kara Sea, North-West Norway, North of England ( fide Michaelsen, No. 79). In the North Sea it was taken on bottoms of mud and muddy sand, at depths from 20-24 fathoms, being sometimes abundant (Michaelsen, No. 79). The Norwegian North Atlantic expedition obtained it at a depth of 160 fathoms, on a bottom of grey clay (Hansen, No. 36$)$.

Harmithoe imbricata (Table VI.). Occasional specimens on the fine sand Grounds III. and VII., and on the clean shell gravel of Ground XVI. 
Distribution. Geographical. East of North America, Greenland, Iceland, Faröe, Spitzbergen, Nova Zembla, Kara Sea, Siberia, South Japan, Norway, Scotland, England, Ireland, north and west of France, Spain [fide Michaelsen, No. 79].

Depth and Bottom-deposit. This is a common species between tide-marks, where it is found under stones [Shetlands, Irish Sea, North Sea, Dinard, Plymouth]. The Valorous expedition [No 83] obtained it in 20 fathoms (shell sand), 60 fathoms (sand and shell), and 80 fathoms off the coast of Greenland ; the Porcupine (No. 82) at 60-160 fathoms, east of Cape Gatte; the Norwegian North Atlantic expedition [Hansen, No. 36] at depths of from 35 to 127 fathoms (clay); and the Caudan [Roule, 101] in the Bay of Biscay at 98 fathoms on gravel and sand, and at 219 fathoms on mud.

Evarne impar (Table VI.). Specimens were obtained on the fine sand of Grounds I. and VII., on the fine gravel of Ground XIV., to the west of the Eddystone, and on the Prawle Stony Ground. The species was nowhere numerous.

Distribution. Davis Straits (M'Intosh, Valorous, No. 83), Iceland, Shetland, North Norway, British Coasts, North France (fide Michaelsen). Outside Gibraltar (358 fathoms, M'Intosh, Porcupine). Shore (Saint-Joseph, No. 102, and Hornell, No. 49) to 567 fathoms (Porcupine, No. 82).

Polynoe scolopendrina. Mr. Hodgson has identified a single specimen of this species in haul 54 on the fine sand of Ground VII.

Distribution. M'Intosh (No. 84) states that the species occurs from Shetland to the Channel Islands, generally in tubes of Terebella nebulosa, and that it is abundant on the shore in the Hebrides (No. 81). Saint-Joseph (No. 102) found it on the shore and also in deeper water at Dinard. Irish Sea (Hornell). Adriatic, Trieste, Egypt (fide Carus, No. 14).

Halosydna gelatinosa. A single specimen on the typical coarse gravel, Ground IX. (haul 93). The species is not unfrequently taken in the Plymouth district in shallower water. It occurs on the shore at low-water.

Distribution. West Norway, British Coasts, North-West France, west of Morocco (fide Michaelsen, No. 79). Hornell (No. 49) records it from the shore at Puffin Island (Irish Sea).

Hermadion assimile. A single specimen in haul 92 on the fine sand of the inner trawling ground (Ground I.).

Distribution. M'Intosh (No. 84) records the species from St. Andrews and from the Porcupine dredgings off the west of Ireland, south of England, and Spanish coast. Hornell (No. 49) took it in the Irish Sea in depths of 11 and 21 fathoms amongst the spines of Echinus esculentus.

Acholoe astericola is by no means uncommon in the ambulacral groove of Astropecten irregularis. Its occurrence is incompletely recorded in Table VI.

Distribution. Hornell (No. 49) gives the distribution from the Mediterranean to Galway. Marenzeller found it in the Mediterranean on Astropecten aurantiacus, on $A$. bispinosus, $A$. platyacanthus, and $A$. pentacanthus.

Hyalinoecia tubicola. Chart $\mathrm{X}$. This species is abundant on the coarse gravel mixed with sand and mud in the neighbourhood of the Eddystone, where it forms one of the typical and characteristic features of the fauna. It is specially numerous on Ground IX., which exhibits 
the coarse gravel fauna in its purest form, and is still plentiful on the gravel of the adjoining Ground XI. It was also taken in several hauls on the Ophiothrix fragilis Ground (X.). On the coarse gravel and mud of Ground XIII., south-west of the Eddystone, the fauna of which resembles in most of its features that of Ground IX., Hyalinoecia was also abundant. A few specimens were taken on the fine sand grounds adjoining the coarse Eddystone Grounds (III., IV., VII., and VIII.). On the remaining fine sand grounds and on the fine gravels and clean shell gravels the species was entirely absent, nor was it taken on the Prawle Stony Ground.

Habits. What are the habits of Hyalinoecia tubicola in the natural state I am unable to say. In confinement it does not burrow, but is capable of somewhat rapid locomotion over the surface of a gravel bottom. The movement is effected by protruding the head and anterior portion of the body from the tube for a distance of about an inch in specimens of the ordinary size, holding to the gravel by the appendages of the most anterior segments and drawing the tube along, the body being bent sharply at right angles at the point where it emerges from the tube. The head is then thrown forward, attached again to the gravel, and the previous movement repeated.

Distribution. Geographical. North and West Norway, Kattegat, North Sea, British Isles, English Channel, west of France, Mediterranean, Madeira ( fide Saint-Joseph, No. 102, and Michaelsen, No. 79). The Challenger obtained Hyalinoecia tubicola at the Azores (50-90 fathoms), and one small, dried specimen from the south of Japan (565 fathoms) is also referred to this species (M'Intosh, No. 85).

Bottom-deposit and Depth. In the Irish Sea the species is taken on pure mud at depths of from 40 to 80 fathoms, where it constitutes one of the characteristic features of the fauna (Herdman, No. 40, Vol. VIII., p. 18; Vol. IX., p. 53). In the Skagerack and Kattegat it also occurs on deposits of pure mud (Levinsen, No. 66). Off the south-west coast of Ireland, Haddon, on the other hand, found it on coarse sand (35-40 fathoms) and on sand (110 fathoms) (Haddon, No. 34). The Challenger specimens off the Azores were on volcanic mud (50-90 fathoms), and the one small specimen off the south of Japan was on green mud ( 565 fathoms). The Caudan found $H$. tubicola abundant at 98 fathoms at two stations on gravel and sand, and also at 137 fathoms at one station on mud.

From the above records, combined with my own from the Eddystone Grounds, it would seem that Hyalinoecia tubicola is equally at home on pure mud and on gravels mixed with sand and mud. It is probable, however, that further knowledge of its habits and distribution will show that its real centre of distribution is on deposits of one only of these kinds, and that those occurring in deposits of the other kind must be regarded as outlying individuals, which have extended to grounds where the conditions are still such that they can exist, though not such as those to which they are most perfectly adapted.

Lumbriconereis. A large and a small species, which have not been certainly identified, were occasionally taken (see Table VI., p. 531). 
Nereis fucata. This species is very frequently met with in Buccinum undatum shells inhabited by Eupagurus Bernhardus. The actual number of records is not great, as in only a few cases in the hauls made during this particular investigation were the shells opened to seek the worm.

Distribution. North America, Great Britain, France (fide Michaelsen, No. 79). Generally in Buccinum or Fusus shells inhabited by Eupagurus Bernhardus (Michaelsen, Saint-Joseph, Hornell). Hornell (No. 49) found the worm in ninety per cent. of the shells inhabited by $E$. Bernhardus. He also sometimes took it free.

Nereis procera. Not uncommon on the fine sand grounds, especially on Grounds II., III., VI., and VII. It also was taken on the coarse gravel and fine sand north-west of the Eddystone (Ground XI.) and on the Bolt Head Shell Gravel (Ground XVII.).

Distribution. Gulf of Georgia (Ehlers), Madeira (Langerhans), Dinard (Saint-Joseph).

Typosyllis alternosetosa. Several specimens identified by Professor Weldon in hauls 101 and 102 on the fine sand of Ground VI., south of the Eddystone.

Distribution. This species has been recorded only from the north coast of France by Saint-Joseph (No. 102).

Ehlersia cornuta. One specimen in haul 87 on Ground XVI.

Distribution. Norway, Spitzbergen, Atlantic, Madeira, Mediterranean [fide Carus, No. 14]. VII.

Eulalia viridis. Identified by Mr. Hodgson in haul 54 on Ground

Distribution. Behring Straits, North Sea, Channel, Atlantic, Mediterranean (fide Saint-Joseph, No. 102). Kattegat (Levinsen). Michaelsen (No. 79) took it in the North Sea on both coarse and fine grounds (1-44 fathoms). M'Intosh (No. 81) records it from the shore at Shetland, and the Pommerania obtained it amongst stones and algae in 4 fathoms (Möbius, No. 87). Common on shore at Plymouth.

Amblyosyllis spectabilis. In haul 27 only on the Bolt Head Shell Gravel (Ground XVII.).

Distribution. English Channel.

Polydora caeca. Several specimens in haul 101 on the fine sand south of the Eddystone (Ground VI.).

Distribution. Northern Oceans, Mediterranean? [ fide Saint-Joseph].

Nephthys Hombergii. In haul 91 on the fine sand of Ground III.

Distribution. Nova Zembla, Kara Sea, Norway, Faröe, England, France, Madeira, Mediterranean [fide Michaelsen, No. 79].

Depth and Bottom-deposit. Saint-Joseph (No. 102) obtained this species at Dinard on the shore only ; Hornell (No. 49) in the Irish Sea, common from the shore to 22 fathoms. The Norwegian North Atlantic expedition took it at 142, 148, and 263 fathoms on mud (clay) (Hansen, No. 36), and the Caudan in the Bay of Biscay on mud at 160 to 220 fathoms and at 98 fathoms (Roule, No. 101).

Glycera convoluta was obtained on the clean shell gravel immediately to the west of the Eddystone rocks (Ground XVI.), where it was a characteristic feature of the fauna. Specimens of Glycera, almost 
certainly referable to this species, were also taken on the Bolt Head Shell Gravel (XVII).

Distribution. Channel, Atlantic, Mediterranean (fide Saint-Joseph, No. 102). The Caudan dredged one specimen in the Bay of Biscay on mud in 98 fathoms (Roule, No. 101). Saint-Joseph states that it occurs on all French Coasts on muddy sand.

Chatopterus variopedatus. (Following Joyeux-Laffuie, No. 65, and Saint-Joseph, one species of Chaetopterus only is recognised as inhabiting European Seas.) Chart X. The most striking feature of the coarse gravel grounds in the neighbourhood of the Eddystone is the abundance of Chactopterus, and the presence of large masses of its leathery tubes has a great influence on the general fauna of the grounds. The species is most abundant on the coarse gravel and sand of Grounds IX. and XI. and on the fine gravel of Ground XIV. to the westward of the Eddystone, and on the gravel and mud of Ground XIII. to the south-east. From these centres of distribution it extends in diminishing numbers on to the surrounding grounds. On the fine sand of Ground VII., where shells are numerous, Chaetopterus is still moderately plentiful, and a good many were even present on the fine sand of Ground VI., still further from the centre of distribution. On other fine sand grounds, as well as on the Bolt Head Shell Gravel and the Prawle Stony Ground, the species is either absent or represented only by one or two stray tubes.

Habits. The tubes of Chaetopterus are generally attached in the first instance to shells, but they soon attain a size very much greater than that of the shell to which they originally fixed, and they then attach themselves to the gravel itself or to any solid object with which they come in contact. In this way one often finds large clusters of the tubes joined together into masses, with two or three shells fixed firmly to the mass. The fauna which depends directly upon the presence of these masses of tubes has already been described (see p. 414). In addition to the species there mentioned the Polyzoan Hypophorella expansa, Ehlers, has been found in Chactopterus tubes taken in the neighbourhood of the Eddystone (Harmer, No. 37), and was probably present in a large proportion of the specimens captured (compare also Joyeux-Laffuie, No. 64). The habits of Chaetopterus are well described by JoyeuxLaffuie (No. 65). The animal obtains its food by drawing a current of water through its tube and extracting the floating organisms.

Distribution. Geographical. Northern Seas, Channel, Atlantic, Mediterranean [fide Saint-Joseph, No. 102].

Depth and Bottom-deposit. Joyeux-Laffuie (No. 65) states that on the French coasts Chactopterus is found in shallow water and even occasionally between tide-marks in sheltered situations, where the action of the waves is slight, but that on exposed coasts it occurs only in deeper water. It is often washed ashore in very large numbers after heavy gales. Saint-Joseph (No. 102) found it at Dinard on the shore only. In the Irish Sea it is recorded from the shore at low-water at Beaumaris (Williams, fide Hornell, No. 49), on a 
"reamy" bottom (sand and mud), in 30 fathoms; on dead shells and sand, 22 and 25 fathoms; on stones and mud, 19 fathoms (Herdman, No. 40, Vols. VIII. and IX.).

Pectinaria auricoma (Table VI.). Single specimens of a Pectinaria with a curved tube, identified by Mr. Hodgson as $P$. auricoma, are not unfrequently met with. They have occurred on Grounds VII. and VIII. (fine sand with shells) and X. and XII. (coarse gravel and sand) in the neighbourhood of the Eddystone, on the Bolt Head Shell Gravel (Ground XVII.), and the Prawle Stony Ground (XVIII.).

Distribution. Geographical. North and West Norway, North Sea, British and Irish Coasts, Mediterranean [ fide Michaelsen].

Depth and Bottom-deposit. M'Intosh [No. 81] found Pectinaria auricoma in the Shetlands at depths from 50-100 fathoms; Haddon [No. 34] off the south-west of Ireland on coarse sand in 35-40 fathoms; Möbius [No. 87] in the Pommerania dredgings generally on sandy mud, occasionally on coarse ground from 12 fathoms to 217 fathoms. In the North Sea also Michaelsen [No. 79] obtained it generally on mud and fine sand, occasionally on coarser ground. In the Kattegat Levinsen [No. 66] records $P$. auricoma from $12 \frac{1}{2}$ to 17 fathoms on mixed deposits (sand or gravel with mud). In the Liverpool district Hornell [No. 49] found $P$. auricoma rarely in 20-22 fathoms, whilst $P$. belgica was common from low-water to 21 fathoms.

Polymnia nebulosa (Table VI.) occurred in small numbers on the gravel grounds around the Eddystone (IX., XIII., and XIV.), and on the sand ground (VII.) immediately to the south of these.

Distribution. West Norway, British Coasts, West France, and Mediterranean (fide Michaelsen, No. 79).

Nicolea venustula (Table VI.). Occasional specimens almost entirely confined to fine sand grounds.

Distribution. Greenland, Iceland, Faröe, Spitzbergen, Nova Zembla, Siberia, Norway, British Coasts, French Coasts, Mediterranean, Red Sea [fide Michaelsen, No. 79, and Saint-Joseph, No. 102].

Depth, etc. 2-15 fathoms (Saint-Joseph); 20-22 fathoms (Hornell). On zostera (Michaelsen); on Rytiphlaea pinastroides (Saint-Joseph).

Thelepus sp. (Table VI.). A species of Thelepus is very common on the grounds investigated. Relying on the character of the uncini it would seem to be T. setosus, Saint-Joseph. The differences between this species and the common $T$. cincinnatus are, however, so slight that there is probably much confusion between the two in the literature. In the account of the distribution I therefore give that for each of these species.

On the Eddystone Grounds Thelepus is very common on all the fine sand and also on the coarse gravel to the west of the rocks. On the coarse gravel south-east of the Eddystone (Ground XIII.) it was not taken, and only an occasional specimen on the fine gravel of Ground XIV. was seen. It was not present on the clean shell gravel (XVI.), nor on the Bolt or Prawle Grounds.

Distribution. T. setosus, Saint-Joseph, has been recorded only on the north coast of France (Saint-Joseph, No. 102) at depths of from 2 to 15 fathoms. T. cincinnatus, Fabr. North America, Greenland, Iceland, Faröe, Spizbergen, Jan Mayen, Nova Zembla, 
Kara Sea, Siberia, North and West Norway, North Sea, British Coasts, French Coasts, Mediterranean [fide Michaelsen and Saint-Joseph].

Depth and Bottom-deposit ( $T$. cincinnatus). The Pommerania dredged the species generally on fine sand, sometimes on coarse grounds from 10 to 49 fathoms (Möbius, No. 87) In the Shetlands. M'Intosh (No. 81) obtained it from 50 to 120 fathoms, and the Knight Errant found it at 540 fathoms (M'Intosh, No. 85). Hornell (No. 49) records it in the Irish Sea from shore to 22 fathoms, becoming more abundant in the deeper water. The Norwegian North Atlantic expedition obtained it at seven stations from 35 fathoms to 658 fathoms, generally on a bottom of clay (Hansen, No. 36). The Caudan found it numerous at three stations in the Bay of Biscay, twice at 98 fathoms on gravel and sand, and once at 219 fathoms on mud (Roule, No. 101).

Amphitrite gracilis. An occasional specimen on Grounds VII. (fine sand) and XVII. (Bolt Head Shell Gravel).

Distribution. North America, Greenland, Kara Sea, British Coasts (fide Michaelsen, No. 79). Saint-Joseph found it at Dinard on the shore only, living in mud between stones, and not forming a tube.

Polycirrus aurantiacus. Two specimens on the muddy gravel ground (XIII.) south-east of the Eddystone. The species is common in Plymouth Sound (Millbay Channel) and in the estuary of the Yealm.

Distribution. English Channel, west of France, Mediterranean (Saint-Joseph, No. 102). At Dinard in 2-15 fathoms. M'Intosh records it from the Shetlands in $70-80$ fathoms. The Pola dredged it in 220 fathoms (fide Saint-Joseph).

Sabellaria spinulosa. Forming very hard, sandy tubes on shells, etc. Though the records are not numerous the species was common on all grounds where dead shells were numerous.

Distributron. North Sea, Channel, Atlantic (Saint-Joseph). In North Sea, 0-40 fathoms (Michaelsen).

Sabella (pavonina?). Specimens never reaching a length of more than three or four inches, but probably belonging to this species, were common, generally attached to the base of hydroids on both the fine sand and coarse gravel grounds in the neighbourhood of the Eddystone. They were especially abundant on the fine sand, usually associated with Sertularella Gayi.

Distribution. Geographical. North America, Greenland, North-West and West Norway, British Coasts, North-West France, and west of English Channel (fide Michaelsen).

Depth and Bottom-deposit. The Pommerania obtained Sabella pavonina from 16 to 52 fathoms. At 52 fathoms it was abundant on sandy mud. It was scarce on coarse grounds (Möbius, No. 87). Michaelsen also records it in the North Sea from sandy mud. The Norwegian North Atlantic expedition obtained it on clay at 135 fathoms and at 300 fathoms (Hansen, No. 36). The Porcupine dredged it at 725 fathoms (Ehlers, fide SaintJoseph, No 102); the Caudan on mud at 98 fathoms in the Bay of Biscay (Roule, No. 101). From these records it is clear that the species is generally found on mud or muddy sand.

Filograna implexa (Table VI.). Large colonies were present only in haul 103 (Ground XIII.), south-east of the Eddystone, probably owing to the fact that the wave action is somewhat less there than on the grounds to the westward of the Eddystone ( $c f$. p. 425). Small colonies, 
chiefly on shells of Pecten opercularis, were obtained on Grounds VII., IX., and XIV. The species is characteristic of the coarse grounds rather than of the fine sand.

Distribution. Geographical. East of North America, Faröe, North and West Norway, White Sea (?), Scotland, England, North and West of France, Mediterranean (fide Michaelsen).

Depth and Bottom-deposit. The Pommerania dredged Filograna implexa in the North Sea on "sand and Sabellaria tubes" at 12 fathoms, on sand and shell at 50 fathoms, on mud and on gravel and mud at 106 fathoms, on all of which grounds it was plentiful (Möbius, No. 87). The Norwegian North Atlantic expedition took it on clay at 415 fathoms (Hansen, No. 36), and the Caudan in the Bay of Biscay on gravel and sand at 98 fathoms, and on mud at 160 to 220 fathoms (Roule, No. 101). Saint-Joseph and Hornell both record it occasionally from the shore.

Dasychone bombyx (Table VI.). Common on both fine and coarse grounds, attached to shells, etc.

Distribution. North and West Norway, British Seas, North Sea, English Channel, Mediterranean (fide Saint-Joseph and Michaelsen). The Caudan took one specimen on a coral bottom at 220-270 fathoms in the Bay of Biscay. Saint-Joseph found it on the shore and in deeper water.

Protula tubularia. Occasional specimens only on the Eddystone coarse grounds and on two fine sand grounds (VII. and VIII.) immediately adjoining the latter.

Distribution. A southern species. Mediterranean, Atlantic, Channel. At Dinard it is found in from 2 to 15 fathoms. The Pola dredged it in 515 fathoms (fide Saint-Joseph, No. 102).

Serpula vermicularis. Not uncommon on all grounds where shells are present upon which it can fix.

Distribution. North-West and West Norway, Faröe, British Coasts, English Channel, Atlantic to Madeira, Mediterranean (fide Michaelsen and Saint-Joseph). The species was not obtained in the North Sea itself by either the Pommerania or by Michaelsen. The Norwegian North Atlantic expedition took it in 142 and 223 fathoms on grey clay and on sandy clay (Hansen, No. 36). The Caudan found it abundant on gravel and sand at 98 fathoms, abundant at three stations on mud from 104 fathoms to 219 fathoms, and at two stations on coral at 219 to 273 fathoms (Roule, No. 101). It would seem that this is a deep-water species, with its centre of distribution at depths of 100 to 300 fathoms, of which occasional individuals reach to the shore. This would explain the fact that although it has an extended distribution both north and south, it is not frequently taken in the North Sea.

Hydroides norvegica (Gunn). This serpulid is the common species growing on shells and on the stems of hydroids on all grounds where shells are present. On Grounds I. and II. it is found chiefly on Cardium echinatum shells. On many grounds it occurs on Buccinum undatum shells inhabited by Eupagurus Bernhardus.

Distribution. Norway, North Sea, Atlantic, Mediterranean ( fide Michaelsen and SaintJoseph). The species occurs on all kinds of grounds to deep water (300 fathoms, Norwegian North Atlantic expedition, Hansen, No. 36).

Potamoceros triqueter is much less common than Hydroides norvegica, but occurs on both fine and coarse grounds.

Distribution. Iceland, Faröe, North and West Norway, North Sea, British Coasts, French Coasts, Mediterranean (fide Michaelsen, No. 79, and Saint-Joseph, No. 102). 
Hornell (No. 49) found the species common on the shore, more sparingly in deeper water to 18 fathoms, in the Irish Sea. The Pommerania records also agree with the view that this species is most common in shallow water. Michaelsen records it, however, as plentiful in the North Sea to depths of 70 fathoms. On the whole it seems probable that $H$. norvegica has its centre of distribution in deep water, whilst that of $P$. triqueter is near shore.

Spirorbis sp. A species of Spirorbis is common on the hydroid Sertularia abietina, which is taken on Grounds II., XVII., and XVIII.

\section{NEMERTINA.}

The specimens have for the most part been named either by Mr. T. H. Riches or by Mr. W. I. Beaumont. For geographical distribution Bürger's Naples Monograph has been relied on.

\section{Crustacea.}

Nomenclature:-A good list of synonyms is given by Bonnier (No. 10), whose nomenclature has in most cases been used. In the identification of this group I have received much help from Mr. T. V. Hodgson.

For geographical distribution Norman (No. 93) and Gourret (No. 31) have been chiefly made use of. The records of the smaller crustacea, Amphipoda, Isopoda, etc., are very imperfect. For the Amphipoda Sars's Crustacea of Norway has been relied on for geographical distribution, and for the Cirripedia Darwin's monograph.

Homarus vulgaris. Two specimens of the common lobster were trawled on the fine sand of the inner trawling ground (I.) in haul 81 . Although the lobster generally frequents rocky places, it is not unusual for one or two specimens to be captured when trawling on sand.

Distribution. Geographical. West Norway to $62^{\circ}$ N., Sweden, Kattegat, British and French Coasts, Portugal, Mediterranean (not common). (Norman, No. 93; Bonnier, No. 10 ; Gourret, No. 31.)

Depth. Shore to 50 fathoms (?). (Lo Bianco, No. 68.)

Bottom-deposit. Rocky places. Gourret states that the lobster was formerly abundant at Marseilles, but that in 1888 it was only occasionally taken on the zostera beds.

Pandalus brevirostris, Rathk. Chart XII. Numerous on Grounds III. and IV., present on VII. and IX. This species is generally abundant only where hydroids or especially Cellaria abound, amongst which it is found hiding.

Distribution. Geographical. West Finmark, Norway, Sweden, Denmark, British Seas, Bay of Biscay (Norman, No. 93 ; Bonnier, No. 10). Carus (No. 14) gives it as a Mediterranean species, but I have found no other reference to its having been taken there.

Depth. 5 to 89 fathoms (A. O. Walker).

Bottom-deposit. Metzger (No. 78) records Pandalus brevirostris on sand and shell, on stones, and on stones and algæ in the North Sea (5-28 fathoms). Pruvot (No. 98) at Roscoff on sand from the coastal region. Meinert (No. 75) on mud and sand and on mud and small stones in the Kattegat. The distribution of the species therefore appears to have little direct connection with the nature of the bottom-deposit. It will probably depend largely on the distribution of hydroids and such polyzoa as Cellaria. 
Eupagurus Bernhardus. Chart XII. This hermit crab is present on grounds of all kinds, though it is most abundant on the sand and on the gravel and sand grounds where the fauna is generally rich. Its absence from Ground XIII., the gravel and mud one mile south-east of the Eddystone, is somewhat unexpected, but it must be noted that only one haul was made here (103). It is noteworthy that on the fine sand grounds (I., II., III., IV., V., and VII.) the anemone Sagartia parasitica was often associated with the hermit, whilst on all the other grounds the anemone was absent (cf. p. 459). Eupagurus Bernhardus was found occupying the shell of Buccinum undatum on all grounds excepting on the Bolt Head Shell Gravel (Ground XVII.), where specimens were taken (in hauls 106 and 107) in Fusus islandicus shells. The Buccinum shells often had Hydractinia echinata upon them.

Distributron. Geographical. East Finmark, Norway, Sweden, Kattegat, Baltic, British Coasts, Mediterranean (apparently not frequent).

Depth. Shore to 200 fathoms (Pocock, No. 96).

Bottom-deposit. Metzger (No, 78) records E. Bernhardus in the North Sea on sand, on gravel, on shell, and on mud, generally however, on fine ground. Meinert (No. 75) in the Kattegat on all kinds of ground, on clean sand, on mixed deposits, and on pure mud.

The distribution of this species is evidently little influenced by the nature of the bottomdeposit.

Eupagurus Prideauxii (Chart XII.) differs somewhat in distribution on the grounds investigated from E. Bernhardus, in that it is never found on the fine clean sand of the outer and inner trawling grounds (I. and II.). In other respects its distribution is practically the same as that of E. Bernhardus. It is invariably associated with the anemone Adamsia palliata.

Distribution. Geographical. Mediterranean, Portugal, Bay of Biscay, English Channel, Irish Sea, West of Scotland, Shetlands, Norway to Arctic Circle (Marion, No. 74 ; Gourret, No. 31; Bonnier, No. 10 ; Walker, Nos. 111 and 112 ; Hoyle, No. 52 ; Norman, No. 93). It is not recorded by Metzger in the North Sea, nor by Meinert in the Kattegat.

Depth. From 10 or 20 fathoms to 140 fathoms (Gourret, Milne-Edwards and Bouvier, No. 80$)$.

Bottom-deposit. Milne-Edwards and Bouvier (No. 80) record E. Prideauxii five times from fine sand, or muddy sand, and twice from sand, gravel, and broken shell, at depths from 30 to 140 fathoms in the Bay of Biscay. Marion (No. 74) records it in the Mediterranean on coralline gravel, on muddy sand, and muddy gravels. Walker (No. 111) in the Irish Sea on nullipore ground and on muddy gravel (20 fathoms).

Eupagurus cuanensis (Table VI.) is never found in large numbers on the grounds examined. It is confined for the most part to the gravel grounds in the neighbourhood of the Eddystone, but it was present in only comparatively few hauls. It is recorded once from the Bolt Head Shell Ground in haul 28. It is often found living in shells covered by suberites domuncula. 
Distribution. Geographical. South and West Norway, Sweden, Kattegat, Irish Sea, English Channel, Bay of Biscay, Mediterranean (Norman, No. 93; Meinert, No. 75 ; Walker, No. 112 ; Bonnier, No. 10).

Depth. Shallow water to 200 fathoms (Walker, No. 112, p. 80).

Bottom-deposit. On nullipore ground iu Irish Sea (A. O. Walker), on shell sand, 30-50 fathoms, off Concarneau (Bonnier). Meinert records it in the Kattegat on clean sand, on clean gravel, and on pure mud, as well as on the mixed deposits, sand, mud, and gravel, or gravel, mud, and small stones.

Anapagurus laevis (Table VI.). This species was sometimes taken in considerable numbers. It was more frequent on the fine sand than Eupagurus cuanensis, but it was also taken on Grounds XI. and IX., where the deposit is a mixture of gravel and sand. It was most numerous in hauls 104 (Ground II.), 93 (Ground IX.), and 90 (Ground V.). Its absence from Ground XIII. (gravel and mud) is noteworthy, as this ground in many ways resembles IX., where the species was numerous. On the Bolt Head Shell Gravel it was present in 27 only, a haul which in other respects gives indications of being partly a fine sand ground. On the Prawle Stony Ground it was taken in several hauls. On Ground IX. Anapagurus was common in shells of Turritella communis, and was also inhabiting shells of Natica nitida, Mangelia gracilis, and Nassa incrassata.

Distribution. Geographical. Mediterranean, Azores, Bay of Biscay, English Channel, Irish Sea, South-West Ireland, North Sea, Shetlands, Norway, Kattegat (Marion, MilneEdwards and Bouvier, Bonnier, Walker, Haddon, Metzger, Norman, Meinert). It is not recorded from the southern part of the North Sea.

Depth. 5 fathoms (Metzger, No. 78) to 383 fathoms (Marion, No. 74).

Bottom-deposit. Marion records Anapagurus laevis on deep mud in the Mediterranean (273 to 383 fathoms) ; Pruvot (No. 98) on coastal sand and on deep coral and mud (Mediterranean); Milne-Edwards and Bouvier (No. 80) on fine sand and on muddy sand in the Bay of Biscay (74-98 fathoms), on gravel, sand, and broken shell at the Azores (71 fathoms); Metzger (No. 78) on stones (5-20 fathoms), on gravel and shell (12 fathoms), on sand, on sandy mud, and on grey mud (50-80 fathoms) in the northern part of the North Sea. Norman says it is common on the Haddock (soft) grounds in the Shetlands. Haddon (No. 34) records it on coarse sand at the mouth of Bantry Bay (35-40 fathoms), and Meinert (No. 75) on mud with sand or gravel (70-22 fathoms) in the Kattegat.

It seems evident from the above records, and my own observations tend to confirm this, that Anapagurus laevis occurs most frequently on sand or mud grounds.

Porcellana longicornis (Table VI.). Like Galathea dispersa this species is found on all the grounds, and was taken in practically every haul, often in large numbers.

Distribution. Geographical. Norway, Sweden, Denmark, British Seas, Mediterranean (Norman, No. 93). Gourret (No. 31) states that it extends to the Canary Isles.

Depth. From low-water (Bell, No. 9) to 100 fathoms (Bonnier, No. 10). Milne-Edwards and Bouvier (No. 80) do not record it from any haul in the Bay of Biscay deeper than 10 fathoms.

Bottom-deposit. The species is recorded from all kinds of bottom, though, as in the case of many other very common and widely distributed species, very few records are to be found. 
Galathea dispersa was taken on all the grounds and almost in every haul. It was most rarely found on the clean shell gravel grounds, viz., Ground XVI., west of the Eddystone, and the Bolt Head Shell Gravel Ground (XVII.). It was most abundant where hydroids were numerous.

Distribution. Geographical. Norman (No. 93) gives South and West Norway, British Seas, and Mediterranean. Milne-Edwards and Bouvier (No. 80) found it commonly in the Bay of Biscay.

Depth. 5-140 fathoms (Milne-Edwards and Bouvier).

Bottom-deposit. The synonymy of the species is too doubtful to permit of a detailed list of references. Milne-Edwards and Bouvier took the species upon all kinds of ground in the Bay of Biscay.

Stenorhynchus longirostris. Chart XI. This species is most plentiful on Grounds IV., III., and V., where the bottom-deposit is fine sand (see Table VI.). It is less common on the still finer sands (Grounds I. and II.). It is present, though not numerous, on all the gravels west of the Eddystone with the exception of the clean shell gravel immediately adjoining the rocks (Ground XVI.). It is scarce on the Bolt Head Shell Gravel and on the Prawle Stony Grounds (XVII. and XVIII.).

The species is scarce or absent on those grounds on which branched hydroids of more or less luxuriant growth are scarce or absent respectively. It appears to be specially abundant where the prevailing hydroid is Sertularella Gayi (e.g., Grounds III., IV., and V.), less abundant where Halecium halecinum is the most characteristic representative of the group, as on the West Eddystone gravels. My notes are, however, not sufficiently full to establish this connection in detail for all the hauls.

Habits. The habit of this species of decking itself with bits of hydroids and polyzoa for the sake of protection is well known. When placed in a small aquarium with pieces of hydroid it will generally be found clinging to the hydroid. Whether or not it spends most of its time in a similar position in its natural haunts, or whether it is generally travelling about on the intervening patches of sand, I am not able to say, though from what I have seen of its habits in confinement I incline to the former view.

Distribution. Geographical. Stenorhynchus longirastris has a distinctly southern distribution. It occurs in the Mediterranean (Marion, No. 74 ; Gourret, No. 31 ; Norman, No. 93), Canaries and Portugal (fide Gourret), north coast of Spain (A. Milne-Edwards and Bouvier, No. 80), west coast of France (ditto and Bonnier, No. 10), north coast of France, Belgian Coast ( fide Metzger, No. 78), south coast of Devon and Cornwall, Irish Sea (scarce, A. O. Walker), Clyde (Hoyle, No. 53). The Pommerania took it once in the North Sea (south-east of Yarmouth), and it is not recorded from Norway nor from the Kattegat. Bell (No. 9) states that Embleton includes it in his list of Crustacea from Berwickshire and North Durham. It is not recorded in Firth of Forth by Leslie and Herdman (No. 43).

Depth. From 10 fathoms (Gourret) and 15 fathoms (A. O. Walker, No. 40, Vol. IX., p. 33) to 230 fathoms (Travailleur, No. 80, p. 5, footnote). 
Bottom-deposit. Milne-Edwards and Bouvier (No. 80), on gravel, sand, and broken shell and on fine sand, more frequently on gravel and coarse ground (5 stations) than on fine sand (2 stations) [Bay of Biscay and north-west of Spain, 30 to 150 fathoms]. Metzger (No. 78) on sand and shell (south-east of Yarmouth, 23 fathoms). Pruvot (No. 98), on mud and sand below 25 fathoms. Marion and Gourret (No.31), on sandy mud and deep mud (20-100 fathoms). Stenorhynchus longirostris appears to be most frequent amongst hydroids from about 20 to 50 fathoms. Its place is taken in shallower water by Stenorhynchus phalangium, and in the North Sea this species seems to replace it even in 30 to 50 fathoms (see p. 518). Its distribution appears to be only indirectly influenced by the nature of the bottom-deposit.

Inachus dorsettensis. Chart XI. On the whole the distribution of Inachus on the grounds under examination corresponds closely with that of Stenorhynchus longirostris, though it has never been met with in such great numbers as the latter species is when at its maximum. On the gravels to the west of the Eddystone it is more frequent than Stenorhynchus, though generally not represented by more than a few specimens in a haul.

Habits. Inachus dorsettensis is usually taken with its legs and often most of its carapace covered with growing sponges, compound ascidians, and polyzoa (Scrupocellaria scruposa). Occasionally specimens of Balanus are also attached to the carapace. It is a more sluggish animal than Stenorhynchus longirostris, and it does not seem to spend its time clinging to branching hydroids as that species probably does.

Distributron. Geographical. Mediterranean, Portugal, West France, British Seas, Kattegat, West Norway to latitude $62^{\circ} \mathrm{N}$. Only taken by the Pommerania in North Sea at one station (fide Norman, No. 93 ; Gourret, No. 31 ; Meinert, No. 75 ; Metzger, No. 78 ; Bonnier, No. 10). Apparently not common in Irish Sea (A. O. Walker, No. 112).

Depth. From about 6 fathoms (Gourret) to 136 fathoms (Milne-Edwards and Bouvier, No. 80).

Bottom-deposit. A. Milne-Edwards and Bouvier (Monaco expeditions) record the species from two stations on sand and gravel, and from seven stations on fine sand and on muddy sand. Metzger (P'ommerania) records it once on sand and shell. Pruvot, No. 98 (at Roscoff), from the lower littoral gravel. Gourret (at Marseilles), on gravels, on muddy sand, and on sandy gravel. Meinert (No. 75) (Hauch expedition), generally on gravel mixed with sand and mud; occasionally on pure mud or on clean sand. It thus appears that the species may occur on both gravel and sandy grounds, though according to the results of the Monaco dredgings it is more frequent on sand. I find no record of its having been taken on fine mud, but on grounds harder than this it appears to be distributed without immediate reference to the bottom-deposit.

Maia squinado was only taken in two hauls, both on fine sand grounds, in haul 56 on Ground III. and in haul 82 on Ground I. It is common amongst the rocks outside Plymouth Sound.

Distribution. Geographical. Mediterranean (general and common), Canaries, Portugal, West France, North France, southern and western coasts of England, and south coast of Ireland (Gourret, No. 31 ; Bonnier, No. 10 ; Pruvot, No. 98 ; Bell, No. 9). Not recorded from North Sea nor from Irish Sea.

Depth. Shore (Gourret) to 50 fathoms (Bonnier).

Hyas coarctatus. Several specimens were taken on the fine sand south of the Eddystone (Ground VI., hauls 101 and 102), one specimen on the sandy ground east of the Eddystone (Ground IV., haul 39), and 
one on the fine sand Ground I. (haul 50). The species was taken in no other hauls.

Habits. Most of the specimens were females carrying ova. They were more or less completely covered with compound ascidians, polyzoa (Scrupocellaria scruposa and Bicellaria ciliata), and large Balanus. In one case several specimens of Ascidiella scabra were attached.

Distribution. Geographical. An Aretic species, attaining both its maximum size and abundance within the Arctic circle. It is one of the three species of Crustacea Brachyura which are found in high latitudes (Norman, No. 93). It is circumpolar in distribution (Meinert, No. 75). The species occurs on the eastern and western sides of the Atlantic as follows:--Greenland, Labrador, Newfoundland, Norway, Sweden, North Sea (northern part, seldom in south), Irish Sea, South-West Ireland, English Channel, Brittany (vide Norman, Milne-Edwards and Bouvier, Meinert, Metzger, A. O. Walker, Pocock, Bell, Pruvot). It does not extend into the Kattegat (Meinert), nor is it taken on the west coast of France (Bonnier).

Depth. Shore (A. O. Walker, No. 112) to 250 fathoms (Pocock, No. 96).

Bottom-deposit. From the Irish Sea (A. O. Walker) Hyas coarctatus is recorded in stony places (0-10 fathoms), on small gravel and shells (15 fathoms), on sandy mud (30 fathoms), and on nullipore gravel (15-18 fathoms). Milne-Edwards and Bouvier (No. 80) record it from north of the Great Bank of Newfoundland on fine sand and small pebbles. Metzger (No. 78), in the North Sea, notes it generally on mud and sand. Pruvot (No 98), on the Brittany coast on gravel, and Meinert (No. 75), in 70 fathoms north of Skagen, on mud and fine sand. In the case of this species also it seems clear that the nature of the bottomdeposit is not a very-important factor in directly determining its distribution.

Eurynome aspera (see Table VI.). The only haul in which several specimens of this species were taken was haul 93 (Ground IX.), on the mixed gravel and sand west of the Eddystone. It was present in small numbers (one or two specimens in a haul) on nearly all the other grounds, both fine sand and gravel. The only grounds from which it is not recorded at all are V., X., XV., and XVI.

Habits. Not a burrowing species (Garstang, No. 29).

Distribution. Geographical. A southern species, especially abundant in the Mediterranean, where it is common on all kinds of ground from the shore to a depth of 140 fathoms. It is found on the coast of Portugal, west and north coasts of France, English Channel, Irish Sea, south-west of Ireland, Shetlands (rare, Norman, No. 90), south and west of Norway ; not recorded from North Sea, seldom in Kattegat (Marion and Gourret, Bonnier, Milne-Edwards and Bouvier, Walker, Pocock, Norman, Metzger, Meinert).

Depth. In Mediterranean, shore to 140 fathoms (Gourret, No. 31); south-west of Ireland, 315 fathoms (Pocock, No. 96). Shallowest depth recorded on British Coasts, 15 fathoms (Walker, No. 111).

Bottom-deposit. Gourret records Eurynome aspera in the Mediterranean from all kinds of ground, on gravel, on sand, on muddy sand, and on mud. A. Milne-Edwards and Bouvier (No. 80) found it on fine sand or muddy sand nine times, on sand with gravel three times in the Bay of Biscay and north-west of Spain. Walker (Nos. 111 and 112) records it in the Irish Sea from nullipore ground, from "reamy" bottom (i.e., mud and gravel), and from broken shell and small stones. In the Kattegat (Meinert, No. 75) it was taken generally on gravel mixed with small stones or with sand, more rarely with mud. It was seldom taken on pure mud. This is another example of a wandering species, the distribution of which does not depend directly to any great extent upon the nature of the bottom-deposit.

Portunus depurator. Chart XIII. Abundant only on Ground VI. (three miles east of the Eddystone), which is a sandy ground with many 
shells. The species was also present on Grounds III., VI., and VIII., which are also fine sand, and scarce on XIV. and XIII., fine gravel and coarse gravel with mud respectively. In Plymouth Sound it is abundant on stony ground in 5 fathoms.

Habits. A gregarious species (Bell), which can swim rapidly. It does not appear to burrow like many other species of this genus.

Distribution. Geographical. Mediterranean, Portugal, west coast of France, Channel Islands, English Channel, Irish Sea (abundant), Clyde area, Shetlands (rare, Norman), North Sea (once only, Pommerania), Kattegat (chiefly on deep mud), Norway to Arctic circle (vide Gourret, Bonnier, Bell, Walker, Hoyle, Norman, Metzger, Meinert).

Depth. 3 fathoms (Walker) to 104 fathoms (Hoyle, No. 53).

Bottom-deposit. In the Irish Sea Walker (Nos. 111 and 112) records it as abundant on stony ground in 3-7 fathoms. Metzger (North Sea, Ne. 78), on sandy mud in 69 fathoms. Pruvot (Mediterranean, No. 98) on sand, on gravel, and on mud. Marion (Mediterranean, No. 74), on mud and on muddy sand in 34-50 fathoms. Meinert (Kattegat, No. 75), generally on pure mud, occasionally on mud with sand or gravel, occasionally on clean sand. In this case again the species is found upon deposits of very different texture. In shallow water (3-10 fathoms) it appears to inhabit chiefly stony ground.

Portunus pusillus (Chart XIII.) was most numerous on the Gravel Grounds IX. and XI. to the west of the Eddystone. It was very rarely obtained on the fine gravel ground XV., and on the fine sand grounds IV., VI., and VII.. Occasional specimens were found on the Bolt Head Shell Gravel and on the Prawle Stony Ground. The species was never taken on the fine sand grounds I., II., III., and V.

On the whole; therefore, on the grounds under investigation, Portunus pusillus lives principally on gravel, a few wandering on to the sand grounds immediately adjoining the gravel.

Distribution. Geographical. Mediterranean, Canary Isles, Portugal, Bay of Biscay, English Channel, Irish Sea, Shetlands, Norway to Lat. $62^{\circ}$, Sweden, Kattegat, North Sea (Milne-Edwards and Bouvier, Norman, No. 93, Gourret, Bonnier).

Depth. Shore (rare, Bonnier, No. 10) to 98 fathoms (Milne-Edwards and Bouvier, No. 80).

Bottom-deposit. Milne-Edwards and Bouvier record Portunus pusillus from the Bay of Biscay on nullipore ground, on fine sand, and on muddy sand. Metzger (No. 78), on stony ground, on sandy mud, on gravel, and on sand. Pruvot (No. 98) mentions it on sand and gravel, and on gravel. Bonnier (No. 10), on muddy sand. Gourret (No. 31), on mud, on gravel, and on muddy gravel, and Meinert (Kattegat, No. 75), generally on mud mixed with gravel and stones, occasionally on fine sand.

Corystes cassivelaunus (Chart XIII.) is found practically exclusively upon clean fine sand, and is abundant on Grounds I. and III., or, speaking more accurately, on the portions of those grounds which adjoin each other. The hauls in which it was most plentiful are $91,72,57$, and 92 , which it will be seen all lie near together. One specimen only was taken on Ground II. (haul 22), and it was also met with on Ground XVII. (Bolt Head Shell Gravel) in haul 27 only, probably because this haul extended on to the fine sand. The species is entirely absent from all the Eddystone Gravel Grounds. 
Habits. The habit of Corystes cassivelaunus of burrowing in fine sand was recorded by several of the older naturalists (Couch, Gosse, Robertson), and recently Garstang has made a special study of the species in relation to this matter. He found that the crabs burrowed at once in fine sand, but would not burrow in gravel. They came out of the sand and became active at night.

Distribution. Geographical. Mediterranean, Bay of Biscay, English Channel, Irish Sea, West Ireland, southern part of North Sea only (not north of Scarborough) (Marion and Gourret, Pruvot, Bonnier, Walker, Metzger).

Depth. Between tide-marks (Walker) to 30 fathoms (E. J. A.).

Bottom-deposit. Corystes cassivelaunus is recorded by Marion and Gourret (Mediterranean, Nos. 74 and 31) on mud, rare; by Pruvot (No. 98), on mud and on sand; by Metzger (North Sea, No. 78), on sandy mud and on fine sand; by Holt (West Ireland, No. 48), on sand and on soft mud; by Walker (Irish Sea, Nos. 111 and 112), on sand.

Corystes cassivelaunus is a good example of a burrowing species whose distribution is directly controlled by the texture of the bottom-deposit.

Atelecyclus heterodon (Chart XIII.) was abundant on two grounds, on Ground XIII., one mile east of the Eddystone, where the bottom-deposit is medium gravel mixed with a considerable amount of mud (see Table II., Sample 103), and on Ground IX., three miles west of the Eddystone, where the deposit is coarse gravel mixed with fine sand (see Table II., Sample 94). On the muddy gravel the specimens were both large and numerous, on the sandy gravel they were numerous, though comparatively small. On the other grounds in the neighbourhood of the Eddystone occasional specimens only were taken, generally in not more than one haul, as follows: (Cf. Chart XIII.), Ground XI. (one in 47, one small one in 84), Ground X. (haul 42, small in 95), Ground VII. (hauls 38 and 100), Ground XV. (one in haul 97), and Ground IV. (in 34 only). One specimen was also taken on the fine sand of the inner trawling ground (I.) in haul 82. On the Bolt Head Ground (XVII.) the species was taken only in hauls 27 and 28 , which are the two hauls on this ground furthest from the shore, and differ in other respects from the remaining hauls. One or two specimens only were taken in these hauls, and the bottom is described from observation of the contents of the dredge as shells, broken shell, gravel, and sand. (At the time the hauls were made the taking of proper samples of the deposit with the canvas bag dredge had not been commenced.) On the Prawle Stony Ground (XVIII.) Atelecyclus was taken in haul 45 only on a bottom described as gravel, stones, and shells. (No sample taken.)

Habits. A burrowing species (Garstang, No. 29).

Distribution. Geographical. Mediterranean, Portugal, Bay of Biscay, Brittany, English Channel, South-West and West Ireland, Irish Sea, Shetlands (common), North Sea (northern portion), Norway to Aretic circle (Marion and Gourret, Pruvot, Bonnier, Bell, Holt, Walker, Norman (No. 93), Metzger). It does not appear to have been recorded from the southern part of the North Sea, nor from the Kattegat.

NEW SERIES.-VOL. V. NO. 4. 


\section{ON THE FAUNA AND BOTTOM-DEPOSITS NEAR THE 30-FM. LINE}

Depth. Shallow water to 400 fathoms (Bourne, No. 11). Milne-Edwards and Bouvier give several records between 50 and 100 fathoms.

Bottom-deposit. Marion (Mediterranean, No. 74) found small specimens of Atelecyclus on the mud at 100 fathoms. Gourret (Mediterranean, No. 31) records it from mud and under stones. Milne-Edwards and Bouvier (Bay of Biscay, No. 80), from muddy sand and from fine sand (50-100 fathoms). Walker (Irish Sea, No. 112), from broken shells and small stones (22 fathoms). Metzger (North Sea, No. 78), from sand and shells (50 fathoms). Pruvot (Brittany, No. 98), from gravel and (Mediterranean) from mud, from sand ( 30 fathoms) and from rocks and mud (shore).

These records are not very conclusive as to the nature of the ground which Atelecyclus usually frequents, but combining them with my own observations there seems to be reason for supposing that it likes muddy ground, but that the mud is generally mixed with a coarser deposit. Occasionally it is found on fine sand.

Ebalia tumefacta (Chart XI.) is abundant on the coarse gravel mixed with fine sand, which is found on the west side of the Eddystone (Grounds IX. and XI.). It is constantly present, though in much fewer numbers, on clean shell gravel grounds (XVI. and XVII.). One specimen was taken on the fine sand, Ground II., haul 23, but this was quite exceptional.

Distribution. Geographical. Mediterranean, Portugal, Bay of Biscay, British Coasts, Norway to Arctic circle (Gourret, No. 31 ; Norman, No. 93).

Depth. 25 fathoms (Metzger) to 98 fathoms (Milne-Edwards and Bouvier).

Bottom-deposit. Goodsir (fide Bell, No. 9, p. 143) states that this species is generally found on stony bottoms and on fishing-banks. Metzger (No. 78) records it once from the Pommerania dredgings in the North Sea on a bottom of sand and shells (25 fathoms). Walker (No. 112) records it on nullipore ground in the Irish Sea, and Pruvot (No. 98) on gravel at Roscoff and on coastal mud and sand in the Mediterranean. Gourret (No. 31) found it on very muddy sand (26-36 fathoms, Mediterranean); Bonnier on shell sand and coral bottom; Milne-Edwards and Bouvier in the Bay of Biscay on muddy sand.

Ebalia tuberosa. Chart XI. The distribution of E. tuberosa on the area under examination is almost exactly the same as that of $E$. tumefacta. Single specimens have, however, been taken in addition on Grounds VII., XIII., and VI. A. O. Walker (No. 112, p. 98) has drawn attention to the fact that these two species are almost invariably taken together, and has expressed a doubt as to their specific distinction. The differences between them are certainly very slight.

Distribution. Geographical. Mediterranean, Portugal, Bay of Biscay, British Coasts, Norway to Arctic circle (Gourret, No. 31; Norman, No. 93).

Depth. Shallow water (2 fathoms, Gourret) to 90 fathoms (Milne-Edwards and Bouvier).

Bottom-deposit. A. O. Walker (Nos. 111 and 112) records the species in the Irish Sea on nullipore ground, on broken shell and small stones, on stones and mud, and on shells, sand, and gravel. Milne-Edwards and Bouvier (No. 80) on muddy sand and on grey sand; Gourret (No. 31), on muddy gravel, on muddy sand, and on gravel. Bonnier (No. 10), at Concarneau, records it from the same grounds as $E$. tumefacta.

Ebalia Cranchii (Chart XI.) is only recorded on one ground in the neighbourhood of the Eddystone, viz., Ground XI. (hauls 8 and 9). It has been taken also on the Bolt Head Shell Gravel and on the Prawle Stony Ground, but only in small numbers. 
Distribution. Geographical. Mediterranean, Bay of Biscay, British Seas, Norway, Kattegat (Gourret, Bonnier, Norman, Meinert).

Depth. 8 fathoms to 550 fathoms (Bonnier, No. 10).

Bottom-deposit. Gourret (No. 31) records the species in the Mediterranean from muddy gravel and sand, from coralline gravel, from muddy gravel, and from muddy sand. Bonnier (No, 10) found it at Concarneau on the same kind of bottom as $E$. tumefacta. Pruvot (No. 98), on gravel, on mud and sand. Milne-Edwards and Bouvier (No. 80), on gravel, sand and broken shell, on fine sand, and on grey sand. Metzger (No. 78) records it in the North Sea three times on sand and shell, once on fine grey sand, and three times on mud and sand. Walker (Nos. 111 and 112) records it in the Irish Sea from shell sand and small gravel, and Haddon (No. 34) on the south-west coast of Ireland on coarse sand. In the Kattegat Meinert (No. 75) mentions it as occurring occasionally on pure mud, generally on mud with gravel or sand. The species therefore clearly is most plentiful on coarse deposits.

Gonoplax angulata. Chart XIII. (Following Fisher and Bonnier, $G$. angulata and $G$. rhomboides are here treated as one and the same species.) One specimen of this species only was obtained, on Ground V. (haul 90), four miles north-east of the Eddystone. As will be seen from Table II., the bottom-deposit on this ground consists of sand of a somewhat coarser texture than the majority of the fine sands examined, but containing at the same time a high percentage of silt ( 7 per cent.).

Habits. According to Cranch "they live in excavations formed in the hardened mud," and "their habitations, at the extremities of which they live, are open at both ends." It is probably on account of this habit that specimens of the species are so seldom captured.

Distribution. Geographical. Mediterranean, Canary Islands, Bay of Biscay, English Channel, Irish Sea, South-West Ireland (Gourret, Bomnier, Bell, Walker, Holt). It is not recorded from the North Sea or from Norway.

Depth. Shallow water to 50 fathoms (Bonnier, No. 10).

Bottom-deposit. A. O. Walker records Gonoplax on fine mud (45 fathoms) in the Irish Sea ; Holt (No. 48), on sand (45-48 fathoms) on the west coast of Ireland. Cranch (fide Bell, No. 9) found it in hardened mud (shore?) ; Marion (No. 74), on mud ; Gourret (No. 31), on muddy gravel and on mud. Bonnier (No. 10) states that at Concarneau the species is frequently taken by lobster fishermen in their pots.

\section{Mollusca.}

Nomenclature:-Lamellibranchiata and Gasteropoda, Forbes and Hanley, History of British Mollusca. For geographical distribution I have relied largely on Gwyn Jeffrey's British Conchology and on Locard (Travailleur et Talisman. Mollusca. No. 69).

Pholas parva. One specimen only, on the Prawle Stony Ground (XVIII.) in haul 4. The animal was found, along with numerous specimens of Pholadidea papyracea, boring in red trias rock.

The species is recorded boring in new-red sandstone, marl, clay, and submarine peat (Jeffreys, No. 55). Montague found it in decayed wood at Salcombe (Forbes and Hanley, No. 25). It appears to be a 
southern species, and has been recorded from Malaga and Algiers. There are also records from the Irish Sea.

Pholadidea papyracea. Like Pholas parva this species was taken in one haul only, viz., haul 4 on the Prawle Stony Ground. It was plentiful in pieces of red trias rock.

The species is recorded by Forbes and Gwyn Jeffreys from new red sandstone or trias, peat, submarine forest, sandstone, and hard clay. It has been obtained from the English Channel, Irish Coasts, and west of Scotland ( fide Jeffreys, No. 55). The Talisman expedition took it in 60 fathoms west of Morocco (Locard, No. 69). It is found from low-water mark (South Devon Coast) to 80 fathoms (off the coast of Antrim) [Jeffreys].

Saxicava rugosa (Table VI.). The variety arctica was found on grounds of all kinds attached to shells and similar objects, or to the roots of hydroids.

Habits. The varieties arctica and minuta do not bore like the common Saxicava, but are found attached to shells, etc., in deeper water.

Distribution. Geographical. Locard (No. 69), who regards S. arctica as a distinct species, gives its distribution as coast of Finmark, Norway, England, France, Bay of Biscay, and Mediterranean. The boring variety is found in all parts of the world.

Depth. Shore to 700 fathoms (var. arctica, Dauzenberg, No. 20).

Pandora obtusa $[=P$. inaequivalvis, var. obtusa of Gwyn Jeffreys]. One living example only taken in haul 75 (Ground VII.). The bottomdeposit is one of the coarser kinds of fine sand, and a large stone is recorded in this particular haul.

Distribution. Geographical. Gwyn Jeffreys.(No. 55) distinguishes two varieties of Pandora inaequivalvis; var. tenuis, with a southern range from Algeria to Guemsey, and north to Shetlands; var. obtusa ranging from Spitzbergen to the Canaries.

Depth. Low-water to 100 fathoms, var. tenuis; between 85 and 100 fathoms (Shetlands) [Gwyn Jeffreys]. Var, obtusa, 7-50 fathoms.

Bottom-deposit. In sand, Channel Islands, at low-water ; often among Zostera marina (Jeffreys). Usually on muddy ground (Forbes, No. 25). In the British Association Report (1850) Forbes records the species once from mud, twice from mud and stones, once from sand and gravel, twice from gravel, and once from nullipores.

Lyonsia norvegica. Taken once only alive in haul 7 on the Bolt Shell Gravel (Ground XVII.). Shells were taken on Grounds XI., XIII., and VII., all of them coarse grounds in the neighbourhood of the Eddystone.

Distribution. Geographical. Sea of Okhotsk, Iceland, Scandinavia, France, Mediterranean, Madeira (Jeffreys).

Depth. Shallow water (4 fathoms, Jeffreys; 7 fathoms, Holt, No. 48) to 100 fathoms (Forbes, Brit. Assoc. Rep., 1850).

Bottom-deposit. Sand (Jeffreys); shells, mud, corals, and weed (Holt); on shells, stones, and mud (Herdman, No. 40, Vol. IX., p. 37); on sand and mud, on stones and mud, on gravel, and on sand (Forbes, Brit. Assoc. Rep., 1850); on mixed deposits (sand or gravel and mud) [Petersen, No. 95]. From these records I should judge that the species was most frequent upon muddy gravel or sand.

Solen ensis has been represented by shells only. It is not unlikely that the species occurs in water of 30 fathoms, though from what is 
known of its habits on the shore there is little chance of its being captured by a dredge.

Solecurtus candidus. Shells only have been occasionally taken.

Distribution. Gwyn Jeffreys (No. 55) states that Solecurtus candidus is a very active species which lives in sand exposed at low-water spring tides, and also at various depths from 20-85 fathoms. Forbes and Hanley (No. 25) say that it probably buries deeply in pure sand. It is a southern species, extending from the English Channel to the Canary Islands and Madeira, and is also present in the Mediterranean (Jefireys).

Psammobia ferroensis. Shells only have been taken of this species.

Psammobia costulata. One specimen only on the clean shell gravel (Ground XVI.) immediately west of the Eddystone reef.

Distribution. Mediterranean, Madeira, Canaries, British Seas, Norway (Jeffreys).

Tellina crassa. One living specimen only was obtained in haul 99 and one in 87 , both on the clean shell gravel close to the Eddystone rocks (Ground XVI.).

Distrinution. Geographical. North Sea, French Coast, Gibraltar, and Gulf of Tunis (Jeffreys, No. 55).

Depth. Low-water to 55 fathoms (ditto).

Bottom-deposit. Forbes and Hanley say that the species generally lives in the upper part of the coralline zone in gravelly sand. At Herm, in the Channel Islands, it is found in sand at low-water, and also in the Isle of Man. Forbes (No. 24, Brit. Assoc., 1850) records it once on sand ( $35-40$ fathoms) and once on gravel ( 40 fathoms). In the Liverpool district it is recorded on small gravel with some melobesia (No. 40, Vol. IX., p. 33). The species appears therefore to prefer coarse ground.

Tellina donacina. Shells only in haul 9 (Ground XI.).

A southern species, not extending further north than the west coast of Scotland; south to Azores, Mediterranean, Red Sea (Locard, No. 69). The Challenger dredged it on volcanic mud in 450 fathoms off the Azores (Smith, No. 107).

Lutraria elliptica. Shells of this species were fairly common on all shelly grounds. They were generally old and much bored by Cliona.

The species extends from Finmark to the Mediterranean, and occurs in soft mud from low tide to 15 fathoms (Jeffreys). As the animal generally burrows very deeply in the mud, it is most unlikely that it would be captured by a dredge.

Tapes virginea. Although shells of this species, often very fresh, were exceedingly common on all shelly grounds, living examples were only rarely taken. These occurred on the fine gravel (XIV., hauls 41 and 88), on the clean shell gravel (XVI., haul 87), and on the Prawle Stony Ground (XVIII., haul 29).

Distribution. Geographical. Norway to Mediterranean, but its eapital is in the Celtic province (Forbes).

Depth. Shore to 145 fathoms (Jeffreys).

Bottom-deposit. Forbes (No. 24, Brit. Assoc., 1850) gives five records of the species living on sand, one on shell and nullipores. Metzger records it from the Pommerania expedition six times on stony or gravelly ground.

Venus verrucosa. One living specimen only was taken in haul 76 on Ground VII. The haul was apparently a mixed one, showing some characters of Ground XIV. (fine gravel), and some of VII. (sand with many shells). 
Distribution. Geographical. A southern species extending north to south and west Ireland, and south to Mediterranean, Canaries, Madeira, Cape Verde, and the Cape of Good Hope (Locard, No. 69).

Depth. Generally in littoral and laminarian zone; seldom beyond coralline zone (Locard). The Talisman took it off the Canaries in 100 fathoms.

Venus casina. Shells only of this species were taken.

A southern species extending from West Norway to the Mediterranean, Madeira, and Canaries, 5-145 fathoms (Jeffreys).

Venus striatula $[=$ Venus gallina $]$. Shells only taken.

From Iceland to Mediterranean. Sandy ground, low-water to 85 fathoms (Jeffreys, No. 55). Forbes (No. 24) records it frequently on sand, and on sand and mud; Metzger (No. 77) records it nine times on sand and shell or on sand and mud, and twice on mud; Heincke (No. 39) finds it frequent in the neighbourhood of Heligoland, chiefly on clean sand ground; and Petersen (No. 95) records it in the Kattegat on sand or on mixed deposits.

Venus fasciata (Table VI.). A few living specimens, chiefly on coarse grounds, viz. :-Ground XI., haul 9; Ground XVI., haul 13; Ground, XVII., hauls 6 and 68 ; and Ground XVIII., haul 45 .

Distribution. Geographical. From the North Cape to the Mediterranean (Jeffreys, No. 55).

Depth. Shore to deepest water around British Coasts (Jeffreys); 100 fathoms (Hoyle, west of Scotland, No. 52).

Bottom-deposit. Chiefly on gravel and gravelly sand in coralline zone (Forbes and Hanley). Metzger (No. 77) records it three times in the Pommerania dredgings, all on coarse ground. From the Liverpool district (No. 40, Vol. IX., p. 33) it is recorded on small gravel and shell. Petersen (No. 95) took it in the Kattegat on gravel and on sand.

Venus ovata. The shells of this species were very pientiful on all gravel and shell grounds. It was not, however, taken alive.

Distribution. Geographical. From Finmark to Mediterranean and Azores.

Depth. Shallow water to 1046 fathoms (Porcupine expedition).

Bottom-deposit. Forbes and Hanley state that the species has a preference for gravelly sand. Forbes (Brit. Assoc., 1850) records it from all kinds of bottoms; generally, however, gravel or sand. Heincke states that it is the commonest lamellibranch near Heligoland, and is frequent in muddy sand with shells and small stones at 16-32 fathoms. He also finds it on coarse sand and mud. Metzger (No. 77) took it in the North Sea nine times on coarse ground and four times on fine sand. Petersen (No. 95) found it in the Kattegat on mixed deposits (on gravel and mud, and on sand and mud).

Artemis exoleta. Two specimens were taken in haul 99 on the clean shell gravel (Ground XVI.) close to the Eddystone rocks. Shells of the species were also very numerous in the same haul, as well as on several other shelly grounds.

Distribution. Geographical. Finmark to Mediterranean.

Depth. Shore to 70 fathoms (Forbes, No. 24).

Bottom-deposit. Sandy ground (Forbes and Hanley). Forbes (Brit. Assoc. Rep., 1850) records it on shell and sand, on gravel, on nullipores, and on mud, as well as on sand.

Cyprina islandica. Shells only were taken on the grounds examined. These were present on the ordinary shell and gravel grounds, and also on Ground II., a fine sand ground upon which shells were not numerous.

Distribution. Geographical. Lapland, Iceland, Finmark, Norway, British Seas, French Coast, Bay of Biscay: also on the coast of New England. This is a distinctly northern species [fide Locard, No. 69]. 
Depth. Shallow water to 1150 fathoms (Porcupine).

Bottom-deposit. Generally on muddy sand (Jeffreys, Forbes and Hanley, Metzger, Heincke, No. 30).

Circe minima. One specimen in haul 76 on Ground VII., south-west of the Eddystone. This haul was probably first on gravel and then on fine sand with shells.

Distribution. Geographical. Finmark to Mediterranean, Azores, Madeira, and Canaries (Jeffreys, No. 55, and Dauzenberg, No. 20). Not recorded by Metzger in the North Sea, nor by Petersen in the Kattegat.

Depth. 5 to 704 fathoms (Jeffreys and Dauzenberg).

Bottom-deposit. Forbes and Hanley state that Circe minima occurs on nullipore and broken shell. Forbes (Brit. Assoc., 1850) records it generally on sand, on gravel, on nullipore, and on shell, once on sandy mud. The Challenger took the species off the Azores in 450 fathoms on volcanic mud (Smith, No. 107).

Astarte sulcata. Taken in three hauls only, viz., 95 (on Ground X.), 73 (on Ground XIV.), and 103 (Ground XIII.). Several specimens were captured in haul 95 ; in the other two hauls only one in each. Shells were found on Grounds X., XIV., and XVI.

The bottom-deposit on the grounds where the living specimens were obtained is in all cases gravel, mixed with fine sand and mud (see Table II.).

Distribution. Geographical. Lapland, Finmark, Norway to the Canaries. Rare in the Mediterranean (Locard, No. 69).

Depth. 7 to 1380 fathoms (Porcupine).

Bottom-deposit. Forbes and Hanley and Gwyn Jeffreys state that the species lives in muddy sand and in sand and mud. Forbes (Brit. Assoc., 1850) records it generally from coarse ground (nullipore, shell, gravel), as well as from sand, sandy mud, and once from mud. Metzger (No. 77) records it in the Pommerania dredgings seven times on coarse ground, once on mud. Herdman dredged it in Kors Fjord in 89 fathoms, the dredge coming up half full of mud and stones (No. 40, Vol. VI. p. 80). The same author also records the species $1 \frac{1}{2}$ miles west of Contrary Head in the Isle of Man on muddy sand with stones, and where there were many ophiurids. This ground must be very similar to the grounds upon which the species was taken near the Eddystone. Haul 95, where it was most abundant, was on Ground X., the special feature of which is the abundance of Ophiothrix fragilis, which generally nearly filled the dredge.

Cardium echinatum. Chart XIV. Although only one living specimen of the species was obtained, the distribution of the shells is in this case so characteristic that there can be little doubt that it affords some indication of the distribution of the living molluscs. The one living specimen was obtained in haul 75 on Ground VII., south-west of the Eddystone. As has been pointed out already (see p. 389), fresh shells of Cardium echinatum are a characteristic feature of the fine sand of the outer and inner trawling grounds (I. and II.), where they are constantly taken, and are the only shells of any size found on those grounds. Similar fresh shells are also frequent on the fine sand ground (VI.) three miles south of the Eddystone. The shells are somewhat less numerous on Ground VII., where the sand is coarser, and they are occasionally 
taken on the various gravel grounds west of the Eddystone, but on these latter the valves are generally separate, old, and worn. From what we know of the habits of the species in other localities the conclusion seems justified that the animal really lives on the fine sand (Grounds I., II., and VI.), but that it lives too deeply buried in the sand to be captured by the dredge.

Distribution. Geographical. Greenland, Scandinavia, British and French Coasts, Mediterranean, and Canaries (Jeffreys, No. 55).

Depth. 5-100 fathoms (Jeffreys).

Bottom-deposit. Forbes and Hanley (No. 25) give muddy ground, sandy mud, and muddy gravel. Metzger (No. 77), in the Pommerania dredgings, records young living specimens $(10-15 \mathrm{~mm}$.) on sandy mud and empty shells on fine sand. Heincke (No. 39) states that large empty shells are frequent on muddy ground, on which small living specimens are generally taken. In the Liverpool district fresh, large shells are abundant. An immense number of shells and some live specimens were thrown up at Southport, where the shore is sandy, in January, 1891 (No. 40, Vol. VI., p. 110).

Two species closely allied to Cardium echinatum have been distinguished by conchologists, namely, C. aculeatum and C. tuberculatum. The three species are said to differ somewhat in the relative proportions and solidity of the shell and in the length of the spines. These latter, which furnish the most characteristic distinguishing features of the three species, are long, curved, and sharp in $C$. aculeatum, short and stout in C. echinatum, and more like tubercles in C. tuberculatum. With regard to the habits of the two latter species the following quotation from Mr. A. R. Hunt's paper (No. 54) on "The Influence of Wave Currents on the Fauna inhabiting Shallow Seas" is important:- "The large cockle, Cardium aculeatum, is abundant in fine muddy sand off Paignton in Torbay. In this deposit the long spines of this species are of service to increase its holding powers. An allied species, C. tuberculatum, whose shell is rough and ribbed but not spined, dwells in hard sand at and below low-water mark off the same place. The two species are not commonly found living together, though I have found specimens of $C$. aculeatum that had been washed in from sea, and their spines denuded in the process, living side by side in hard ground with $C$. tuberculatum. In both these species the rough shells tend to prevent the molluses being readily dislodged by the waves. Each species keeps to the ground best suited to it. The spines of $C$. aculeatum would apparently be too great an impediment in burrowing in the hard sand, whereas the spineless shell of $C$. tuberculatum would afford insufficient hold in the soft sand. A very slight advantage from form or sculpture might be of great importance in saving the cockles from local extinction; for in the case of Torbay the struggle for existence is so severe that both species are occasionally washed on shore in sufficient quantities to be carted away for manure."

Cardium echinatum is an intermediate form standing between $C$. 
aculeatum and C. tuberculatum, and specimens are constantly taken, which are very difficult to distinguish from one or other of these forms. The fine sand in which Cardium echinatum lives on the Eddystone Grounds could hardly be described as fine, muddy sand, as it contains a comparatively small quantity of silt, and it seems probable that the species lives in sand intermediate in texture between that described by Hunt as occupied by $C$. aculeatum and by $C$. tuberculatum. The case is one of those in which it is extremely difficult to decide whether we are dealing with one species, which grows in a different manner according to the nature of the ground which it occupies, or with three closely-allied species, each specially adapted to sand of a particular texture. Such questions can only be settled by experimental breeding of the species.

Cardium norvegicum. The distribution of this species is shown on Chart XIV. and should be contrasted with that of Cardium echinatum (fresh shells). The species is most abundant on Ground XIV., which is a fine gravel ground. It extends on to the grounds immediately surrounding this, but is not abundant on the coarse gravel mixed with fine sand, one living one only being taken on Ground IX. Living specimens were also taken on Ground IV., which in other features indicates the influence of fine gravel as well as sand.

Distribution. Geographical. Finmark, British Coasts to Mediterranean, Azores (Locard, No. 69), Madeira, and Canaries (Jeffreys, No. 55).

Depth. 10 or 15 to 1200 fathoms (Talisman, No. 69).

Bottom-deposit. Forbes and Hanley state that the species occurs on sandy or gravelly bottoms; Forbes (No. 24, Brit. Assoc., 1850) records it from shell; Gwyn Jeffreys says that it is found on sandy and nullipore bottoms. Metzger (No. 77) gives three records from the Pommerania dredgings, viz., on stony ground, on fine sand with small balls of mud, and on fine sand with pieces of shell. From the Liverpool district the species is recorded from small gravel and shells (No, 40, Vol. VI., p. 110). Petersen (No. 95) says that in the Kattegat the species seems to prefer sand to soft, mixed grounds.

From the above records it is, I think, clear that this species is found especially on coarse ground, such as broken shell and nullipore ground. C. norvegicum, which has a perfectly smooth shell, may therefore be regarded as completing the series presented by $C$. aculeatum, with long spines, living in fine muddy sand; C. echinatum, with stout spines, living in fine sand; and $C$. tuberculatum, with tubercles, living in " hard" sand.

Montacuta substriata. This mollusc was invariably found attached to the spines of Spatangus purpureus, the position in which it is commonly found. Gwyn Jeffreys states that it sometimes occurs also on Echinocardium cordatum and on other sea-urchins.

Distribution. Finmark to Mediterranean.

Kellia suborbicularis. Table VI. This species, taken on Grounds VII., IX., X., and XIV., west of the Eddystone, was generally found living 
in fine mud in the interior of dead lamellibranch shells, the valves of which had remained together.

Distribution. Geographical. Finmark to Mediterranean and Canary Islands (Jeffreys). Kerguelen Islands (Challenger, No. 107).

Depth. Low-water to 809 fathoms (Porcupine).

Bottom-deposit. Both Forbes and Hanley, and Gwyn Jeffreys mention the habit of this species of living in the mud inside dead bivalves. Jeffreys also states that it is sometimes found under stones at the lowest range of spring tides, sometimes in the excavations made by other animals in rocks

Modiola sp. Small specimens of Modiola, which I am inclined to regard as young Modiola modiolus, were frequently taken attached to shells and at the roots of Cellaria, hydroids, etc. Modiola barbata has also been recorded.

Nucula nucleus. Two living specimens only were taken, one in haul 76 (Ground VII.) and one in haul 103 (Ground XIII.). The former haul (76) is probably a mixed haul, first on fine gravel and then on somewhat coarse sand. Haul 103 is on gravel mixed with a good deal of mud. Empty shells were taken on Grounds VI., XIII., and XIV.

Distribution. Geographical. Lofoten Islands; British Coasts, etc., to Morocco and the Mediterranean (Locard, No. 69).

Depth. 3 fathoms (Jeffreys) to 219 fathoms (No. 61, Caudan expedition).

Bottom-deposit. Forbes and Hanley (No. 25) state that Nucula nucleus frequents coarse bottoms (7-10 fathoms) and gravel, or muddy gravel to 90 fathoms. Forbes (No. 24, Brit. Assoc., 1850) records it from gravel, from stony ground, from nullipores, from sand, and occasionally from mud. Gwyn Jeffreys says it is common on sand and gravel. Metzger (No. 77) records it on sand and shell, on mud and sand, on fine sand and on mud. Heincke (No. 39) states that at Heligoland the species is very common on fine muddy sand with shells and small stones, where it is associated with Venus ovata, Cardium fasciatum, and Trochus tumidus. Petersen (No. 95) records it from mixed deposits (muddy sand and gravel). On the whole, therefore, we may conclude that the natural home of the species is upon gravels and coarse sand mixed with mud. The following species $(N$. nitida) is found largely on fine sand as well as on coarser ground.

Nucula nitida. This was only taken once, viz., on the outer Eddystone Trawling Ground (II.) in haul 104. It was obtained in the sample of fine sand brought up with canvas bag dredge. This explains why it was not seen in the other hauls on Ground II. Several living specimens were buried in the fine sand (for the composition of this sand see Table II.), and its shells were very numerous.

Distribution. Geographical. Greenland, Norway, British Coasts to Mediterranean (Jeffreys, No. 55).

Depth. Low tide-mark to 86 fathoms (Jeffreys); to 100 fathoms (Hoyle, No. 52).

Bottom-deposit. Forbes and Hanley state that the species occurs on sand in shallow water, whilst Gwyn Jeffreys says only that it is found with Nucula nucleus, but is neither so generally diffused nor so plentiful. Forbes (Brit. Assoc., 1850), gives several records, the majority (eight) being on coarse ground, whilst four are on sand or on sandy mud. Metzger (No. 77) mentions it twice in the Pommerania dredgings on grey calcareous mud and on mud. Petersen (No. 95) says that in the Kattegat Nucula vitida is never found on the 
mud ("clay"), is occasionally met with on sand and mud, but that it prefers clean sand. Heincke (No. 39) states that near Heligoland it is frequent on pure mud, or mud with a little sand mixed, and that it only occasionally occurs with $N$. nucleus.

It must be admitted that the above records are not very consistent, and cannot be held to afford much confirmation of the idea that $N$. nucleus is a coarse ground species (gravel, broken shell, nullipores, etc.) whilst $N$. nitida prefers fine sand.

Arca tetragona. A few small specimens attached to shells, etc., on the Bolt Head Shell Gravel (XVII.) and on the Prawle Stony Ground (XVIII.).

Distribution. Geographical. Finmark to Mediterranean, Azores and Canaries (Jeffreys).

Depth. Shore to 450 fathoms (Challenger, No. 107); to 704 fathoms (Monaco expedition, No. 20).

Bottom-deposit. Crevices of rocks and chinks of old shells (Forbes and Hanley).

Pinna pectinata. Shells only of this species were obtained. Small single valves were moderately frequent on the Eddystone Grounds.

Distribution. Geographical. British Coasts to Mediterranean and Canaries. On British Coasts it appears to be only common in the western portion of the English Channel.

Depth. Low spring tides to 320 fathoms (Porcupine).

Bottom-deposit. In muddy and sandy gravel (Jeffreys). According to Forbes and Hanley, Montagu found the species in Salcombe Bay at low spring tides, sticking in the gravel with the valves upright, the broader end about one inch above the surface.

Pectunculus glycimeris. Chart XV. Both living specimens and shells of this species were abundant on the Bolt Head Shell Gravel (Ground XVII.) and on no other ground. One small living specimen was obtained on the Prawle Stony Ground (XVIII.) in haul 29, and another small one in haul 97 on the fine gravel (Ground XV.) east of the Eddystone. Shells were occasionally taken on the gravels west of the Eddystone (see Table VI.), but they were never abundant. Tubiclava cornucopiae is often found growing on the posterior end of living examples of this bivalve (see p. 445).

Distribution. Geographical. Lofoten Islands to Mediterranean, Madeira, and Canaries.

Depth. 7 fathoms (Jeffreys) to 250 fathoms (Porcupine).

Bottom-deposit. Forbes and Hanley say of this species that it is gregarious and prefers a nullipore bottom. Forbes (Brit. Assoc., 1850) gives records from sand, gravel, nullipores, and mud and stones. Gwyn Jeffreys says it occurs on sandy and shelly gravel and on nullipores. Pectunculus glycimeris is not recorded by Metzger in the North Sea, nor by Petersen in the Kattegat. In the Liverpool district it is recorded on nullipore ground (No. 41, p. 319), on stones, sea-weeds, and dead shells (No. 41, p. 323), on shells, stones, and echinoderm spines (No. 40, Vol. VIII., p. 20), and on shells, sand, and gravel (No. 40 , Vol. IX., p. 34). It is clearly very generally confined to coarse grounds.

Lima Loscombii. Chart XV. This species was most numerous in haul 10 on the clean shell gravel north-west of the Eddystone (Ground XVI.), and several living specimens were taken in haul 46 on the coarse gravel and sand of Ground XI. In both these hauls the shells were also numerous. Single living specimens were taken in hauls 35 
and 41 (Ground XIV.), haul 75 (Ground VII.) and haul 93 (Ground IX.), all of them coarse grounds to the west of the Eddystone.

In one haul on the Bolt Shell Gravel (haul 27, Ground XVII.) several specimens of the species were taken, but it was not captured alive in other hauls in the neighbourhood of Bolt Head and Prawle.

No specimens were taken on any of the fine sand grounds.

Distribution. Geographical. Greenland, Iceland, Scandinavia to the Mediterranean, Azores, and Madeira (Jeffreys, No. 55, and Locard, No. 69). Tristan da Cunha (Challenger).

Depth. Shore at low-water (Forbes and Hanley) to 1480 fathoms (Porcupine).

Bottom-deposit. Forbes and Hanley state that Lima Loscombii occurs on gravel, on nullipores, and on scallop-banks. Forbes (Brit. Assoc., 1850) gives eight records, all on gravel, on shell, on nullipore, or on stony ground. Gwyn Jeffreys says it lives on sandy or gravelly ground. Metzger (No. 77) records it once only in the Pommerania dredgings (Hongesund Schären) on stony ground. In the Liverpool district it is recorded on nullipore ground (No. 41, p. 319) and on "reany bottom" (i.e., sand or gravel mixed with mud). Petersen (No. 95) found it in the Kattegat eight times on muddy gravel, four times on sand and mud, and four times on mud or pure mud ("Slik" or "Ren Slik"). The Challenger (No. 107) took it off the Azores in 450 fathoms on volcanic mud.

From the above records it appears that the species is usually found on coarse ground often, if not generally, mixed with mud, but that it may occur also on mud.

With regard to the nest-building habit of Lima Gwyn Jeffreys says that this species ( $L$. Loscombii) seldom makes a nest, although specimens in nests have been seen both by himself and by Sars. He remarks further that "in all probability this habit depends on the nature of the sea-bottom. When the latter is soft mud the Lima can partly bury itself, and does not require to be otherwise protected from its voracious enemies. The haddock seems fond of it, the shells being often found in its stomach."

Pecten maximus. Chart XIV. Moderately abundant on the various gravel grounds in the neighbourhood of the Eddystone, two or three specimens being generally taken in each haul of the dredge. It was most numerous on Ground IX., where the bottom-deposit is coarse gravel mixed with fine sand. The species was entirely absent from the fine sand grounds and from the Bolt Head shell gravel. On the Prawle Stony Ground one small specimen only was obtained (in haul 4).

Distribution. Geographical. Norway, British Seas, France, etc., to Azores, Madeira, and Canaries (Jeffreys, No. 55 ; Locard, No. 69). The species does not appear to be common in the North Sea. Metzger (No. 77) gives no records from the Pommerania North Sea dredgings, and Heincke (No. 39) does not record it from Heligoland. Forbes and Hanley state that Bean took only three alive during very many years at Scarborough. It is scarce in the Kattegat (No. 95).

Depth. Shallow water (Forbes and Hanley, 3 fathoms) to 848 fathoms (Locard, No. 69, Azores).

Bottom-deposit. Forbes (Brit. Assoc., 1850) records living Pecten maximus twice from shell, once from gravel, once from sand. Metzger (Pommerania expedition) gives one record (Sölsvig, 0-20 fathoms) on stones and bivalve shells. Petersen (No. 95) found it three times in the Kattegat on gravel and small stones, on shell gravel, and on gravel, mud, and stones. In the Liverpool and Isle of Man districts $P$. maximus is recorded on nullipore ground, on fine gravel, on muddy sand and stones, and on sand and shell fragments (No. 40 , Vol. IX., pp. 33 and 34 ; No. 41, p. 319). In the record on muddy sand and stones it is stated that many ophiurids were present, which indicates a similarity with the gravels to the west of the Eddystone, where we have obtained the species. In the Isle of Man haul, on saud and shell fragments, Pectunculus glycimeris was also taken. On the grounds 
described in the present report $P$. glycimeris was only numerous on the Bolt Head shell gravel, and on this ground $P$. maximus was never taken. The above records show that Pecten maximus is generally found on coarse ground, especially where there is a considerable admixture of mud.

Pecten opercularis. Chart XIV. This, as is well known, is a gregarious species often occurring in large shoals or flocks. These shoals are often of comparatively limited size, so that two hauls near together, and taken on what have been regarded as the same ground, have differed very much in the number of $P$. opercularis captured. The species was taken in larger or smaller numbers on each of the eighteen grounds into which the district examined has been divided, and Chart XIV.indicates roughly the relative frequency upon the different grounds. The species is most numerous on the Eddystone gravels and on the sand immediately outside these. The largest beds occurred on Grounds IV., IX., and XIV. On the fine sand of the outer trawling ground (Ground II.) many specimens were captured in one haul only, viz., haul 24. On the Bolt shell gravel and on the Prawle Stony Ground $P$. opercularis was never numerous, and was generally not taken at all.

On all the Eddystone Grounds young Pecten opercularis from about $0.5 \mathrm{~mm}$. breadth were abundant, attached to hydroids (especially Halecium halecinum and Sertularella Gayi), wherever these were common, both on gravel and on fine sand bottoms.

Distribution. Geographical. Norway to Mediterranean, Azores, Madeira, and Canaries (Locard, No. 69).

Depth. 5 fathoms (Forbes and Hanley) to 1457 fathoms (Poreupine).

Bottom-deposit. The records, which are fairly numerous for this species, indicate that the molluse may occur on both coarse and fine bottoms, on gravel, on sand, or on mud. In the Kattegat Petersen (No. 95) found $P$. opercularis chiefly on the mixed deposits and not on the pure mud. On the latter $P$. radiatus was the frequent species.

Pecten tigrinus (Table VI.). Living specimens of this species were not abundant, one or two in a haul being the largest number taken. Shells also were not very numerous. The living specimens were for the most part taken on coarse ground.

Distribution. Geographical. Iceland, Scandinavia, British Seas to Vigo Bay (Jeffreys, No. 55).

Depth. 7 fathoms (Jeffreys) to 106 fathoms (Pommerania, No. 77).

Bottom-deposit. Forbes and Hanley state that the species is found on shells, gravel, and sandy mud. Forbes (No. 24, Brit. Assoc., 1850) gives seven records on nullipore, on gravel, or on shell, three on sand, one on sandy mud, and one on mud. Gywn Jeffreys says that the species is found on a sandy bottom mixed with gravel. Metzger (No. 77) records it three times on stony ground, once on sand, and once on mud. Petersen (No. 95) found Pecten tigrinus (living) in the Kattegat three times on gravel or shell, five times on sand and mud, and once on mud. In the Liverpool district it is recorded on shell and gravel (No. 40, Vol. IX., p. 33). The species may be found on either gravel, on sandy mud, or on mud, and its distribution seems to be little influenced by the nature of the deposit.

Anomia ephippium and Anomia patelliformis. These two species are found on all grounds where they can tind suitable places of attachment. 
These they find least frequently on the fine sand grounds. Anomia is taken attached to stones, shells-both living and dead-worm tubes, and various crabs, especially Inachus dorsettensis and Hyas coarctatus.

Distribution. Geographical. A. ephippium-Iceland, Finmark, Lapland, Norway, West Europe to Madeira and Azores; Labrador, Brazil, Cuba, and Corea (fide Locard, No. 60). A. patelliformis-Lofoten Islands to Azores, North-East America (ditto).

Depth. A. ephippium-Low-water (Jeffreys) to 1118 fathoms (Lightning, fide Locard, No. 69). A. patelliformis - 10 fathoms (Jeffreys) to 771 fathoms (Porcupine).

Bottom-deposit. The authors for the most part state simply that the animals are found attached to stones and shells.

Chiton asellus. On all grounds where there are suitable objects, shells, stones, etc., upon which it can fix. Least frequent on the fine sand grounds. A favourite locality is on Lepralia foliacea when that polyzoan is present.

Distribution. Geographical. Greenland, Iceland, Scandinavia, British Seas, Vigo Bay, Mediterranean (Jeffreys).

Depth. Laminarian zone to 145 fathoms (Jeffreys).

Bottom-deposit. The authors all state that $C$. asellus is common on shells and stones.

Chiton discrepans. Two specimens (flesh-coloured) were found on the Prawle Stony Ground (XVIII.), on red trias rock, in haul 4.

Gwyn Jeffreys states that this species is found in the Channel Islands, Cornwall, French Coast, and in the Mediterranean, from low-water to 25 fathoms.

Dentalium entalis (Chart XV.) has been obtained on all fine sand grounds upon which the dredge, fitted with a canvas bag, has been used, with the exception of haul 104 on the fine sand of the outer trawling ground (Ground II.). It is seldom captured by the ordinary dredge or by the trawl. Occasionally only on gravel grounds.

Distribution. Geographical. Iceland, West Europe to Mediterranean, State of Maine, and North-West America (Jeffreys).

Depth. 3 fathoms (Jeffreys) to 300 fathoms (Herdman, No. 40, Vol. VI., p. 82).

Bottom-deposit. Forbes (No. 24, Brit. Assoc., 1850) records it thirteen times from gravel, shell, or nullipore bottom, seven times from sand, six times from sandy mud, five times from mud. Metzger (No. 77) records it generally from muddy sand in the North Sea. Petersen (No. 95) in the Kattegat from deposits containing a considerable admixture of mud ("stærkt lerblandet Bund"). Herdman records it from mud at 200 fathoms in Norway (l. c., p. 80).

Pileopsis hungaricus. This species has been taken only on the gravels west of the Eddystone (Grounds XI., IX., X., and XIV.) and on the Bolt Head Shell Gravel (XVII.). It is found attached to shells.

Distribution. Geographical. Iceland, Finmark to Gibraltar, and Mediterranean (Jeffreys).

Depth. 7-145 fathoms (ditto).

Bottom-deposit. The authors agree in stating that the species occurs on rocky and stony ground or on shells.

Emarginula reticulata (Table VI.) =E. fissura of Jeffreys. Very constant, but seldom in great numbers, on all the grounds where shells (upon which it creeps) are plentiful. 
Distribution. Geographical. Finmark to Mediterranean and Canaries (Jeffreys, No. 55, and Locard, No. 69).

Depth. Shore to 809 fathoms (Porcupine).

Bottom-deposit. Forbes (Brit. Assoc., 1850) gives many records, all on coarse ground. Metzger (No. 77) found it on stony ground and Petersen (No. 95) on mixed deposits. Gwyn Jeffreys says it occurs everywhere on shells and stones from low-water to 145 fathoms.

Emarginula rosea. Once only, in baul 8, on Ground XI.

Distribution. Geographical. South Coast of England, French Coast, and in the Mediterranean (Jeffreys).

Depth. 7-25 fathoms (Jeffreys).

Bottom-deposit. Forbes (Brit. Assoc., 1850) gives two records, on gravel and nullipores and on shell.

Trochus granulatus. On the Eddystone Grounds this species was taken on IX., XI., and XIII., all of them with a bottom-deposit of coarse gravel mixed with sand or muddy sand. One specimen was also taken on the Bolt Head Shell Gravel (XVII.) in haul 27, where the bottom is recorded as shells, broken shells, gravel, and sand.

Distribution. Geographical. Scottish and English Coasts, France, Spain, Canaries, Madeira, and Mediterranean (Jeffreys, No. 55 ; Locard, No. 69).

Depth. Coralline zone to 2105 fathoms (Travailleur, Locard).

Bottom-deposit. Forbes (No. 24, Brit. Assoc., 1850) gives three records, on shell, on mud and stones, and on gravel.

Trochus zizyphinus. The small deep-water variety of this species was occasionally taken, viz., on Grounds XIV. (fine gravel) and XVII. and XVIII., the Bolt Head Shell Gravel Ground and the Prawle Stony Ground respectively.

Distribution. Geographical. Finmark to Canaries and Mediterranean.

Depth. Shore to 450 fathoms (Challenger, No. 107).

Bottom-deposit. The chief habitat is on sea-weeds and rocks on the shore and in the laminarian zone. Records from deeper water by Forbes (Brit. Assoc., 1850) are from all kinds of bottom. The Challenger specimen was from volcanic mud off the Azores.

Turritella communis. Chart XV. Both shells and living specimens of this species were numerous on Ground IX. (hauls 93 and 94), which has a bottom-deposit composed of a mixture of coarse gravel and fine sand. The only other haul in which living specimens were taken was haul 39 on Ground IV. (three miles east of Eddystone).

Distnibutron. Geographical. Lofoten Islands to Mediterranean (Jeffreys, No. 55).

Depth. 5-100 fathoms (Jeffreys). Forbes and Hanley say that it occurs in immense numbers in some places in 7-10 fathoms. In 219 fathoms (Koehler, No. 61).

Bottom-deposit. Forbes and Hanley (No. 25) state that the species lives especially in muddy and weedy localities. Forbes (Brit. Assoc., 1850) gives nine records on mud mixed with stones, gravel, or sand; eight on gravel or stones or nullipores; four on sand. Metzger (No. 77) gives five records from the Pommerania dredgings on sandy mud, one on mud, one on stones, and one on sand, shells, and small stones. Petersen (No. 95) found the species in the Kattegat on mixed deposits (sand or gravel with mud) and on mud, but not on clean sand. The Liverpool Biological Society (No. 40) give three records, on sandy mud ( 30 fathoms), on mud in 34 fathoms, and on the deeper mud in 50 fathoms, where it is a characteristic species. 
From the above records it is clear that Turritella communis generally frequents a bottom of soft mud, or one in which there is a considerable proportion of mud mixed with coarser deposits. Under these circumstances it seems rather strange that it should have been abundant near the Eddystone on Ground IX., whilst it was absent on Ground XIII. As will be seen from Table II., the bottom-deposits on these two grounds are both coarse gravel, mixed in the one case (IX., haul 94) with fine sand, in the other (XIII., haul 103) with mud; that is to say, the percentage of silt in the latter case is very much greater than in the former. We should have expected to find Turritella abundant on the more muddy ground, but this is not the case.

Aporrhais pes-pelecani. This molluse was only twice obtained living, once in haul 87 on the clean broken shell of Ground XVI., and once in haul 55 on the coarse gravel mixed with fine sand of Ground X., both on the west side of the Eddystone. Shells were frequently taken on many other grounds, especially on the gravels to the west of the Eddystone. These shells were sometimes occupied by hermit crabs, sometimes by Phascolion strombi.

Distrinution. Geographical. Iceland, Finmark, British Coasts to Gibraltar and Mediterranean (Jeffreys, Locard).

Depth. 5 fathoms (Jeffreys) to 200 fathoms (Herdman, No. 40, Vol. VI., p. 80).

Bottom-deposit. Forbes and Hanley say that Aporrhais pes-pelecani is found on gravelly bottoms. Forbes (Brit. Assoc., 1850) gives seven records on coarse ground, two on sand, one on sandy mud, and three on mud. Metzger gives four records from the Pommerania dredgings, viz., on fine sand and shell, on sand, on muddy sand, on shell and small stones. Petersen found the species frequently all over the Kattegat, generally on the mixed deposits (muddy sand or muddy gravel), occasionally on pure sand, seldom on mud. Heincke (No. 39) found it at Heligoland only on muddy sand with some gravel. Herdman found Aporrhais pes-pelecani in Norway on mud and stones and on mud (200 fathoms). In the Liverpool district Herdman records a very large number of living specimens opposite Fleshwick Beach in 13 fathoms (No. 40, Vol. VIII., p. 18). In his subsequent paper on the floor deposits of the Irish Sea (No. 44) the same author describes a sample of the bottom-deposit off Fleshwick Bay in 12 fathoms, which, I presume, refers to the spot where these specimens were taken. This deposit consisted of slaty gravel mixed with shells, and with fine material consisting of sand and a very fine "sand flour." Herdman also records the species west of Fleshwick Bay, $\frac{1}{4}$ mile off shore, in 13 fathoms, on fine sand and broken shell (No. 40, Vol. IX., p. 32). From these records it seems probable that the distribution of Aporrhais pes-pelecani is not directly influenced by the nature of the bottom deposit, and that the animal can live upon any kind of bottom, provided the food supply and other conditions are satisfactory. It appears, however, that it is upon muddy gravel that the species finds the conditions most suited to its needs and that it is most abundant With reference to the peculiar shape of the shell of this animal, the following suggestion, due to Mr. A. R. Hunt from his paper, "On the Influence of Wave Currents on the Fauna inhabiting Shallow Seas" (No. 54), is worth quoting in full :- "The Gastropod Aporrhais pes pelecani is a sluggish molluse that frequents exposed areas of sand a few fathoms below the surface of the water. Its long wing-like processes, jutting out on one side of the shell, though affording the animal a broad base on which to rest, appear at first sight to be a source of danger in case it were overturned. They are in reality self-acting pieces of mechanism that will, in the majority of instances, ensure the molluse being ultimately left in its normal posture should it encounter wave currents 
sufficiently strong to upset it. On examining a specimen of Aporrhais pes-pelecani it will be seen that, when on its back, it lies indifferently on either side of a line drawn between two points, of which the end of the middle wing-like process is one, and one of the nodules on the body-whorl the other. The shell will rock freely backwards and forwards across this line; and experiment proves that a very moderate alternate current will suffice to replace the shell in its normal position. I have tried this experiment over and over again, not only with Aporrhais, but also with heavy foreign shells furnished with spines, processes, and more or less developed lips, such as Murex, Pteroceras, and Strombus. In many cases the righting action of wave currents is most marked."

Eulima polita. Living specimens of Eulima polita were obtained twice, once in haul 84, on the coarse gravel mixed with fine sand of Ground XI., and once in haul 103, on Ground XIII., where the bottomdeposit is coarse gravel mixed with mud.

Distribution. Geographical. Finmark to Ëgean (Jeffreys).

Depth. 2-80 fathoms (Jeffreys).

Bottom-deposit. Forbes and Hanley state that Eulima polita frequents sandy bottoms. Forbes (Brit. Assoc., 1850) gives seven records from coarse ground (shell, nullipore, gravel, etc.) and two from sand. Gwyn Jeffreys says it is found on muddy sand. Metzger (No. 77) records it once on stony ground.

Natica nitida (=N. Alderi of Jeffreys). One specimen only in haul 46, on Ground XI., bottom coarse gravel with fine sand.

Distribution. Geographical. Lofoten Islands to Mediterranean (Jeffreys, No. 55).

Depth. Low-water to 135 fathoms (Locard, No. 69).

Bottom-deposit. Forbes (No. 24, Brit. Assoc., 1850) gives thirteen records from coarse ground, five from sand, three from mud. Gwyn Jeffreys says it occurs everywhere in sand. Metzger (No. 77) gives eleven records on coarse ground, twelve on sand, fine sand, or sandy mud. It appears, therefore, that the species frequents coarse and fine ground about equally.

Lamellaria perspicua. A few specimens of this species were obtained on Grounds VII. and XI. in the neighbourhood of the Eddystone and on the Bolt Head shell gravel (XVII.). It is generally found crawling on hydroids.

Distribution. Geographical. Norway to Azores, Madeira, and Mediterranean. Also Canadian and United States Atlantic Coasts (Jeffreys).

Depth. Low-water to 704 fathoms (Dauzenberg, No. 20).

Bottom-deposit. Most abundant on sea-weeds, etc., in tidal and laminarian zones.

Nassa incrassata. This was taken alive on the Prawle Stony Ground (XVIII.).

Distribution. Geographical. Iceland to Azores and Mediterranean (Jeffreys).

Depth. Low-water to 145 fathoms.

Bottom-deposit. The authors agree that the species frequents stony ground, especially in the tidal and laminarian zones.

Buccinum undatum (Chart XV.). The common whelk was numerous on the gravel and coarser sand grounds in the neighbourhood of the Eddystone and on the Bolt Head Shell Gravel. It was entirely absent from the fine sand of the outer and inner trawling grounds, and was only taken once on the Prawle Stony Ground (haul 45).

As will be seen from Chart XV., the species was absent also from the clean shell gravel close to the Eddystone rocks (Ground XVI.), and was NEW SERIES.-VOL. v. No. 4. 
very scarce on the fine gravel of Ground XIV. As this latter was a very rich ground, the almost entire absence of whelks is noteworthy.

Distribution. Geographical. Both sides of the North Atlantic from the North Cape and Iceland to Rochelle and Massachusetts. In the stomach of Trigla gurnardus in the Gulf of Lyons (fide Jeffreys).

Depth. Low-water to 180 fathoms (Porcupine, fide No. 33).

Bottom-deposit. Forbes (No. 24, Brit. Assoc., 1850) records Buccinum undatum from all kinds of bottom-deposits, and the other authors agree with this. Heincke (No. 39) says that near Heligoland it is specially common on sandy mud and on pure mud. Petersen (No. 95) found it common all over the Kattegat. The animal is able to burrow in sand (Jeffreys).

Fusus islandicus (=F. gracilis of Jeffreys). Taken only in hauls 105 and 107 on the Bolt Head Shell Gravel, where several living specimens and a number of shells were obtained.

Distribution. Geographical. A northern species. White Sea (?), Russian Lapland, Iceland, Faröe Islands, Norway, Sweden, Kattegat, * British Seas, North of France, LoireInférieure. Rare in the South of England, common on northern fishing banks (Jeffreys).

Depth. 20-145 fathoms (Jeffreys).

Bottom-deposit. Forbes (Brit. Assoc., 1850) found it on shell, on stones, on sandy gravel, and on sand; Metzger on sandy mud, and on sand, shells, and stones.

Cypraea europaea (Table VI.). Not uncommon in the neighbourhood of the Eddystone, on the coarser sand grounds, and on the Prawle Shell Gravel, especially amongst hydroids and Cellaria.

Distribution. Geographical. Drontheim to Gibraltar and Mediterranean (Jeffreys).

Depth. 0-100 fathoms.

Bottom-deposit. Forbes (No. 24, Brit. Assoc., 1850) gives ten records, all on coarse ground, and Gwyn Jeffreys says the species occurs on stony and coral grounds. Metzger (No. 77) gives two records, one on stony ground and one on sand.

Ovula patula (Table VI.). Single specimens were taken on Grounds II., VIII., and XVIII. The species is generally found on Alcyonium digitatum.

Distribution. Geographical. British Coasts, Gulf of Lyons (?) (Jeffreys).

Depth. Coralline zone (Jeffreys).

Bottom-deposit. On Alcyonium (Forbes and Hanley).

Dondersia banyulensis, Pruvot. A few specimens of this species, which is very conspicuous owing to its bright red colour, were obtained always upon colonies of Lafoea dumosa. It is recorded on Grounds III., IV., and X.

The species was first described by Pruvot (No. 97), who found it always on Lafoea dumosa. It is relatively abundant at Banyuls, in the Mediterranean, in 25-165 fathoms, and a few specimens were obtained at Roscoff, in Brittany, in 44 fathoms.

Proneomenia aglaopheniae (Kowalevsky et Marion). This Neomenian was met with not unfrequently coiled around the stem of Aglaophenia myriophyllum, though it was present on only a small proportion of the total number of specimens of the hydroid which were taken. It is recorded on Grounds III., VII., VIII., XI., XII.

\footnotetext{
* Petersen does not record it. Jeffreys gives it on the authority of Jonas.
} 
Proneomenia aglaopheniae was described by Kowalevsky and Marion (No. 62) from specimens obtained at Marseilles, and has since been taken by Pruvot (No. 97) at Banyuls (33-44 fathoms). In both cases the animal was coiled around the stem of A. myriophyllum. The specimens from the Eddystone Grounds are, so far as I am aware, the only ones which have been taken outside the Mediterranean.

Nudibranchiata (Table VI., p. 533). By far the most numerous nudibranchs taken were Doto fragilis and Lamellidoris oblonga. The former species was abundant on grounds where hydroids were plentiful, especially on the coarse gravels to the westward of the Eddystone, where Halecium halecinum was the characteristic species. On the fine sand grounds Doto pinnatifida and Doto coronata, which were not taken on the gravel, were also met with. Lamellidoris oblonga is associated always with Cellaria fistulosa and sinuosa, and is present on the grounds where these species are abundant. (Cf. Garstang, Jour. Mar. Biol. Assoc., III., p. 220.) Occasional specimens only of other nudibranchs were taken, as will be seen from Table VI., and also from the descriptions of the grounds.

Most of the specimens were identified by Mr. W. I. Beaumont. With regard to the geographical distribution of these forms I am unable to add anything to the information given by Norman in his Revision of the Mollusca (No. 91).

\section{PolyzoA.}

For nomenclature and for geographical distribution (Table VI., p. 534) I have relied entirely upon Hincks (History of British Marine Polyzoa). The specimens in several of the earlier hauls were identified by Mr. T. $\mathrm{H}$. Taylor. The distribution of only a very few of the species of Polyzoa on the grounds investigated offers any points of interest.

Cellaria fistulosa and Cellaria sinuosa. Both these species are abundant on the fine sand grounds in the neighbourhood of the Eddystone (Grounds I., III., IV., VI., VIII.), where they form a marked and characteristic feature of the fauna. Whenever the trawl is used on these grounds masses of Cellaria are taken, and the polyzoan, which is attached either to small pieces of shell or directly to the sand by means of its root-fibres, affords a fixing-place for the smaller hydroids (e.g., Clytia Johnstoni) and for the nudibranch Lamellidoris oblonga. At the bases of the colonies the polyzoon Scrupocellaria scruposa is often attached, and very small specimens of Ophiothrix fragilis find a hiding-place. The extreme scarcity of Cellaria on the fine sand of the Outer Trawling Ground (II.) is noteworthy (cf. p. 393), as well as its scarcity on Ground V., to the north of the Eddystone. On the gravels to the westward of 
the Eddystone only occasional pieces of these polyzoa are met with, whilst it has never been taken on the shell gravel grounds. (Chart XVI.)

Scrupocellaria scruposa. After the two species of Cellaria this is the most abundant branched polyzoan. It is plentiful both on the fine sand grounds and on the gravels in the neighbourhood of the Eddystone. It is generally attached to the tubes of polychaetes (e.g., Thelepus, Chaetopterus variopedatus) or to the base of Cellaria. It is rarely met with on the shell gravel grounds and on the Prawle Stony Ground.

Bicellaria ciliata is not unfrequently met with attached to hydroids of various kinds. The most common species of Bugula is B. avicularia, and $B$. flabellata is also occasionally taken. Cellepora avicularis and Cellepora ramulosa are abundant on the fine sand grounds attached to hydroids. Incrusting Polyzoa are plentiful on all grounds where mollusc shells are numerous (see Table VI.).

\section{Tunicata.}

Nomenclature :-Herdman, "Revised Classification of the Tunicata," Journ. Linn. Soc., XXIII., 1891.

In the identification of the Tunicata $I$ have received much help from my colleague, Mr. W. Garstang.

Molgula oculata. Specimens of this species were only occasionally taken, covered in each case with broken shell gravel. They occurred on the clean broken shell of Ground XVI. immediately to the westward of the Eddystone rocks, and on the coarse gravel of Ground XI. to the north-west of the Eddystone. The species is one which is usually taken only on coarse ground.

Molgula simplex. Specimens which we have identified as $M$. simplex occurred somewhat frequently on Chactopterus tubes, though they were not recorded in many of the hauls, owing to their only having been identified at a somewhat late stage in the investigation. The specimens were usually 5 or $6 \mathrm{~mm}$. in diameter. The species probably occurs on all the Chaetopterus grounds.

Forbesella tesselata. One specimen only on the fine gravel ground $\mathrm{XV}$.

Styelopsis grossularia. The small squat variety of this species was not unfrequently met with on shells, especially Pecten shells, on the gravels to the westward of the Eddystone and on the Bolt Head Shell Gravel.

Polycarpa varians, Heller $=(P$. pomaria, Sav. $)$. This species is very much restricted to one area, west and south-west of the Eddystone, where, however, it is abundant, and forms a striking and characteristic feature of the fauna. It is very abundant on Grounds IX. and XIV., on both of which the bottom-deposit is gravel, and also on those hauls 
on Ground X. which are not entirely occupied by Ophiothrix fragilis. The species extends south of these grounds to Ground VII., where in some hauls it is still moderately plentiful. On the gravel to the north-west of the Eddystone (Ground XI.) specimens were taken only in haul 47, whilst on the gravel to the south-west (Ground XIII.) only one or two very small ones were seen, although on both these grounds the general fauna is very similar to that of Ground IX. The specimens were found in most cases attached directly to the gravel, with which their bases were covered when they came up, but were sometimes also attached to shells.

The only other record of the species was of two small specimens attached to a shell in haul 92 on the fine sand of Ground I., so that it may be regarded as practically absent from all fine sand grounds, as well as from the Bolt Head and Prawle Grounds. (Chart XVI.)

Ascidiella venosa. Occasional specimens only were taken. These were on Grounds IV., XI., and XVI.

Ascidiella scabra. Although some specimens of $A$. scabra have been met with on almost every ground examined, when the question of abundance is considered it is found that the species has a very definite and characteristic distribution. It occurs in greatest abundance on the fine sand grounds, being specially numerous where the hydroid Sertularella Gayi is plentiful, its favourite situation being at the base of the stem of the hydroid. On the coarse grounds near the Eddystone, where Sertularella seldom occurs, specimens of Ascidiella scabra are only rarely seen, and are then attached either to shells, to the tubes of Chaetopterus, or on the backs of Inachus dorsettensis. On the Bolt Head Shell Gravel one or two were seen in hauls 20 -and 107 only, and the species was never taken on the Prawle Stony Ground. (Chart XVI.)

Ascidia depressa (Garstang, Journ. Mar. Biol. Assoc., Vol. II., p. 125). Not uncommon on the Bolt Head Shell Gravel, attached to shells. With the exception of an occasional specimen on the Prawle Stony Ground the species was not elsewhere taken.

Ascidia mentula. Taken once on the Bolt Head Shell Gravel.

Ciona intestinalis. Occasional specimens attached to shells on Grounds II., VII., XIV., XVII., and XVIII., being most frequent on XVII., the Bolt Head Shell Gravel.

Compound Ascidians. These have not been identified. A species of Botryllus was not uncommon, and a Didemnid was plentiful on Cellaria.

\section{Fishes.}

As the trawl was only used on a few of the grounds, the list of fishes is very incomplete. I shall enter into no discussion on the subject of their distribution, as my colleague, Mr. Holt, is engaged in a study of 
the distribution of the fishes on all the grounds in the Plymouth district, and those met with in the present investigation, which were for the most part identified by him, will be included in his general account.

For the Geographical Distribution, as given in Table VI., I have relied on Smitt's Scandinavian Fishes and on Günther's British Museum Catalogue.

\section{SECTION VII. \\ GENERAL CONSIDERATIONS.}

The Association of Species with one Another. In the descriptions of the grounds investigated, as well as in the accounts of the distribution of individual species, numerous instances of the definite association of one species with another have been pointed out. Many of these are examples of the kind of association which is already well known, e.g., Sagartia parasitica with Eupagurus Bernhardus, Adamsia palliata with Eupagurus Prideauxii, Montacuta substriata with Spatangus purpureus, etc. Others, such as the frequent association in one group of Thelepus sp., Sertularella Gayi, Ascidiella scabra, and Sabella (pavonina?) (cf. p. 390), or of Chaetopterus variopedatus, Halecium halecinum, Plumularia Catharina, etc. (p. 414), have not been previously described in detail, and are probably of a less definite nature. It will be of interest and importance not only to compare such groups with those found in other localities, but also to compare the whole fauna found upon similar bottom-deposits in different districts. Unfortunately the published data upon which any such comparison can be founded are neither numerous nor altogether satisfactory. The most promising reports from which the general nature of the fauna at particular spots can be ascertained are those giving the results of the dredgings and trawlings of the German expedition in the Pommerania, which worked in the North Sea in 1872 and 1873. In these the numbers of the stations at which each species was obtained are given, and by working through the reports of the specialists in each group one can compile a list of the fauna at any particular station. Unfortunately there is a good deal of internal evidence to indicate that, in the case of the more common species especially, the list of stations at which each was taken is by no means complete, and the lists of the fauna obtained at particular stations derived from the reports are, therefore, not as perfect as could be desired, nor can one be sure that the common and prevailing species are mentioned.

I give below the lists for five stations where the fauna was evidently in many ways similar to that found on some of the Eddystone Grounds. 
Such indications as the reports afford, as to which were the abundant and characteristic species, are also mentioned, but in this respect the information is very imperfect. There are few indications as to the attachments of fixed species, and it is not made clear in most cases which species were definitely associated with each other. This was almost inevitable in the case of an expedition covering a very large area, and when the animals belonging to different groups were divided amongst a number of specialists not in immediate communication with each other. In the case of the Eddystone to Start Grounds, described in the present report, where the area dealt with is limited, and where the species have nearly all been identified in the same laboratory, it has been much more easy for one individual to obtain some knowledge of the whole fauna and co-ordinate the different groups. I must, however, emphasise the fact that lists of the species found upon a ground are of very little service in giving an idea of the character of its fauna unless information is added as to the relative abundance of each animal, and so far as possible as to its relations with other organisms and with the bottom-deposit.

Comparison with North Sea and Irish Sea Faunas. Lists of the fauna at five stations dredged by the Pommerania expedition in the North Sea, compiled from the reports of the expedition:-

Station 111.

Pommerania Expedition, August 20th, 1872.

9 a.m. $1 \frac{1}{2}$ miles E.S.E. of Lowestoft.

Depth, 16 fathoms; Bottom-deposit, Small stones.

[ $\mathrm{M}=$ many $; \mathrm{P}=$ present in moderate numbers $; \mathrm{F}=$ few. $]$

\section{AotinozoA.}

Alcyonium digitatum

\section{HydrozoA.}

Bimeria vestita

Hydractinia echinata

Tubularia indivisa (M)

Clytia Johnstoni

Campanularia flexuosa

Calycella syringa

Filellum serpens

Halecium halecinum (M)

Sertularella polyzonias

Diphasia attenuata

Sertularia abietina (M)

$$
\text { , argentea (M) }
$$

Hydrallmania falcata (M)

Antennularia antennina (M)

Plumularia setacea

\section{Polychaeta.}

Thelepus cincinatus (M)

Sabellaria alveolata (M)

Sabella penicillus (F)

(=S. pavonina)

Polynoe squamata (F)

Nereis pelagica ( $P$ )

Nephthys caeca (M)

\section{Crustacea.}

Dryope crenatipalmata Amathilla Sabinei Mysis inermis

Gastrosaceus sanctus

Pandalus annulicornis

Virbius fasciger

Porcellana longicornis

Stenorhynchus rostratus (=S. phalangium)
Mollusca.

Pecten varius (var, alba)

Modiola modiolus

Natica Alderi $(=N$. nitida $)$

Murex erinaceus

Pleurotoma rufa

Doto fragilis

Doris tuberculata ,, pilosa

Thecacera pennigera

\section{PolyzoA.}

Bugula plumosa

Flustra foliacea

Alcyonidium gelatinosum

Lepralia annulata

Tunicata.

Phallusia virginea $(=$ Ascidiella virginea $)$ 


\section{Station 83.}

Pommerania Expedition, August 7th, 1872.

3 p.m. $1 \frac{1}{4}$ miles E.S.E. of Peterhead.

Depth, 30 fathoms ; Bottom-deposit, Sand, with shells and small stones.

Echinodermata.

Ophioglypha affinis (P)

Ophiopholis aculeata (P)

Luidia Savignyi (P)

Astropecten Mülleri (F) $(=A$. irregularis $)$

Echinocardium flavescens (F) Spatangus purpureus (see p. 235)

Strongylocentrotus droebachiensis (M)

\section{HYDROZOA.}

Hydractinia echinata

Tubularia indivisa

" $\quad \operatorname{larynx}(\mathrm{M})$

Clytia Johnstoni

Campanularia flexuosa

Cuspidella grandis

Halecium halecinum

,, Beanii

Sertularella polyzonias

Diphasia rosacea

,, tamarisca
Sertularia abietina (M) ,, argentea (M)

Hydrallmania falcata (M)

Thuiaria thuia

, articulata

Antennularia ramosa (M)

Plumularia pinnata

$$
\text { , Catharina }
$$

, echinulata

Polychaeta.

Polynoe cirrata (P)

Glycera capitata (F)

Crustacea.

Anceus maxillaris

Areturus longicornis

Hyas coarctatus

\section{Mollusca.}

Anomia ephippium

Pecten sinuosus

," Islandicus Shell

, tigrinus $\int$ only

,, Testae
Modiola modiolus

Montacuta substriata

Astarte sulcata

Venus fasciata

,, casina

", ovata

Tapes edulis (=T. virginea)

Lucinopsis undata

Tellina crassa

Psammobia ferroensis

Mactra solida

Chiton albus

Puncturella Noachina

Trochus tumidus ,, millegranus (one shell)

Turritella ungulina

$$
\text { (=T. communis) }
$$

Natica Alderi $(=N$. nitida)

Fusus antiquus

,, gracilis

$$
(=F . \text { islandicus })
$$

Eolis aurantiaca

Tritonia plebeia

\section{Station 85.}

Pommerania Expedition, August 8th, 1872.

Firth of Forth, E.N.E. of Isle of May.

Depth, 30 fathoms; Bottom-deposit, Coarse sand and stones.

Echinodermata.

Asteracanthion rubens (F) (=Asterias rubens)

HYDROZOA.

Perigonimus repens (on Turritella)

Hydractinia echinata

Tubularia larynx (M)

Clytia Johnstoni

Halecium halecinum

Diphasia rosacea

Sertularia argentea (M)

Hydrallmania falcata (M)

Thuiaria thuia
Antennularia ramosa (M)

Plumularia pinnata

$$
\text { , Catharina }
$$

\section{Polychaeta.}

Thelepus cincinnatus

\section{Crustacea.}

Callisoma Kröyeri

\section{Mollusca.}

Turritella ungulina (=T. communis)

Fusus antiquus
Fusus gracilis

$$
\text { ( }=F . \text { islandicus })
$$

,, propinquus

,, Jeffreysianus

Eolis Drummondii

Tritonia Hombergii

Polyzoa,

Alcyonidium hirsutum

",

parasiticum

Tunicata.

Phallusia virginea

(=Ascidiella virginea) 
Station 115.

Pommerania Expedition, August 20th, 1872.

$2^{\circ} 50^{\prime} \mathrm{N} .52^{\circ} 22^{\prime} \mathrm{N}$.

Depth, 23 fathoms; Bottom-deposit, Sticky blue-grey mud with shells.

ActinozoA.

Sagartia troglodytes

,, parasitica on Buccinum

HYDROZOA.

Hydractinia echinata

Tubularia indivisa

Obelia dichotoma

Campanularia verticillata

Filellum serpens

Halecium halecinum

Sertularella polyzonias
Diphasia attenuata
Sertularia argentea
Hydrallmania falcata
Antennularia antennina
Plumularia setacea
MolluscA.
Pecten varius
, opercularis (var. lin-
eata, abundant)
Arca lactea, shell

Venus gallina

Donax vittatus

Syndosmya prismatica

Cultellus pellucidus

Ensis (Solen) ensis-Young?

Buccinum sp. (see p. 140)

\section{PolyzoA.}

Flustra truncata (=F. securifrons, Pallas) Membranipora pilosa

\section{Station 84.}

Pommerania Expedition, August 7th, 1872.

7 p.m. $3 \frac{1}{2}$ miles S.E. of Peterhead.

Depth, 50 fathoms; Bottom-deposit, Sand and shells.

$[\mathrm{M}=$ many $; \mathrm{P}=$ present in moderate numbers $; \mathrm{F}=$ few. $]$

\section{Porifera,}

Suberites domuncula

\section{Echinodermata.}

Ophioglypha texturata (P) (=Ophiura ciliaris)

Luidia Savignyi (P)

Solaster endeca (P)

Echinus miliaris (M) , acutus (P)

Strongylocentrotus droebrachiensis ( $\mathrm{P}$ )

\section{HYDROZOA.}

Tubularia indivisa

$$
\text { , } \operatorname{larynx}(\mathrm{M})
$$

Clytia Johnstoni

Campanularia flexuosa

Lafoea dumosa

Calycella syringa

Filellum serpens

Coppinia arcta on Hydrallmania falcata

Diphasia rosacea

Sertularia abietina (M)

\begin{tabular}{l} 
Hydrallmania falcata (M) \\
Thuiaria thuia \\
Antennularia ramosa (M) \\
Plumularia pinnata \\
\multicolumn{1}{c}{ PoLycHAETA. } \\
Eumenia crassa (F) \\
Thelepus cincinnatus (M) \\
Pectinaria auricoma (P) \\
Sabellaria alveolata (M) \\
Protula protensa (M) \\
$\quad$ (=P. tubularia) \\
Filograna implexa (M) \\
Hydroides norvegica (M) \\
Aphrodite aculeata (P) \\
Polynoë cirrata (F) \\
$\quad$ squamata (F) \\
Lumbriconereis fragilis (F) \\
Nereis pelagica (F) \\
Phyllodoce maculata (F) \\
CrustacEA. \\
Naenia rimapalmata \\
Megamoera semiserrata \\
Mysis ornata
\end{tabular}

Pandalus annulicornis

Hippolyte Lilljeborgi

Crangon Allmani

Galathea squamifera

Pagurus Bernhardus

, pubescens

Inachus dorsettensis

Hyas coarctatus

Stenorhynchus rostratus (=S. phalangium)

Atelecyclus septemdentatus ( $=$ A, heterodon $)$

\section{Mollusca.}

Stilifer Turtoni

Fusus gracilis

(=F. islandicus, F. \& H.).

PolyzoA.

Gemellaria loricata

Flustra foliacea

Crisia eburnea

Tunicata.

Ciona intestinalis

The first four of these hauls appear to have been made on grounds similar in many respects to the Eddystone Gravel Grounds and to 
the Prawle Stony Ground. The fifth (Sta. 84) was clearly on a fine sand ground with shells, similar to the sand bordering the Eddystone gravels. Imperfect as the lists doubtless are, one cannot but be struck by the fact that on the whole we are dealing with the same species as those found on the grounds examined during the present investigation, arranged possibly in a somewhat different manner, with a few forms added and a few taken away.

Some of the more striking differences may be pointed out, in order to indicate the nature of the information which one would wish future investigators to supply when dredging in similar localities. The constant abundance of Tubularia indivisa and Tubularia larynx, both on the coarse and fine grounds in these North Sea hauls, is noteworthy. Fragments only of $T$. indivisa were obtained on the Eddystone to Start Grounds (viz., on the Prawle Stony Ground, attached to a large stone), and so far as our experience goes the species in this neighbourhood is confined to rocky situations. A knowledge of the exact conditions on the North Sea Grounds, and of the kind of material to which the hydroid is generally attached," might throw light upon this difference.

Halecium halecinum is present and sometimes abundant on each of the coarse North Sea Grounds, whilst it is absent from the sand. This is similar to its distribution on the Eddystone Grounds, but on these latter it is in by far the larger number of cases attached to the tubes of Chactopterus, a species which is not recorded in the Pommerania reports. Schulze makes the general statement that $H$. halecinum was attached to shells, worm tubes, etc., but there is no indication as to whether any particular worm takes the place which Chaetopterus occupies on the Eddystone Grounds.

Amongst the Crustacea one may notice that in the North Sea hauls Stenorhynchus rostratus ( $=S$. phalangium) takes the place of $S$. longirostris, and that, as on the Eddystone Grounds, Stenorhynchus and Inachus are present on the fine grounds, but rare or absent on the coarse.

The almost entire absence of Pecten opercularis and the entire absence of $P$. maximus on these particular North Sea Grounds is noteworthy, and there is no species which obviously takes the place which they occupy on the corresponding Eddystone Grounds. On the other hand Fusus antiquus on the North Sea Grounds seems to take the place of Buccinum undatum on the Eddystone Grounds. A similar change of a striking nature (confirmed by other hauls of the Pommerania) is the fact that Flustra foliacea seems to exactly take the place usually occupied by Cellaria fistulosa and sinuosa in the neighbourhood of Plymouth.

* T. larynx is stated by Schulze to be attached to shells and to other hydroids, e.g., Tubularia indivisa. No statement is made as to the attachment of the latter species. 
Differences of this kind are of very great interest, but our knowledge of them is far too slight at the present time to make any satisfactory explanation possible.

In the Presidential Address to the Biological Section of the British Association, at the Ipswich meeting, Herdman gives a list of the species obtained in a single haul of a trawl in the Irish Sea. (Rep. Brit. Assn., 1895, p. 713.) This haul was recorded in order to find the number of species and genera represented on the ground, and unfortunately no information is given as to the relative abundance of each species. It is therefore impossible to get a good idea of the characteristic nature of the fauna on the ground. On the whole it resembles that found on the grounds to the west of the Eddystone, both the gravel and fine sand faunas being represented. It is of interest to note that Chaetopterus and Halecium halecinum are both recorded and that Fusus antiquus is present, whilst Buccinum undatum is absent.

In the Proceedings of the Liverpool Biological Society (No. 40) Herdman also records several grounds where ophiurids occur to the almost entire exclusion of other species, a condition of things similar to that occurring on Ground X., to the west of the Eddystone ( $c f$. pp. 416 and 499).

Geographical Distribution. Following Michaelsen (No. 79), three of Forbes' geographical provinces have been recognised, under the names Arctic, Boreal, and Lusitanian. The Boreal province contains the greater part of Forbes' Celtic. The Arctic province (A.) Michaelsen regards as bounded on the south by a line commencing at Cape Race in Newfoundland, running parallel to the south-east coast of Greenland, cutting off the north corner of Iceland, and then striking the Scandinavian coast at the Lofoten Islands. The Boreal province (B.) lies south of this line, and comprises the temperate portion of the east coast of North America, the greater part of Iceland, the greater part of the Scandinavian Coast, the North Sea and the Baltic, and the British Seas with the exception of the south coast. The Lusitanian province (L.) extends from the English Channel to the Canaries and Azores, and includes the Mediterranean.

- In Table VI., p. 529, the distribution of each species in the three provinces has been indicated by the letters A. B. and L. Our knowledge of the true centres of distribution of the species is still too imperfect in the majority of cases to make it possible to say whether a species which is found in two provinces is equally at home in both, or whether its centre of distribution occurs in one of the provinces and the species must be regarded merely as an immigrant into the other.

Species extending from the Arctic Seas to the Mediterranean, Azores, and Canary Islands are indicated by the letters A.L.; those which are found in the Arctic and extend throughout the Boreal region by A.B.; 
whilst those which have only been recorded from the Boreal by B. The letters L.B. denote species extending from the Mediterranean to the north of Norway, Iceland, and often to the eastern coast of America. The letter L. indicates that the species has its centre of distribution in the Lusitanian province, but such species may extend up the western coasts of the British Isles to Shetland, or even to the southern parts of Scandinavia.

In Table VII., p. 536, the total number of species falling under each of these heads is given for the various groups of animals obtained during the present investigation, all of which, therefore, live at a depth of about 30 fathoms between Start Point and the Eddystone. In each case also the percentage of animals belonging to the group, living in each region, is added.

Regarding this fauna as a whole, it will be seen that the prevailing element is southern, or Lusitanian; 56 per cent. falling under the heads of L. and L.B., and 30 per cent. under L. alone, whilst only 26 per cent. come under A.B. and B. Eight per cent. of the recorded species occur in the Arctic and Boreal regions only, whilst 18 per cent. have a very wide range, extending from the Arctic to the Mediterranean.

Looking at the figures for each group (excluding those in which the number of species is too small to give reliable results), it may be noticed that the fishes and Crustacea show the southern element most markedly, whilst the Hydrozoa and Polyzoa are remarkable for the number of species which have a very extended range.

In a subsequent paper I hope to compare the figures obtained for species living at 30 fathoms with similar ones for species extending from the shore to about 15 fathoms. 


\section{Table I. List of Hauls.}

The entries under the head of "Nature of bottom" in this table are in most cases the notes made on board the vessel at the time the dredge came on deck.

\begin{tabular}{|c|c|c|c|c|c|c|}
\hline $\begin{array}{l}\text { No. of } \\
\text { haul. }\end{array}$ & Date. & $\begin{array}{l}\text { No. of } \\
\text { ground. }\end{array}$ & Locality. & $\begin{array}{l}\text { Direction } \\
\text { towed. }\end{array}$ & Nature of bottom. Ins & $\begin{array}{l}\text { istrument } \\
\text { used. }\end{array}$ \\
\hline 1 & $\begin{array}{l}\text { July } 30 \\
1895\end{array}$ & XVII. & $\begin{array}{l}\text { Prawle Point, bearing } N \text {. } \\
\text { by E., } 2 \frac{1}{2} \text { miles off }\end{array}$ & S. by E. & $\begin{array}{l}\text { Coarse gravel and } \\
\text { shells }\end{array}$ & Dredge \\
\hline 2 & $\begin{array}{l}\text { July } 30 \\
\quad 1895\end{array}$ & XVIII. & $\begin{array}{l}\text { Prawle, bearing N., } \\
3 \text { miles off }\end{array}$ & S. by E. & Rocks. Trawl fast & $\begin{array}{l}\text { Otter } \\
\text { Trawl }\end{array}$ \\
\hline 3 & $\begin{array}{l}\text { July } 30 \\
\quad 1895\end{array}$ & XVIII. & $\begin{array}{l}\text { Prawle Point, N. by W., } \\
3 \text { miles off }\end{array}$ & S. by E. & $\begin{array}{l}\text { Stones or rocks. } \\
\text { Trawl torn }\end{array}$ & $\begin{array}{l}\text { Otter } \\
\text { Trawl }\end{array}$ \\
\hline 4 & $\begin{array}{l}\text { July } 30 \\
1895\end{array}$ & XVIII. & $\begin{array}{l}\text { Prawle, N. by W., } 4 \frac{1}{2}-5 \\
\text { miles }\end{array}$ & S. by E. & $\begin{array}{l}\text { Broken shells and } \\
\text { stones }\end{array}$ & Dredge \\
\hline 6 & $\begin{array}{l}\text { Aug. 2, } \\
1895\end{array}$ & XVII. & Bolt Head, N., 5 miles & Easterly & Broken shell & Dredge \\
\hline 7 & $\begin{array}{l}\text { Aug. } 2 \text {, } \\
1895\end{array}$ & XVII. & $\begin{array}{l}\text { Bolt Head, N. by W., } \\
5 \text { miles }\end{array}$ & Easterly & $\begin{array}{l}\text { Broken shell and } \\
\text { some gravel }\end{array}$ & Dredge \\
\hline 8 & $\begin{array}{l}\text { Aug. 16, } \\
1895\end{array}$ & XI. & $\begin{array}{l}\text { Eddystone, bearing S.E. } \\
\frac{1}{2} \text { S., } 3 \text { miles off }\end{array}$ & S.E. $\frac{1}{2} \mathrm{~S}$. & Gravel and shells & Dredge \\
\hline 9 & $\underset{1895}{\text { Aug. }}$ & XI. & $\begin{array}{l}\text { Eddystone, bearing S.E. } \\
\frac{1}{2} \text { S., } 2 \frac{1}{2} \text { miles off }\end{array}$ & S.E. $\frac{1}{2} \mathrm{~S}$. & $\begin{array}{l}\text { Gravel finer than } \\
\text { in } 8\end{array}$ & Dredge \\
\hline 10 & $\underset{1895}{\text { Aug. } 16}$ & XVI. & $\begin{array}{l}\text { Eddystone, S.E. } \frac{1}{2} \text { S., } \\
\frac{1}{2} \text { mile }\end{array}$ & $\cdots$ & $\begin{array}{l}\text { Fine, clean broken } \\
\text { shell }\end{array}$ & Dredge \\
\hline 13 & $\underset{1895}{\text { Aug. } 16,}$ & XVI. & $\begin{array}{l}\text { Eddystone, E. } \frac{1}{2} \text { N., } \\
\frac{1}{2} \text { mile }\end{array}$ & $\cdots$ & $\begin{array}{l}\text { Fine broken shell, } \\
\text { some large shells }\end{array}$ & Dredge \\
\hline 14 & $\underset{1895}{\text { Aug. } 16,}$ & XVI. & Eddystone, N., 1 mile & $\cdots$ & $\begin{array}{l}\text { Bottom similar, } \\
\text { shells brokeninto } \\
\text { finer pieces, and } \\
\text { with some mud }\end{array}$ & Dredge \\
\hline 20 & $\underset{1895}{\text { Aug. 31, }}$ & XVII. & $\begin{array}{l}\text { Bolt Tail, N.N.E., } \\
3 \text { miles off }\end{array}$ & $\cdots$ & $\begin{array}{l}\text { Stones, shells, and } \\
\text { gravel }\end{array}$ & Dredge \\
\hline 21 & $\underset{1895}{\text { Aug. 31, }}$ & XVII. & $\begin{array}{l}\text { Bolt Head, N.E. by N., } \\
1 \text { mile off }\end{array}$ & $\cdots$ & $\begin{array}{l}\text { Broken shell witha } \\
\text { few small stones }\end{array}$ & Dredge \\
\hline 22 & $\underset{1895}{\text { Aug. 31, }}$ & II. & $\begin{array}{l}10 \text { miles S. of Plymouth } \\
\text { Mewstone }\end{array}$ & $\cdots$ & Fine sand & $\begin{array}{l}\text { Otter } \\
\text { Trawl }\end{array}$ \\
\hline 23 & $\begin{array}{l}\text { Sept. 9, } \\
1895\end{array}$ & II. & $\begin{array}{l}12 \text { miles S. by W. of } \\
\text { Plymouth Mewstone }\end{array}$ & W. & Fine sand & $\begin{array}{l}\text { Otter } \\
\text { Trawl }\end{array}$ \\
\hline 24 & $\begin{array}{l}\text { Sept. } 9 \\
1895\end{array}$ & II. & $\begin{array}{l}\text { Eddystone, bearing N.W., } \\
6 \text { miles (? weather foggy) }\end{array}$ & W. & Fine sand & $\begin{array}{l}\text { Otter } \\
\text { Trawl }\end{array}$ \\
\hline 25 & $\begin{array}{l}\text { Sept. 9, } \\
1895\end{array}$ & II. & End of last haul & W. & Fine sand & Dredge \\
\hline 27 & $\begin{array}{l}\text { Sept. 17, } \\
1895\end{array}$ & XVII. & Prawle, N., 4-5 miles & S.W. & $\begin{array}{l}\text { Shells, broken shells, } \\
\text { gravel, and sand }\end{array}$ & Dredge \\
\hline 28 & $\begin{array}{l}\text { Sept. } 17 \\
1895\end{array}$ & XVII. & 1 mile $W$. of haul 27 & W. & $\begin{array}{l}\text { Shells, brokenshells, } \\
\text { gravel. Not so } \\
\text { much sand and } \\
\text { mud as } 27\end{array}$ & Dredge \\
\hline 29 & $\begin{array}{l}\text { Sept. 17, } \\
\text { 1895 }\end{array}$ & XVIII. & $\begin{array}{l}\text { Prawle, bearing N.W. } \\
\text { Start, bearing N.E. by N. }\end{array}$ & E. & $\begin{array}{l}\text { Largered stone, loose } \\
\text { stones, gravel and } \\
\text { broken shell }\end{array}$ & Dredge \\
\hline 30 & $\begin{array}{l}\text { Sept. 17, } \\
1895\end{array}$ & XVIII. & $\begin{array}{l}\text { Prawle, W.N.W. } \\
\text { Start, N.N.E. }\end{array}$ & E. & $\begin{array}{l}\text { Large stone, many } \\
\text { medium and small } \\
\text { stones. Gravel }\end{array}$ & Dredge \\
\hline 31 & $\begin{array}{l}\text { Sept. 26, } \\
1895\end{array}$ & & $\begin{array}{l}\text { Eddystone, N. by E., } \\
1-1 \frac{1}{2} \text { miles }\end{array}$ & S. by W. & $\begin{array}{l}\text { Rocky ground. } \\
\text { Dredge broken }\end{array}$ & Dredge \\
\hline
\end{tabular}




\begin{tabular}{|c|c|c|c|c|c|c|}
\hline $\begin{array}{l}\text { No. of } \\
\text { haul. }\end{array}$ & Date. & $\begin{array}{l}\text { No. of } \\
\text { ground. }\end{array}$ & Locality. & $\begin{array}{l}\text { Direction } \\
\text { towed. }\end{array}$ & Nature of bottom. & $\begin{array}{l}\text { Instrument } \\
\text { used. }\end{array}$ \\
\hline 32 & $\begin{array}{l}\text { Sept. } 26 \\
1895\end{array}$ & VII. & $\begin{array}{l}\text { Eddystone, N. } \frac{1}{2} \text { W., } \\
1 \frac{1}{2} \text { miles }\end{array}$ & S.W. & $\begin{array}{l}\text { Stones. } \\
\text { Rough ground }\end{array}$ & Dredge \\
\hline 33 & $\begin{array}{l}\text { Sept. } 26, \\
1895\end{array}$ & XV. & $\begin{array}{l}\text { Eddystone, N.W., } \\
2 \text { miles }\end{array}$ & S.W. & $\ldots$ & Dredge \\
\hline 34 & $\begin{array}{l}\text { Sept. 26, } \\
1895\end{array}$ & IV. & $\begin{array}{l}\text { Eddystone, W. by } \mathrm{S} \text {, } \\
3 \text { miles }\end{array}$ & W. by S. & Sand & $\begin{array}{l}\text { Otter } \\
\text { Trawl }\end{array}$ \\
\hline 35 & $\begin{array}{l}\text { Sept. } 30, \\
1895\end{array}$ & XIV. & $\begin{array}{l}\text { Eddystone, E. } \frac{1}{2} \mathrm{~N} . \text {, } \\
\frac{3}{4} \text { mile }\end{array}$ & S.W. & $\begin{array}{l}\text { Broken shell and a } \\
\text { little gravel }\end{array}$ & Dredge \\
\hline 36 & $\begin{array}{l}\text { Sept. 30, } \\
1895\end{array}$ & XIV. & $\begin{array}{l}\text { Eddystone, E. } \frac{1}{2} \mathrm{~N} . \text {, } \\
\frac{3}{4} \text { mile }\end{array}$ & S.W. & $\begin{array}{l}\text { Broken shell and a } \\
\text { little gravel }\end{array}$ & $\begin{array}{l}\text { Otter } \\
\text { Trawl }\end{array}$ \\
\hline 38 & $\begin{array}{l}\text { Sept. } 30 \\
1895\end{array}$ & VII. & $\begin{array}{l}\text { Eddystone, N.E., } \\
1 \frac{1}{4} \text { miles }\end{array}$ & S.W. & $\begin{array}{l}\text { A little broken } \\
\text { shell and mud }\end{array}$ & Dredge \\
\hline 39 & $\begin{array}{l}\text { Sept. 30, } \\
1895\end{array}$ & IV. & $\begin{array}{l}\text { Eddystone, W. by S., } \\
3 \text { miles }\end{array}$ & W. & Sand & $\begin{array}{l}\text { Otter } \\
\text { Trawl }\end{array}$ \\
\hline 40 & $\begin{array}{l}\text { Sept. } \\
1895\end{array}$ & IV. & $\begin{array}{l}\text { Eddystone, W. by S., } \\
3 \text { miles }\end{array}$ & W. & mosq & $\begin{array}{l}\text { Fine } \\
\text { quito net }\end{array}$ \\
\hline 41 & $\begin{array}{l}\text { April 7, } \\
1896\end{array}$ & XIV. & $\begin{array}{l}\text { Eddystone, S.E. } \frac{1}{2} \text { S., } \\
1 \frac{1}{2} \text { miles }\end{array}$ & S.E. & Gravel and shells & Dredge \\
\hline 42 & $\begin{array}{l}\text { April 7, } \\
\quad 1896\end{array}$ & $\mathrm{x}$. & $\begin{array}{l}\text { Eddystone, S.E. by E., } \\
2 \frac{1}{2} \text { miles }\end{array}$ & E. & $\begin{array}{l}\text { Gravel, fine sand, } \\
\text { and shells }\end{array}$ & Dredge \\
\hline 43 & $\begin{array}{l}\text { April 8, } \\
\quad 1896\end{array}$ & XVII. & Bolt Head, N., 4 miles & E. & d broken & Dredge \\
\hline 44 & $\begin{array}{l}\text { April 8, } \\
1896\end{array}$ & XVII. & $\begin{array}{l}\text { Prawle, N. by E., } \\
3 \text { miles }\end{array}$ & E. & $\begin{array}{l}\text { coarserthan } \\
\text { and shells }\end{array}$ & Dredge \\
\hline 45 & $\begin{array}{l}\text { April 8, } \\
1896\end{array}$ & CVIII. & $\begin{array}{l}\text { Prawle, N. } \frac{1}{2} \text { W., } \\
\quad 4 \text { miles }\end{array}$ & E. & stones, and & Dredge \\
\hline 46 & $\begin{array}{r}\text { Aug. } 4, \\
1896\end{array}$ & XI. & $\begin{array}{l}\text { Eddystone, S.E. } \frac{1}{2} \text { S., } \\
3 \text { miles }\end{array}$ & S.E. & $\begin{array}{l}\text { gravel, and } \\
\text { sand }\end{array}$ & Dredge \\
\hline 47 & $\begin{array}{l}\text { Aug. 4, } \\
1896\end{array}$ & XI. & $\begin{array}{l}\text { Eddystone, S.E. } \frac{1}{2} \text { S., } \\
2 \text { miles }\end{array}$ & S.E. & Sand (?) & Dredge \\
\hline 48 & $\begin{array}{l}\text { Aug. } 4, \\
1896\end{array}$ & VIII. & $\begin{array}{l}\text { Eddystone, S.E. } \frac{1}{2} \text { S., } \\
1 \text { mile }\end{array}$ & S.E. & Sand and mud & Dredge \\
\hline 49 & $\begin{array}{l}\text { Aug. 4, } \\
1896\end{array}$ & III. & $\begin{array}{l}\text { Eddystone, W. by S., } \\
3 \text { miles }\end{array}$ & E. & Sand & $\begin{array}{l}\text { Otter } \\
\text { Trawl }\end{array}$ \\
\hline 50 & $\begin{array}{l}\text { Aug. } 6 \text {, } \\
1896\end{array}$ & I. & $\begin{array}{l}7 \frac{1}{2} \text { miles (log) S. by E. of } \\
\text { Mewstone Buoy }\end{array}$ & W. by S. & Fine sand & Dredge \\
\hline 51 & $\begin{array}{l}\text { Aug. 6, } \\
1896\end{array}$ & I. & $\begin{array}{l}\text { Eddystone, W. by N. } \\
\frac{1}{2} \text { N., Mewstone, N.N.E. }\end{array}$ & W. by S. & Fine sand & Dredge \\
\hline 53 & $\underset{1896}{\text { Aug. } 20}$ & III. & $\begin{array}{l}\text { Eddystone, S.W. } \frac{1}{2} \mathrm{~S} . \text {, } \\
3 \text { miles }\end{array}$ & W.N.W. & Fine sand & Dredge \\
\hline 54 & $\begin{array}{l}\text { Aug. 20, } \\
1896\end{array}$ & VII. & $\begin{array}{l}\text { Eddystone, N.E., } \\
11_{4}^{\frac{1}{4} \text { miles }}\end{array}$ & W. & Shells and sand & Dredge \\
\hline 55 & $\begin{array}{l}\text { Aug. 20, } \\
1896\end{array}$ & $\mathrm{X}$. & $\begin{array}{l}\text { Eddystone, E. by S. } \frac{1}{2} \text { S., } \\
1 \frac{1}{2} \text { miles }\end{array}$ & W. & $\begin{array}{l}\text { Sand, stones, and } \\
\text { shells }\end{array}$ & Dredge \\
\hline 56 & $\begin{array}{l}\text { Aug. 28, } \\
1896\end{array}$ & III. & $\begin{array}{l}\text { Eddystone, S.W. } \frac{1}{2} \mathrm{~S} \text {, } \\
3 \text { miles }\end{array}$ & E.S.E. & Fine sand & $\begin{array}{l}\text { Beam } \\
\text { Trawl }\end{array}$ \\
\hline 57 & $\begin{array}{l}\text { Aug. } 28, \\
1896\end{array}$ & III. & $\begin{array}{l}\text { Eddystone, W. by N., } \\
4 \text { miles }\end{array}$ & N.N.W. & Fine sand & $\begin{array}{l}\text { Beam } \\
\text { Trawl }\end{array}$ \\
\hline 58 & $\begin{array}{l}\text { Oct. } 21 \text {, } \\
1896\end{array}$ & XIV. & Eddystone, E., 1 mile & W. & $\begin{array}{l}\text { Gravel and broken } \\
\text { shell. Shells }\end{array}$ & Dredge \\
\hline 59 & $\begin{array}{l}\text { Oct. } 21 \\
1896\end{array}$ & XIV. & Eddystone, E., $1 \frac{1}{4}$ miles & W. & $\begin{array}{l}\text { Gravel and broken } \\
\text { shell. Shells }\end{array}$ & Dredge \\
\hline 60 & $\begin{array}{l}\text { Oct. } 1 \\
\quad 1896\end{array}$ & XVII. & Bolt Tail, N.E., 3 miles & S. $\frac{1}{2}$ E. & Sand & Dredge \\
\hline 61 & $\begin{array}{l}\text { Oct. 1, } \\
1896\end{array}$ & XVII. & Bolt Head, N., 2-3 miles & S. $\frac{1}{2} \mathrm{E}$. & Sand and shells & Dredge \\
\hline 62 & $\begin{array}{r}\text { Oct. } 1 \text {, } \\
1896\end{array}$ & XVII. & $\begin{array}{l}\text { Prawle, N.E. by } \\
3 \text { miles }\end{array}$ & S. $\frac{1}{2} \mathrm{E}$. & & Dredge \\
\hline
\end{tabular}




\begin{tabular}{|c|c|c|c|c|c|c|}
\hline $\begin{array}{l}\text { No. of } \\
\text { haul. }\end{array}$ & Date. & $\begin{array}{l}\text { No of } \\
\text { ground. }\end{array}$ & Locality. & $\begin{array}{l}\text { Direction } \\
\text { towed. }\end{array}$ & Nature of bottom. & $\begin{array}{l}\text { Instrument } \\
\text { used. }\end{array}$ \\
\hline 63 & $\begin{array}{r}\text { Oct. } 1 \text {, } \\
1896\end{array}$ & XVIII. & $\begin{array}{l}\text { Prawle, N.N.W. } \frac{1}{2} \text { N., } \\
3 \text { miles }\end{array}$ & S. & Stones and shells & Dredge \\
\hline 64 & $\begin{array}{r}\text { Oct. } 2 \text {, } \\
1896\end{array}$ & XVIII. & $\begin{array}{l}\text { Prawle, N.W. } \frac{1}{2} \text { W., } \\
2-3 \text { miles }\end{array}$ & W. & Stones & Dredge \\
\hline 65 & $\begin{array}{r}\text { Oct. 2, } \\
1896\end{array}$ & XVIII. & $\begin{array}{l}\text { Prawle, N.N.W., } \\
2-3 \text { miles }\end{array}$ & W. & Stones & Dredge \\
\hline 66 & $\begin{array}{r}\text { Oct. } 2 \text {, } \\
1836\end{array}$ & XVIII. & Prawle, N., 3 miles & E. & Stones & Dredge \\
\hline 68 & $\begin{array}{r}\text { Oct. } 2 \\
1896\end{array}$ & XVII. & $\begin{array}{l}\text { Bolt Head, N. by E., } \\
2 \text { miles }\end{array}$ & E. & Shells and gravel & Dredge \\
\hline 69 & $\begin{array}{l}\text { Oct. } 21, \\
1896\end{array}$ & VII. & Eddystone, E., $1 \frac{1}{2}$ miles & W. & Sand & Dredge \\
\hline 70 & $\begin{array}{l}\text { Oct. } 21 \text {, } \\
1896\end{array}$ & VII. & $\begin{array}{l}\text { Eddystone, N.E., } \\
1 \frac{1}{2}-1 \frac{3}{4} \text { miles }\end{array}$ & W. & Sand & Dredge \\
\hline 71 & $\begin{array}{l}\text { Oct. } 21 \text {, } \\
\quad 1896\end{array}$ & VII. & End of last haul & W. & Sand & Dredge \\
\hline 72 & $\begin{array}{l}\text { Sept. 10, } \\
1897\end{array}$ & III. & Eddystone, W., 4 miles & W. by N. & Fine sand & $\begin{array}{l}\text { Beam } \\
\text { Trawl }\end{array}$ \\
\hline 73 & $\begin{array}{l}\text { Sept. } 15, \\
1897\end{array}$ & XIV. & $\begin{array}{l}\text { Eddystone, E. } \frac{3}{4} \text { S., } \\
1 \text { mile }\end{array}$ & W.N.W. & $\ldots$ & $\begin{array}{l}\text { Otter } \\
\text { Trawl }\end{array}$ \\
\hline 74 & $\begin{array}{l}\text { Sept. } 15 \text {, } \\
1897\end{array}$ & XIV. & $\begin{array}{l}\text { Eddystone, E. by S., } \\
1 \text { mile }\end{array}$ & W.N.W. & Gravel and shells & Dredge \\
\hline 75 & $\begin{array}{l}\text { Sept. 15, } \\
\quad 1897\end{array}$ & VII. & $\begin{array}{l}\text { Eddystone, E.N.E., } \\
1 \text { mile }\end{array}$ & W.S.W. & Large stone & Dredge \\
\hline 76 & $\begin{array}{l}\text { Sept. 15, } \\
\quad 1897\end{array}$ & VII. & $\begin{array}{l}\text { Eddystone, N.E. by E., } \\
1 \text { mile }\end{array}$ & W.S.W. & $\begin{array}{l}\text { Gravel and small } \\
\text { shells }\end{array}$ & Dredge \\
\hline 77 & $\begin{array}{l}\text { Sept. 30, } \\
1897\end{array}$ & IV. & $\begin{array}{l}\text { Eddystone, W. by S., } \\
3 \text { miles }\end{array}$ & W. by S. & $\ldots$ & $\begin{array}{l}\text { Beam } \\
\text { Trawl }\end{array}$ \\
\hline 78 & $\begin{array}{l}\text { Sept. 30, } \\
1897\end{array}$ & $\cdots$ & Eddystone, N., 1 mile & $\ldots$ & $\begin{array}{l}\text { Rock. Dredge } \\
\text { empty }\end{array}$ & Dredge \\
\hline 79 & $\begin{array}{l}\text { Sept. 30, } \\
1897\end{array}$ & VII. & A little to west of 78 & $\ldots$ & Red stones, shells & Dredge \\
\hline 80 & $\begin{array}{l}\text { Sept. 30, } \\
\quad 1897\end{array}$ & VII. & $\frac{1}{2}$ mile west of 79 & $\cdots$ & $\begin{array}{l}\text { Clean shells (prob- } \\
\text { ably sand) }\end{array}$ & Dredge \\
\hline 81 & $\begin{array}{l}\text { Oct. 12, } \\
\quad 1897\end{array}$ & I. & $\begin{array}{l}6 \frac{1}{8} \text { miles (log) south of } \\
\text { Mewstone Buoy }\end{array}$ & N.W. & Fine sand & $\begin{array}{l}\text { Beam } \\
\text { Trawl }\end{array}$ \\
\hline 82 & $\begin{array}{l}\text { Oct. 12, } \\
\quad 1897\end{array}$ & I. & 8 miles south of Mewstone & N.W. & Fine sand & $\begin{array}{l}\text { Beam } \\
\text { Trawl }\end{array}$ \\
\hline 83 & $\begin{array}{r}\text { Jan. } 7 \\
\quad 1898\end{array}$ & XII. & $\begin{array}{l}\text { Eddystone, S. by E. } \frac{1}{4} \text { E., } \\
3 \text { miles }\end{array}$ & W.S.W. & $\begin{array}{l}\text { Gravel and sand. } \\
\text { See Table II. 2. C }\end{array}$ & $\begin{array}{l}\text { 1. Dredge } \\
\text { Canvas bag }\end{array}$ \\
\hline 84 & $\begin{array}{r}\text { Jan. } 7 \\
1898\end{array}$ & XI. & $\begin{array}{l}\text { Eddystone, S.E. by S., } \\
2 \frac{1}{4} \text { miles }\end{array}$ & W.S.W. & $\begin{array}{l}\text { Gravel and sand, } \\
\text { cleanerthan } 83 . \\
\text { See Table II. }\end{array}$ & $\begin{array}{l}\text { 1. Dredge } \\
\text { 2. Canvas } \\
\text { bag }\end{array}$ \\
\hline 85 & $\begin{array}{r}\text { Jan. } 7, \\
1898\end{array}$ & XIV. & $\begin{array}{l}\text { Eddystone, S.E. by S., } \\
1 \text { mile }\end{array}$ & W.S.W. & $\begin{array}{l}\text { Fine gravel and } \\
\text { shell. } \\
\text { See Table II. }\end{array}$ & $\begin{array}{l}\text { 1. Canvas } \\
\text { bag } \\
\text { 2. Dredge }\end{array}$ \\
\hline 86 & $\begin{array}{l}\text { Jan. 11, } \\
1898\end{array}$ & XVI. & $\begin{array}{l}\text { Eddystone, S.E. by S., } \\
\frac{1}{2} \text { mile }\end{array}$ & W. & One large stone & Dredge \\
\hline 87 & $\begin{array}{l}\text { Jan. 11, } \\
\quad 1898\end{array}$ & XVI. & $\begin{array}{l}\text { Eddystone, S.E. by S., } \\
\frac{3}{4} \text { mile }\end{array}$ & W. F & $\begin{array}{l}\text { ine broken shell. 1. C } \\
\text { SeeTable II. }\end{array}$ & $\begin{array}{l}\text { Canvas bag } \\
\text { 2. Dredge }\end{array}$ \\
\hline 88 & $\begin{array}{l}\text { Jan. 11, } \\
\quad 1898\end{array}$ & XIV. & Eddystone, E., $\frac{3}{4}$ mile & W. & $\begin{array}{l}\text { Fine broken shell, } \\
\text { with some gravel }\end{array}$ & 1, Dredge \\
\hline 89 & $\begin{array}{l}\text { Jan. 11, } \\
\quad 1898\end{array}$ & $\mathrm{x}$. & $\begin{array}{l}\text { Eddystone, S.E. by S., } \\
1_{2}^{\frac{1}{2}-2} \text { miles }\end{array}$ & N.E. & $?$ & Dredge \\
\hline $89 \mathrm{~B}$ & $\begin{array}{l}\text { Jan. 11, } \\
1898\end{array}$ & VIII. ? & At end of 89 & N.E. & $\begin{array}{l}\text { Fine sand. } \\
\text { See Table II. }\end{array}$ & $\begin{array}{c}\text { Canvas } \\
\text { bag }\end{array}$ \\
\hline 90 & $\begin{array}{l}\text { Jan. 14, } \\
1898\end{array}$ & V. & $\begin{array}{l}\text { Breakwater Light, N.W. } \\
\frac{1}{4} \text { N., } 6 \text { miles }\end{array}$ & E.S.E. & $\begin{array}{l}\text { Fine sand. 1. B } \\
\text { See Table II.2. C }\end{array}$ & am trawe \\
\hline
\end{tabular}




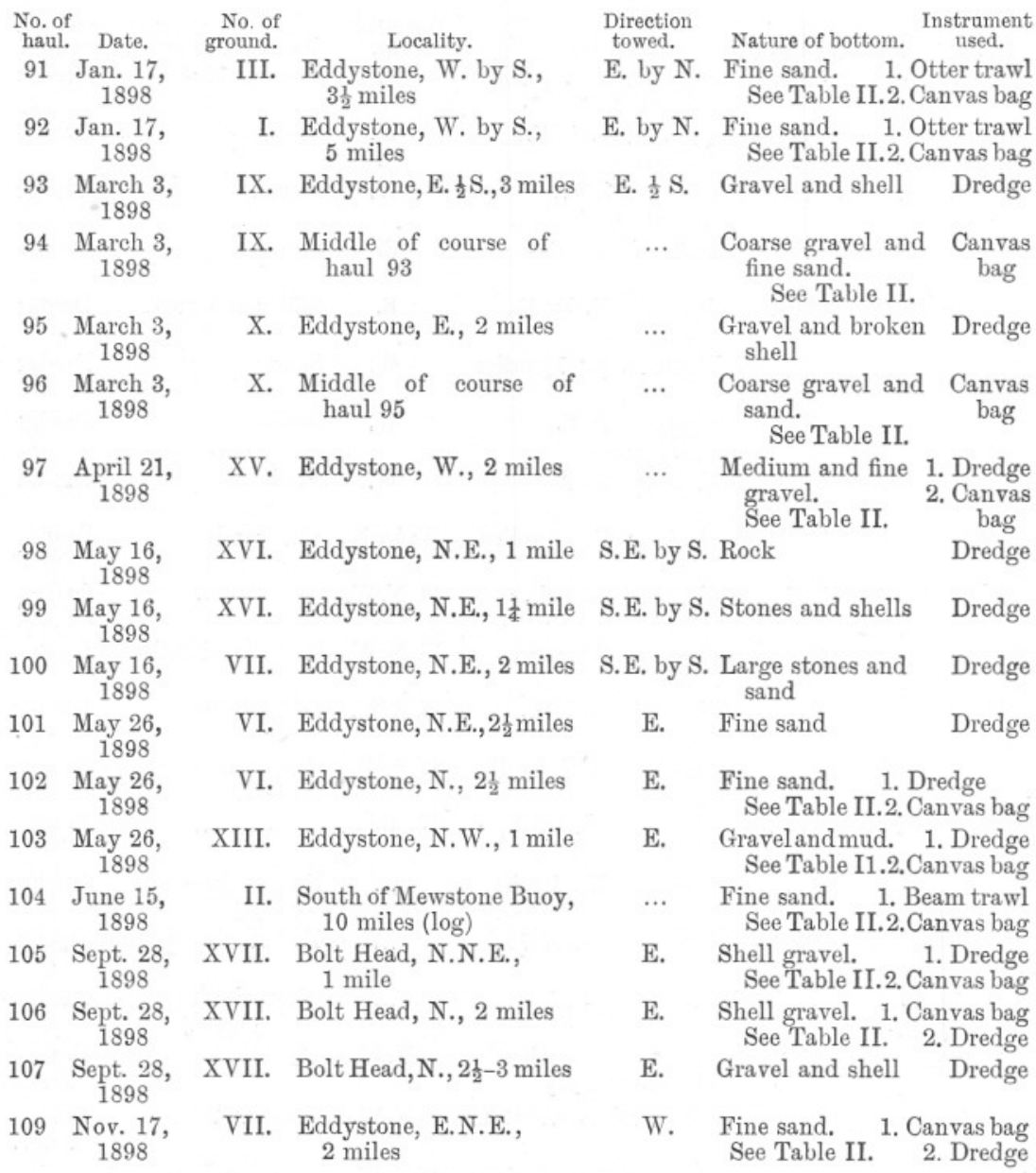


Table II. Texture of Bottom-Deposits.

Showing the percentage weights of each grade of Gravel and Sand found in the samples of bottom-deposit taken from the different grounds.

\begin{tabular}{|c|c|c|c|c|c|c|c|c|c|c|c|c|c|c|c|c|c|c|c|c|}
\hline & \multicolumn{2}{|c|}{ Number of Ground. } & I. & II. & III. & v. & VI. & VII. & VIII. & IX. & $\mathrm{x}$. & XI. & XII. & XIII. & XIV. & xv. & XVI. & \multicolumn{2}{|c|}{ XVII. } & \multirow{2}{*}{$\begin{array}{l}\text { Mud } \\
\text { from } \\
\text { Sound. }\end{array}$} \\
\hline & \multicolumn{2}{|c|}{ Number of Haul. } & 92 & 104 & 91 & 90 & 102 & 109 & $89 \mathrm{~B}$ & 94 & 96 & 84 & 83 & 103 & 85 & 97 & 87 & 105 & 106 & \\
\hline Grade. & & $\begin{array}{l}\text { Size of Mesh } \\
\text { of Sieve. }\end{array}$ & $\%$ & $\%$ & $\%$ & $\%$ & $\%$ & $\%$ & $\%$ & $\%$ & $\%$ & $\%$ & $\%$ & $\%$ & $\%$ & $\%$ & $\%$ & $\%$ & $\%$ & $\%$ \\
\hline I. & Stones & $\begin{array}{r}\text { Left on sieve of } \\
\text { mesh } 15 \mathrm{~mm} \text {. }\end{array}$ & - & - & - & - & - & - & - & 0.9 & - & - & - & - & - & - & - & $1 \cdot 4$ & 0.7 & - \\
\hline II. & $\begin{array}{c}\text { Coarse } \\
\text { Gravel }\end{array}$ & $5 \mathrm{~mm}$. & - & - & - & $2 \cdot 7$ & 0.2 & - & $1 \cdot 3$ & $44 \cdot 4$ & $35 \cdot 3$ & $47 \cdot 6$ & $27 \cdot 9$ & $13 \cdot 4$ & $4 \cdot 1$ & $13 \cdot 4$ & $17 \cdot 3$ & $23 \cdot 1$ & $33 \cdot 8$ & - \\
\hline III. & $\begin{array}{r}\text { Medium } \\
\text { Gravel }\end{array}$ & $2.5 \mathrm{~mm}$. & - & - & - & $2 \cdot 3$ & 0.2 & 0.01 & $1 \cdot 5$ & $14 \cdot 0$ & $14 \cdot 3$ & $14 \cdot 5$ & $28 \cdot 3$ & $29 \cdot 0$ & $17 \cdot 5$ & $20 \cdot 5$ & $31 \cdot 7$ & $15 \cdot 4$ & $18 \cdot 8$ & 0.5 \\
\hline IV. & $\begin{array}{l}\text { Fine } \\
\text { Gravel }\end{array}$ & $1.5 \mathrm{~mm}$. & 0.2 & 0.1 & 0.5 & $2 \cdot 4$ & 0.3 & 0.2 & $2 \cdot 8$ & $10 \cdot 2$ & $9 \cdot 1$ & $7 \cdot 5$ & $14 \cdot 1$ & $17 \cdot 0$ & $28 \cdot 1$ & $18 \cdot 2$ & $19 \cdot 3$ & $8 \cdot 3$ & $12 \cdot 6$ & 0.7 \\
\hline V. & $\begin{array}{l}\text { Coarse } \\
\text { Sand }\end{array}$ & $1 \mathrm{~mm}$. & 0.8 & 0.2 & $2 \cdot 5$ & $3 \cdot 2$ & $1 \cdot 3$ & $1 \cdot 2$ & $6 \cdot 3$ & $7 \cdot 5$ & $8 \cdot 9$ & $4 \cdot 0$ & $6 \cdot 0$ & $6 \cdot 2$ & $21 \cdot 0$ & $16 \cdot 0$ & 10.5 & $7 \cdot 3$ & $7 \cdot 3$ & 0.9 \\
\hline VI. & $\begin{array}{r}\text { Medium } \\
\text { Sand }\end{array}$ & $0.5 \mathrm{~mm}$ & $4 \cdot 8$ & $2 \cdot 1$ & $13 \cdot 2$ & $13 \cdot 7$ & 10.8 & $24 \cdot 0$ & $29 \cdot 2$ & $5 \cdot 5$ & $16 \cdot 3$ & $5 \cdot 9$ & $7 \cdot 3$ & $6 \cdot 9$ & $23 \cdot 4$ & $19 \cdot 7$ & $14 \cdot 9$ & $25 \cdot 7$ & $19 \cdot 9$ & $3 \cdot 6$ \\
\hline VII. & $\begin{array}{l}\text { Fine } \\
\text { Sand }\end{array}$ & $\begin{array}{c}\text { Passes through } \\
0.5 \mathrm{~mm} \text {. sieve }\end{array}$ & $90 \cdot 9$ & $95 \cdot 8$ & $82 \cdot 7$ & $68 \cdot 8$ & $85 \cdot 4$ & $72 \cdot 7$ & $56 \cdot 8$ & $16 \cdot 2$ & $12 \cdot 1$ & $17 \cdot 7$ & $8 \cdot 3$ & $10 \cdot 4$ & $5 \cdot 2$ & $9 \cdot 0$ & $5 \cdot 2$ & $18 \cdot 3$ & $6 \cdot 7$ & $69 \cdot 8$ \\
\hline VIII. & Silt & $\begin{array}{l}\text { Does not settle } \\
\text { in } 1 \text { minute }\end{array}$ & $3 \cdot 4$ & $1 \cdot 9$ & $1 \cdot 1$ & $6 \cdot 8$ & $1 \cdot 7$ & $1 \cdot 9$ & $2 \cdot 0$ & $1 \cdot 2$ & $3 \cdot 9$ & $2 \cdot 8$ & $8 \cdot 2$ & $17 \cdot 1$ & 0.6 & $3 \cdot 1$ & $1 \cdot 1$ & 0.5 & 0.3 & $24 \cdot 4$ \\
\hline
\end{tabular}


TABLE III., showing the percentages of Carbonate of Lime (or where distinguishable, of shell) in each grade of gravel or sand in the samples of bottom-deposit from the fine-textured grounds I. to VIII.

\begin{tabular}{|c|c|c|c|c|c|c|c|c|c|c|c|c|c|c|}
\hline $\begin{array}{l}\text { Number of } \\
\text { Ground. }\end{array}$ & \multicolumn{2}{|c|}{ I. } & \multicolumn{2}{|c|}{ II. } & \multicolumn{2}{|c|}{ III. } & \multicolumn{2}{|c|}{ v. } & \multicolumn{2}{|c|}{ vI. } & \multicolumn{2}{|c|}{ VII. } & \multicolumn{2}{|c|}{ viII. } \\
\hline $\begin{array}{c}\text { Number of } \\
\text { Haul. }\end{array}$ & \multicolumn{2}{|c|}{92} & \multicolumn{2}{|c|}{104} & \multicolumn{2}{|c|}{91} & \multicolumn{2}{|c|}{90} & \multicolumn{2}{|c|}{102} & \multicolumn{2}{|c|}{109} & \multicolumn{2}{|c|}{$89 \mathrm{~B}$} \\
\hline \multirow[b]{2}{*}{$\begin{array}{l}\text { Number of } \\
\text { Grade. }\end{array}$} & \multicolumn{2}{|c|}{$\mathrm{CaCO}_{3}$} & \multicolumn{2}{|c|}{$\mathrm{CaCO}_{3}$} & \multicolumn{2}{|c|}{$\mathrm{CaCO}_{3}$} & \multicolumn{2}{|c|}{$\mathrm{CaCO}_{3}$} & \multicolumn{2}{|c|}{$\mathrm{CaCO}_{3}$} & \multicolumn{2}{|c|}{$\mathrm{CaCO}_{3}$} & \multicolumn{2}{|c|}{$\mathrm{CaCO}_{3}$} \\
\hline & 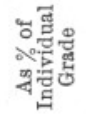 & 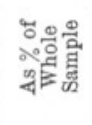 & 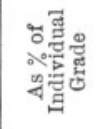 & 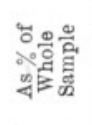 & 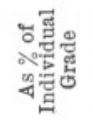 & 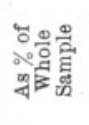 & 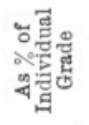 & 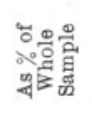 & 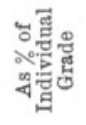 & 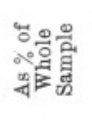 & 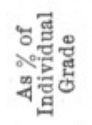 & 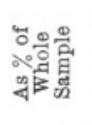 & 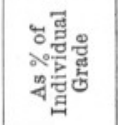 & 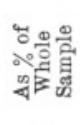 \\
\hline I. & - & - & - & - & - & - & - & - & - & - & - & - & - & - \\
\hline II. & - & - & $100 \cdot 00$ & - & - & - & $34 \cdot 62$ & 0.93 & $41 \cdot 38$ & 0.08 & - & - & $24 \cdot 44$ & 0.32 \\
\hline III. & - & - & $95 \cdot 00$ & - & - & - & $26 \cdot 50$ & 0.61 & $15 \cdot 00$ & 0.03 & $93 \cdot 00$ & 0.01 & $44 \cdot 14$ & 0.66 \\
\hline IV. & 82.43 & $0 \cdot 16$ & $93 \cdot 75$ & 0.09 & $64 \cdot 70$ & 0.32 & $57 \cdot 50$ & $1 \cdot 38$ & $39 \cdot 60$ & $0 \cdot 15$ & $72 \cdot 72$ & 0.01 & $58 \cdot 00$ & $1 \cdot 62$ \\
\hline v. & $74 \cdot 40$ & 0.59 & $57 \cdot 68$ & 0.12 & $28 \cdot 80$ & 0.72 & $39 \cdot 60$ & $1 \cdot 26$ & $24 \cdot 75$ & 0.32 & $61 \cdot 17$ & 0.73 & $60 \cdot 00$ & $3 \cdot 78$ \\
\hline VI. & $58 \cdot 00$ & $2 \cdot 78$ & $64 \cdot 37$ & $1 \cdot 35$ & $18 \cdot 70$ & $2 \cdot 47$ & $39 \cdot 60$ & $5 \cdot 42$ & $27 \cdot 00$ & $2 \cdot 91$ & $38 \cdot 75$ & $9 \cdot 30$ & $62 \cdot 73$ & $18 \cdot 32$ \\
\hline VII. & $14 \cdot 63$ & $13 \cdot 29$ & $14 \cdot 44$ & $13 \cdot 83$ & $12 \cdot 65$ & $10 \cdot 46$ & $19 \cdot 20$ & $13 \cdot 21$ & $13 \cdot 00$ & $11 \cdot 10$ & $26 \cdot 87$ & $19 \cdot 53$ & $42 \cdot 00$ & 23.86 \\
\hline Silt & $17 \cdot 41$ & 0.59 & $21 \cdot 43$ & 0.41 & $14 \cdot 85$ & $0 \cdot 16$ & $14 \cdot 67$ & $0 \cdot 10$ & $16 \cdot 25$ & $0 \cdot 27$ & $30 \cdot 00$ & 0.57 & $22 \cdot 86$ & 0.05 \\
\hline Totals & - & $17 \cdot 41$ & - & $15 \cdot 80$ & - & $14 \cdot 13$ & - & $22 \cdot 91$ & - & $14 \cdot 86$ & - & $30 \cdot 15$ & - & $48 \cdot 61$ \\
\hline
\end{tabular}


TABLE IV., showing the percentages of Carbonate of Lime (or, where distinguishable, of shell) in each grade of gravel or sand in the samples of bottom-deposit from the coarse-textured grounds IX. to XVII.

\begin{tabular}{|c|c|c|c|c|c|c|c|c|c|c|c|c|c|c|c|c|c|c|c|c|}
\hline \multirow[b]{4}{*}{$\begin{array}{l}\text { Number of } \\
\text { Grade. }\end{array}$} & \multirow{2}{*}{\multicolumn{2}{|c|}{$\frac{\text { IX. }}{94}$}} & \multirow{2}{*}{\multicolumn{2}{|c|}{$\begin{array}{l}\mathrm{X} . \\
96\end{array}$}} & \multirow{2}{*}{\multicolumn{2}{|c|}{$\begin{array}{l}\text { XI. } \\
84 \\
\end{array}$}} & \multirow{2}{*}{\multicolumn{2}{|c|}{$\begin{array}{c}\text { XII. } \\
83\end{array}$}} & \multirow{2}{*}{\multicolumn{2}{|c|}{$\begin{array}{c}\text { XIII. } \\
103\end{array}$}} & \multirow{2}{*}{\multicolumn{2}{|c|}{$\begin{array}{c}\text { XIV. } \\
85\end{array}$}} & \multirow{2}{*}{\multicolumn{2}{|c|}{$\begin{array}{c}\text { XV. } \\
97\end{array}$}} & \multirow{2}{*}{\multicolumn{2}{|c|}{$\begin{array}{c}\text { XVI. } \\
87\end{array}$}} & \multicolumn{4}{|c|}{ XVII. } \\
\hline & & & & & & & & & & & & & & & & & 10 & 05 & & 06 \\
\hline & \multicolumn{2}{|c|}{$\mathrm{CaCO}_{3}$} & \multicolumn{2}{|c|}{$\mathrm{CaCO}_{3}$} & \multicolumn{2}{|c|}{$\mathrm{CaCO}_{3}$} & \multicolumn{2}{|c|}{$\mathrm{CaCO}_{3}$} & \multicolumn{2}{|c|}{$\mathrm{CaCO}_{3}$} & \multicolumn{2}{|c|}{$\mathrm{CaCO}_{3}$} & \multicolumn{2}{|c|}{$\mathrm{CaCO}_{3}$} & \multicolumn{2}{|c|}{$\mathrm{CaCO}_{3}$} & \multicolumn{2}{|c|}{$\mathrm{CaCO}_{3}$} & \multicolumn{2}{|c|}{$\mathrm{CaCO}_{3}$} \\
\hline & 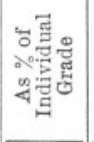 & 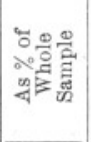 & 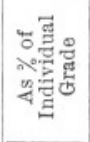 & 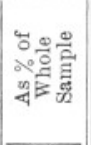 & 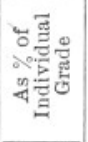 & 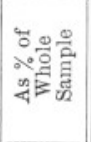 & 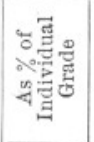 & 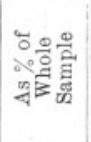 & 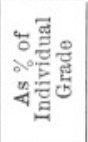 & 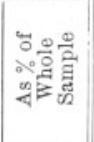 & 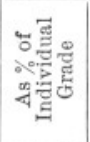 & 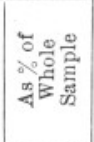 & 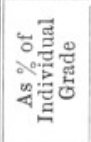 & 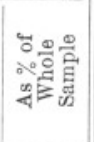 & 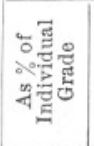 & 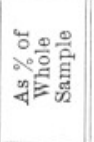 & 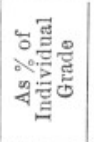 & 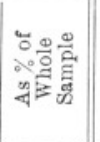 & 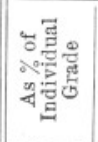 & 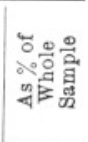 \\
\hline I. & $69 \cdot 93$ & 0.63 & - & - & - & - & - & - & - & - & - & - & - & - & - & - & $54 \cdot 43$ & $0 \cdot 76$ & 100.00 & 0.70 \\
\hline II. & $10 \cdot 21$ & $4 \cdot 53$ & $13 \cdot 48$ & $4 \cdot 76$ & $18 \cdot 73$ & $8 \cdot 88$ & $15 \cdot 52$ & $4 \cdot 33$ & $38 \cdot 47$ & $5 \cdot 15$ & $56 \cdot 00$ & $2 \cdot 30$ & $15 \cdot 28$ & $2 \cdot 05$ & $58 \cdot 80$ & $6 \cdot 29$ & $34 \cdot 21$ & $7 \cdot 90$ & $43 \cdot 75$ & $14 \cdot 78$ \\
\hline III. & $25 \cdot 50$ & $3 \cdot 57$ & $33 \cdot 00$ & $4 \cdot 72$ & $58 \cdot 00$ & $8 \cdot 41$ & $51 \cdot 00$ & $14 \cdot 43$ & $90 \cdot 50$ & $26 \cdot 24$ & $39 \cdot 50$ & $6 \cdot 91$ & $30 \cdot 50$ & $6 \cdot 25$ & $86 \cdot 50$ & $25 \cdot 26$ & $54 \cdot 00$ & $8 \cdot 21$ & $47 \cdot 50$ & $8 \cdot 93$ \\
\hline IV. & $22 \cdot 55$ & $2 \cdot 30$ & $60 \cdot 08$ & $5 \cdot 46$ & $64 \cdot 90$ & $4 \cdot 86$ & $60 \cdot 12$ & $8 \cdot 47$ & $81 \cdot 60$ & $13 \cdot 87$ & $30 \cdot 55$ & $8 \cdot 58$ & 59.95 & $10 \cdot 91$ & $79 \cdot 60$ & $19 \cdot 34$ & $64 \cdot 80$ & $5 \cdot 38$ & $78 \cdot 75$ & $9 \cdot 92$ \\
\hline v. & $13 \cdot 33$ & 1.00 & $59 \cdot 43$ & $5 \cdot 29$ & $63 \cdot 80$ & $2 \cdot 55$ & $62 \cdot 29$ & $3 \cdot 73$ & $74 \cdot 40$ & $4 \cdot 61$ & $22 \cdot 80$ & $4 \cdot 79$ & $77 \cdot 70$ & $12 \cdot 43$ & $66 \cdot 60$ & 8.92 & $75 \cdot 00$ & $5 \cdot 47$ & $73 \cdot 80$ & $5 \cdot 39$ \\
\hline VI. & $29 \cdot 14$ & $1 \cdot 60$ & $52 \cdot 00$ & $8 \cdot 47$ & $52 \cdot 52$ & $3 \cdot 10$ & $61 \cdot 21$ & $4 \cdot 46$ & $53 \cdot 71$ & $3 \cdot 70$ & $19 \cdot 20$ & $4 \cdot 49$ & $56 \cdot 40$ & $11 \cdot 11$ & $66 \cdot 00$ & $10 \cdot 16$ & $57 \cdot 00$ & $14 \cdot 65$ & $57 \cdot 70$ & $11 \cdot 48$ \\
\hline VII. & 23.83 & $3 \cdot 86$ & $32 \cdot 06$ & $3 \cdot 88$ & $35 \cdot 47$ & $6 \cdot 28$ & $47 \cdot 83$ & $3 \cdot 97$ & $40 \cdot 15$ & $4 \cdot 17$ & $13 \cdot 80$ & 0.71 & $37 \cdot 90$ & $3 \cdot 41$ & $33 \cdot 60$ & $2 \cdot 18$ & $26 \cdot 10$ & $4 \cdot 77$ & $22 \cdot 20$ & $1 \cdot 49$ \\
\hline Silt & $18 \cdot 66$ & 0.22 & $15 \cdot 50$ & 0.60 & $20 \cdot 67$ & 0.58 & $16 \cdot 50$ & $1 \cdot 35$ & $21 \cdot 16$ & $3 \cdot 44$ & $14 \cdot 67$ & 0.09 & $16 \cdot 92$ & 0.52 & $19 \cdot 80$ & $0 \cdot 10$ & $24 \cdot 00$ & $0 \cdot 12$ & $27 \cdot 00$ & 0.08 \\
\hline Totals & - & $17 \cdot 71$ & - & $33 \cdot 18$ & - & $34 \cdot 66$ & - & $40 \cdot 74$ & - & $61 \cdot 18$ & - & $27 \cdot 87$ & - & $46 \cdot 68$ & - & $72 \cdot 25$ & - & $47 \cdot 26$ & - & $52 \cdot 77$ \\
\hline
\end{tabular}


528 ON THE FAUNA AND BOTTOM-DEPOSITS NEAR THE 30-FM. LINE

\section{TABLE V.}

Showing the samples of bottom-deposit arranged according to average grade of texture, and the total percentage of carbonate of lime in each.

\begin{tabular}{|c|c|c|c|c|}
\hline No. of Sample. & & Average Grade. & & Percentage $\mathrm{CaCO}_{3}$. \\
\hline 94 & . & . $3 \cdot 66$ & $\ldots$ & $17 \cdot 71$ \\
\hline 84 & . & . $3 \cdot 704$ & $\ldots$ & $34 \cdot 66$ \\
\hline 106 & . & . $3 \cdot 803$ & $\ldots$ & $52 \cdot 77$ \\
\hline 83 & . & . 3.946 & $\ldots$ & $40 \cdot 74$ \\
\hline 96 & . & . $4 \cdot 081$ & $\ldots$ & $33 \cdot 18$ \\
\hline 87 & . & . $4 \cdot 151$ & $\ldots$ & $72 \cdot 25$ \\
\hline 97 & . & . 4.471 & $\ldots$ & $46 \cdot 68$ \\
\hline 105 & . & . $4 \cdot 498$ & .. & $47 \cdot 26$ \\
\hline 85 & . & . 4.597 & $\ldots$ & $27 \cdot 87$ \\
\hline 103 & . & . $4 \cdot 638$ & $\ldots$ & $61 \cdot 18$ \\
\hline $89 \mathrm{~B}$ & . & . $6 \cdot 386$ & $\ldots$ & $48 \cdot 61$ \\
\hline 90 & . & . $\quad 6 \cdot 561$ & $\ldots$ & $22 \cdot 91$ \\
\hline 109 & . & . $6 \cdot 749$ & $\ldots$ & $30 \cdot 15$ \\
\hline 91 & . & . $6 \cdot 814$ & $\ldots$ & $14 \cdot 13$ \\
\hline 102 & . & . $\quad 6 \cdot 849$ & $\ldots$ & $14 \cdot 86$ \\
\hline 92 & . & . $6 \cdot 971$ & $\ldots$ & $17 \cdot 41$ \\
\hline 104 & . & . 6.998 & $\ldots$ & $15 \cdot 80$ \\
\hline
\end{tabular}




\section{TABLE VI.}

Showing the distribution and abundance of each species on the grounds investigated, and its geographical distribution.

$\mathrm{M}=$ many $; \mathrm{P}=$ present in moderate numbers ; $\mathrm{F}=$ few $; \mathrm{Fo}, \mathrm{Po}, \mathrm{Mo}=\mathrm{Few}$ in some hauls, none in others, etc.

m., p., f. = many, present, few, small specimens only.

$P$ indicates that the species is present, but gives no information as to its abundance.

Geographical distribution. $\quad \mathrm{A}=$ Arctic ; $\mathrm{B}=$ Boreal ; $\mathrm{L}=$ Lusitanian.

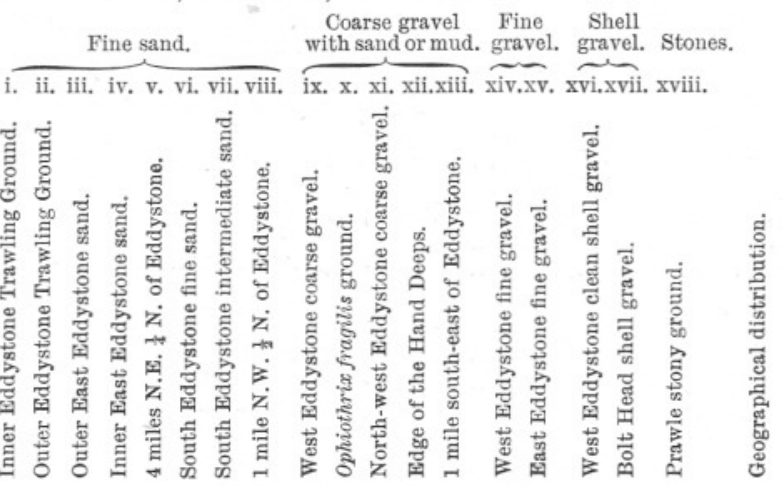

Foraminifera.

Truncatulina lobatula ( Walker and Jacob)

Porifera.

Suberites domuncula, Olivi

Cliona celata, Grant...

HydrozoA.

Tubiclava cornucopiae(Norman) - - - - F - - - - - - -

Hydractinia echinata (Fleming) $\mathrm{P}$ P Po Po P F Fo - P $---\bar{F}--$

Eudendrium rameum (Pallas)... $-\frac{-}{\mathrm{F}}-\frac{-}{\mathrm{P}}-\frac{\mathrm{P}}{\mathrm{F}}-\frac{\mathrm{P}}{\mathrm{P}}-\mathrm{C}-\mathrm{F}-$

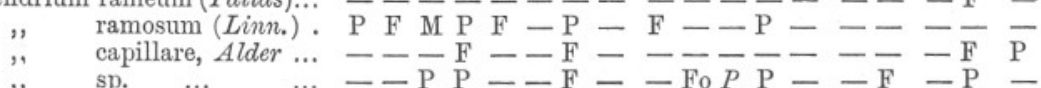

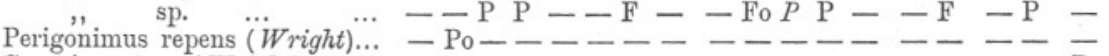

Garveia nutans (Wright) $\quad$... $--------\overline{-}-\overline{-}-\overline{\mathrm{P}}$

Heterocordyle Conybearei (All.) $\mathrm{P}------------\ldots$

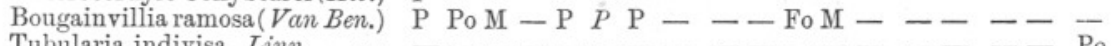

Tubularia indivisa, Linn. $\quad \ldots \quad-\frac{-}{\mathrm{M}}-\overline{\mathrm{M}}-\overline{\mathrm{M}}--\overline{\mathrm{M}}-\overline{\mathrm{P}}-\overline{\mathrm{P}}$

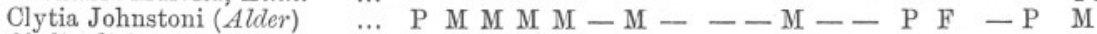

Obelia dichotoma (Linn.) $\quad \cdots \quad$ P $-\mathrm{F}-\mathrm{F}-\mathrm{Fo}-\overline{\mathrm{P}}-\mathrm{C}-\mathrm{-}-\mathrm{P}-\mathrm{F}$

Campanularia Hincksii, Alder. $\mathrm{P}-\mathrm{P} \mathrm{P}-\mathrm{P} P \mathrm{P} F-\overline{\mathrm{F}}-\mathrm{P}--\mathrm{P} \mathrm{P}$ ," verticillata(Linn.) $\mathrm{F}-\mathrm{Fo}-\mathrm{P}---\mathrm{P}-\mathrm{P}-\mathrm{P}-\mathrm{P}$ Fo flexuosa (Hincles)

Lovenella clausa (Lovén)

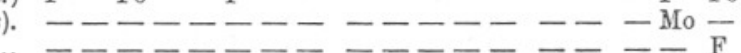

Opercularella lacerta (Johnston) - - - - - - - - - - - - - - - - F

Lafoëa dumosa (Fleming) $\quad$...

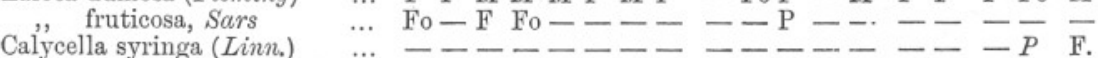

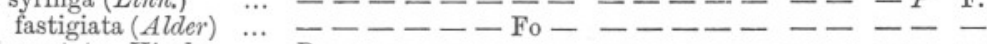

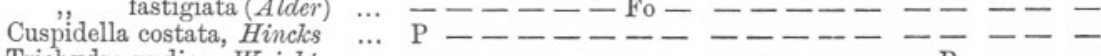

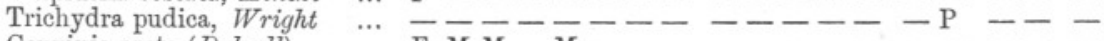

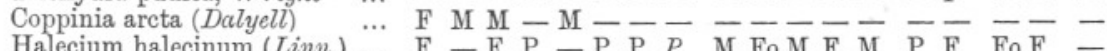

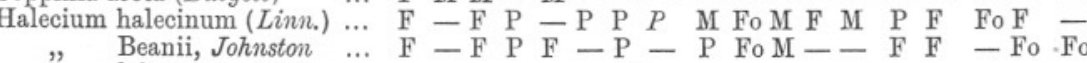

" labrosum, Alder $\cdots$ -
B.

A. B.

A.L.

A.L.

B.

L. B.

B.

B.

B.

A.L.

L. B.

A.L.

L. B.

B.

B.

A.L.

A. B.

A. L.

B.

B.

A. B.

A.L.

L. 
Sertularella Gayi, Lamouroux. $P$ P M M P M P F Fo P I F F F Fo - -

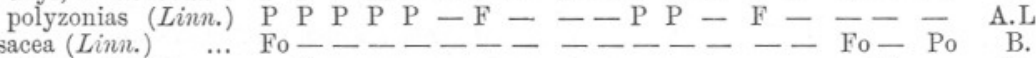

Diphasia rosacea (Linn.)

", attenuata, Hincks $\quad$...

Sertularia abietina, Linn.

', argentea, Ellis and Solander

Hydrallmania falcata (Linn.)...

Thuiaria articulata (Pallas) ...

Antennularia antennina (Linn.)

Aglaophenia $\begin{gathered}\text { ramosa, Lamarck } \\ \text { myriophyllum }\end{gathered}$

(Linn.)

Plumularia pinnata (Linn.) ...

, $\quad$ setacea (Ellis) $\quad \ldots$

", frutescens (Ellis and

Solander)

ACTINOzOA.

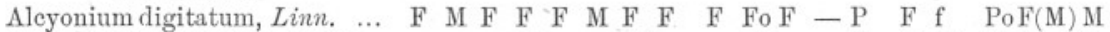
Sarcodictyon catenata, Forbes... - - Fo - - Mo-- - Fo- - F P F M M M Gorgonia verrucosa, Pallas $\quad . .--------------\mathrm{Fo}_{-}$

Caryophyllia Smithii (Stokes)... - - - - P - M P P P M F MoF M

Epizoanthus incrustatus (Düb.

and Kor.)

Sagartia parasitica $($ Couch $) \quad \cdots$

Adamsia palliata (Bohadsch) $\cdots$

Paraphellia expansa Haddon ....

Corynactis viridis, Allman

Echinodermata.

Cucumaria pentactes $(\operatorname{Linn}$.$) ... -----\mathrm{F}_{0}-------$ , lactea (Forbes and Goodsir)

Thyone fusus (O.F.M.)

Holothuria nigra (Gray)

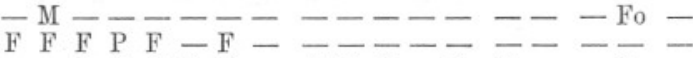
- $\mathrm{F}$ P P $\overline{\mathrm{P}} \mathrm{F}-\overline{\mathrm{P}} \overline{\mathrm{F}} \overline{\mathrm{Fo}}-\overline{\mathrm{F}} \overline{\mathrm{F}}-\overline{\mathrm{F}}-$ $-\overline{\mathrm{F}}-\mathrm{-}-\mathrm{F}-\mathrm{Fo}-\mathrm{F}-\mathrm{F}---\mathrm{-}--$ $---\overline{-1}-\overline{-}----\overline{-}-\overline{-}-\overline{\mathrm{Po}}$ .. - - F $--\mathrm{Fo}_{0}-----$ Fo Fo Fo ... $--------1-1--$

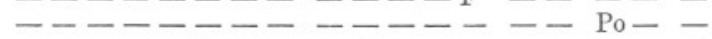

Astropecten irregularis (Penn.) M M M F Fo Fo $-\mathrm{f}-\mathrm{Fo}-\mathrm{f}$ Fo Fo- Luidia Sarsi, Düb. and Kor. ... - Fo- - - - - - - F -

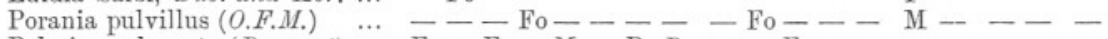
Palmipes placenta (Pennant) ... Fo $-\mathrm{F}-\mathrm{M}-\mathrm{P} P-\frac{\mathrm{F}}{\mathrm{P}}-\overline{\mathrm{F}}--\overline{\mathrm{F}}$ Solaster papposus (Linn.) $\quad \ldots$ Fo - Fo Po M - F - F fo f $-\mathrm{F}$ f - fo $\mathrm{F}$ F Henricia sanguinolenta (O.F.M.) - - Fo P $-\mathrm{F} F--\frac{\mathrm{F}}{\mathrm{P}}-\mathrm{Fo}---$ Asterias glacialis, Linn. .... Tubens, Linn.

Ophiura ciliaris (Linn.) , albida, Forbes

Amp̈hiura elegans (Leach)

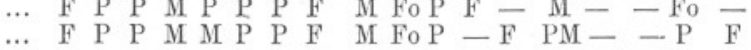

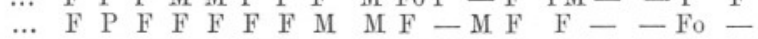
$\cdots-2-$ fo $-\mathrm{F} \quad \mathrm{F} \quad \mathrm{F} \quad \mathrm{M}-\mathrm{M}-\mathrm{P} \quad \mathrm{F}--\mathrm{F} \quad \mathrm{Fo}_{0}$ … - - - - - - - $-1-\mathrm{F}-\mathrm{F}$ Amphiura elegans $($ Leach $) \quad \ldots \quad-\ldots-1-\mathrm{P}_{-}-\ldots-$ M $\mathrm{F}-$

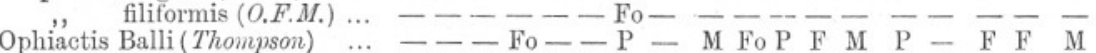
Ophiocoma nigra (O.F.M.) $\quad \cdots-----\frac{\mathrm{P}}{\mathrm{F}} \mathrm{F}$ Pof - Fo - fo $\mathrm{F}$ Mo Ophiothrix fragilis (O.F.M.) $\quad \ldots$ f $\mathrm{f}$ f $\mathrm{f}$ f $-\mathrm{f}$ P $\mathrm{P}$ M M M M M $\mathrm{M}-$ fo $\mathrm{F}$ F

Echinus acutus, Lamk.

$$
\text { , miliaris, Leske }
$$

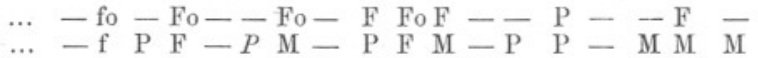
" esculentus, $\operatorname{Linn}$ ...

Echinocyamus pusillus (O.F.M.) Spatangus purpureus (O.F.M.)

Echinocardium cordatum (Pen.) $--\mathrm{F}-\mathrm{P}$ P F FoP F F P PoF $\mathrm{f}$ $-\mathrm{F}---\mathrm{Po}----P$ Fo- $\mathrm{P}$ F $\mathrm{F}$ $---1-$ Fo P - Fo- - F $-\mathrm{P}$ M Po ,, pennatifidum, Nor.
B.

L.B.

A.L.

A.L.

A.B.

L.

B.

L.B.

B.

L.B.

L.

L.

B.

L.

L.

L.

B.

L.

L. (?)

B.

L.

A.L.

$B$.

L.B.

B.

L. B.

B.

L.

A.B.

A.B.

L.

B.

L. B.

A.L.

L. B.

A.L.

L. B.

B.

A.B.

L. B.

L B.

L.B.

L. B.

L. B.

L. B.

L. B. 


\section{Fine sand.}

Coarse gravel Fine Shell with sand or mud. gravel. gravel. Stones.

\section{Nemertina.}

Carinella superba $(K \ddot{o} l l$.

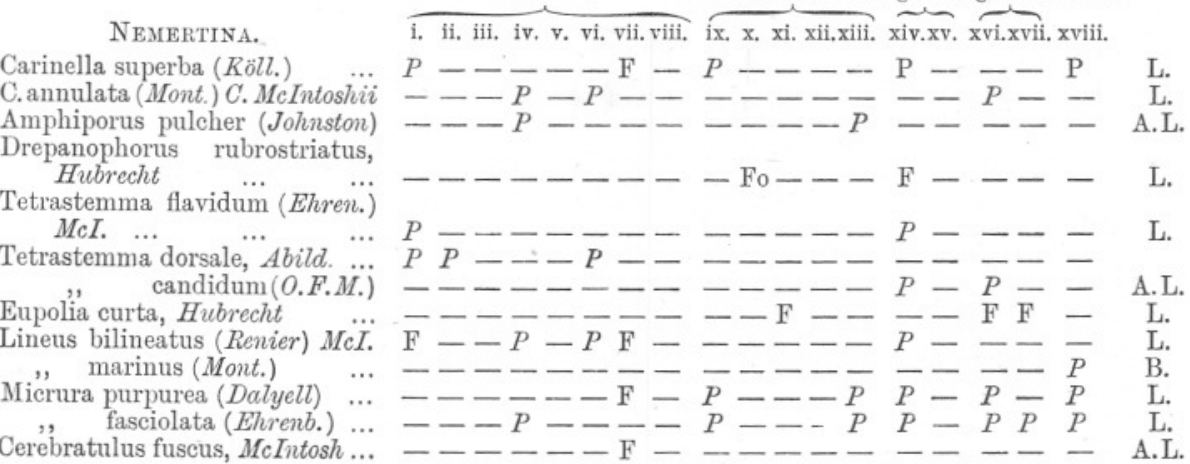

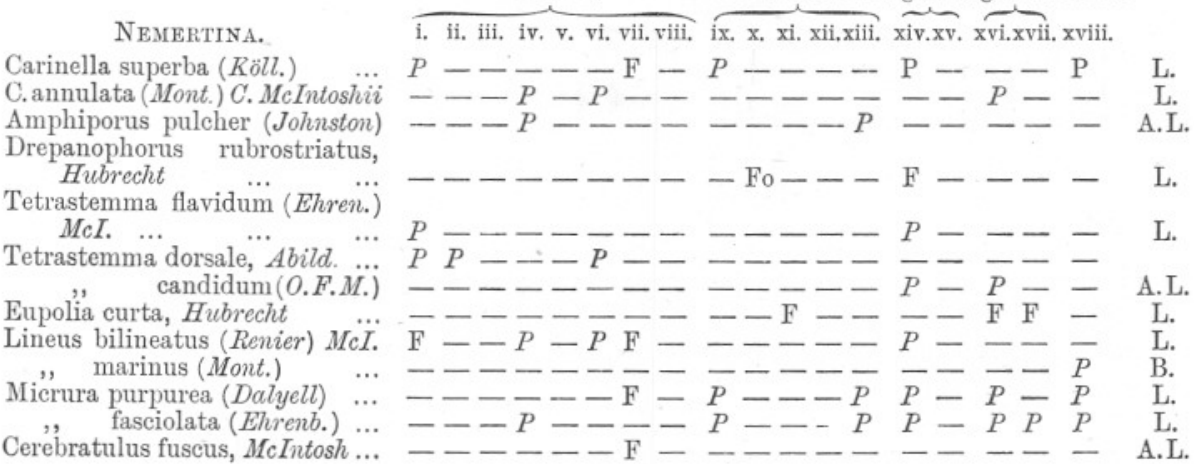

Drepanophorus rubrostriatus,

Hubrecht
Tetrastemma flavidum (Ehren.) McI.

Tetrastemma dorsale, Abild. $\cdots$ candidum (O.F.M.)

Eupolia curta, Hubrecht

Lineus bilineatus (Renier) $M \ddot{c} \ddot{I}$.

," marinus (Mont.)

Micrura purpurea (Dalyell) $\cdots$ fasciolata (Ehrenb.) ...

Cerebratulus fuscus, McIntosh .... Turbellaria.

Eurylepta cornuta (O.F.M.) Gephyrea.

Phascolion strombi (Mont.) Polychaeta.

Polygordius sp.

Euphrosyne foliosa, Aud.\& Ed $\ddot{d w}$. Aphrodite aculeata, Linn.

Hermione hystrix, Sav.

Lepidonotus squamatus (Linn.)

Eunoe nodosa (Sars.

Lagisca propinqua (Mlmgn.) $\ldots$ rarispina (Mlmgn.) …

Harmothoë imbricata (Linn.) ...

Evarne impar (Johnston)

Polynoe scolopendrina, Sav. ...

Halosydna gelatinosa (Mlmgn.)

Hermadion assimile (McInt.) ...

Acholoe astericola, Clpd.

Hyalinoecia tubicola (O.F.M.)

Lumbriconereis (large) (small)

Nereis fucata (Sav.)...

Typosyllis alternosetosa (S. Jos.

Ehlersia cornuta (Rthke.)

Eulalia viridis, Sav....

Amblyosyllis spectabilis (John.

Polydora caeca (Oerstd.)

Nephthys Hombergii (A. \& $\ddot{E}_{\text {. }}$ )

Glycera convoluta (Kef.) ...

Chaetopterus variopedatus, $C l \dddot{p} \dot{d}$.

Pectinaria auricoma

Polymnia nebulosa (Mont.)

Nicolea venustula ( $v$, Mrzlli.)

Thelepus sp.

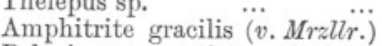

Polycirrus aurantiacus $(G r$. ) ..

Terebellid tubes $\quad . . . \quad \ldots$

Sabella (pavonina ?) ...

Sabellaria spinulosa (Lenck)

Filograna implexa, Berkley

Dasychone bombyx (Dal.)

Protula tubularia (Mont.)

Hydroides norvegica (Gunn) ...

Potamoceros triqueter (Linn.)...

Spirorbis sp.
L.

A.L.

L.

A. L.

L.

B.

L.

A.L.
L.

L. B.

L.

B.

A.B.

L.B.

A.B.

A.B.

A. B.

L.

L.

B.

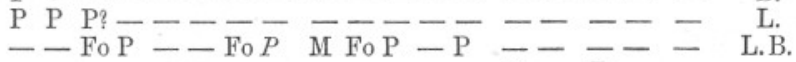

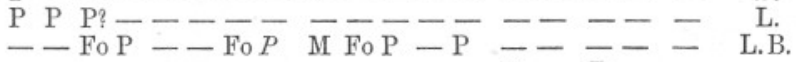

$------\bar{P}-\overline{F_{0}}-$

With Eupagurus Bernhardus in Buccinum shells. - B. Fo $\mathrm{P}$ M Fo $-\mathrm{P} \mathrm{M}---\mathrm{F}----\mathrm{Fo}_{-} \mathrm{L}$. - - - P - - - - - - - - B.

----------- Fo $_{-}-$A.L. $-----\mathrm{F}_{0}---------1$ A.L.

- - - - - P - - - - - - - Fo - - A.L.

- Fo- - - - - - - - - - - A.L.

$--\frac{-}{\mathrm{P}}-\overline{\mathrm{P}}-\overline{\mathrm{P}}-\overline{\mathrm{M}}-\mathrm{F} \mathrm{sp}$ ? $-\mathrm{L}$.

Fo- F Fo-P P F M Po M F M M fo - Fo Fo L.B.

$-----\mathrm{F}_{\mathrm{F}}-\mathrm{F}_{0}-\mathrm{F}--1-\mathrm{P}$ F $\quad$ L.B.

----7 Fo- $\mathrm{F}--\mathrm{F}$ Fo- - - L.B.

f $-P--\mathrm{F}$ Fo - Fo- ----- A.L.

P P M M - M M P M FoM $P-$ Fo --- A.L.

$-----\mathrm{F}_{0}----\frac{\mathrm{F}}{\mathrm{P}}--\mathrm{Fo}-\mathrm{A}$.B.

$-----\frac{-}{P}-\frac{-}{P}-\overline{\mathrm{F}}-\overline{\mathrm{M}}-\mathrm{L}$.

P F P P P P $-\mathrm{P}$ FoP - P -- A.B.

$----\mathrm{P} P---\mathrm{P}-----P \quad P \quad \mathrm{~B}$.

$-----\mathrm{P}-P---\mathrm{M} \quad \mathrm{P}----\mathrm{L} . \mathrm{B}$.

P P M P $-\mathrm{P}$ M - M Fo-P P - Fo- - L.B.

$-----\mathrm{F} P-\mathrm{Fo}_{-} \mathrm{P}-\mathrm{Fo}-\mathrm{F} \mathrm{F}-\mathrm{L}$.

$-\overline{\mathrm{P}} \mathrm{F}_{0}-\overline{\mathrm{F}} \mathrm{P}-\mathrm{P} \mathrm{F}_{0}-\overline{\mathrm{P}} \mathrm{P}--\mathrm{F} \overline{\mathrm{F}}_{\mathrm{L}}^{\mathrm{L}} \mathrm{B}$.

F P P - F P P - P Fo P - P. P F F P P L.B.

$-\mathrm{F}_{0}-\mathrm{P}$ F $-\mathrm{P}-\mathrm{P}-----\frac{\mathrm{P}}{\mathrm{P}} \mathrm{L} . \mathrm{B}$. 


\section{Fine sand. $\quad \begin{gathered}\text { Coarse gravel Fine } \\ \text { with sand or mud. gravel. gravel, Stones. }\end{gathered}$

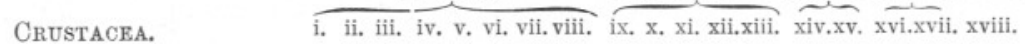

Homarus vulgaris, M. Edw. ... Fo $\quad$ Fo --------------- B.

Pandalus brevirostris, Rthke.... - - M M $\mathrm{M}-\mathrm{F}-\mathrm{F}--------$ B.A.

Eupagurus Bernhardus, Linn... P M M P P P F - P FoF F - F - F F B.A.

Prideauxii (Leach).. $-1-\mathrm{P}$ P P P F $P$ P $P$ Fo- $-\overline{\mathrm{F}}$ Fo- - Fo - L.B.

" cuanensis (Thompson) $-----\mathrm{F}---\mathrm{P}-\mathrm{P}$ Fo - Fo Fo - L.

Anapagurus laevis (Thompson) - M Fo Fo M P F P $\mathrm{M}-\mathrm{Po}----$ - Fo F $\mathrm{L}$.

$\begin{array}{llllllllllllllll}\text { Porcellana longicornis (Linn.)... } & \text { P } & \text { P } & \text { M M M } & \text { M F } & P & \text { M F } & \text { M }-P & \text { P } & - & \text { P } & \text { M } & \text { M } & \text { L. }\end{array}$

$\begin{array}{llllllllll}\text { Galathea dispersa, Bate } & . . & \text { P } & \text { M M M M M M } P \text { M Fo M }- \text { M P F Fo F } & \text { M } & \text { L. }\end{array}$

Stenorhynchuslongirostris, $F a b$. $\quad$ F $\quad$ F $\quad$ M M M P P $P$ P Fo P $-P$ P F - Fo Fo L L

Inachus dorsettensis (Pennant) Fo F M M M P P P M $-\mathrm{P}-\mathrm{P}$ P F - Fo Fo $\mathrm{L}$.

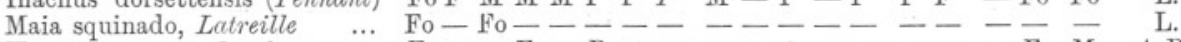

Hyas coarctatus, Leach $\quad$... $\quad$ Fo - Fo $-\mathrm{P}----------\mathrm{F} \quad \mathrm{M} \quad$ A.B.

Eurynome aspera (Pennant) $\quad \ldots$ F Fo F Fo - F F F M - F F F Fo - F - Fo P $L$.

Cancer pagurus, Linn. $\quad \ldots .-$ Fo- - Fo - - - - - - - B.L.

Pilumnus hirtellus, Leach $\quad \ldots \quad--------------$ Fo $\quad$ L.

Portunus depurator $(\operatorname{Linn}) \quad \ldots--\mathrm{Mo} \mathrm{M}-\mathrm{P}-\mathrm{F}----\mathrm{P}$ Po $--\overline{-}-\mathrm{L}$. B. pusillus, Leach $\quad \ldots .--P_{0}-\mathrm{F}$ Fo F P FoM $-\cdots-$ FoF Fo L.

Corystes cassivelaunus (Penn.) MoFoMo-F - $-1------$ Fo - L.

Atelecyclus heterodon, Leach... Fo $_{-}-\mathrm{F}_{0}-\mathrm{P}$ Fo $-\mathrm{m}-\overline{\mathrm{F}}-\overline{\mathrm{M}}-\mathrm{F}_{0}-\mathrm{Fo}$ Fo L.B.

Ebalia tumefacta (Montagu) ... - Fo $----F$ M Fo P - Fo - F F F L.B.

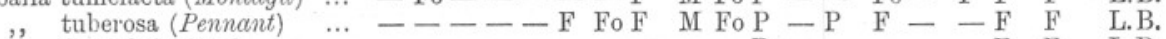

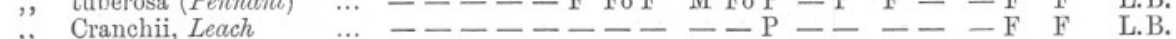

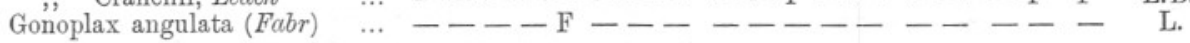

Balanus crenatus, Bruguière ‥ $-----\mathrm{P}--\mathrm{F} P-\mathrm{P}-P P-$ A.L.

Scalpellum vulgare, Leach $\quad \ldots$. P $\mathrm{P}$ M M - P P - M Fo P P - P F $-\mathrm{F}-$ L.B.

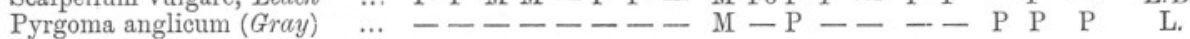

Phthisica marina, Slabber $\quad \ldots---------P---P---$ L.B.

Ampelisca spinipes, Boeck $\quad \ldots \quad--------------P \quad P \quad B$.

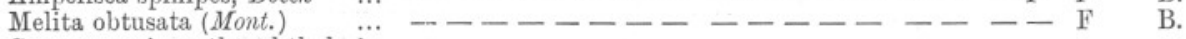

Gammaropsis erythrophthalmium

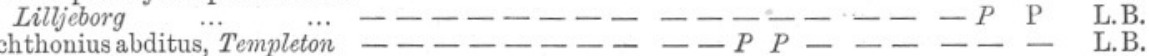

Mollusca. Living.

Pholas parva, Pennant $\quad$... --------------7 Fo $\mathrm{L}$.

Pholadidea papyracea (Turton) - - - - - - - - - - - M L.

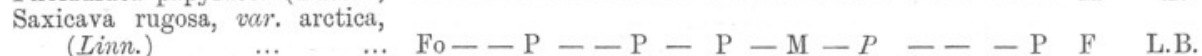

Pandora obtusa, Leach $\quad \ldots \quad-----\mathrm{F}_{0}--------$ A.L.

Lyonsia norvegica (Chemnitz)... - - - - - - - Fo - A.L.

Psammobia costulata, Turton... - - - - - - - - - - F - - L.

Tellina crassa, Pennant $\quad$.. ------------ F -- L.

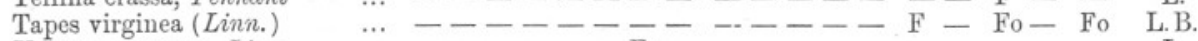

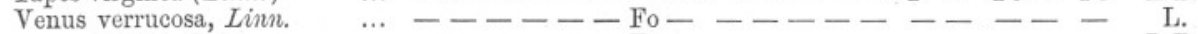

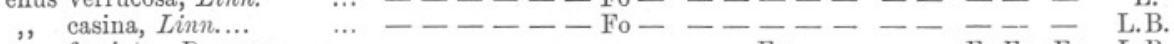

", fasciata, Donovan $\quad \ldots$-..

", ovata, Pennant $\quad$... - - - - Fo - - - - - - - - L.B.

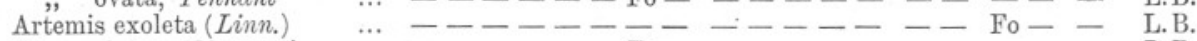

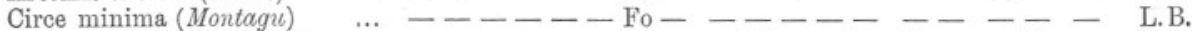

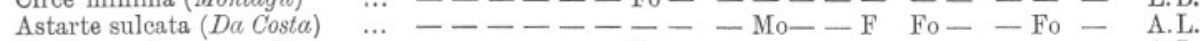

Cardium echinatum, Linn $\quad \ldots \quad-----$ Fo $_{-}---------$A.L.

,, norvegicum, Spengler $---\mathrm{F}-\mathrm{F}-\mathrm{F}$ Fo $--\mathrm{P}-\mathrm{Fo}--$ L.B.

Montacuta substriata (Montagu) - - - - - - - - P - P P - L B.

Kellia suborbicularis (Montagu) - - - - Fo - Fo P - Fo - - Fo L.B.

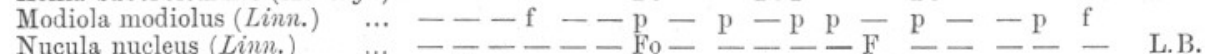

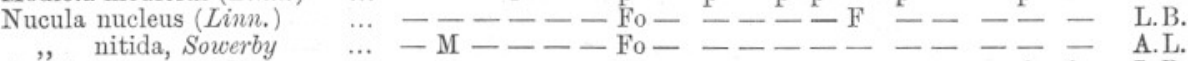

Area tetragona, Poli. $\quad \cdots .-----\bar{f}$ f $\quad$ L.B.

Pectunculus glycimeris (Linn.) - - - - - - - - - $--\mathrm{f}-\mathrm{M}$ fo L.B.

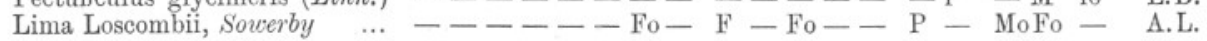


Fine sand. Coarse gravel Fine Shell
with sand or mud. gravel. gravel. Stones.

Pecten tigrinus, Müller , maximus (Linn.) opercularis (Linn.) Anomia ephippium, Linn. $\quad \ldots--\mathrm{P}---\mathrm{P}-\mathrm{M}$ Fo P m $\mathrm{P} \stackrel{\mathrm{P}}{\mathrm{P}}-\mathrm{P}-$

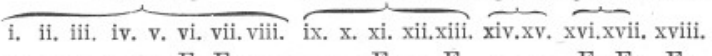

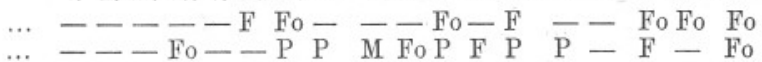
... Fm Fm MFm Mm F P Fm M Fo Fmf F MF $p$ f Fo Fo 2. $\mathrm{P}-\mathrm{P}-\mathrm{P} \mathrm{F}-\mathrm{P} \mathrm{P}-\mathrm{P}-\mathrm{P}$.

Dentalium entalis, Linn. $\quad \ldots \quad \mathrm{M}-\mathrm{M}--\mathrm{P} \mathrm{P}--\mathrm{Fo}--\mathrm{F}-\mathrm{F}$

Pileopsis hungaricus $(\operatorname{Linn}.) \quad \ldots--\overline{\mathrm{N}}-\mathrm{F} \mathrm{P}--\mathrm{P}--\mathrm{P}-\mathrm{Fo}-$

Emarginula reticulata, Sowerby - - - - P - Fo M - P F P M

," rosea, Bell

Trochü zizyphinus, Linn.

Turritella communis, Risso $\quad$...

Turritella communis, Risso ....

Eulima polita (Linn.)

Natica nitida (Donovan)

Lamellaria perspicua (Linn.) ...

Nassa incrassata (Müller) $\quad .$.

Buccinum undatum, Linn.

Fusus islandicus, Chemnitz

Cypraea europaea, Montagu

Ovula patula (Pennant)

Chiton asellus, Chemnitz

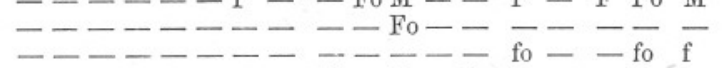
$-------\overline{-}-\overline{\mathrm{F}}-\mathrm{Fo}-\mathrm{F}-\mathrm{fo}-\mathrm{fo} \mathrm{f}$

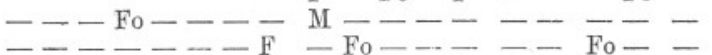
$-----\mathrm{F}_{0}-\mathrm{F}---$ $-----\frac{-}{\mathrm{F}}-\mathrm{-}-\mathrm{Fo}-\mathrm{F}-\mathrm{F}-\overline{-}-$ $------\mathrm{F}--\mathrm{F}----\mathrm{Fo}_{\mathrm{F}}$

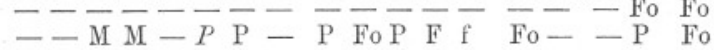
$-\frac{-}{\mathrm{F}} \mathrm{F}--\mathrm{F}-\overline{\mathrm{F}}--\mathrm{-}-\mathrm{-}-\mathrm{F}-\mathrm{Mo}-$ . $\mathrm{F}----\mathrm{F}---\ldots-\mathrm{Fo}_{0}$

L. B.

L. B.

L. B.

L. B.

B.

A. B.

,, discrepans, Brown $\ldots$... $-\ldots-\ldots----------\mathrm{Fo}_{-}$ Proneomenia aglaopheniae, Mar.

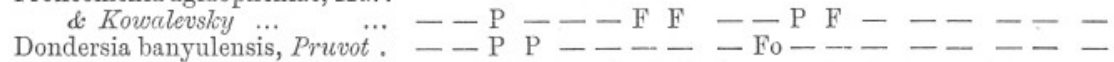

Scaphander lignarius, Linn. ... - - - - - - - - F - - - - -

Oscanius membranaceus (Mont.) ---------------

Tritonia Hombergii, Cuvier ... - fo $--------------P-$

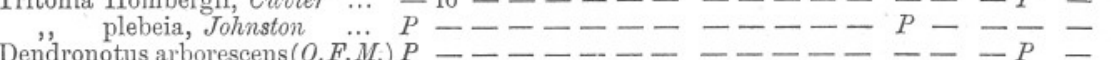

Doto frotus arborescens $(0.1$

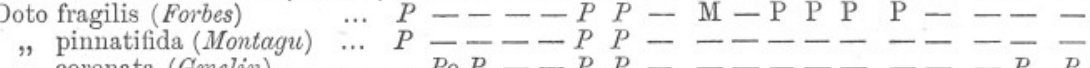

, coronata (Gmelin)

Hero formosa, Lovén

Cratena viridis (Forbes)

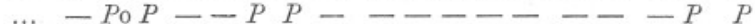

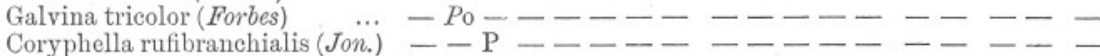

... $-\mathrm{Fo}----------$

... $P---------1$

, Landsburgii (Alder

\& Hancock) $\quad \ldots$ (Cuvier)
Archidoris tuberculata (C- $-P--\bar{P}-\mathrm{P}------P$ Lamellidoris oblonga, Alder \&.

Hancock
Triopa claviger $(O . F . M$.

Aegirus punctilucens, D'Orbigny $--\ldots----\ldots-\ldots-$ Fo --

Polycera quadrilineata (O.F.M.)

Mollusca. Shells.

Lyonsia norvegica (Chemnitz) ... - - - - F - - F $-\mathrm{F}---\frac{\mathrm{F}}{\mathrm{F}}-\mathrm{F}-\mathrm{F}$

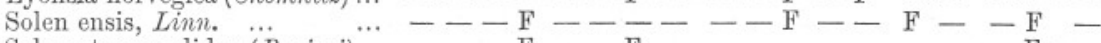

Solecurtus candidus (Renieri)... - - F - F $-\mathrm{F}------$

Psammobiaferroensis(Chemnitz) - - - F F - - - - Fo - - -

Tellina crassa, Pennant donacina, Linn.

Lutraria elliptica, Lamarck

Tapes virginea (Linn.)

Venus verrucosa, Linn.

, striatula, Donovan

, fasciata, Donovan

‥ - - - - - - - - - - $P$ Fo $\therefore---\frac{-}{\mathrm{N}} \overline{\mathrm{P}}-\overline{\mathrm{P}} \overline{\mathrm{F}}-\mathrm{\textrm {F }}-\overline{\mathrm{P}}-\overline{\mathrm{M}}-\overline{\mathrm{P}} \overline{\mathrm{M}} \overline{\mathrm{Fo}}$ $\ldots---\mathrm{M}-\mathrm{M} \mathrm{M}-\mathrm{M} \mathrm{F} \mathrm{M}-P$ M $\mathrm{P}$ M $\mathrm{P}$ Fo .. - - - - - - - F- - - - - - - - - - - -

A.L. 
Venus ovata, Pennant Artemis exoleta (Linn.) Cyprina islandica (Linn.)

Astarte sulcata $(D a$ Costa)

Cardium echinatum, Linn.

Fine sand,

Coarse gravel Fine Shell

with sand or mud, gravel. gravel. Stones.

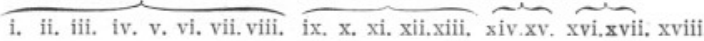
… $---\overline{\mathrm{P}}-\overline{\mathrm{F}}-\mathrm{M} \mathrm{F}-\overline{\mathrm{M}}-\mathrm{P}-\overline{\mathrm{P}}-\overline{\mathrm{M}} \mathrm{\textrm {F }}-$ $\cdots-\mathrm{P}-\mathrm{P}-\mathrm{P} F-\mathrm{F}-\mathrm{F}-\mathrm{P}--\mathrm{M}-$ $\cdots \quad-\frac{\mathrm{M}}{\mathrm{M}}---\overline{\mathrm{M}} \overline{\mathrm{M}}-\mathrm{P}-\mathrm{\textrm {F }}-\frac{\mathrm{F}}{\mathrm{P}} \overline{\mathrm{P}} \mathrm{F}-\mathrm{F}$ Fo norvegicum, Spengler. $---\mathrm{P}--\mathrm{M}$ P $\mathrm{M}$ F $P$ p $P$ M - M P Fo

Nucula nucleus (Linn.) $\quad$... $-----\mathrm{P}-----\frac{\mathrm{P}}{\mathrm{P}}--\mathrm{M}$

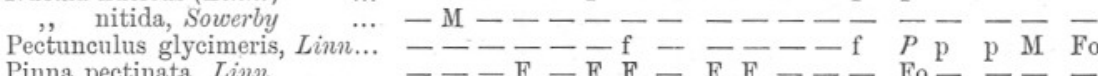

Pinna pectinata, Linn. $\quad \ldots--$ - F - F F - F F - - Fo $\frac{\text { F }}{P}-\frac{1}{\mathrm{P}}$

Lima Loscombii, Sowerby $\quad \ldots \quad-\ldots------$ F Mo- - M P P - Fo

Pecten tigrinus, Müller $\quad \ldots---\frac{-P}{\mathrm{~F}} \mathrm{~F}-\overline{\mathrm{F}}-\mathrm{F}-\frac{\mathrm{P}}{\mathrm{P}}-\mathrm{Fo}$

", maximus (Linn.) ... - - $-\mathrm{M}-\mathrm{P} \mathrm{M}-\mathrm{M} \mathrm{P}$ M F $\mathrm{M}$ M P $\mathrm{P}$ F

$", \quad$ opercularis (Linn.) $\quad \ldots-$ - F - M F M M P M M M M M M P P M P

Ostrea edulis, Linn....

Dentalium entalis, Linn. $\quad \ldots .-\bar{P}$ P F $-\bar{P} P$ P - P $P--\bar{F}-\bar{P}-$

Trochus granulatus, Born $\quad \ldots------P-\mathrm{F}-----\mathrm{F}-$

Turritella communis, Risso $\quad \ldots \quad----\mathrm{F}-\mathrm{M}-\mathrm{F}--\mathrm{F}---$

Aporrhais pes-pelecani (Linn.) - Fo- - - F $-\mathrm{F} F-\mathrm{F}-\mathrm{F}$ Fo -

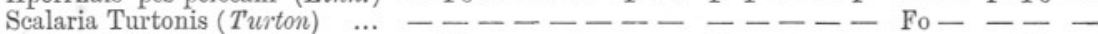

Natica nitida (Donovan) $\quad \ldots-\mathrm{P}-----\mathrm{P}-----7-\mathrm{Fo}_{-}$

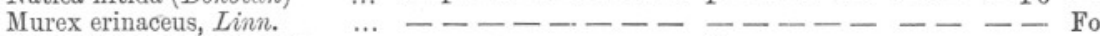

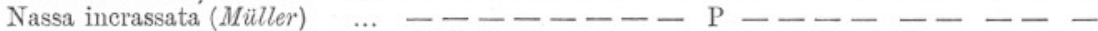

Buccinum undatum, Linn. $\quad \cdots \quad$ P P P P - - - - - F - Fo $--\frac{-}{\mathrm{F}}$

\section{PolyzoA.}

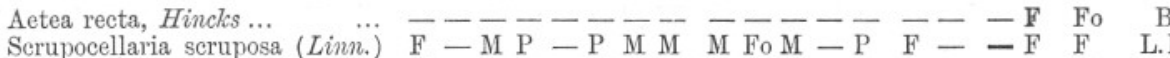

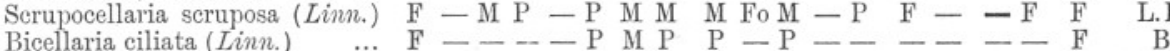

Bugula turbinata, Alder $\quad \ldots \quad--------------$ F

,$\quad$ avicularia (Linn.) $\quad \ldots-$ - Fo - P F P - Fo $--F-F-$

,. flabellata (Thompson)... - - F Fo $--\mathrm{P}-\mathrm{F}_{0}------$

Cellaria sinuosa (Hassall) $\quad$.... M F M M F M M M - Fo F - F - - - - Fo

,2 fistulosa(Linn.) $\quad \ldots$ M F M M F M M M F Fo F f F F -

", Johnstoni, Busk $\quad$,... $---\mathrm{F}-----------$

Membranipora Dumerilii(Aud.) $\mathrm{P}-\mathrm{Fo}-\overline{\mathrm{F}}-\overline{\mathrm{F}}-\mathrm{F}---\overline{\mathrm{F}} \mathrm{F}$ P , catenularia(Jam.) $--\mathrm{F}--\mathrm{F}-----\mathrm{P}--\mathrm{F} 0 \mathrm{P}$ , $\quad$ Flemingii (Busk)

Micropora coriacea (Esper) ...

Cribrilina radiata (Moll.) $\ldots$ figularis (Johnston) ....

Microporella ciliata (Pallas) $\ldots$
Malusii (Audouin)

$$
\text { ", violacea (Johnston) }
$$

Chorizopora Brongniartii (Aud.)

Schizoporella linearis (Hassall) auriculata (Hasl.)

Schizotheca fissa (Busk)

Hippothoa divaricata, Lamrx.

Lepralia foliacea (Ellis \& Sol.) pertusa (Esper)

Porella concinna (Busk)

$-\bar{P}-\mathrm{F}--\mathrm{F}--\overline{-}--\mathrm{P}--\mathrm{F} 0 \mathrm{P}$ $---\frac{\mathrm{P}}{\mathrm{P}}--------\overline{\mathrm{P}}-\mathrm{F} \stackrel{\mathrm{P}}{\mathrm{P}} \mathrm{P}$

$---\mathrm{P}--\overline{\mathrm{P}}------\mathrm{P}-\mathrm{P}-\mathrm{F} \stackrel{\mathrm{P}}{\mathrm{P}}$ - FoP $-\mathrm{P}-\mathrm{P} F \overline{\mathrm{F}}-\mathrm{P}-\mathrm{P} \mathrm{P} P$ $---\mathrm{P}--\mathrm{F}------\mathrm{P}-\mathrm{P} P \mathrm{P}$ $--\mathrm{P}-\mathrm{P}-\mathrm{P} F \mathrm{~F}-\mathrm{P}--\mathrm{P} P$ Fo $-\mathrm{P}-\mathrm{P}-\mathrm{P}-\mathrm{F} P-\mathrm{P}-\mathrm{F} \mathrm{P} P$ $-\mathrm{F}_{0} \mathrm{P} F-\mathrm{P}-\mathrm{P}$ F F $P-\mathrm{P}-\mathrm{F} \mathrm{P} \mathrm{P}$ $-------1---$ Fo- F F - L. $\mathrm{F}--\mathrm{P}--\mathrm{P}-\overline{\mathrm{P}}-\mathrm{P}-\mathrm{P} P \mathrm{P}$ A.L. Fo- $-\mathrm{F}_{0}-----\mathrm{F}_{0}-\mathrm{Fo}---\mathrm{L}$. - $-\mathrm{P}-\mathrm{F}-\mathrm{F}-\mathrm{F}--\mathrm{Fo}-\mathrm{Fo}$ A.L. Fo- $-\mathrm{P}-\mathrm{F}-\mathrm{M}$ F $\mathrm{P}-\mathrm{P}-\mathrm{Fo} \mathrm{P} \mathrm{P}$ A.L. Smittia trispinosa (Johnston) $\ldots-\ldots-1 \mathrm{P}--\mathrm{F}--\mathrm{F}--\mathrm{P}-\mathrm{Fo} \mathrm{P} \quad \mathrm{P} \quad$ A.L. cheilostomata (Manzoni) $--\mathrm{P}---\mathrm{F}--\mathrm{F}-$ Fo P $\mathrm{F}$

Phylactella collaris (Norman). $-\overline{F_{0}}-\overline{\mathrm{F}} \mathrm{P}--\overline{\mathrm{P}} \mathrm{P}-\frac{\mathrm{P}}{\mathrm{F}} \mathrm{P}-\mathrm{F}_{\mathrm{P}}-\overline{\mathrm{P}} \frac{-}{\mathrm{F}}-\frac{\mathrm{P}}{\mathrm{P}}$

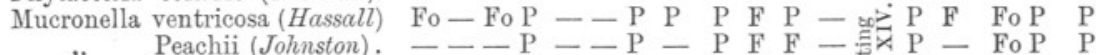
Peachii (Johnston). - - $\mathrm{P}--\mathrm{P}-\mathrm{P} \mathrm{F}-\mathrm{F}-\mathrm{P}-\mathrm{Fo} P \mathrm{P}$
variolosa (Johnston) - $-\mathrm{P}-\mathrm{P}-\mathrm{P} P \mathrm{P}$ ", coccinea... $\quad$... - - $-\mathrm{P}-------\mathrm{C}_{\mathrm{g}}^{\mathrm{g}}-\mathrm{P}-\mathrm{P}$ Palmicellaria Skenei, Ellis \& Sol. - - - - - - - - F F Rhynchopora bispinosa(Johnston)
Cellepora avicularis (Hincks) ... 
Fine sand,

Coarse gravel Fine Shell with sand or mud. gravel. gravel. Stones.

Crisia eburnea (Linn.)

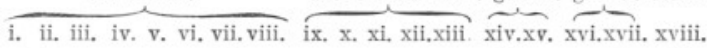

,, ramosa, Harmer $-----F-F-F-F \quad F$ Stomatopora major (Johnston)... - - P - - $-\bar{P}--\overline{\mathrm{P}}-\mathrm{F}-$ , Johnstoni (Heller) granulata (M.Edw.)

Idmonea serpens ( $\operatorname{Linn}$.)

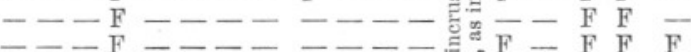
$--\overline{\mathrm{M}} \mathrm{\textrm {M }}-\mathrm{-}-\mathrm{M} \mathrm{P}-\mathrm{P} P-\frac{\mathrm{F}}{\mathrm{P}} \mathrm{F}$ F $\mathrm{F}$ Diastopora suborbicularis, Hnics. - - F - F - F - Fo-

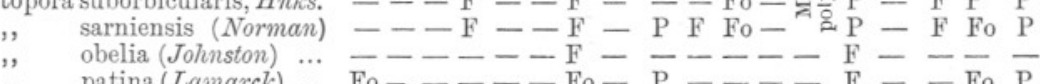

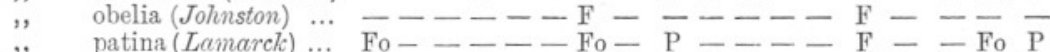
Lichenopora hispida (Fleming) Fo-- P - P P P F F- - P F F P P Alcyonidium gelatinosum (Lin.) - $-\mathrm{F}---\mathrm{Fo} \mathrm{P}-------$ , parasiticum (Flem.) albidum, Alder ....

Cylindroecium dilatatum $(H n k s$.

Pedicellina cernua (Pallas) $\ldots P-P-\mathrm{P}-\mathrm{Fo} P-\mathrm{Fo} P-\bar{P}-\overline{\mathrm{F}}$

L. (?)

B. (?)

L. B. A.L.

Tunicata.

Molgula oculata, Forbes $\quad . .,---------$ Fo --- F -

, simplex, Alder \& Han.. - - - - - F - - - - - - - - - -

Forbesella tesselata (Forbes) ... - - - - - - - - - - - F - - -

Styelopsis grossularia, $\operatorname{Van} B e n . \quad-----------\mathrm{P}-\mathrm{P}-\mathrm{P}_{-}-\mathrm{P}$

Polycarpa varians, Heller $\quad .$. fo $-\ldots-$ - $-\mathrm{M}-\mathrm{M}$ Po Fo $-\mathrm{f} \mathrm{M}--$

Corella larvaeformis, Hancock... - - - - Fo - - - - - - - - -

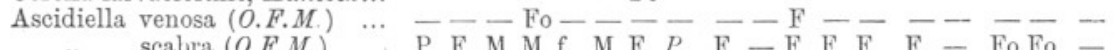

Ascidia depressa, Alder $\quad$... $--\ldots---\cdots---\ldots---c_{-}-\mathrm{F}$

," mentula (O.F.M.) ‥ - - - - - - - - - - - - - - Fo -

Ciona intestinalis $(\operatorname{Linn.}) \quad \cdots+\mathrm{F}----\mathrm{F}---\mathrm{F}-\mathrm{Fo}-\mathrm{P}$ Fo

L.B.

B.

B.

L. B.

B.

L. B.

L. B.

L. B.

L. B.

Cephalochorda.

Amphioxus lanceolatus, Yarrell $-\ldots-\ldots-\ldots-\ldots-\ldots-\ldots$ F F

Fishes.

Pleuronectes platessa, Linn. ... - - F - - - - - - - - - - - - , limanda, Linn. ... microcephalus, Don.

Solea lutea (Risso) ...

,, variegata (Donovan)

Arnoglossus laterna (Walb)

Gadus minutus, Linn.

Merluccius vulgaris (Linn.)

Capros aper (Linn.)...

Zeus faber, Linn. ...

Trigla pini, Bloch ...

,, gurnardus, Linn.

," lineata, Gmel.

hirundo, Linn.

Lophius piscatorius, Linn.

Callionymus lyra, Linn.

Gobius Jeffreysi, Günther

$-\mathrm{M}$ - $\mathrm{M}-\mathrm{M}-\mathrm{M}-\mathrm{-}-\mathrm{-}-\mathrm{-}-\mathrm{-}-\mathrm{-}$

A. B.

A.B.

A.B.

$--\mathrm{Fo}---\ldots-\ldots-\mathrm{L}$.

--- Fo ---------

$\mathrm{M}-\mathrm{M} \mathrm{Fo}-----\cdots-\cdots$

Fo ------------

$\mathrm{Fo}_{\mathrm{P}}----\ldots-\ldots-\ldots$

.. $\quad \mathrm{P}-\mathrm{P}--------\cdots$

… Mo $-\mathrm{P}$ Fo -----------

... F F M $-\mathrm{F}----\cdots----$

... M F M Fo $--\cdots---\cdots--$

... - - Fo MoF - - - - - - - - - -

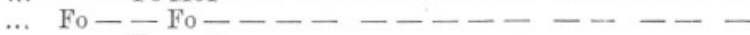

... $-\mathrm{F}-\mathrm{F}--------$

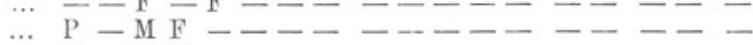

$\mathrm{M}-\mathrm{M} \mathrm{M}-\cdots---\cdots-\cdots-$

Crystallogobius Nilssoni, D.\& K.

Lepadogaster bimaculatus (Don.)

Scyllium canicula (Linn.) $--\mathrm{F}---\frac{-}{\mathrm{F}}-\mathrm{F} \mathrm{F}-\mathrm{F} \mathrm{F}--\overline{-}-\overline{\mathrm{F}_{0}}-$

Raia clavata, Linn....

,, blanda, Holt ...

, sp. (young)

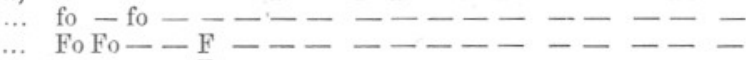

... $----\mathrm{F}----\cdots---$

Rhina squatina (Linn.)

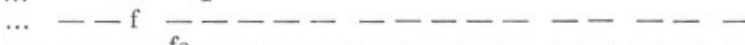

L.

L.

L.

L.

L.

L.

L.B.

L.

L. B.

L.

B.

L.

L. B.

L. 


\section{TABLE VII.}

Showing the number and percentage of animals of each group living at a depth of about 30 fathoms between the Eddystone and Start Point, which are found in the different geographical regions.

\begin{tabular}{|c|c|c|c|c|c|c|}
\hline & $\mid \begin{array}{c}\text { A. L. } \\
\text { Arctic to } \\
\text { Lusitanian }\end{array}$ & $\begin{array}{c}\text { A. B. } \\
\text { Arctic and } \\
\text { Boreal }\end{array}$ & $\begin{array}{c}\text { B. } \\
\text { Boreal }\end{array}$ & $\begin{array}{c}\text { L. B. } \\
\text { Lusitanian } \\
\text { and Boreal }\end{array}$ & Lusitanian & Remarks \\
\hline Foraminifera & 1 & - & - & - & - & $\begin{array}{l}\text { Foraminifera from } \\
\text { bottom - deposits not } \\
\text { included. }\end{array}$ \\
\hline Hydrozoa & $25 \%$ & $\begin{array}{c}4 \\
9 \%\end{array}$ & $\begin{array}{l}17 \\
39 \%\end{array}$ & $\begin{array}{l}6 \\
14\end{array}$ & $\begin{array}{c}6 \\
14 \%\end{array}$ & \\
\hline Anthozoa & - & - & $30 \%$ & - & $70 \%$ & \\
\hline Echinodermata & $\begin{array}{c}3 \\
12 \%\end{array}$ & $\begin{array}{l}3 \\
12 \%\end{array}$ & $\begin{array}{c}5 \\
19 \%\end{array}$ & $\begin{array}{l}12 \\
46 \%\end{array}$ & $\begin{array}{l}3 \\
12 \%\end{array}$ & \\
\hline Nemertina & $\begin{array}{l}3 \\
25 \%\end{array}$ & - & $8 \%$ & - & $\begin{array}{c}8 \\
67 \%\end{array}$ & $\begin{array}{l}\text { Nemertina of northern } \\
\text { seas not well known. }\end{array}$ \\
\hline Polychaete & $\begin{array}{c}6 \\
16 \%\end{array}$ & $\begin{array}{l}6 \\
16 \%\end{array}$ & $13 \%$ & $\begin{array}{l}11 \\
30 \%\end{array}$ & $24 \%$ & \\
\hline Crustacea & $3 \%$ & $\begin{array}{l}3 \\
10 \%\end{array}$ & $\stackrel{3}{3} \%$ & $\begin{array}{l}11 \\
35 \%\end{array}$ & $\begin{array}{l}13 \\
42 \%\end{array}$ & \\
\hline Mollusca & $\stackrel{9}{14} \%$ & $3 \%$ & $10 \%$ & $\begin{array}{l}27 \\
41 \%\end{array}$ & $\begin{array}{l}20 \\
31 \%\end{array}$ & 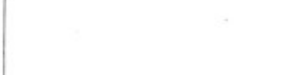 \\
\hline Polyzoa & $\begin{array}{l}19 \\
40 \%\end{array}$ & $\begin{array}{c}4 \\
9 \%\end{array}$ & $\begin{array}{l}8 \\
17 \%\end{array}$ & $\begin{array}{c}4 \\
9 \%\end{array}$ & $\begin{array}{l}12 \\
26 \%\end{array}$ & \\
\hline Tunicata & - & - & $\begin{array}{l}3 \\
33 \%\end{array}$ & $\begin{array}{l}6 \\
67 \%\end{array}$ & - & $\begin{array}{l}\text { Tunicata of northern } \\
\text { seas not well known. }\end{array}$ \\
\hline Fishes & - & $\stackrel{3}{14} \%$ & $\begin{array}{l}1 \\
4 \%\end{array}$ & $\stackrel{3}{14} \%$ & $68 \%$ & $\begin{array}{l}\text { The number of fishes } \\
\text { captured is not large, } \\
\text { as the results are most- } \\
\text { ly those of dredgings. }\end{array}$ \\
\hline Total & $\begin{array}{l}53 \\
18 \%\end{array}$ & $\begin{array}{l}25 \\
8 \%\end{array}$ & $\begin{array}{c}53 \\
18 \%\end{array}$ & $\begin{array}{l}80 \\
26 \%\end{array}$ & $\begin{array}{c}93 \\
30 \%\end{array}$ & \\
\hline
\end{tabular}




\section{LITERATURE.}

1. Agassiz, A.-Echinoidea. Challenger Reports, iii.

2. Allman, G. J.-A Monograph of the Gymnoblastic or Tubularian Hydroids. London Ray. Society, 1871.

3. , Report on the Hydroida. Challenger Reports, xxiii.

4. ", Report on the Hydroida collected during the Expeditions of H.M.S. Porcupine. Trans. Zool. Soc., viii. 1874.

5. Andres, A. Le Attinie. Fauna und Flora des Golfes von Neapel, ix. 1884.

6. Behrens, T. H.-Die Untersuchung der Grundproben. Exped. zur. Untersuch. der Ostsee., 1871. Untersuch. deutsch Meere, i. 1873.

7. Bell, F. Jeffrey.-Catalogue of British Echinoderms in the British Museum (Natural History). 1892.

8. $\quad$ Echinodermata of Green's Deep-sea Cruise. See No. 33. Ann. Mag. Nat. Hist., ser. 6, vol. iv.

9. Bell, Th.-A History of the British Stalk-eyed Crustacea. London. 1853.

10. Bonnier, J.-Catalogue des Crustacés Malacostracés recueillis dans la baie de Concarneau. Bull. Sci. Nord de la France et de la Belgique, xviii. 1887.

11. Bourne, G. C.-Report of a Trawling Cruise in H.M.S. Research off the SouthWest Coast of Ireland. Jour. Mar. Biol. Assoc., N.S. i., 1889-90, p. 306.

12. "Notes on the Hydroids of Plymouth. Jour. Mar. Biol. Assoc., N.S., vol. i. 1889-90, p. 391.

13. Brady, H. B.-Foraminifera. Challenger Reports, ix.

14. Carus, J. V.-Prodromus Faunae Mediterraneae. Stuttgart. 1889-93..

15. Chadwick, H. C.-Report upon the Ophiuroidea. Fauna of Liverpool Bay, vol. i. 1886.

16. " Second Report on the Echinodermata of the L. M. B. C. District. Proceed. Liv. Biol. Soc., iii. 1888-89.

17. Cuénot, L.-Études morphologiques sur les Echinodermes. Archiv. de Biologie, xi., 1891, p. 313.

18. " Contrib. a l'étude anatomique des Astérides. Arch. Zool. Exp. et Gen., $2^{e}$ série, T.V. bis. 1887.

19. Cunningham, J. T., and Ramage, G. A.-The Polychaeta Sedentaria of the Firth of Forth. Trans. Roy. Soc. Edinb., xxxiii. 1887.

20. Dauzenberg, P.-Contribution á la Faune Malacologique des Iles Açores. Résult. Campag. Scient. Prince de Monaco, i. 1889.

21. Dickson, H. N.-Physical Investigations. Journ. Mar. Biol. Assoc., N.S. ii., 1891-92, p. 159 .

22. Forbes, E.-British Starfishes. London. 1841.

23. " Report on the Mollusca and Radiata of the Egean Sea, and on their distribution, considered as bearing on Geology. Report British Assoc., 1843, p. 130.

24. " Report on the Investigation of British Marine Zoology by means of the Dredge. Report Brit. Assoc. 1850.

25. Forbes, E., and Hanley, S.-A History of British Mollusca. London. 1853.

26. Gamble, F. W.-Notes on a Zoological Expedition to Valencia Island, Co. Kerry. Manchester Micr. Soc. Trans. 1895.

27. Garstang, W.-Notes on the Marine Invertebrate Fauna of Plymouth for 1892. Journ. Mar. Biol. Assoc., N.S. ii., 1891-92, p. 333.

28. " Faunistic Notes at Plymouth during 1893-4. Journ. Mar. Biol. Assoc., N.S. iii., 1893-95, p. 210. 
29. Garstang, W.-Contributions to Marine Bionomics, ii., Journ. Mar. Biol. Assoc., iv., 1897, p. 396.

30. Gosse, P. H.-A History of the British Sea-Anemones and Corals. London. 1860.

31. Gourret, P.-Révision des Crustacés Podophthalmes du Golfe de Marseille. Ann. Mus. d'Hist. Nat. Marseille, iii. 1888.

32. Greef, R.-Echinodermen, beobactet auf einer Reise nach der Guinea-Insel São Thomé. Zool. Anzeiger, v. 1882.

33. Green, W. S.-Report of a Deep-sea Trawling Cruise off the S.W. Coast of Ireland, under the direction of the Rev. W. Spotswood Green. Ann. Mag. Nat. Hist., ser. 6, vol. iv. 1889.

34. Haddon, A. C.-First Report on the Marine Fauna of the South-West of Ireland. Proceed. Roy. Irish Acad., 2nd ser., iv., No. 5. 1886.

35. Haddon, A. C., and Shackleton, A. M.-A Revision of the British Actiniae. Parts I. and II. Sci. Trans. Roy. Dublin Soc., vol. iv. (series ii.) 1889 and 1891.

36. Hansen, G. Armauer-Annelida. Norwegian North Atlantic Expedition. 1876-1878.

37. Harmer, S. F.-Note on New or Rare British Marine Polyzoa. Journ. Mar. Biol. Assoc., N.S.V., p. 51.1897.

38. Hartlaub, C.-Die Coelenteraten Helgolands. Wissensch. Meeresuntersuch, i., 1894.

39. Heincke, Fr.-Die Mollusken Helgolands. Wissensch. Meeresuntersuch, i., 1894.

40. Herdman, W. A.-Proceedings and Transactions of the Liverpool Biological Society. Various papers and reports. Vols. i.-xii. 1887-1898.

41. $\quad \quad \quad$ Fauna of Liverpool Bay, vol. i. 1886.

42. $" \quad$ Presidential Address to Biological Section. Report British Assoc. 1895.

43. Herdman, W. A, and Leslie.-The Invertebrate Fauna of the Firth of Forth. 1881.

44. Herdman, W. A., and Lomas, J.-On the Floor Deposits of the Irish Sea. Proceed. Liverpool Geological Society, 1897-98, p. 205.

45. Hickson, S. J.-The Anatomy of Alcyonium digitatum. Quart. Journ. Micr. Sci., xxxvii., 1895, p. 343.

46. Hincks, T.-A History of the British Hydroid Zoophytes. London. 1868.

47. Hodge, G.-On a new Sand Star of the genus Ophiura (Ophiura Normani) found on the coast of Northumberland and Durham. Trans. Tyneside Nat. Field Club, v. 1863.

48. Holt, E. W. L. Survey of Fishing Grounds, West Coast of Ireland, 1890-1891. Sci. Proceed. Roy. Dublin \&oc. 1892.

49. Hornell, J.-Report on the Polychaetous Annelids of the L. M. B. C. District. Trans. Liv. Biol. Soc., v. 1890-91.

50. Hoyle, W. E--Report on the Ophiuroidea of the Faröe Channel, mainly collected by H.M.S. Triton in August, 1882, with some Remarks on the Distribution of the Order. Proceed. Roy. Soc. Edinburgh, 1883-84.

51. $" \quad$ A Revised List of British Ophiuroidea. Proceed. Roy. Phys. Soc. Edinburgh, viii. 1885.

52. $" \quad$ Report on the Biological Investigations on the Sea to the West of Lewis during July and August. Sixth Ann. Report Fishery Board for Scotland. 1887.

53.,$\quad$ On the Deep-water Fauna of the Clyde Sea-area. Journ. Linnean Soc. Zoology, xx. 1889.

54. Hunt, A. R.-On the Influence of Wave-currents on the Fauna inhabiting Shallow Seas. Trans. Linnean Soc., xviii, 1884, p. 262. 
55. Jeffreys, J. Gwyn. - British Conchology. London. 1863-67.

56. Johnston, G.-A History of the British Zoophytes. Edinburgh. 1838.

57. Joly, J., and Dixon, H. H.-Coccoliths in our Coastal Waters. Nature, vol. 56, 1897, p. 468.

58. Kirchenpauer.-Zoologische Ergebnisse der Nordseefahrt (Pommerania) VI. Bryozoa. Jahresber der Comm. zur wiss. Untersuch, d. deutsch. Meere, ii., 1872, p. 173.

59. Koch, G. v.-Die Gorgoniden des Golfes von Neapel. Fauna und Flora des Golfes von Neapel. XV. Monographie. 1887.

60. Koehler, R.-Echinides et Ophiures provenant des campagnes du yacht l'Hirondelle. Result. Camp. Sci. Prince de Monaco, xii. 1898.

61. " Résultats scientifiques de la campagnes du Caudan dans le Golfe de Gascogne, 1895. Annales de l'Université de Lyon.

62. Kowalevsky et Marion.-Contributions a l'Histoire des Solenogastres ou Aplacophores. Ann. Mus. d'Hist. Nat. Marseille, iii. 1887.

63. Lacaze-Duthier, de.-Faune du Golfe du Lion. Coralliaires zoanthaires sclérodermés. Arch. Zool. Exp. et Gen., v. 1897.

64. Laffuie, J. Joyeux.-Description du Delagia chaetopteri (J. J.-L.) Archiv. Zool. Expér. et Gén., vi. 1888.

65. „ Etude Monographique du chétoptère (Chaetopterus variopedatus, Rénier). Archiv. Zool. Expér. et Gén., viii. 1890.

66. Levinsen, G. M. R.-Annulata, Hydroidae, Anthozoa, Porifera. Det Videnskabelige Udbytte af Kanonbaden "Hauchs" Togter. Copenhagen. 1889-93.

67. $\quad$ Polyzoa. Det Videnskabelige Udbytte af Kanonbaden "Hauchs" Togter. Copenhagen. 1889-93.

68. Lo Bianco, Salvatore.-Notizie biologiche riguardanti specialmente il periodo di maturità sessuale degli animali del golfo di Napoli. Mitt. Zool. Sta. Neapel, viii. 1888.

69. Locard, A.-Expéditions scientifiques du Travailleur et du Talisman. Mollusca. Paris. 1897-8.

70. Ludwig.-Die Seesterne des Mittelmeeres. Fauna $u$. Flora des Golfes von Neapel. 24 Monogr. 1897.

71. Lyman, T.-Ophiuroidea. Challenger Report, v.

72. Malmgren, A. J.-Annulata polychaeta Spitsbergiae, Grönlandiae, Islandiae et Scandinaviae hactenus cognita. Öfer. Kgl. Veten. Akad. Förhand. 1867. No. 4

73. Marion, A. F., et Bobretzky._Étude des Annélides du Golfe de Marseille. Ann. Sci. Nat. 6me Sér. Zoologie, ii., 1875, p. 1.

74. Marion, A. F.-Esquisse d'une Topographie Zoologique du Golfe de Marseille. Ann. Mus. d'Hist. Nat. Marseille, i., 1883.

75. Meinert, Th.-Crustacea malacostraca. Det Videnskabelige Udbytte af Kanonbaden "Hauch" Togter. Copenhagen. 1889-93.

76. Meissner, M., and Collin, A.-Beiträge zur Fauna der südöstlichen und östlichen Nordsee. II. Echinodermen. Wissensch. Meeresuntersuch, i. 1894.

77. Metzger, A.-Zoologische Ergebnisse der Nordseefahrt (Pommerania). VIII. Mollusca. Jahresber. der Comm. z. wiss Untersuch, d. deutsch. Meere, ii., 1872, p. 229.

78. $\quad$ Ditto. X. Crustacea.

79. Michaelsen, W.-Die Polychaeten fauna der deutschen Meere. Wiss, Meeresuntersuch, ii., p. 4.

80. Milne-Edwards, A., and Bouvier.-Crustacés décapodes provenant des campagnes du yacht l'Hirondelle. I. Brachyures et Anomoures. Résult. Campag. Scient. Prince de Monaco, vii. 1894. 
81. M'Intosh, W. C.-Report on the Annelids dredged off the Shetland Islands by Mr. Gwyn Jeffreys. Brit. Assoc. Rep. 1868.

82. $\quad$ On the Annelida of the Porcupine Expeditions of 1869 and 1870. Trans. Zool. Soc. London, ix,

83. $" \quad$ On the Annelida obtained during the cruise of H.M.S. Valorous to Davis Strait in 1875. Trans. Linn. Soc. Lond., series 2 , vol. i.

84. $\quad \quad$ On British Annelida. Trans. Zool. Soc., ix. 1876.

85. $\quad$ Annelida Polychaeta. Challenger Report, xii.

86. Möbius, K.-Die wirbellosen Thiere der Ostsee. Untersuch. Deutsch. Meere, i., 1871.

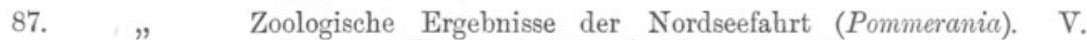
Vermes. Untersuch. Deutsch. Meere., ii., 1875, p. 153.

88. Möbius, K., and Bütschli, O.-Zoologische Ergebnisse der Nordseefahrt (Pommerania). IV. Echinodermata. Untersuch. Deutsch. Meere., ii., 1875, p. 143.

89. Moseley, H. N.-Corals. Challenger Reports, ii.

90. Norman, A. M.-Last Report on Dredging among the Shetland Isles. British Assoc. Reports, 1868, p. 247.

91.,$\quad$ Revision of British Mollusca (Nudibranchiata). Ann. Mag. Nat. Hist., July, 1890, p. 70.

92. $" \quad$ Holothuria nigra, Gray, and its Synonymy. Ann. Mag. Nat. Hist., ser. 6, vol. xii., 1893, p. 409.

93. $\quad$ A Month on the Trondhjem Fiord. Ann. Mag. Nat. Hist., xii. and xiii., 1893 and 1894.

94. Perrier, E.-Contribution à l'étude des Stellérides de l'Atlantique Nord. Result. Camp. Sci. Prince de Monaco, xi. 1896.

95. Petersen, C. G. J.-Det Videnskabelige Udbytte af Kanonbaden "Hauchs" Togter. Copenhagen, 1889-93.

96. Pocock, R. I.-Crustacea. Green's Trawling Cruise. See No. 33.

97. Pruvot, G.-Sur l'organisation de quelques Néoméniens des Cotes de France. Arch.Zool. Expér. et Gén., ix., 1891, p. 699.

98. $\quad$ Essai sur les Fonds et la Faune de la Manche Occidentale comparés a ceux du Golfe du Lion. Arch. Zool. Expér. et Gén., v. 1897.

99. Roule, L.-Recherches sur les Ascidies simples des Cotes de Provence. Ann. Mus. d' Hist. Nat. Marseille, ii. 1884.

100. " Coelentérés. Result. Sci. de la Camp. du "Caudan." 1896.

101. " " Annélides. Result. Sci. de la Camp. du "Caudan," iii., 1896.

102. Saint-Joseph, le Baron de.-Les Annélides Polychètes des cotes de Dinard.

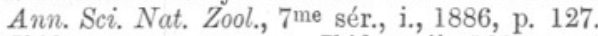
Ibid., v., 1888, p. 141. Ibid., xvii., 1894, p. 1. Ibid., xx., 1895, p. 185.

103.

Les Annélides Polychètes des cotes de France (Manche et Océan). Ann. Sci. Nat. Zool., 8me sér., v., 1898, p. 209.

104. Schiemenz, P.-Wie öffnen die Seesterne Austern? Mitth. Deutsch. Seefisch. verein, $B d$. xii., No. 6, 1896. English translation Journ. Mar. Biol. Assoc., iv. 1895-97.

105. Schulze, F. E.-Zoologische Ergebnisse der Nordseefahrt (Pommerania). III. Coelenteraten. Jahresber. der Comm. zur wiss. Untersuch, d. deutsch. Meere., ii., 1872, p. 121.

106. Sladen, W. P.-Asteroidea. Challenger Report, xxx.

107. Smith, E. A.-Lamellibranchiata. Challenger Report, xiii.

108. Studer, Th.-Beiträge zur Meeresfauna West-Africas. Zool. Anzeiger, v. 1882.

109. Traustedt, M. P. A.-Ascidiae simplices. Det Videnskabelige Udbytte af Kanonbaden "Hauchs" Togter. Copenhagen. 1889-93. 
110. Walther, J.-Einleitung in die Geologie als historische Wissenschaft. I. Theil. Bionomie des Meeres. Jena. 1893-94.

111. Walker, A. O.-Reports on the Higher Crustacea of the L. M. B. C. District. Fauna of Liverpool Bay, i., 1886. Proceed. Biol. Soc. L'pool., ii., 1888. Litto, iii., 1889. Ditto, iv., 1890.

112. " Revision of the Podophthalmata and Cumacea of Liverpool Bay. Proceed. Biol. Soc. L'pool., vi. 1892.

\section{EXPLANATION OF CHARTS}

\section{Illustrating the Report "On the Fauna and Bottom-deposits near the Thirty-fathom line from the Eddystone Grounds to Start Point."}

Conventional signs have been adopted to indicate the texture of the bottom-deposits.

Each species is indicated by a letter, and the kind of type shows the relative abundance of the species. A thick capital placed on any ground indicates that the species is very abundant on the ground; a hollow capital that it is moderately plentiful; a thin capital that it is generally present but only in small numbers; and a small letter that only one or two occasional stray specimens have been taken on the ground.

Chart I.

Alcyonium digitatum.

Caryophyllia Smithii.

Sarcodictyon catenata.

Epizoanthus incrustatus.

Chondractinia digitata.

Chart II.

Halecium halecinum.

Sertularella Gayi.

Aglaophenia myriophyllum.

Sertularia abietina.

Chart III.

Eudendrium ramosum.

" rameum.

Bougainvillia ramosa.

Hydrallmania falcata.

\section{Chart IV.}

Antennularia antennina.

Antennularia ramosa.

Thuiaria articulata.

Plumularia Catharina.

Chart V.

Echinus esculentus.

$$
\text { , acutus. }
$$

" miliaris.

Spatangus purpureus.

Echinocardium cordatum.

Chart VI.

Asterias glacialis.

, rubens.

Holothuria nigra.
Solaster papposus.

Amphiura elegans.

$$
\text { , filiformis. }
$$

Chart VII.

Palmipes placenta.

Luidia Sarsii.

Porania pulvillus.

Henricia sanguinolenta.

Chart VIII.

Astropecten irregularis.

Ophiura ciliaris.

Ophiothrix fragilis.

Ophiocoma nigra.

Chart IX.

Ophiactis Balli.

Ophiura albida.

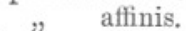

Proneomenia aglaopheniae.

Dondersia banyulensis.

$$
\text { Chart X. }
$$

Chaetopterus variopedatus.

Polygordius sp.

Hyalinoecia tubicola.

Aphrodite aculeata.

Chart XI.

Stenorhynchus longirostris.

Inachus dorsettensis.

Hyas coarctatus.

Ebalia tumefacta.

" tuberosa.

" Cranchii. 
Chart XII.

Pandalus brevirostris.

Eupagurus Bernhardus.

, $\quad$ Prideauxii.

Sagartia parasitica.

Chart XIII.

Atelecyclus heterodon.

Corystes cassivelaunus.

Gonoplax angulata.

Portunus depurator.

$$
\text { , pusillus. }
$$

Chart XIV.

Pecten opercularis.

, maximus.

Cardium norvegicum.
Cardium echinatum (shells).

, ,$\quad$ (living).

Chart XV.

Pectunculus glycimeris.

Fusus islandicus.

Buccinum undatum.

Dentalium entalis.

Turritella communis.

Lima Loscombii.

Chart XVI.

Cellaria fistulosa and sinuosa. Ascidiella scabra.

Polycarpa varians.

Amphioxus lanceolatus.

Lepadogaster bimaculatus. 


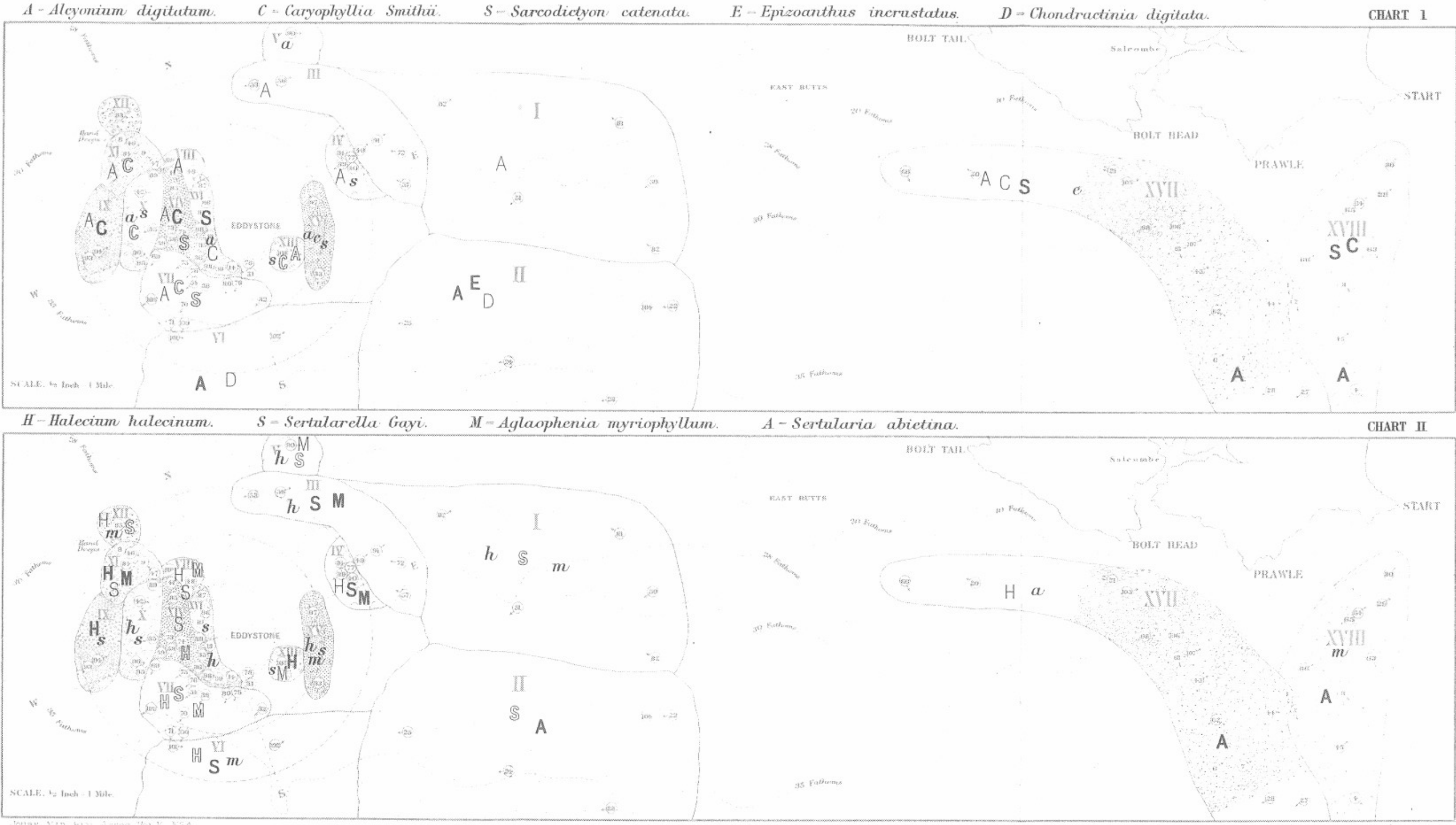




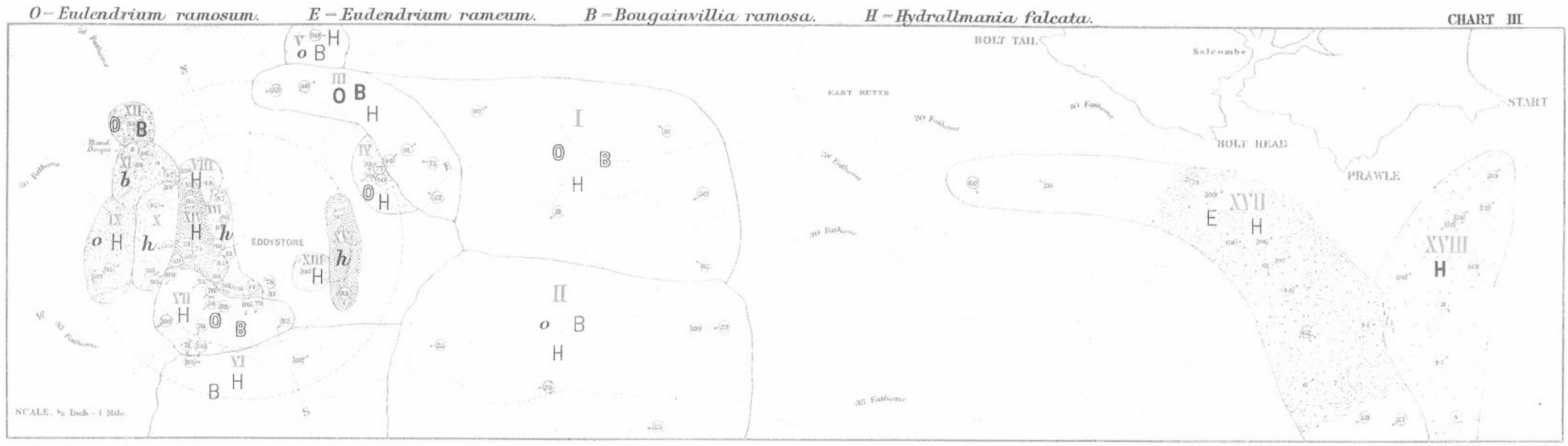

$A$-Antenularia antennina. $\quad R$-Antennularia ramosa. $\quad T$-Thuiaria articulata. $P$-Plumularia Catharina.

CHART IV

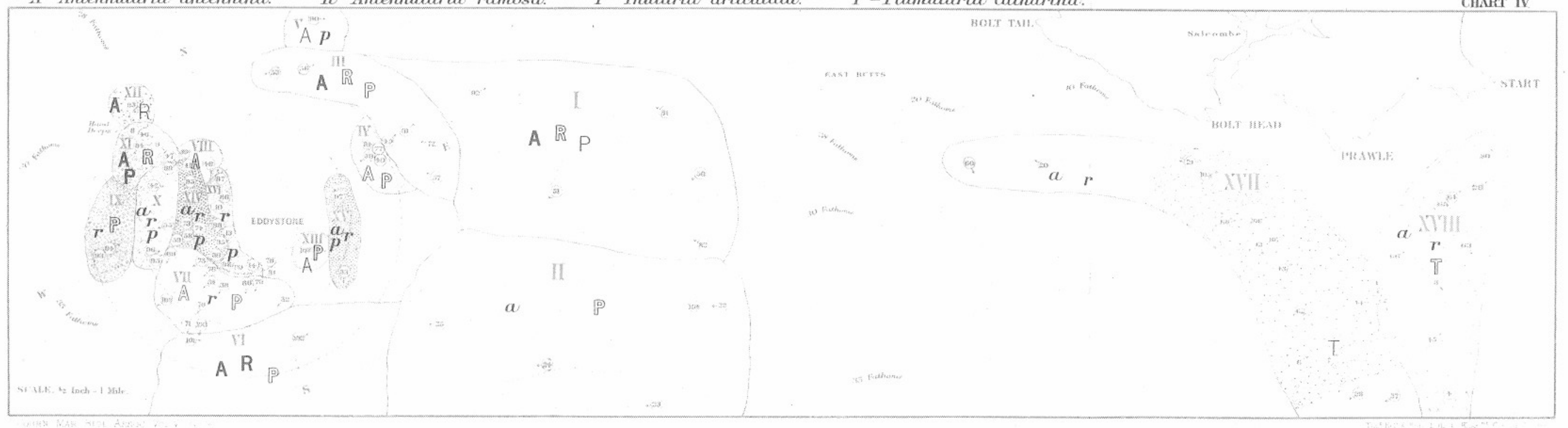




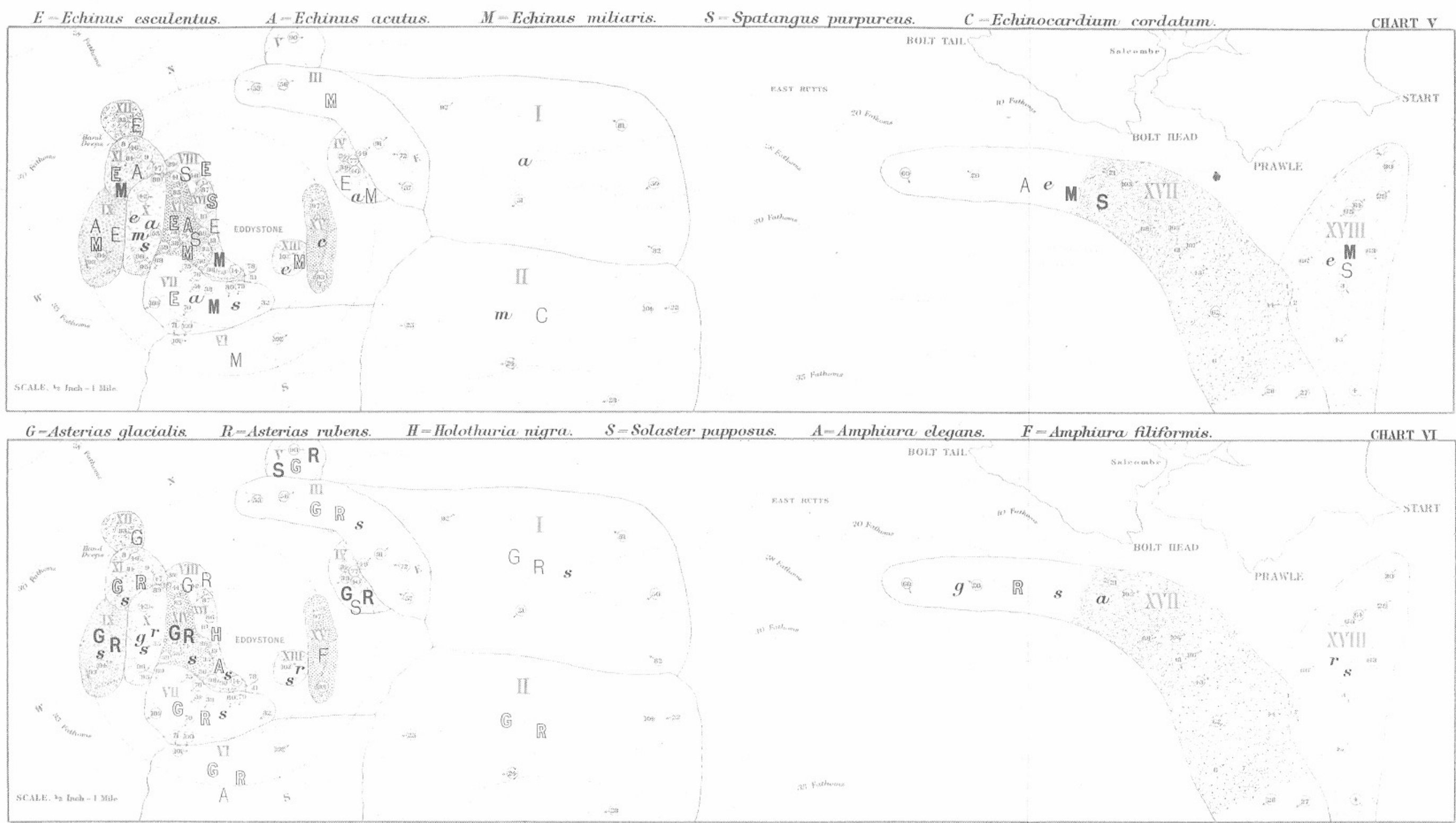



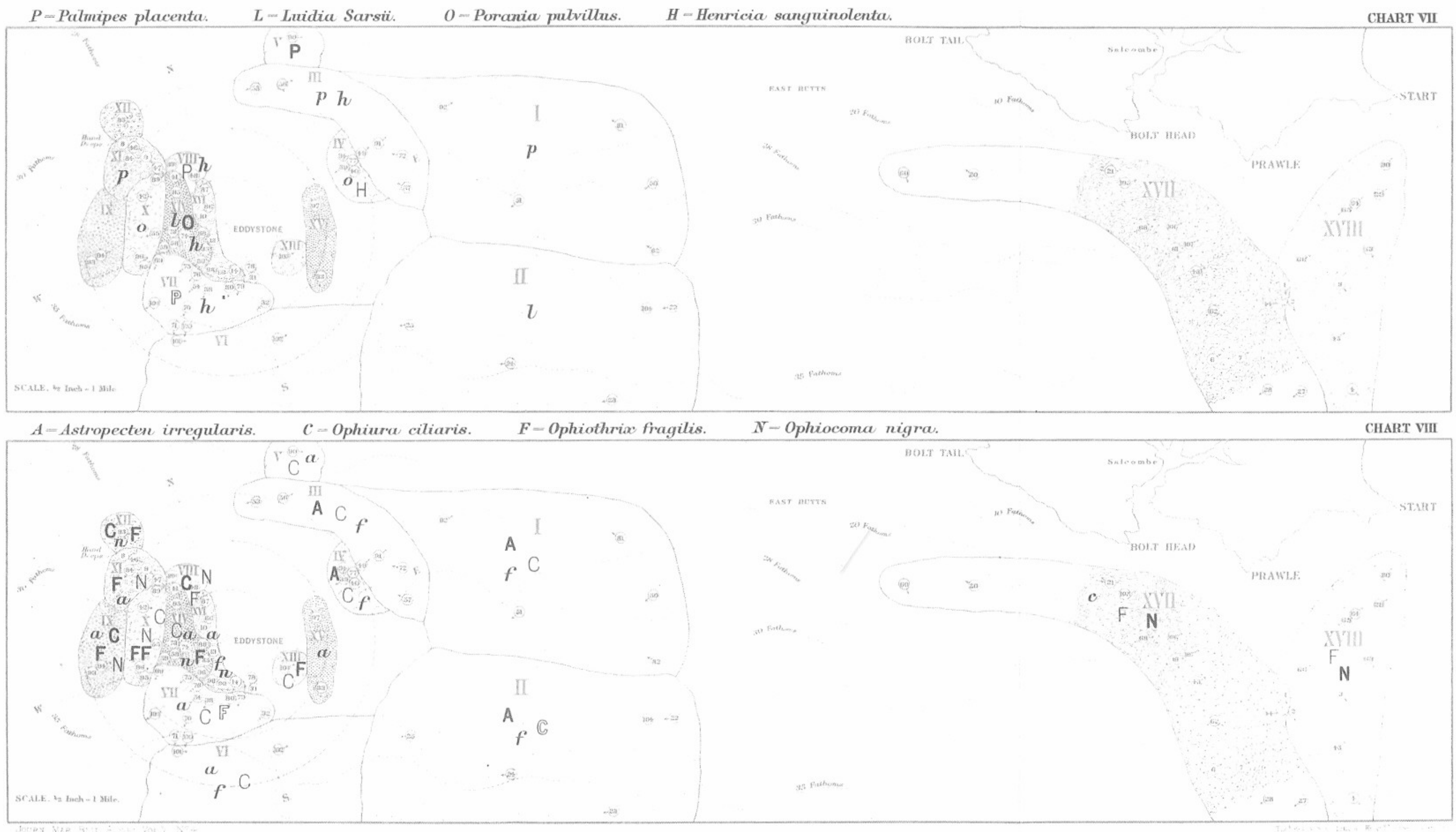


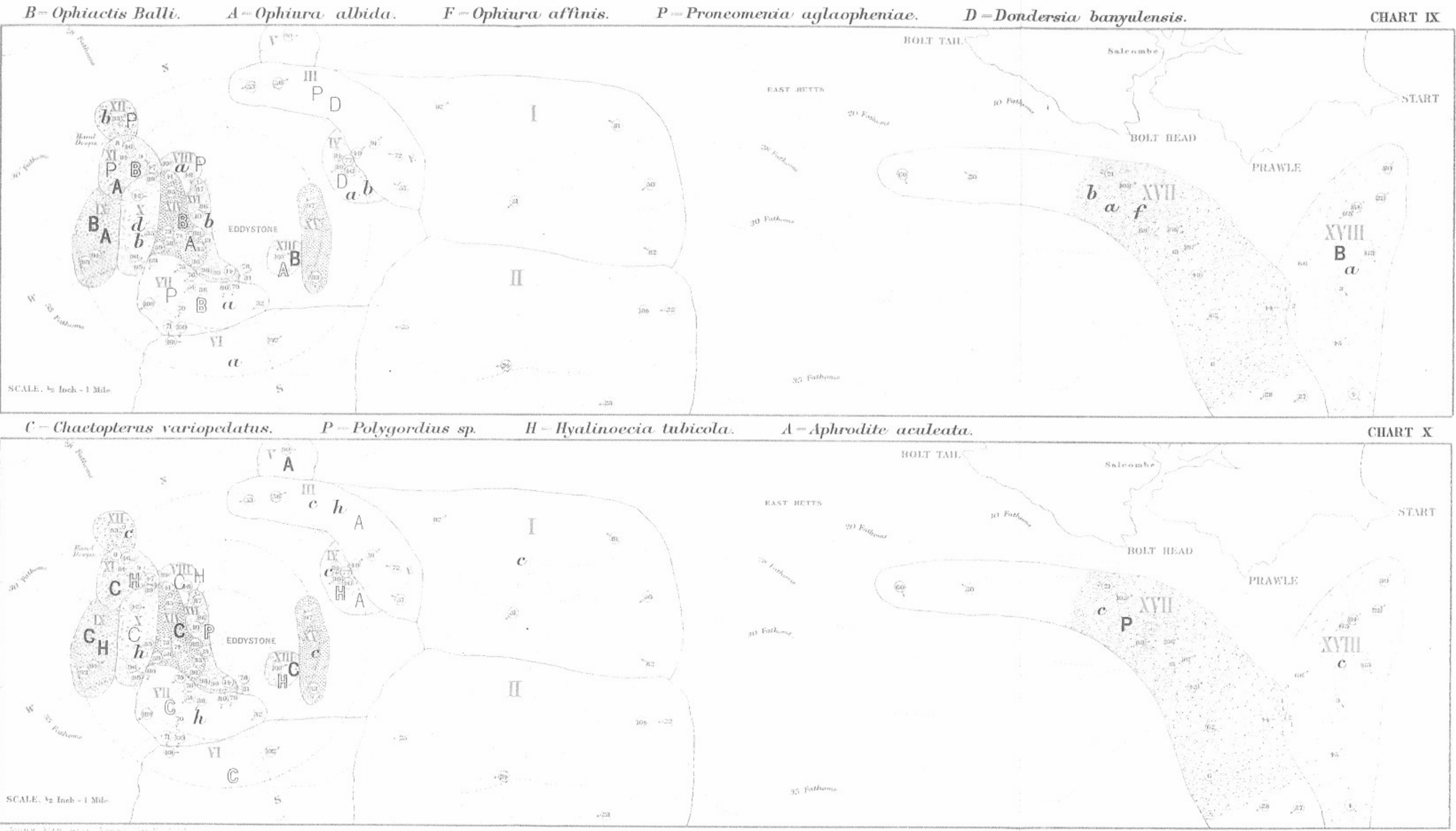


$s$-Stenorhynchus longirostris. I-Inachus dorsettensis.

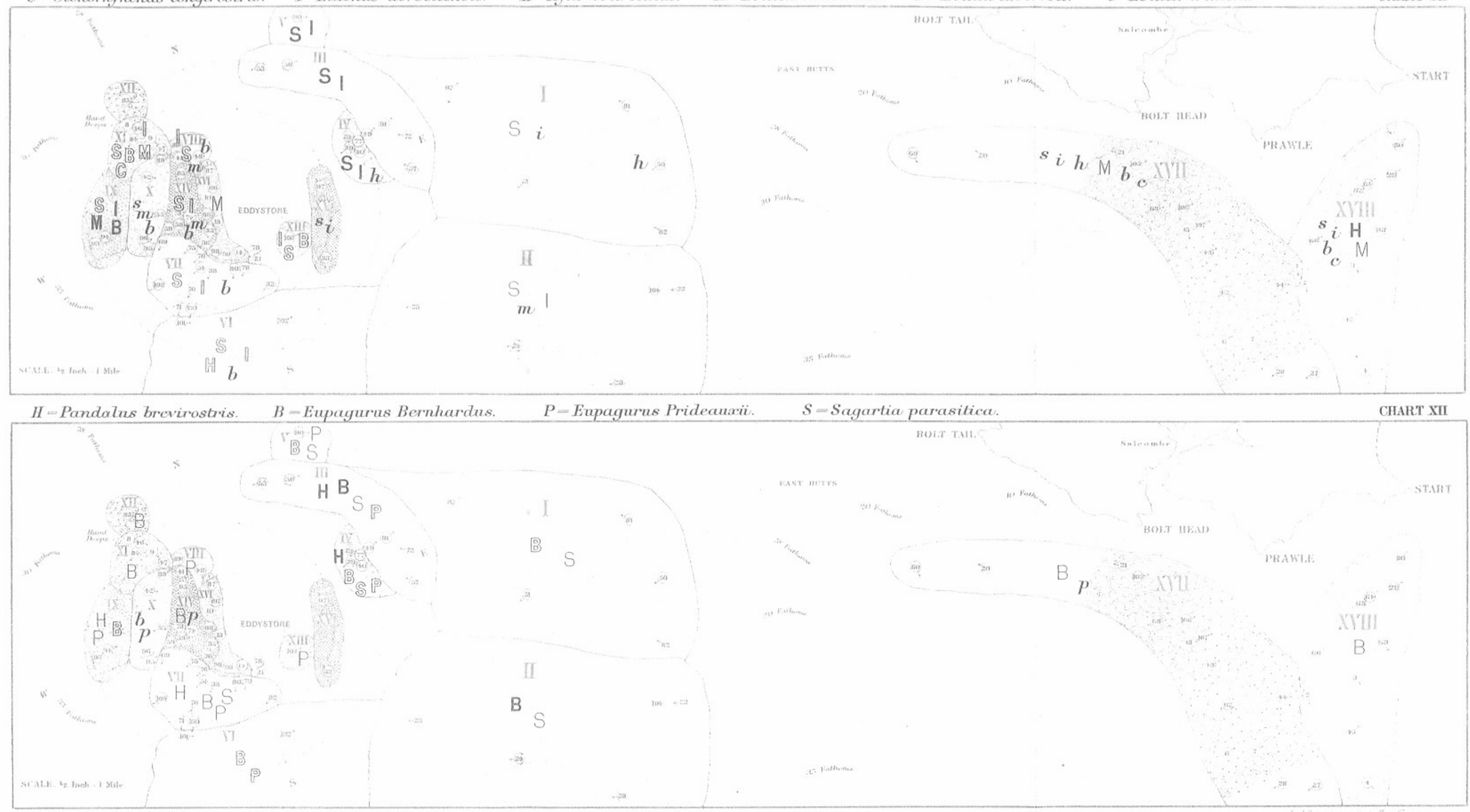




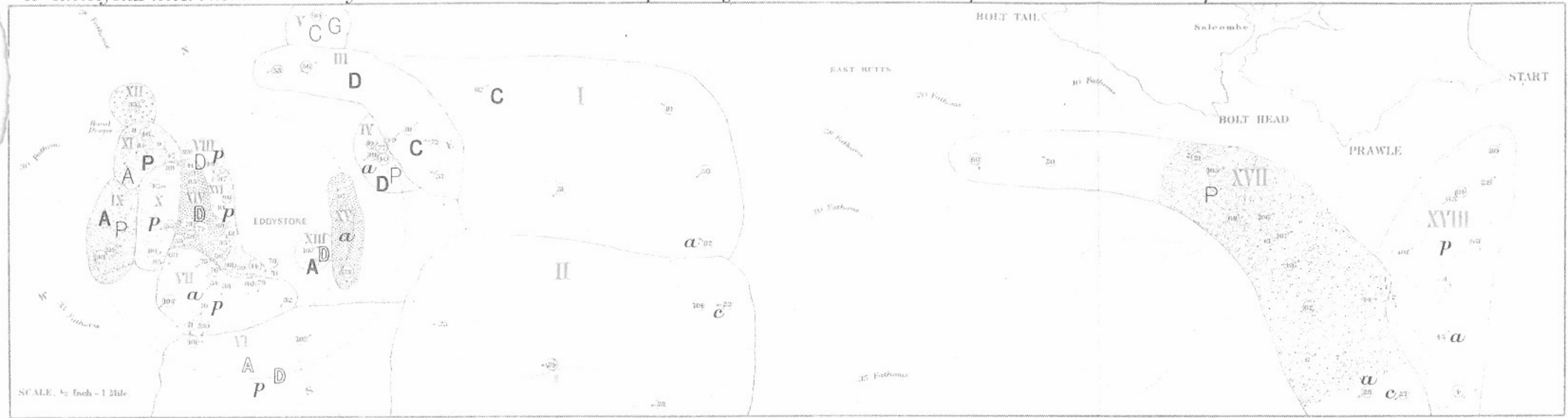

$P$-Pecten opercularis.

$M=$ Pecten maximus

$N=$ Cardium norvegicam.

$E=$ Cardium echinatum.(shells)

$L=$ Cardium echinatum (living)

CHART XIV

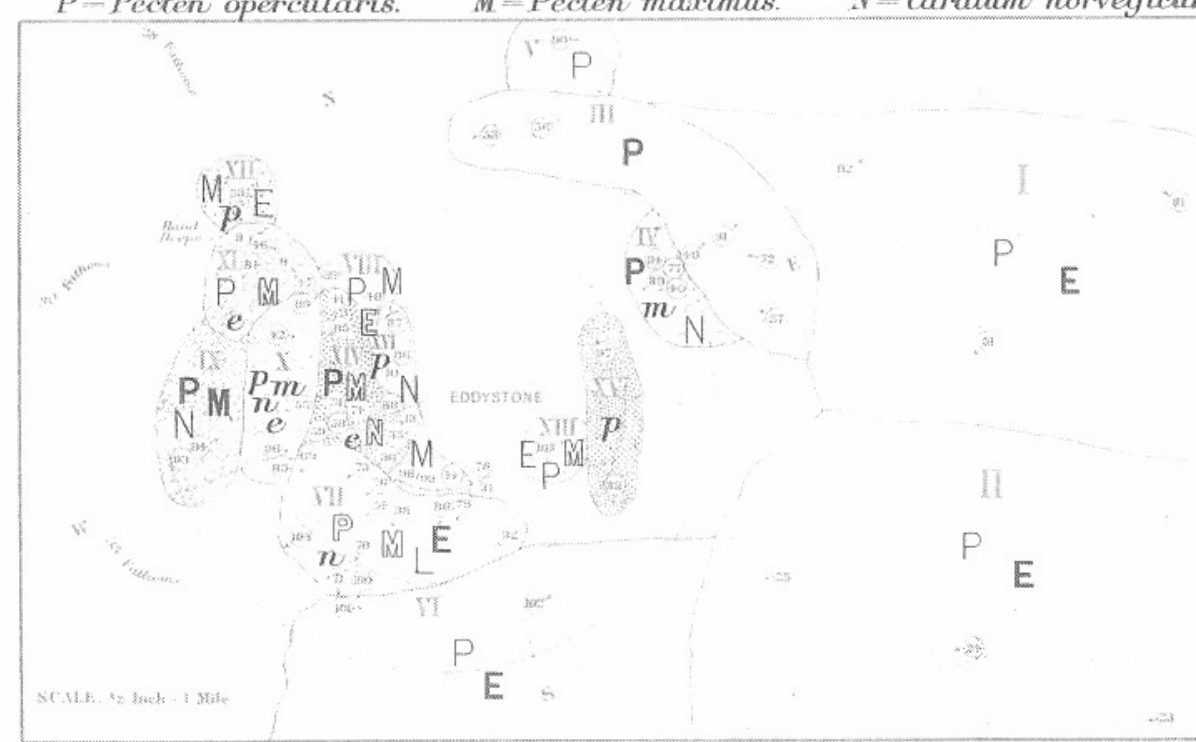




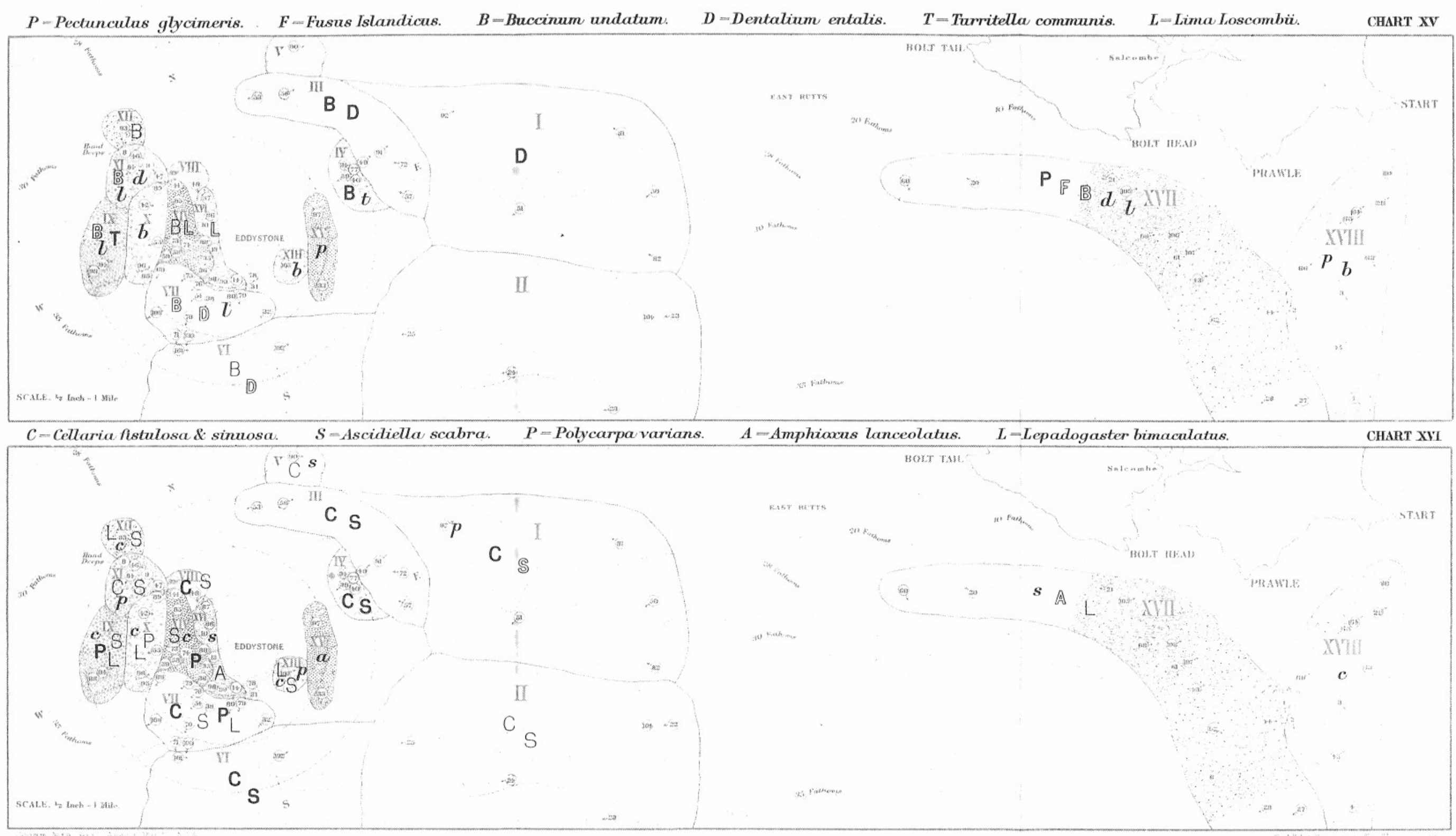

